\title{
AVALIAÇÃO DA INFILTRAÇÃO MARGINAL EM CAVIDADES DE CLASSE II RESTAURADAS COM RESINA COMPOSTA ASSOCIADA A OUTROS MATERIAIS DE INSERÇÃO DIRETA
}

\section{ADRIANO LIA MONDELLI}

Dissertação apresentada à Faculdade de Odontologia de Bauru, da Universidade de São Paulo, como parte dos requisitos para obtenção do título de Mestre em Odontologia, na área de Dentística opção Materiais Dentários. 


\section{AVALIAÇÃO DA INFILTRAÇÃO MARGINAL EM CAVIDADES DE CLASSE II RESTAURADAS COM RESINA COMPOSTA ASSOCIADA A OUTROS MATERIAIS DE INSERÇÃO DIRETA}

\section{ADRIANO LIA MONDELLI}

Dissertação apresentada à Faculdade de Odontologia de Bauru, da Universidade de São Paulo, como parte dos requisitos para obtenção do título de Mestre em Odontologia, na área de Dentística opção Materiais Dentários.

(Edição Revista)

Orientador: Prof. Dr. Áquira Ishikiriama 
Mondelli, Adriano Lia

M745a Avaliação da infiltração marginal em cavidades de classe II restauradas com resina composta associada a outros materiais de inserção direta / Adriano Lia Mondelli.-- Bauru, 1999.

226p. : il. ; 29,7 cm.

Dissertação. (Mestrado) -- Faculdade de Odontologia de Bauru. USP.

Orientador: Prof. Dr. Aquira Ishikiriama

Autorizo, exclusivamente para fins acadêmicos e científicos, a reprodução total ou parcial desta dissertação/tese, por processos fotocopiadores e/ou meios eletrônicos.

Assinatura do autor:

Data: 


\section{Adriano Lia Mondelli}

Nascimento

Filiação

$1992-1996$

1997-1999

1998-1999

Associação
04 de dezembro de 1972

Araraquara - SP

José Mondelli

Marisa Lia Mondelli

Curso de Odontologia - Universidade de Marília - Unimar, Marília - SP.

Curso de Pós-graduação em Dentística opção Materiais Dentários, em nível de Mestrado, na Faculdade de Odontologia de Bauru.

Curso de aperfeiçoamento em Ortodontia preventiva e interceptiva, I e II, Funcraf - Centrinho - USP.

CRO - Conselho Regional de Odontologia - Secção do São Paulo 
AGRADECIMENTOS ESPECIAIS 


\title{
AGRADECIMENTOS ESPECIAIS
}

\author{
A 0 Prof. Dr. Áquira Inshikiriama,
}

meu obrigado por tudo.

brigado por além de orientador, ter sido

amigo; exemplo de dedicação à profissão, e alicerce no qual me apoiei. Por ter sido aquele que mesmo sabendo das minhas limitações, acreditou na minha vontade e dedicação.

A duas pessoas que me incentivaram inúmeras vezes nesse longo

tempo. Verdadeiros Pais, os quais dedico todo esse trabalho e essa conquista, sem nunca pedir nada em troca, mostraram com humildade os melhores caminhos... e características que uma pessoa pode ter, a humildade e honestidade.

Ao meu Pai José Mondelli e minha querida Mãe Marisa Lia Mondelli A gradeço ainda ao Prof. Marcelo A. Pereira, amigo que me ajudou muito na conclusão desse trabalho. Obrigado a todos... 


\section{DEDICATÓRIA}




\title{
DEDICATÓRIA
}

\section{A spessoas que mais dou valor eA mo}

\author{
em minha vida ....
}

A | esus...

\author{
A 0 meu pai e minha mãe,
}

duas pessoas que nunca mediram esforços

para que este sonho se realizasse.

A $0 S$ meus irmãos, Ricardo e Alessandro e

com muito carinho a meu irmão Cirurgião-Dentísta, Rafael os quais agradeço por também fazerem parte da minha vida,

pois sem a influência deles isto não seria realidade.

E a minha namorada $C$ ris, que tanto me apoiou

para concretização desse trabalho

dedico esta conquista 
AGRADECIMENTOS 


\section{AGRADECIMENTOS}

Agradeço também,

À Faculdade de Odontologia de Bauru - USP.

Ao Prof. Dr. Luiz Fernando Pegoraro, atual Presidente da PósGraduação e seu vice-presidente, Prof. Dr. José Carlos Pereira, que nos orientaram adequadamente durante todo o curso.

Ao Departamento de Materiais Dentários e a seus professores sempre prestativos.

Ao Departamento de Dentística e a todos seus professores pelo exemplo de dedicação e competência na área de pesquisa.

Ao meu estimado Prof. Dr. César Antunes de Freitas, pessoa sem a qual isto não seria possível. Agradeço em especial pela tão útil aula de fotografia.

Ao Prof. Dr. Ricardo Marins de Carvalho, meu reconhecimento pela sua competência e visão de pesquisador.

Ao Prof. Dr. José Roberto P. Lauris, pela sua eficiência na elaboração e sugestões na análise estatística. 
Prof. Dr. Adriana Botelho, que auxiliou com muito carinho na elaboração inicial deste trabalho.

Aos Professores Doutores Rubens Carneiro Valera, Mário Honorato Silva e Souza pelo apoio dado.

Ao meu primo Martino Carlo Mondelli, pelo seu esforço, dedicação e abdicação de seu tempo com intuito de me ajudar.

Aos meus parceiros de curso de Ortodontia: Sérgio Azevedo e Celso Tinoco.

Aos meus colegas de consultório, em especial ao amigo Fernando Bichuette, e a minha prima Catarina Mondelli.

À minha auxiliar Déborah que tanto me ajudou na fase laboratorial.

Ana Maria de Araújo Monteiro Xavier, pelo seu apoio na fase final dessa pesquisa.

Aos colegas do curso de Mestrado em Materiais Dentários: Maria Carmen, Cristiane, Júlio e Rodrigo.

A todos meus colegas do curso de mestrado em Dentística, que ajudaram direta ou indiretamente neste trabalho. 
Ao colega João Batista de Souza, agradeço à grande ajuda sem a qual este trabalho não teria se concretizado.

À Elisabeth Cariani, pessoa que, mesmo sem o convívio diário, demonstrou extrema dedicação, gostaria não só de agradecer, mas também declarar minha estima e consideração.

A todos os funcionários da FOB e principalmente da Pós-Graduação que, direta ou indiretamente proporcionaram a realização deste trabalho pela estrutura dada.

Aos funcionários do Departamento de Materiais Dentários, em especial, ao Alcides à Sandrinha e a Lô.

A todos funcionários do Departamento de Dentística, em especial à Eloísa, Ângela, Rosa Sitá, Rosa Fernandes, à Zuleica, ao Nelson, ao Júnior e ao Sr. Dito, pessoas que não passaram na minha vida em vão.

À Cybelle e a todos os funcionários da Biblioteca, pela cordialidade e atenção a mim dispensadas.

À CNPQ pelo fomento, proporcionando a realização deste trabalho.

E por último, mas com total respeito e admiração, à Irma Irene, pela sua força, apoio, conselhos, inspirações e ânimo no decorrer deste longo caminho. 


\section{SUMÁRIO}

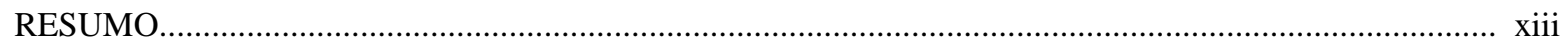

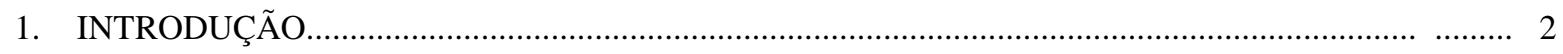

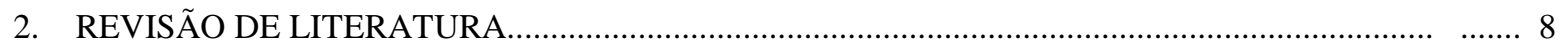

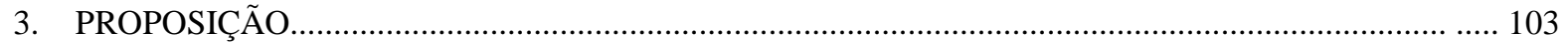

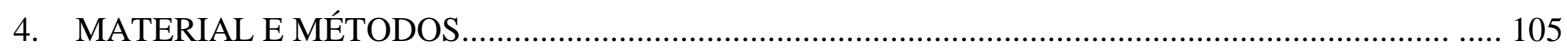

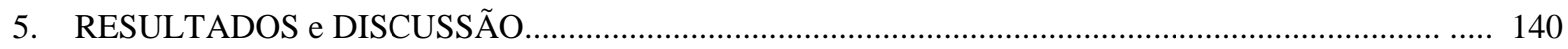

6. CONCLUSÃO

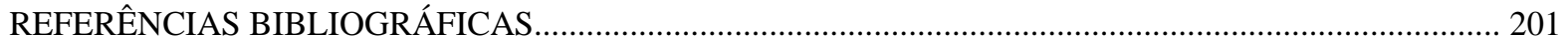

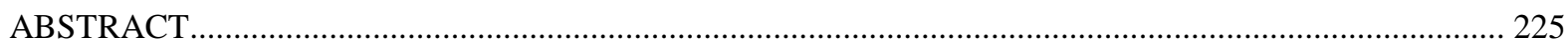


RESUMO 


\section{RESUMO}

As resinas compostas vêm sofrendo inúmeras alterações, com o objetivo de tornar o seu uso adequado para restaurações de dentes posteriores, entretanto, problemas clínicos associados à sua utilização são comumente observados, dentre eles, a microinfiltração marginal. Algumas alternativas clínicas têm sido sugeridas, na tentativa de reduzir as falhas decorrentes do emprego deste material, principalmente em restaurações estendidas à região de cemento, local este onde os problemas se agravaram. O objetivo deste trabalho consistiu, portanto, em estudar a efetividade do vedamento marginal de diferentes materiais aplicados no terço cervical com término em cemento para, em associação à resina composta, restaurar esteticamente cavidades de classe II, através da técnica mista, avaliando-se com esta finalidade $o$ índice de infiltração marginal na interface cemento/material restaurador. Cavidades M.O.D. com margens cervicais estendidas além da junção amelocementária foram confeccionadas em 60 pré-molares humanos livres de cáries, os quais foram distribuídos em grupos de 10 elementos cada, correspondendo a 5 condições experimentais:

Grupo controle - em todos os dentes, Scotchbond MP / Z-100

Grupo 1 - Scotchbond MP (Concise) / Concise / Scotchbond MP / Z-100

Grupo 2 - Alpha Bond / Natural Flow / Scotchbond MP / Z-100

Grupo 3 - One step / Aeliteflo / Scotchbond MP / Z-100

Grupo 4 - Prime \& Bond 2.1 / Dyract-AP / Scotchbond MP / Z-100

Grupo 5 - Verniz copalite / Velvalloy / Scotchbond MP / Z-100

No sentido de evitar penetração da solução corante em áreas indesejadas. Em todos os dentes os forames apicais foram obstruídos com Scotchbond MP / Z-100. Após 48 horas, as restaurações foram polidas com discos Sof-Lex de granulação fina e submetidas posteriormente a um teste de ciclagem por carregamento oclusal correspondendo a 200 ciclos 
de 1 a $17 \mathrm{~kg}$. Imediatamente após a ciclagem, os espécimes foram armazenados 24 horas em água destilada a $37^{0} \mathrm{C}$. Após este período tiveram a superfície totalmente coberta por uma camada de esmalte de unha, exceto $1 \mathrm{~mm}$ aquém e além da interface cemento/ material restaurador. Depois foram termociclados em azul de metileno a $2 \%$ correspondendo a 180 ciclos de 45 segundos cada, nas temperaturas de $5^{0} \mathrm{C}, 37^{0} \mathrm{C}$ e $55^{\circ} \mathrm{C}$. Os corpos de prova foram armazenadas em azul de metileno a $2 \%$ por mais 24 horas a $37^{0} \mathrm{C}$. Decorrido este período os dentes foram incluídos em bases acrílicas apropriadas para serem adaptadas à máquina de corte, obtendo-se cerca de 3 cortes para cada espécime. Para avaliar o índice de penetração da solução corante nas interfaces cemento/material restaurador, optou-se pela análise qualitativa, através da atribuição de escores previamente determinados. Os resultados obtidos foram então organizados e submetidos aos cálculos estatísticos, concluíndo-se que:

- amálgama Velvalloy e a resina composta Z-100 usada como controle apresentaram respectivamente os índices mais severos de infiltração marginal, na interface cemento/material restaurador;

- Houve diferença estatística significante entre o Dyract-AP e os demais materiais testados o qual reduziu consideravelmente o índice de infiltração marginal nas interfaces das restaurações;

- A resina quimicamente ativada Concise e as fluídas Aeliteflo e Natural Flow ocuparam uma posição intermediária com relação à infiltração marginal, com desempenho estatisticamente igual entre si e desfavoravelmente em relação ao Dyract AP; por outro lado, sobressaíram-se positivamente em comparação ao amálgama;

- Não obstante o melhor comportamento apresentado pela resina composta modificada por poliácidos Dyract-AP, observou-se que nenhum material restaurador utilizado foi apto em impedir $100 \%$ a penetração da solução corante nas margens cervicais em cemento 
1 INTRODUÇÃO 


\section{1 - INTRODUÇÃO}

A importância da estética na Odontologia cresce progressivamente. Na sociedade moderna esse aspecto tornou-se essencial e com isso a demanda de pacientes que procuram resultados favoráveis é muito alta, obrigando os profissionais a se atualizarem constantemente em técnicas e materiais. Essa mudança de conceito ocorreu em grande parte pelo marketing dos fabricantes e pela mídia, que aumentaram consideravelmente a exigência em relação à qualidade dos trabalhos. No caso das restaurações, a busca por um material adesivo de inserção direta ou indireta que apresente as mesmas características mecânicas, funcionais e estéticas dos elementos dentários tornou-se um dos principais objetivos.

Desde o início do século, os principais materiais restauradores para dentes posteriores eram o amálgama e o ouro em folha. Com o desenvolvimento das resinas compostas, juntamente com o condicionamento ácido do esmalte, introduzido na prática odontológica por BUONOCORE ${ }^{20}$, a resolução de lesões dentárias por procedimentos operatórios menos invasivos (simples remoção de tecido comprometido) tornou-se viável, uma vez que esse sistema restaurador adesivo reduz ou elimina em algumas situações a necessidade de remoção de estrutura dentária sadia para obter formas de resistência e retenção adequadas 96,133 .

A resina composta, desenvolvida e lançada no comércio odontológico no início dos anos sessenta ${ }^{14}$, foi considerada um material estético revolucionário, superando o que existia na época para restaurar dentes anteriores, como os cimentos de silicato e a resina acrílica ativada quimicamente. Devido a grande aceitação pela classe odontológica e aos resultados 
laboratoriais e clínicos favoráveis na região anterior, não tardou para que seu uso fosse estendido aos dentes posteriores ${ }^{133}$.

No entanto, os primeiros resultados de avaliação clínica na região posterior mostraram as deficiências desse procedimento restaurador em relação ao amálgama, notadamente quanto à resistência ao desgaste e à cárie secundária. PHILLIPS et al. ${ }^{155,156} \mathrm{e}$ OSBORNE et al. ${ }^{147}$ constataram altíssimos índices de desgaste, assim como manchamento marginal e recidiva de cárie, inviabilizando na época seu uso. Contudo, devido a justificativas como a continuação do seu sucesso em dentes anteriores; ao desenvolvimento de composições mais resistentes ao desgaste, pela modificação no tamanho, distribuição e quantidade das partículas inorgânicas ${ }^{111,112}$; a introdução de sistemas adesivos com características hidrofílicas, que permitem a difusão e interação do adesivo com o substrato dentinário (formação da camada híbrida), possibilitando altos índices de adesão à dentina ${ }^{25}$, as restrições ao amálgama e a exigência dos pacientes por um material estético, voltou-se a recomendar novamente o seu uso em dentes posteriores.

Todavia, a obtenção de uma relação de contato satisfatória ${ }^{18,97}$, a sensibilidade técnica dos materiais envolvidos ${ }^{63}, 133,163$, juntamente com a força de contração volumétrica de polimerização e o coeficiente de expansão térmica linear tornam as restaurações adesivas um sistema de uso crítico, especialmente em cavidades que se estendem à superfície proximal de dentes posteriores ${ }^{105,124}$, as quais a infiltração nas interfaces cervicais, principalmente nas que terminam em cemento ${ }^{53,54,160,197,200}$, podem levar à falha precoce. As alterações elásticas dos dentes ou as deformações plásticas sofridas pelas restaurações, principalmente durante a mastigação, são fatores importantes que podem influenciar na infiltração marginal, podendo acarretar rupturas das ligações adesivas 99,116 
É conhecido que a força de contração de polimerização causa tensões na interface dente/restauração ${ }^{40,187}$, contribuindo para a microinfiltração, pois, com o rompimento das ligações adesivas e afastamento do material restaurador das paredes da cavidade, forma-se uma microfenda, a qual permite o ingresso de bactérias e fluidos orais, com conseqüentes hipersensibilidade, pigmentação das margens e reincidência de cáries ${ }^{103}$. O volume do incremento submetido à ação da luz polimerizadora, a intensidade e distância da fonte de luz e o fator de configuração cavitária são aspectos importantes no controle das tensões geradas pela força de contração do sistema restaurador adesivo ${ }^{25,59}$. Quanto menor o volume de material a ser polimerizado e a relação entre o número de superfícies cavitárias aderidas e não aderidas, menores a intensidade e/ou a distância da fonte de luz que retardam a passagem da fase pré-gel para gel e maior a capacidade de relaxamento das tensões oriundas da força de contração de polimerização. Também o emprego de resinas fluidas com menor potencial de gerar forças de contração é outro artifício técnico sugerido para "atapetar" as cavidades a serem restauradas com resinas compostas e, assim, relaxar essas tensões. Inicialmente as resinas fluidas (baixa viscosidade) eram indicadas para o forramento e restaurações de classe $\mathrm{V}$ e, posteriormente, para restaurações de classe II associadas ás resinas compostas "condensáveis", a fim de possibilitar melhor adaptação e conseqüente vedamento marginal.

Um paradigma que ainda mal interpretado e compreendido, porque geralmente não é bem explicado pela literaturados fabricantes: "a menor contração volumétrica determina melhores resultados práticos". Quando é lançado no mercado um novo material à base de resina, é habitual que o fabricante o apresente como aquele que contrai menos. Assim, é comum o cirurgião-dentista escutar do representante ou ler nas informações do fabricante que "a nova resina contrai cerca de $1,8 \%$; isto é, $50 \%$ menos que as outras, que contraem em média 3,6\%". Convém salientar que tais valores oriundos dessas informações sobre contração 
volumétrica servem apenas para vender o produto e não são determinantes de melhores resultados práticos, a não ser nos casos onde não se utilizam técnicas adesivas. Outra falha de interpretação diz respeito ao dogma: “as resinas condensáveis por possuírem maior quantidade de carga, são melhores e contraem menos". Não é correto, porque, quando o material possui maior porcentagem de carga inorgânica, o módulo de elasticidade é maior ( a não ser em cargas com baixo módulo de elasticidade)e o material mais rígido. Materiais rígidos não absorvem forças criadas durante a polimerização, enquanto os mais flexíveis o fazem e, em consequiência, a transmissão de forças até a interface adesiva é menor. Ao aumentar a porcentagem de carga, a resina contrai com mais força, embora em menor índice.

Por essas razões, a porcentagem de contração volumétrica tem pouco valor ou significado prático comparada à força de contração gerada, já que estas forças é que virão competir com as forças de adesão obtidas nas paredes cavitárias pelos processos de condicionamento ácido e aplicação do primer e adesivo.

Estes conceitos constituíram o fundamento básico para o desenvolvimento das resinas fluídas ou de baixa viscosidade que segundo seus fabricantes, possuem um potencial muito bom para evitar a perda de adesões e, conseqüentemente, a formação de microfendas e infiltração marginal. Além disso, segundo esses mesmo fabricantes, elas devem ser usadas como "amortecedores" das forças de contração geradas abaixo das resinas em todas as restaurações de risco. Conclui-se que as resinas fluidas, possuindo baixo módulo de elasticidade mas contração volumétrica alta, gerarão baixas magnitudes de forças durante sua contração de polimerização. Até quanto isso poderá refletir numa interface de melhor qualidade e menor índice de infiltração marginal despertou o interesse para esta investigação, simulando em laboratório condições bem próximas daquelas previstas na clínica pela técnica do "sanduíche". 
Outros materiais também foram sugeridos e testados nessa técnica, como a resina composta quimicamente ativada, o ionômero de vidro, o amálgama e a resina modificada por poliácidos (compômeros), com eficiência aceitável em relação à infiltração marginal, mas sem indicar com precisão qual ou quais deles seriam os mais eficientes. Desse modo, surgem dúvidas, quanto ao material mais efetivo a ser associado às restaurações de classe II M.O.D. de resina composta, pela técnica do "sanduíche" para impedir ou diminuir o índice de infiltração marginal. O compômero seria mais efetivo que o amálgama ou a resina fluida para vedar a interface da parede gengival. E a resina quimicamente ativada, mais eficiente que os materiais citados? Para essas questões não foram encontradas respostas concretas na literatura especializada ou em pesquisas que englobassem marcas comerciais representativas desses materiais, de forma comparativa, a fim de definir qual associação de materiais seria mais eficiente para diminuir ou impedir a infiltração marginal. Foram essas justificativas, que levaram á proposta investigação, ou seja, avaliar qualitativamente "in vitro" a microifiltração marginal na interface cervical de um sistema restaurador adesivo de uso direto, associando-o a outros materiais (técnica mista), submetidos a ciclagens mecânica e térmica. 
2 REVISÃO DE LITERATURA 


\section{2 - REVISÃO DE LITERATURA}

BUONOCORE ${ }^{20}$, em 1955, realizou um estudo na tentativa de aumentar a retenção de materiais restauradores acrílicos à superfície do esmalte, utilizando dois ácidos diferentes. Foram comparados os efeitos dos ácidos fosfo-molibdílico-oxálico e fosfórico a 85\%. O autor concluiu que o uso do ácido fosfórico aumentou e retenção mecânica das resinas acrrílicas ao esmalte dental, sugerindo que este tipo de procedimento possibilitaria a realização de: preparos mais conservadores, utilização de selantes de fóssulas e fissuras com maior secesso, além de uma maior retenção das restaurações de preparos classe III e V.

Em 1965, PICKARD; GAYFORD ${ }^{157}$, desenvolveram um estudo relacionado com a microinfiltração em restaurações de amálgama, tornando-se uma referência sobre o assunto. $\mathrm{O}$ propósito deste foi revisar a literatura a respeito do assunto bem como descrever uma técnica através da qual pudessem avaliar in vitro, quantitativamente, a infiltração marginal nas restaurações de amalgama. Os autores relataram técnicas descritas na literatura que utilizavam ar pressurizado, bactérias, penetração de corantes e isótopos radioativos. Relataram que o método de penetração do corante possui a vantagem de favorecer a avaliação em toda a periferia da restauração, possuindo, porém, a desvantagem de permitir que uma grande infiltração em um determinado ponto nas proximidades marginais possa mascarar uma pequena infiltração na interface adjacente a ele. Um outro fator considerado negativo seria a impossibilidade de avaliar o comportamento de uma mesma amostra em períodos posteriores, por ser esta destruída durante os testes. Os autores avaliaram, ainda, diferentes meios do armazenamento dos espécimes durante o desenvolvimento da pesquisa e concluíram que, para testes de microinfiltração em restaurações de amalgama, o armazenamento em saliva não é 
indicado. Esta possui alta viscosidade e componentes orgânicos e inorgânicos, não presentes em testes laboratoriais. Tais fatores levaram os autores a concluir que, em condições "in vitro”, os produtos de corrosão e depósitos bacterianos da saliva artificial obstruem as vias de penetração do corante, impedindo, assim, uma correta avaliação da capacidade de selamento marginal do material restaurador. Afirmaram, também, que a infiltração é mínima nas restaurações mais antigas de amálgama provavelmente devido ao depósito de produtos de corrosão ou de materiais orgânicos na interface dente/restauração.

Realizando um novo trabalho sobre adesão, BOWEN ${ }^{15}$, em 1967, afirmou que a força adesiva do material restaurador a estrutura dentária deverá ser em todo o momento tão resistente quanto as forças de tracionamento e cisalhamento que possam ocorrer junto a interface das restaurações. Relatou que estas forças podem ser originadas da contração volumétrica sofrida pelo material restaurador, pelas forças externas e em parte pelas diferenças dos coeficientes de expansão térmica dos materiais e estrutura dentária. Os testes "in vitro" que induzem a microinfiltração podem estar clinicamente associados a queda de parte da adesão decorrente das forças geradas durante a mastigação. $\mathrm{O}$ autor avaliou que as forças geradas durante a contração de endurecimento das resinas compostas podem gerar tensões de até 2,4 MPa.

Em 1969, GUZMAN; SWARTZ; PHILLIPS ${ }^{80}$, estudaram o efeito do estresse térmico no vedamento marginal de 4 materiais restauradores ( amálgama, cimento de silicato, resina acrílica, resina composta) em cavidades de classe V . A infiltração marginal foi avaliada em períodos de uma semana, um mês e três meses após a confecção das restaurações . Em cada período de estudo foram utilizados 27 restaurações de cada material, divididas em três grupos, 
onde 9 amostras foram submetidas a 50 ciclos térmicos em água, com banhos de 30 segundos às temperaturas de $15+/-1^{\circ} \mathrm{C}$ e $45+/-1^{\circ} \mathrm{C}$; e as 9 amostras restantes receberam este mesmo tratamento por 500 vezes. Após, os dentes foram imersos em uma solução contendo cloreto de cálcio e a infiltração marginal foi avaliada por autorradiografias. Pelos resultados, o vedamento marginal não foi afetado pelos estresses térmicos aplicados, exceto em um grupo de restaurações de amálgama realizadas sem forramento com verniz, onde houve aumento da microinfiltração, após aplicação de 500 ciclos térmicos em todos os períodos estudados .

Em 1972 WILSON; KENT ${ }^{202}$, preconizaram um novo tipo de cimento odontológico: o cimento de inonômero de vidro, um material translúcido, considerado um híbrido entre os cimentos de policarboxilato e de silicato. Este novo material baseava-se na rápida reação de presa entre partículas do silicato de alumínio com íons liberáveis e copolímeros do ácido acrílico, recebendo o nome genérico de ASPA. Os autores recomendaram este novo material para uso em restaurações de dentes anteriores, restaurações de erosões, como base protetora e para cimentação de restaurações metálicas. Para os autores, o cimento ionomérico, ASPA, apresentou como vantagens em relação ao cimento de silicato uma superfície mais resistente ao ataque por ácidos fracos e ao manchamento, menor irritabilidade pulpar e capacidade de união ao esmalte dental. Segundo os autores o cimento de ionômero de vidro representava um desenvolvimento lógico do cimento de silicato que havia sido até então amplamente usado pelos cirurgiões dentistas, desde a sua invenção nos anos iniciais deste século. O cimento de ionômero de vidro foi considerado um tipo especial de resina composta onde a matriz/partícula se forma durante a reação de presa e se auto-ajustam, tornando-se esses materiais resistentes aos ciclos térmicos e mecânicos. 
A contração de polimerização dos polímeros naturais ou artificiais pode causar dano considerável para superfícies sólidas nas quais são aderidos. Partindo desse princípio, JÖRGENSEN; ASMUSSEN; SHIMOKOBE ${ }^{98}$,em 1975, analisaram sob microscópio de inspeção, defeitos no esmalte (causados pela contração de polimerização) ao redor de cavidades restauradas com resinas compostas quimicamente ativadas. Os dentes foram divididos em três grupos, de acordo com a técnica restauradora utilizada. As restaurações foram feitas sob temperatura constante $\left(37^{\circ} \mathrm{C}\right)$ e durante a análise no microscópio houve variação nessa temperatura. Os resultados mostraram que: $1^{\circ}$ - nas restaurações onde foi executado o condicionamento ácido do esmalte as resinas se mostraram tão efetivamente aderidas ao esmalte das paredes da cavidade que a força de união foi mais alta que a resistência à tração do esmalte, em direção perpendicular aos prismas; $2^{\circ}$ - os estresses de tração presentes nas margens das restaurações foram causados por contração de polimerização, contração térmica e histerese elástica .

JORGENSEN; MATONO; SHIMOKOBE ${ }^{99}$, em 1976, estudaram a deformação de determinados tipos de cavidades, em dentes humanos extraídos sob carga axial e os possíveis efeitos desta deformação na qualidade das restaurações. Dentes com cavidades não restauradas e dentes restaurados foram submetidos a aplicações de forças variando entre 0,5 e $16 \mathrm{~kg}$. A aplicação de carga axial sobre os espécimes foi feita durante 2 minutos com períodos ativos de 5 segundos, alternando com iguais períodos livres. As cavidades vazias demonstraram deformações com o estresse e as cavidades restauradoras exibiram fendas transitórias ou permanentes, após avaliação ao microscópio. Os resultados permitiram concluir que embora a magnitude das forças de fechamento e mastigação sob condições funcionais seja quase desconhecida, a instabilidade dimensional das cavidades vazias 
demonstrada neste estudo, mesmo sob pequenas e moderadas cargas, indica um severo risco de percolação que pode ocorrer com diversos materiais restauradores, causando fraturas de bordas, pequenas fendas e infiltração marginal.

Através de uma revisão de literatura $\mathrm{KIDD}^{103}$, em 1976, abordou a microinfiltração como sendo a passagem de bactérias, fluídos, moléculas, ou íons na interface estrutura dentária/material restaurador. Os problemas como cáries secundárias, descoloração marginal, hipersensibilidade, alterações pulpares e a biocompatibilidade dos materiais são fatores diretamente relacionados com a microinfiltração. Nesse estudo, a autora enfatizou o fato de ainda não existir um material restaurador que seja apto em aderir quimicamente à superfície dentária, proporcionando assim um perfeito selamento marginal, capaz de resistir as mudanças de temperatura e à umidade no interior da cavidade bucal. Várias técnicas têm sido aplicadas com intuito de investigar as propriedades de selamento das restaurações de amalgama. Todas elas evidenciam a ocorrência de uma extensiva infiltração marginal ao redor das restaurações recentes, ao passo que a percolação marginal decorrente das mudanças térmicas permite que os fluídos ocupem a interface amalgama/estrutura dentária, apresentando-se a infiltração consideravelmente reduzidas nas restaurações antigas. Talvez esse fenômeno seja atribuído à formação dos produtos de corrosão na interface estrutura dentária/amalgama. A autora relata que o verniz cavitário previamente aplicado nas paredes cavitárias é efetivo em reduzir a microinfiltração marginal inicial. Com relação às resinas acrílicas e compostas, parece que a termociclagem destroi rapidamente o selamento inicial, embora ainda existam na literatura poucos estudos abordando o comportamento das resinas compostas. A diferença no desempenho dos materiais está provavelmente relacionada à diferença no seu coeficiente de expansão térmica. 
No ano de 1978, KIDD; HARRINGTON; GRIEVE ${ }^{104}$, verificaram “in vitro” a influência da ciclagem térmica na infiltração marginal e no desenvolvimento de cáries em restaurações de classe $\mathrm{V}$ com resina composta em pré-molares humanos extraídos. Após a confecção das restaurações, os dentes foram envolvidos com algodão embebido em água destilada por uma semana e então seccionados dividindo as restaurações ao meio. Uma parte destas hemi-secções serviram de controle e foram armazenadas em algodão molhado; as demais foram subdivididas em dois grupos, o primeiro foi termociclado por 200 vezes com banhos de 1 minuto a $60^{\circ} \mathrm{C}$ e $4^{\circ} \mathrm{C}$, o segundo grupo foi também termociclado a estas temperaturas com um banho intermediário adicional a $37^{\circ} \mathrm{C}$ em cada ciclo. Ao final, todas as amostras foram colocadas em uma gelatina acidificada (ácido láctico de $\mathrm{Ph} 4,0$ ) por 10 semanas. As avaliações ao microscópio demonstraram uma maior prevalência de lesões nas paredes cavitárias das amostras do grupo controle. Baseados nos resultados, os autores concluíram que a percolação em restaurações de resina composta não deve ser significativa clinicamente.

As influências do estresse mecânico, da ciclagem térmica e da consistência da resina composta na infiltração marginal em restaurações preventivas oclusais, foram examinadas por RAADAL $^{162}$ em 1979. Para o experimento foram preparadas cavidades sem exposição de dentina e estes dentes foram divididos em 6 grupos, onde o primeiro serviu como controle, não recebendo ataque ácido prévio à restauração. Os demais grupos foram restaurados variando a consistência do compósito pela sua diluição em resina fluída. As amostras foram submetidas a estresse mecânico, com 20 ciclos de aplicação de carga , variando de zero até $147 \mathrm{~N}$ durante um período de 7 segundos utilizando uma máquina de ensaio. Os dentes foram, 
então, armazenados a $37^{\circ} \mathrm{C}$ por 3 dias e submetidos a 25 ciclos com banhos às temperaturas de $4+/-1^{\circ} \mathrm{C}$ e $60+/-2^{\circ} \mathrm{C}$ em azul de metileno a seccionados e examinados ao microscópio. Todas as amostras do grupo controle exibiram infiltração, já as restaurações realizadas com ataque ácido foram capazes de resistir à microinfiltração, mesmo submetidas a estresse mecânico e térmico.

Por acreditar na microinfiltração como principal problema associado ás restaurações, $\mathrm{GOING}^{74}$, em 1979, revisou a literatura constatando a existência de novos materiais, técnicas, métodos de análise e diagnósticos os quais oferecem eventualmente a oportunidade de eliminar a infiltração nas margens das restaurações. Observou técnicas diversas para confecção de cavidades e aplicação das resinas compostas, a maioria afirmando que o condicionamento ácido do esmalte e o emprego de um material de baixa viscosidade favorecem o selamento marginal, sugerindo consequentemente uma configuração cavitária com preservação da maior quantidade possível de esmalte adjacente. Alguns dos trabalhos revisados recomendam a confecção do bisel proximal, propiciando além de uma maior definição a exposição da subsuperfície de esmalte, mais reativa aos efeitos do condicionamento ácido. Outros, sugerindo diferentes terminações sem bisel, bisel curto, chanfrado, ângulos internos arredondados, enfim as mais variadas sugestões, as quais não poderiam ser aplicadas em todas as situações clínicas. Com relação às restaurações de amálgama, o autor ressaltou que embora vários outros procedimentos clínicos sejam importantes para o sucesso das restaurações, aquele que melhor controla a microinfiltração marginal consiste na aplicação de duas camadas de verniz copal em todas as superfícies cavitárias, incluindo o angulo cavosuperficial. $\mathrm{O}$ autor concluiu que, mesmo com o progresso significativo dos novos materiais e técnicas de aplicação das resinas compostas, o problema 
da microinfiltração continua. Na realidade, existem meios para reduzi-lo, mas não para eliminá-lo. Assim, o objetivo dos trabalhos futuros deverá ser a busca de materiais e técnicas com a finalidade de eliminar a fenda marginal conseqüente da contração de polimerização associada às resinas.

ÁVILA JÙNIOR ${ }^{6}$, em 1979 comparou o grau de infiltração marginal em restaurações realizadas com diferentes materiais restauradores plásticos. Cavidades simples, similares às de classe $\mathrm{V}$, foram preparadas no terço médio de 150 dentes humanos extraídos e distribuídas em três grupos de 50 unidades cada, os quais seriam avaliados nos períodos de 24 horas, uma semana e um mês. O amálgama de prata (Finalloy), um cimento de silicato (Porcelana), uma resina acrílica (Sevitron), e uma resina quimicamente ativada (Concise) foram os materiais envolvidos no estudo. Cada grupo foi por sua vez subdividido em 5 subgrupos de 10 unidades, restaurados com os quatro materiais plásticos, sendo que para a resina composta foram utilizados 20 dentes, 10 para cada técnica de manipulação, constituíndo as seguintes condições experimentais: Grupo A - para cada subgrupo foi utilizado um material restaurador. Em um dos subgrupós relacionados ao emprego da resina composta, foi a mesma manipulada seguindo as recomendações do fabricante e, para o segundo a resina pasta e a resina fluída foram manipuladas em conjunto. Após restaurados, os espécimes eram mantidos por uma hora imersos em saliva artificial a $37^{\circ} \mathrm{C}$ e então submetidos a 3 ciclagens térmicas em saliva artificial corada com fluoresceína sódica num período de 24 horas. Para os grupo B e C diferenciou-se apenas o tempo de armazenamento dos espécimes sendo de uma semana e um mês respectivamente, realizando-se 3 ciclagens térmicas diárias. Ao término da última termociclagem, os dentes eram seccionados e microscopicamente avaliados quanto ao grau de penetração do corante. Com base nos resultados o autor concluiu que: - o índice de infiltração 
foi variado entre os diferentes materiais testados; o amálgama e a resina composta apresentaram menores índices de infiltração no intervalo de 24 horas; a resina composta apresentou a melhor capacidade de vedamento marginal em relação aos demais materiais, nos intervalos de 1 semana e 1 mês; a modificação da técnica de manipulação da resina composta não influenciou a intensidade de infiltração marginal.

Um estudo comparativo da adaptação marginal em restaurações de classe V com resina composta, em molares humanos com e sem antagonistas, foi realizado por CRIM; MATTINGLY ${ }^{36}$, em 1981, Eles compararam dois métodos de avaliação de microinfiltração “in vitro" em restaurações de classe V em resina composta em pré-molares humanos extraídos. Metade das amostras foi imersa em fucsina básica a $0,5 \%$ à temperatura de $37^{\circ} \mathrm{C}$ por 25 horas e a outra metade foi termociclada durante 25 horas ( 1.500 ciclos) com banhos de 4 segundos a $60^{\circ} \mathrm{C}, 23$ segundos a $37^{\circ} \mathrm{C}, 4$ segundos a $5^{\circ} \mathrm{C}$ e 23 segundos a $37^{\circ} \mathrm{C}$. A infiltração marginal foi maior nas amostras submetidas à termociclagem e baseados nos resultados, os autores sugeriram a sua utilização nos estudos de microinfiltração.

Considerando que a contração de polimerização das resinas compostas consiste em uma das causas de falhas marginais por dificultar a obtenção de uma adequada adesividade, em 1982 BOWEN; RAPSON; DICKSON ${ }^{16}$ avaliaram, além dessa propriedade, a expansão higroscópica das resinas compostas. Foi com a finalidade de verificar se os materiais expandiam o suficiente para compensar a contração de polimerização inicial que sofriam quatro marcas comerciais de resina que foram testadas: Adaptic, Cervident, Concise e NuvaFil, uma resina acrílica Sevitron e três resinas experimentais com $75 \%$ de carga. A diferença característica apresentada por tais materiais consistia no monômero diluente (TEGMA, 
HEMA e Silano). Os resultados obtidos após os testes mostraram que estes materais contraem durante a polimerização, expandindo-se posteriormente quando submersos em água. No entanto, apenas os espécimes de resina acrílica e de uma resina composta experimental, onde o monômero era o HEMA, expandiram o suficiente para compensar a contração inicial. Os autores concluíram que a expansão higroscópica pode contribuir para aliviar as tensões acumuladas durante a contração de polimerização, sendo portanto possível formular resinas compostas que permitam uma expansão higroscópica suficientemente alta para compensar a contração inicial sofrida pelo material.

NAKABAYASHI; KOJIMA; MASUHARA ${ }^{143}$, em 1982, propuseram que a adesão micromecânica pode ocorrer pela infiltração do monômero de resina na superfície dentária. Quando este monômero se polimeriza, ele produz uma "camada híbrida", ou uma dentina reforçada por resina que é composta por colágeno da dentina e hidroxiapatita que está infiltrada e circundada pelo polímero.

QVIST $^{161}$, em 1983, realizou um estudo comparativo da adaptação marginal em restaurações de classe V com resina composta em molares humanos, com e sem antagonistas. Os dentes foram extraídos quatro meses após a confecção das restaurações e o vedamento marginal foi verificado por um método de colaração de microorganismos. Os resultados demonstraram uma maior penetração bacteriana nos molares que apresentavam antagonistas, levando à conclusão de que a mastigação exerce uma grande influência na adaptação marginal de restaurações com resina e o seu efeito deve ser considerado no planejamento dos testes de microinfiltração. 
Diante da problemática de adaptação marginal das restaurações plásticas diretas, TAYLOR; LINCH ${ }^{189}$, em 1983, realizaram uma revisão dos aspectos mais relevantes no que se refere aos seus efeitos sobre a adaptação marginal. Foram discutidos fatores relativos às cavidades, como a conformação cavitária, tamanho das cavidades e localização das margens das mesmas. Aspectos dos materiais restauradores também forma comentados, segundo suas técnicas de inserção, sua adaptação interna e externa, sua própria escolha e, seu método de ativação, seu acabamento e polimento, assim como a escolha e o efeito de bases. Além destes pontos, abordaram-se as formas de avaliação das margens cavitárias, em estudos "in vivo". O autor relata que são vastas as metodologias existemtes para se avaliar a adaptação marginal de restaurações. No entanto, ainda não existe uma padronização adequada para esta avaliação.

DAVIDSON; DE GEE ${ }^{43}$, em 1984, mediram as tensões de endurecimento de duas resinas compostas quimicamente ativadas (Silar e Concise) e compararam esses resultados com os valores calculados teoricamente. Os dados obtidos mostraram que os valores obtidos experimentalmente foram significantemente menores que aqueles obtidos teoricamente. Dos resultados obtidos, os autores concluíram que durante o polimerização (endurecimento) das resinas compostas o escoamento causa tensões, que são compensadas pela contração, a qual é máxima no estágio inicial de endurecimento, devido ao material ainda ser fraco e capaz de relaxar. Os autores presumiram que neste estágio acontece somente a formação de cadeias e os entrelaçamentos ainda não estão completamente estabelecidos; com isso, as moléculas podem deslocar-se para novas posições e orientações. Após algum tempo, o material ganha resistência e menor capacidade de relaxar, porque a contração diminui. Aos 45 minutos aproximadamente, um total de $95 \%$ da contração de polimerização se expirou. 
EHRNFORD; DERAND ${ }^{55}$, em 1984, realizaram medidas das fendas marginais cervicais formadas em restaurações com resina composta de cavidades de classe II em prémolares humanos extraídos. Neste estudo foram utilizados 3 tipos de resina composta: uma de polimerização química com partículas de tamanho "regular", uma de micro-partícula polimerizada por luz ultra-violeta e uma experimental. Todas as restaurações foram precedidas de ataque ácido e aplicação de resina fluída. Os exames em microscopia eletrônica de varredura demonstraram a presença de fendas marginais cervicais em torno de $35 \mu \mathrm{m}$ para as duas primeiras resinas e de $10 \mu \mathrm{m}$ para o compósito experimental.

Em 1985, o COUNCIL ON DENTAL MATERIALS, INSTRUMENTS AND EQUIPMENT $^{32}$ publicou um relato sobre as resinas compostas fotoativadas e as unidades de fotoativação. As resinas compostas foram descritas comparando-as com as resinas quimicamente ativadas. Relatou-se que as primeiras diferem apenas das segundas no que se refere aos agentes ativadores e iniciadores e, desde que polimerizadas adequadamente, as resinas fotoativadas possuem propriedades físicas e mecânicas semelhantes às resinas quimicamente ativadas. Foi ressaltado que uma subpolimerização está normalmente relacionada com propriedades inferiores; e que o grau interno de polimerização diminui conforme aumenta a distância da superfície da restauração e a fonte de luz, desta forma uma superfície mais rígida não significa uma adequada polimerização ao longo de todo corpo da restauração. Para tanto, foi sugerido que a resina fosse inserida em incrementos de 2 a $3 \mathrm{~mm}$, fotoativadas individualmente. Ainda, as resinas compostas fotoativadas foram relatadas como portadoras de algumas vantagens clínicas como maior tempo de trabalho e maior facilidade de manipulação. Com relação às unidades fotoativadoras, foi relatado que elas emitem um comprimento de onda de 400 a $550 \mathrm{~nm}$, havendo diferenças na distribuição do espectro de luz, 
na intensidade desta luz e na radiação emitida por estes aparelhos. Ainda não se tinha conhecimento sobre o valor da intensidade de luz que seria mais efetivo no processo de fotoativação. Também eram escassos as informações sobre o quanto a intensidade de luz e a distribuição do espectro de luz são afetados pela voltagem da rede, as idades dos filtros e do bulbo, as condições do tubo. Recomendou-se cautela ao manipular estas unidades, através de uso de filtros protetores, pois até então não se tinha conhecimento de como a luz emitida pelos aparelhos poderia afetar os tecidos bucais e a córnea humana.

CRIM; SWARTZ; PHILLIPS ${ }^{37}$, em 1985, compararam o desempenho de diferentes técnicas de termociclagem e dois tipos de demarcadores de infiltração marginal em restaurações de classe V com resina composta em pré-molares humanos extraídos. Dois testes de termociclagem foram avaliados, o primeiro compreendeu 1.500 ciclos de 4 banhos com tempos de imersão de 4 segundos a $60+/-2^{\circ} \mathrm{C}, 23$ segundos a $37+/-2^{\circ} \mathrm{C}, 4$ segundos a $12+/-$ $2^{\circ} \mathrm{C}$ e 23 segundos a $60+/-2^{\circ} \mathrm{C}$; o segundo teste consistiu de 1500 ciclos de 2 banhos mantidos a $60+/-2^{\circ} \mathrm{C}$ e $12+/-2^{\circ} \mathrm{C}$ por 30 segundos. Após restaurados, os dentes foram divididos em 4 grupos onde o primeiro grupo foi submetido ao primeiro teste com banhos em fucsina básica a 0,5\%; o segundo grupo também submeteu-se a este mesmo teste com ciclagem em água e posterior imersão em fucsina básica por 24 horas, no terceiro grupo foi aplicado o segundo teste com banhos em água e imersão em fucsina básica por 24 horas, após a ciclagem; no quarto grupo também foi usado o segundo teste com banhos em água e posterior avaliação por meio de autorradiografias utilizando solução de cálcio radioativo; finalmente um quinto grupo foi classificado como controle, onde espécimes não termociclados foram imersos em fucsina básica por 24 horas. A investigação não revelou diferenças significativas entre os 2 testes e os 4 grupos termociclados, nos quais a infiltração foi maior que no grupo controle. $\mathrm{O}$ uso da 
fucsina ou do isótopo foi similar para verificação do grau de infiltração e não houve diferença na profundidade de penetração entre os espécimes ciclados em corante e aqueles imersos na solução demarcadora após a termociclagem.

GROSS; RETIEF; BRADLEY ${ }^{78}$, em 1985, avaliaram “in vitro” a microinfiltração marginal em cavidades de classe II MOD, em molares humanos extraídos, restaurados com uma resina compostas ativada quimicamente ( P-10) ou uma resina fotopolimerizável (P-30), usadas em associação com uma resina fluída ( Enamel Bond ) ou um sistema adesivo dentinário ( Scotchbond ). As paredes gengivais das caixas mesiais foram terminadas em esmalte e as distais em cemento/dentina. Após as restaurações, as amostras foram termocicladas em uma solução de cálcio radioativo e a infiltração foi avaliada por meio de autorradiografias. Houve penetração da substância tanto nas caixas mesiais quanto nas distais, entretanto esta foi menor onde havia a presença de esmalte. Baseados nestes resultados "in vitro”, os autores destacaram que a microinfiltração em restaurações de classe II com resina deve ocorrer em situações clínicas, principalmente ao nível das paredes gengivais.

MUNKSGAARD; ITOH; JORGENSEN ${ }^{138}$, investigaram em 1985 o efeito da ciclagem térmica e da aplicação de carga axial na adesão estabelecida pelo uso combinado de dois agentes de união ( Gluma e Clearfil Bond) em restaurações de classe III e V com uma resina composta de micropartículas (Silux) em dentes humanos extraídos. Para realização do teste térmico, os dentes restaurados foram divididos em 4 grupos de 10, de acordo com o número de ciclos térmicos empregados e o tempo de armazenamento antes dos testes. Cada um destes ciclos consistiu de banhos de 14 segundos a $15^{\circ} \mathrm{C}$ e $50^{\circ} \mathrm{C}$. Imediatamente após a termociclagem, os espécimes foram imersos em solução aquosa de eritrosina a 9\% por 10 
segundos para o posterior exame microscópico. No teste mecânico, as amostras foram submetidas a compressão por 5 segundos e aliviadas por igual período de tempo durante 11 vezes, com cargas crescentes de 2, 4, 8, 12 e $16 \mathrm{~kg}$, usando uma máquina universal de ensaio. Ao final, todas as amostras foram examinadas ao microscópio e os autores concluíram que a utilização do Gluma em combinação com o Clearfil Bond como agente de união entre a dentina e a resina foi capaz de resistir aos estresses térmico e mecânico, prevenindo a ocorrência de fendas marginais.

FERRACANE $^{62}$, em 1985, realizou um estudo com resinas compostas quimicamente ativadas ( Delton Pit and Fissure Sealant, Profile Bonding Agent, Concise Enamel ) com o objetivo de determinar a correlação entre dureza Knoop e o grau de conversão das duplas ligações de carbono nestas resinas. Verificou-se que haveria uma correlação entre o aumento da dureza durante a polimerização das resinas com o aumento do grau de conversão das mesmas. No entanto, o valor absoluto da dureza não poderia ser utilizado para predizer um valor absoluto para o grau de conversão de todas as resinas, uma vez que as propriedades mecânicas das resinas seriam muito dependentes das ligações cruzadas formadas e da qualidade da rede destas ligações ocorridas durante a polimerização, o que não seria sinônimo da conversão destes materiais. Portanto, dever-se-ia restringuir os testes de dureza quando se desejasse avaliar o grau de conversão de uma resina e ter cautela ao interpretar os resultados.

O trabalho de pesquisa desenvolvido “in vitro" por GOTTLIEB; RETIEF; BRADLEY $^{77}$, em 1985, apresentou por propósito analisar a infiltração marginal em restaurações de amálgama realizadas com ligas convencionais e com alto conteúdo de cobre. Cavidades de classe V foram confeccionadas em 160 dentes pré-molares humanos extraídos, 
os quais foram distribuídos em quatro experimentais: 1- restaurações com liga convencional (Velvalloy); 2- restaurações com liga de alto conteúdo de cobre (Tytin); 3-4 mesmas condições dos grupos 1 e 2, com aplicação do verniz cavitário (Copalite) antecedendo a inserção do amálgama. Após 24 horas, realizou-se o polimento das restaurações, sendo as amostras armazenadas em saliva artificial durante 2 semanas, 3, 6 e 12 meses. Ao término de cada período determinado, os espécimes foram submetidos a 400 ciclos térmicos por 3 horas, nas temperaturas de $5^{\circ} \mathrm{C}$ e $55^{\circ} \mathrm{C}$. A infiltração marginal foi determinada através do uso de solução corante radioativa e de auto-radiografias. Pelos resultados pode-se verficar que as restaurações com o amálgama convencional, sem o uso do verniz cavitário, apresentaram redução da microinfiltração marginal gengival e oclusal, após o armazenamento em saliva sintética durante 6 e 12 semanas, respectivamente. Com a aplicação do verniz cavitário antecedendo a inserção do amálgama convencional, houve redução da microinfiltração marginal oclusal somente no intervalo de 2 semanas. Por outro lado, as restaurações com amálgama de alto conteúdo de cobre exibiram marcada infiltração durante todo o estudo e, aos 12 meses, houve maior ocorrência de espécimes com índice máximo de infiltração marginal em comparação às restaurações realizadas com a liga convencional. Foi observado, ainda, que a aplicação do verniz cavitário associado ao amálgama contendo alto teor de cobre não apresentou efeito significativo quanto ao selamento marginal das restaurações.

A necessidade de desenvolver sistemas adesivos capazes de promover reação química entre as resinas compostas e as estruturas dentárias consiste atualmente na principal preocupação dos pesquisadores. Em 1985 Mc LEAN; PROSSER; WILSON ${ }^{125}$, questionaram se o uso dos cimentos ionoméricos em associação às resinas ofereceriam possivelmente uma solução. A dentina ou esmalte cervical seriam selados com o cimento de ionômero de vidro, 
sendo a resina composta utilizada para restaurar a estrutura de esmalte. Assim, o estudo por eles desenvolvido, através do qual procuraram associar as propriedades favoráveis destes dois materiais, indicou o cimento de ionômero de vidro como base para as restaurações de resinas compostas. A possibilidade de ocorrer adesão entre a resina e o ionômero foi examinada com o emprego da resina Espe Visio-Dispers e o cimento ionomérico Espe Ketac cement, sendo a força adesiva investigada por meio de testes de cisalhamento. Através da microscopia eletrônica, observou-se que a superfície do ionômero poderia ser condicionada com ácido fosfórico, proporcionando uma superfície mais áspera, o que favorecia a união com a resina composta. O condicionamento provocaria o aparecimento de fendas e espaços, pela extração do cálcio, alumínio e sílica do cimento. A análise das superfícies de ambos os materiais mostrou projeções e espaços vazios, comprometendo a interação mecânica entre eles. Os testes de cisalhamento apresentavam valores de 10,25 mais ou menos 1,61 $\mathrm{MPa}$, quando o ionômero recebia o condicionamento ácido, e de 6,5 mais ou menos 3,0 Mpa, quando o mesmo não era realizado. Como esta diferença mostrou-se estatisticamente significante, consideraram que o condicionamento ácido do cimento favorece a força de união na interface ionômero de vidro/resina composta. Consideraram, também, que a força de união entre os dois materiais parece ser maior que a resistência inerente do próprio cimento ionomérico, tendo em vista a ocorrência de fraturas de natureza coesiva no corpo deste material. Nesse mesmo trabalho os autores descreveram a técnica recomendada para restaurar cavidades de classe III e V, utilizando estes dois materiais. Os autores esclareceram ser este um método de restauração de fundamental importância, por proporcionar a fixação da resina ao esmalte e dentina, utilizando o cimento ionomérico como agente intermediário, melhorando assim o aspecto estético da restauração e aumentando o poder de adesão do material restaurador à cavidade. Foi discutido ainda, que a força de adesão dos cimentos à estrutura dental poderia 
ser aumentada através do uso de condicionadores dentinários tais como o ácido poliacrílico, o ácido titânico ou o dodecim. Tais substâncias não danificariam a superfície dentinária e seriam mais efetivas do que os agentes desmineralizantes como o ácido cítrico e o EDTA, que alteram a composição mineral da dentina. Os autores consideraram que a longevidade das restaurações posteriores por meio desta técnica ainda não foi estabelecida.

Através deste estudo, YEARN ${ }^{207}$, em 1985, levantou os principais fatores que determinariam a qualidade de polimerização e, portanto, determinariam o desempenho das resinas compostas fotoativadas. Salientou a importância de se medir a profundidade de polimerização, pois tratar-se-ia do ponto de maior divergência entre os fabricantes. Assim, descreveu três métodos de medição da profundidade de polimerização. $\mathrm{O}$ autor relatou a variabilidade de composição das resinas e seus mecanismos de reação, salientando que as principais variáveis na composição das resinas compostas que determinariam a polimerização de cada um de seus incrementos seriam incrementos seriam aqueles que influenciariam a capacidade da luz em alcançá-los, ou seja, seriam os fatores que facilitariam ou dificultariam a transmissão de luz. Também de grande importância seria o espectro de luz. Comprimentos de onda abaixo de $400 \mathrm{~nm}$ não confeririam uma fotoativação adequada aos compósitos. Da mesma forma, valores acima de $500 \mathrm{~nm}$ pouco contribuíram com a fotoativação e ainda gerariam calor suficientemente capaz de trazer efeitos deletérios à polpa e aos tecidos moles. Ressaltou-se que a intensidade de luz utilizada é o fator mais importante na polimerização de resinas compostas, e é função do tipo de unidade de luz empregada. Assim sendo, recomendou-se o uso de unidades fotoativadoras com reguladores de voltagem, já que a mínima alteração no fornecimento de energia poderia causar uma desproporção no comprimento de onda crítico, fator fundamental para uma adequada polimerização. Além 
disso, destacou-se o papel do profissional no que se refere ao controle do tempo de irradiação e a distância da fonte de luz à superfície do material. De acordo com o autor, do mesmo modo que ocorreria com o aumento da intensidade de luz, aumentar-se-ia a profundidade de polimerização, aumentando o tempo de exposição. No entanto, haveria que se considerar que, uma vez atingida a máxima polimerização até camadas mais profundas através do aumento do tempo de exposição já que a luz seria incapaz de penetrar até estas camadas. A fonte de luz deveria ficar o mais próximo possível do material, devendo-se ter o cuidado para não contaminar a ponta da unidade fotoativadora .

DAVIDSON $^{39}$, em 1987, estudou a relação da configuração cavitária com a contração de polimerização das resinas compostas, relatando que para obter-se uma adequada adaptação do material, é necessária uma interação mecânica ou físicomecânica segura entre o compósito e as paredes cavitárias, devendo a mesma ser capaz de resistir ao estresse causado pela contração de polimerização. O autor afirma também que em determinadas circunstâncias, como em restaurações de classe I, devido à adesão do material em todas as paredes, o estresse gerado pela contração poderá exceder a força adesiva da resina composta à estrutura dentária, rompendo-se. O autor concluiu então que existe uma interdependência entre as tensões geradas durante a contração e a configuração da cavidade.

STEWART; BALDA; NORMAN ${ }^{185}$, em 1986, avaliaram o efeito do esforço mecânico ( compressão ) com e sem termociclagem na integridade marginal de restaurações classe V de resina composta com margens em esmalte, em pré-molares humanos extraído. Os dentes foram divididos aleatoriamente em 6 grupos, onde o primeiro ( controle ) não foi submetido a qualquer tipo de estresse; o segundo grupo foi termociclado por 500 vezes entre 
$10^{\circ} \mathrm{C}$ e $50^{\circ} \mathrm{C}$; o terceiro foi submetido a 5.000 compressões de 5 libras; o quarto a 5.000 compressões de 15 libras; o quinto a 5.000 de 31 libras e o último grupo foi termociclado por 500 vezes e comprimido com 31 libras e o último grupo foi termociclado por 500 vezes e comprimido com 31 libras por 5.000 vezes. Após estes testes, a microinfiltração foi verificada por meio de autorradiografias. Os resultados indicaram que as restaurações foram capazes de resistir aos esforços mecânicos e ao estresse térmico sem um significativo detrimento da união entre o esmalte e o material restaurador, levando os autores a concluir que a aplicação de moderadas cargas, com ou sem ciclagem térmica, sobre restaurações de resina composta, não produziram estresse suficientemente para romper a união ao esmalte.

A infiltração marginal e a consequente sensibilidade pós-operatória continuam sendo fatores preocupantes relacionados com as restaurações estéticas de resina composta. Vários estudos têm sido desenvolvidos, com resultados favoráveis quanto à redução ou eliminação da microinfiltração nas restaurações de resina com margens em esmalte. Foi com este mesmo intuito que WELSH; HEMBREE ${ }^{199}$ em 1986, testaram a infiltração resultante do uso de quatro marcas comercias de materiais restauradores inseridos em cavidades simulando abrasão ou erosão cervical, cujas margens gengivais se estendiam à região de cemento. A resina Concise foi utilizada como controle negativo, uma vez que esse material adere quimicamente à superfície de dentina ou cemento, sendo testadas, também, as resinas DentMat e Clearfil. Um total de setenta e dois dentes incluindo anteriores e pré-molares foram restaurados e termociclados. Cada grupo de espécimes foi testado nos períodos de uma semana, três e seis meses. A adaptação marginal para cada espécime foi avaliada pela presença de isótopos na interface estrutura dentária/material restaurador. Os resultados acusaram uma infiltração cervical significante para as resinas Dent-Mart, Concise e Clearfil 
em todos os intervalos de tempo. Os melhores resultados foram correspondentes ao cimento de ionômero de vidro Fuji, com mínima infiltração de isótopos.

LUTZ; KREJCI; OLDENBURG ${ }^{119}$, em 1986, partindo da premissa de que a contração de polimerização de resina composta dar-se-ia em direção à fonte de luz e estaria diretamente relacionada ao volume da massa deste material, propuseram uma nova técnica restauradora denominada de técnica de três incrementos. Segundo os autores, a hipótese era a de que haveria uma melhor adaptação marginal para cada instrumento numa teórica multiincremental. Cavidades MOD foram confeccionadas e restauradas em molares humanos com uma resina fotoativada de acordo com a técnica proposta. Esta técnica consistia da inserção do primeiro incremento seria no terço cervical da caixa proximal, sendo que sua fotoativação seria realizada através de uma cunha refletiva; o segundo incremento seria em dois terços da região vestibular da caixa proximal, por onde seria fotoativado; o terceiro teria um volume menor do que o segundo, sendo inserido de encontro à parede lingual; o quarto e último incremento seria o da caixa oclusal, sofrendo fotoativação também por oclusal. Os dentes foram divididos em 4 grupos, dos quais apenas três sofreram condicionamento ácido do esmalte e apenas dois receberam uma base de ionômero de vidro. Os espécimes forma submetidos à ciclagem mecânica e térmica. As superfícies proximais foram analisadas em microscópio e o selamento marginal foi analisado através da medição da infiltração de corante. De acordo com os resultados, os autores afirmaram que a técnica de inserção e fotoativação dos incrementos atingiu um bom desempenho, melhorando a qualidade estabilidade marginal das restaurações. Entretanto ressaltam que não bastaria melhorar a resistência adesiva ao esmalte ou à dentina para solucionar o problema do estresse gerado pela contração de polimerização, o qual excederia as forças adesivas. 
LUTZ $^{119}$, ainda em 1986, juntamente com KREJCI; OLDENBURG, com o propósito de favorecer a adaptação marginal das restaurações de resina composta, desenvolveram uma técnica restauradora para dentes posteriores, usando uma técnica incremental para a inserção da resina composta. A primeira e menor camada era colocada junto à parede gengival (polimerizada via cunha reflectiva por 60 segundos), a segunda (e maior) era acomodada na parte vestibular e polimerizada via vestibular e o espaço restante era preenchido e polimerizado por lingual. Esse procedimento, segundo os autores, evitaria a formação de um vetor de contração para oclusal, quando o material restaurador fosse polimerizado por essa mesma face. As restaurações foram polidas imediatamente após a sua conclusão. Os autores submeteram então as restaurações à carga de $72,5 \mathrm{~N}$ em uma freqüência de $1,6 \mathrm{~Hz}$ por 500.000 ciclos, seguidos de ciclagem térmica $\left(2.500\right.$ ciclos a $\left.5-55^{\circ} \mathrm{C}\right)$ e, após, os espécimes foram imersos em solução corante (fucsina básica a 0,05\% durante 20 horas). Os diversos grupos variaram quanto ao tipo de tratamento feito no esmalte (quanto à execução ou não do ataque ácido no esmalte) e no preenchimento da cavidade (quanto ao preenchimento ou não com ionômero e ao tratamento com ácido ou não). A micromorfologia das interfaces e o grau de infiltração do corante na interface resina composta - superfície gengival foram avaliados. Os resultados revelaram que as melhores margens aconteceram no grupo que utilizou o conjunto ataque ácido do esmalte mais o preenchimento com ionômero de vidro, sem posterior ataque ácido. Os autores salientaram ainda que isso ocorreu devido à não adesão da resina composta ao ionômero de vidro, que não se deslocou da superfície dentária durante a contração de polimerização da resina composta. Concluíram ainda que, pela inexistência de uma resina composta que não possua contração de polimerização, cabe ao clínico a responsabilidade de 
tentar compensar essas características desfavoráveis, lançando mão de procedimentos técnicos que propiciem melhor adaptação do material restaurador às paredes cavitárias.

Mais tarde, em 1987, FAYYAD; SHORTALL ${ }^{58}$, através de estudos “in vitro”, avaliaram a qualidade do selamento marginal das resinas compostas, inseridas em cavidades de classe II extensas. Duas resinas compostas de uso posterior ( P-30 e Clearfil Ray ), associadas a três sistemas adesivos dentinários ( Scothbond, Clearfil New Bond e o Gluma Bond ) e a um cimento de ionômero de vidro (Ketac-Bond), foram testadas neste trabalho. Cavidades MOD; foram preparadas em quarenta terceiros molares humanos hígidos extraídos. Cada preparo apresentou uma das caixas proximais com o término cervical a 1 mais ou menos 0,25 mm aquém da junção cemento-esmalte e, a outra, 1 mais ou menos 0,25 mm além dessa mesma junção. Quinze minutos após o término das restaurações, realizaram o acabamento e o polimento, com posterior armazenamento em água destilada à $37^{\circ} \mathrm{C}$, permanecendo por 1 minuto em cada temperatura. Dando continuidade, os espécimes foram seccionados longitudinalmente no sentido mésiodistal e analisados em um estereomicroscópio, ao qual foi acoplado um dispositivo de análise de imagem, sendo o grau de penetração do corante na interface dente/restauração quantificado. Pelos resultados, os autores observaram que nenhum dos materiais impediu a penetração do corante, porém, o cimento ionomérico reduziu significantemente a microinfiltração nas margens das restaurações.

Foi também com propósito de avaliar a microinfiltração através da junção cementoesmalte em restaurações estéticas posteriores de resinas compostas que, em 1987, KANCA III $^{100}$ desenvolveu um trabalho de pesquisa, utilizando o sistema adesivo Scothbond/resina P30 em associação ou não ao cimento ionomérico Ketac-Bond. Vinte cavidades de classe II 
MOD foram confeccionadas de modo que a parede cervical se estendesse além da junção amelocementária. Para o primeiro grupo de dez elementos, toda a dentina exposta durante o preparo cavitário foi coberta com o Ketac-Bond e, para o grupo seguinte, uma pequena quantidade de dentina próxima ao ângulo cavosuperficial gengival foi mantida sem forramento. Em seguida, todos os espécimes eram restaurados com o sistema Scothbond /resina P-30. Os ápices radiculares foram selados com o próprio compósito restaurador e todo o dente isolado com esmalte de unha, até $2 \mathrm{~mm}$ aquém da margem da restauração. Os dentes restaurados passaram por um processo de ciclagem térmica por 24 horas, sendo em seguida imersos em solução de fucsina básica a 0,5\%, aguardando-se 72 horas. Decorrida este período, os espécimes foram seccionados longitudinalmente e submetidos à análise do índice de penetração do corante ao longo da interface mencionada, por meio da atribuição de escores, com o auxílio de um microscópio óptico com aumento de trinta vezes. A análise dos resultados demonstrou um índice de infiltração significantemente menor quando a base de cimento de ionômero de vidro estendia-se ao ângulo cavosuperficial gengival, em comparação aqueles espécimes nos quais uma pequena quantidade de dentina próxima à margem mantevese desprovida de forramento.

CRIM; GARCIA-GODOY ${ }^{35}$, no ano de 1987, compararam os efeitos do tempo de armazenagem das restaurações e do número de ciclos térmicos na microinfiltração de restaurações de resina composta. Cavidades de classe $\mathrm{V}$ em esmalte foram preparadas nas faces vestibulares e linguais de pré-molares humanos extraídos, após as restaurações, os dentes foram divididos em 4 grupos de acordo com os procedimento empregados. O primeiro grupo foi imediatamente submetido a 100 ciclos térmicos e o segundo a 1.500; o terceiro e quarto grupos foram armazenados em água à temperatura ambiente por 24 horas e então 
submetidos a 100 a 1.500 ciclos térmicos respectivamente. Cada ciclo térmico constou de 23 segundos a $37^{\circ} \mathrm{C}, 4$ segundos a $54^{\circ} \mathrm{C}, 23$ segundos a $37^{\circ} \mathrm{C}$ e 4 segundos a $12^{\circ} \mathrm{C}$. Logo após a termociclagem, as amostras foram colocadas em uma solução de fucsina básica por 24 horas e seccionadas para avaliação. Os espécimes ciclados imediatamente após a realização das restaurações exibiram penetração de corante discretamente maior que os demais, os autores atribuíram este fato à provável expansão higroscópica ocorrida nas restaurações que ficaram na água. O número de ciclos térmicos não alterou a microinfiltração.

FEILZER, DE GEE; DAVIDSON ${ }^{59}$, em 1987, estudaram as tensões geradas durante o endurecimento das resinas compostas em função da forma da cavidade. Os autores descreveram-na como fator de configuração cavitária (fator-C), que é a relação entre as superfícies aderidas/não aderidas. Para o experimento foram utilizadas duas resinas ativadas quimicamente, as quais eram posicionadas entre dois discos paralelos de metal, os quais por sua vez estavam presos a um tensímetro. Os diversos valores de fator-C foram obtidos através de cálculos e reproduzidos no experimento pela variação na distância entre esses dois discos de metal. Os resultados mostraram que: quando o fator-C foi menor ou igual a 1 , o relaxamento das tensões pelo escoamento foi suficiente para manter a coerência do material; quando o fator-C ocupou uma posição intermediária entre 1 e $2(1<\mathrm{C}<2)$, foram observadas falhas coesivas em algumas amostras e, quando o fator-C foi maior que 2, todas as amostras falharam coesivamente. Os autores concluíram então que, na maior parte das cavidades presentes clinicamente, o relaxamento das tensões pelo escoamento das moléculas não é suficiente para preservar a adesão à dentina pelos adesivos dentinários disponíveis. 
FIELDS et al. ${ }^{67}$, em 1987, estudaram as variáveis que afetam a mensuração das forças oclusais, durante a deglutição, mastigação e o máximo esforço mastigatório. Os valores encontrados demonstraram que a média da força mastigatória em adultos jovens (25 a 29 anos) foi de 17,6 $\mathrm{kg}$ com abertura bucal de $20 \mathrm{~mm}$. Os autores ainda relataram que outros estudos têm demonstrado resultados inconscientes e conflitantes, principalmente pela falta de controle de variáveis como idade, sexo, metodologia, estado da dentição, extensão da abertura, postura da cabeça, registros unilateral ou bilateral.

Em 1987 WARREN JUNIOR; CLARK ${ }^{198}$, revisando a literatura, salientaram as vantagens e recomendaram o uso da técnica incremental sobre a técnica de incremento único, devido à redução na tensão gerada (flexão de cúspides) e também diminuição na fenda marginal provocada pela contração de polimerização.

Foi com o objetivo de padronizar os métodos de avaliação da microinfiltração marginal nas restaurações adesivas que, em 1987, RETIEF $^{164}$ revisou criteriosamente a literatura sobre o assunto e questionou se as técnicas adesivas são realmente efetivas na prevenção deste incoveniente. O fenômeno de adesão foi por ele definido como o estado no qual duas superfícies que se mantêm unidas pelas forças interfaciais, químicas, mecânicas ou ambas. Definiu o adesivo como a substância capaz de manter os materiais juntos pela superfície ligada. Sendo assim, a adesão pode ser resultante de uma união mecânica ou de uma união adesiva, onde as interações físico-químicas são estabelecidas entre um adesivo e um substrato. Enfim, analisou vários trabalhos com os mais variados métodos experimentais de avaliação da microinfiltração, em restaurações de resinas compostas e cimento de ionômero de vidro, e concluiu que o condicionamento ácido do esmalte elimina efetivamente 
a microinfiltração nas restaurações de resinas compostas, particularmente quando há boa espessura de esmalte nas paredes gengivais. $\mathrm{O}$ autor sugere que, para estes tipos de testes, as cavidades sejam preparadas em dentina, apresentando forma não retentiva, e que os materiais sejam empregados exatamente como instruído pelos fabricantes. Indica a técnica de aplicação da resina em camadas oblíquas, o que reduz em aproximadamente $25 \%$ a formação de fendas marginais. As restaurações devem receber acabamento e polimento no mínimo 15 minutos após a polimerização do material. Os dentes devem ser armazenados em água destilada por 24 horas e então submetidos à termociclagem, isto porque a absorção de água pelo material reduz significantemente o espaço entre o dente e o material restaurador. A ciclagem térmica deve ser realizada preferencialmente em solução corante de escolha, durante 500 ciclos completos, nas temperaturas de $50^{\circ} \mathrm{C}$ e $8^{\circ} \mathrm{C}$, com um tempo de imersão de até 15 segundos, pois, no meio intrabucal as temperaturas não se mantêm por intervalos mais longos. Afirmou que a microinfiltração pode ocorrer mesmo com o emprego de cimentos ionoméricos e que, embora alguns agentes de união possuam o potencial de prevenir a microinfiltração, outros estudos devem ser ainda desenvolvidos no sentido de atingir tal efetividade.

DARBYSHIRE; MESSER; DOUGLAS ${ }^{38}$, em 1988, examinaram o efeito da aplicação de carga axial e da utilização de um sistema adesivo e um cimento de iônomero de vidro na microinfiltração de restaurações de classe II com resina composta realizadas em 80 prémolares humanos extraídos. Após os preparos cavitários, todos os dentes tiveram o esmalte condicionado com ácido e foram divididos em 8 grupos. Os grupos 1 e 2 foram restaurados apenas com resina composta; o 3 e o 4 foram restaurados com um sistema adesivo e resina composta; os grupos 5 e 6 com cimento de iônomero de vidro e resina composta; e os grupos 7 e 8 com cimento de iônomero de vidro, sistema adesivo e resina composta. Um grupo de 
amostras de cada técnica de restauração foi submetido a cargas axiais com 5 aplicações por segundo de forças variando de 4,5 N a 111,3 N totalizando 4000 aplicações. Em seguida, todos estes e os demais grupos de dentes foram termociclados por 500 vezes com banhos de 30 segundos a $5^{\circ} \mathrm{C}$ e $55^{\circ} \mathrm{C}$ e imersos em nitrato de prata a $50 \%$. Todas as restaurações exibiram microinfiltração, a qual não foi aumentada pela carga oclusal. Ambos, o sistema adesivo e o cimento de iônomero de vidro, reduziram a microinfiltração, com melhor desempenho deste último. A adição do sistema adesivo não influenciou de forma significativa na redução da infiltração proporcionada pelo iônomero isoladamente.

Ainda em 1988, BULLARD; LEINFELDER; RUSSEL ${ }^{19}$, realizaram um trabalho experimental, avaliando o efeito do coeficiente de expansão térmica sobre a microinfiltração. Seis materiais, com diferentes coeficientes de expansão térmica, foram testados: uma resina acrílica (Sevitron), uma resina composta de micropartículas (Silux), um cimento de óxido de zinco e eugenol (Fynal), uma resina composta para uso posterior ( Occlusin ), um amálgama ( Cluster ) e um cimento de ionômero de vidro ( Ketac-Fil ). Cavidades de classe V, com margens em esmalte, não biseladas, foram confeccionadas em sessenta dentes permanentes extraídos. Após restaurados, os dentes eram selados com duas camadas de esmalte de unha, com exceção do preparo, e 1,5 a $2 \mathrm{~mm}$ ao seu redor, e termociclados num total de 125 ciclos em solução de fucsina básica a $0,5 \%$, nas temperaturas de $5^{\circ} \mathrm{C}$ e $55^{\circ} \mathrm{C}$, com permanência de 30 segundos em cada uma. Após seccionadas, as amostras foram analisadas em microscópio de dissecção com aumento de três vezes e a penetração do corante avaliada através da atribuição de escores. Pelos resultados deste estudo, os autores concluíram haver uma forte correlação entre microinfiltração e coeficiente de expansão térmica. Relataram, também, que o emprego de materiais restauradores com baixo coeficiente de expansão térmica, como o 
cimento de ionômero de vidro, pode controlar a microinfiltração, favorecendo a adaptação da restauração.

HANSEN; ASMUSSEN ${ }^{85}$, em 1988, estudaram o efeito do intervalo de tempo entre o término de restaurações feitas com resina composta em dentes humanos extraídos e o seu polimento. Foram utilizados dois sistemas adesivos e um material restaurador. Apesar de encontrarem valores diferentes de abertura na interface dente-restauração para os dois sistemas adesivos utilizados, concluíram também quanto à necessidade de se aguardar o fechamento desta interface pela expansão higroscópica da resina antes de dar acabamento e polimento; esse fechamento levaria mais de 60 minutos para ocorrer.

MUNKSGAARD; IRIE ${ }^{136}$ em 1988, determinaram o efeito do estresse mecânico em restaurações de classe $\mathrm{V}$ realizadas com um sistema adesivo e 3 diferentes marcas de resina composta, pela avaliação da dimensão das fendas marginais. Um ciclo de 12 aplicações de cargas crescentes seguindo a ordem de 2,4,8,12 e $16 \mathrm{~kg}$ foi realizado em cada grupo de restaurações, cobertas com corante, com e sem forramento de hidróxido de cálcio. Os resultados demonstraram penetração do corante em algumas poucas restaurações com forramento e em um número mais reduzido ainda de restaurações sem forramento, quando da utilização de uma resina com alta porcentagem de carga. Os autores creditaram estes fatos à redução da área efetiva para adesão nas restaurações com forramento e ao módulo de elasticidade das resinas usadas nos demais grupos, mas, apesar destas poucas falhas, deduziram que a interface adesiva foi capaz de resistir às cargas aplicadas. 
VIEIRA $^{197}$, em 1988, avaliou a capacidade de vedamento marginal, estudando o grau de microinfiltração de corantes em cavidades M.O.D. restauradas com cinco sistemas adesivos. Foram utilizados 40 pré-molares, nos quais foram realizados cavidades de classe II M.O.D. com o término gengival de uma das caixas proximais em esmalte e, da outra, em cemento. Os dentes foram então termociclados $\left(105\right.$ ciclos entre $5^{\circ}$ e $\left.55^{\circ} \mathrm{C}\right)$ e, após, imersos em solução corante (rodamina-B a $0,1 \%$ ). Os resultados mostraram que todos os sistemas adesivos estudados foram incapazes de impedir totalmente a infiltração marginal, principalmente nas margens terminadas em cemento.

KOENIGSBERG; FUKS; GRAJOWER ${ }^{105}$, no ano de 1989, realizaram um estudo da microinfiltração nas margens cervicais e oclusais de restaurações de cavidades de classe II em esmalte com resina composta, confeccionadas por duas técnicas incrementais ( gengivooclusal e vestíbulo-lingual ) e pela técnica de incremento único. Após as restaurações, os dentes foram termociclados por 500 vezes com banhos a $4^{\circ} \mathrm{C}$ e $60^{\circ} \mathrm{C}$ e colocados em fucsina básica a $2 \%$ por 24 horas. A extensão da infiltração nas margens oclusais foi, geralmente, menor que nas cervicais e as restaurações confeccionadas pelas técnicas incrementais demonstraram menor infiltração cervical que as realizadas com incremento único.

Um estudo do efeito da ciclagem térmica imediata e mediata no vedamento marginal de restaurações de classe V com resina composta foi realizado por CRIM $^{33}$ em 1989. Preparos cavitários de classe $\mathrm{V}$, com margens cervicais em cemento/dentina, foram realizados nas superfícies vestibulares e linguais de molares humanos extraídos, os quais foram divididos em dois grupos de acordo com os sistemas adesivos empregados, Gluma e Scotchbond 2. Metade dos dentes de cada grupo foram termociclados imediatamente após a confecção das 
restaurações e os demais foram submetidos ao mesmo procedimento após 7 dias de armazenamento em água. Um grupo adicional foi restaurado usando um adesivo fotopolimerizável ( Scotchbond LC ). O autor concluiu que não houve diferenças significativas entre os adesivos empregados e que a microinfiltração foi similar nos dois períodos de termociclagem.

TORSTENSON; ODEN ${ }^{191}$, em 1989, analisaram o efeito dos tipos de agentes adesivos e de técnicas de inserção da resina na minimização das fendas oriundas da contração de polimerização ao redor das restauraçõe. Como material restaurador foram utilizadas as resinas Silar, P-10 e P-30 e, os agentes sistema de Bowen, Scotchbond e GLUMA, no tratamento das cavidades com estes diferentes agentes adesivos. Cavidades retangulares em superfícies proximais de pré-molares humanos foram preparadas, com as margens cervicais a $1.0 \mathrm{~mm}$ aquém da JCE, com 4.5 a $5 \mathrm{~mm}$ de altura, $3 \mathrm{~mm}$ de largura e $1.5 \mathrm{~mm}$ de profundidade na margem cervical e $2 \mathrm{~mm}$ na margem oclusal. Foram utilizadas as técnicas de inserção em incremento único , em dois incrementos ( podendo o primeiro ser inserido na região cervical ou oclusal ) e em três incrementos. Após a fotoativação e polimerização da resina composta, era aplicado um agente resinoso fluorescente ( Fluorescent Enamel Bond) nas margens oclusais e cervicais das restaurações. Desta forma, esta resina fluida com agente fluorescente penetraria através das fendas formadas. Então, as restaurações eram polidas e os dentes seccionados a fim de serem observados ao microscópio sob luz UV. Os resultados demonstram que, em geral, o agente fluorescente penetrou ao longo de todas as margens cervicais das restaurações e somente ocasionalmente atingiram a parede oclusal. Os menores valores de penetração deste agente foram encontrados na combinação do GLUMA com Clearfil Bonding Agent, demonstrando que tal combinação tem um bom potencial para 
suportar os estresses da contração de polimerização. Com relação às técnicas de inserção, a inserção em incremento único e em três incrementos não apresentaram redução nas fendas, enquanto que ambas técnicas em dois incrementos resultaram na redução da dimensão destas fendas, juntamente com a escolha correta do material.

PASHLEY ${ }^{151}$, em 1990, realizou uma abordagem sobre os aspectos clínicos relacionados à microinfiltração, como os fatores relativos à permeabilidade dentinária e suas variações de acordo com a espessura do tecido, diferenças regionais e a "smear - layer. Foram enfocados ainda os métodos de avaliação da microinfiltração e as dificuldades de correlação entre os resultados dos estudos “in vitro" com situações clínicas. Na oportunidade o autor sugeriu a utilização do cimento de ionômero de vidro como uma boa opção para prevenção da microinfiltração em restaurações com resina composta.

DONLY; WILD; JENSEN ${ }^{50}$, em 1990, estudaram comparativamente o comportamento de restaurações de classe II conservativas e convencionais com resina composta em molares humanos permanentes e decíduos extraídos. Cada dente recebeu duas preparações de classe II , uma MO e OD. Um cimento de ionômero de vidro foi usado como forrador em uma das cavidades e a outra foi forrada com cimento de hidróxido de cálcio. Todas as restaurações foram submetidas a cargas axiais de $17 \mathrm{~kg}$ por períodos de 5 segundos alternados com alívios de igual tempo, totalizando 12 ciclos durante 2 minutos. Em seguida, as amostras foram termocicladas com 40 banhos por dia a $10^{\circ} \mathrm{C}$ e a $40^{\circ} \mathrm{C}$, durante 30 dias com 2 minutos de permanência em cada banho. Logo após, foram novamente forçadas axialmente e imersas em solução aquosa de nitrato de prata a $50 \%$ para determinação da microinfiltração. Os resultados demonstraram menor infiltração marginal nas restaurações forradas com o 
cimento de ionômero de vidro, não havendo diferenças significativas entre os preparos conservativos e convencionais.

FEILZER; de GEE; DAVIDSON ${ }^{60}$, em 1990, avaliaram redução do estresse através do escoamento das resinas compostas ativadas quimicamente em relação à configuração cavitária. Foram estudadas cavidades de conhecidos valores de fator-C ( $0.5,2.0$, 2.5 e 5.0$)$. Os valores volumétricos da contração de polimerização forma determinados num período de 60 min através de um dilatômetro de mercúrio modificado. De acordo com os resultados pode-se concluir que a redução do estresse através do escoamento e esta capacidade de escoamento foi dependente tanto do material quanto da configuração cavitária. Os autores também concluíram que o escoamento de um material resinoso contribuiu grandemente com a redução do estresse de contração em restaurações com baixo valor de fator-C e foi insuficiente em cavidades em que este valor era alto.

Para KEMP-SCHOLTE; DAVIDSON ${ }^{102}$, um outro fator determinante das forças geradas pela contração das resinas compostas seria o módulo de elasticidade destes materiais. Assim sendo, em 1990, estudaram a influência desta propriedade sobre as tensões geradas durante a contração linear do material. De acordo com os autores, estas tensões expressam o produto da contração linear pelo módulo de elasticidade do material. Baseados em seus resultados, os autores puderam esclarecer que as resinas compostas com maior módulo de elasticidade desenvolvem maiores tensões durante a contração de polimerização e, caso não ocorra uma compensação, o resultado será a desadaptação da restauração. Por outro lado, o baixo módulo de elasticidade dos adesivos compensam boa parte destas tensões. Pelos resultados obtidos neste estudo, somente as resinas compostas possuidoras dessa característica 
obtiveram satisfatória adaptação marginal. A aplicação de uma resina fluida após o término da restauração forneceu um adequado selamento das margens das restaurações realizadas com uma resina de baixo módulo de elasticidade (Silux), enquanto para a resina composta P-30 aplicada em dentes posteriores isto não ocorreu. Conclui-se, portanto, que o módulo de elasticidade das resinas compostas influi significantemente na adaptação das restaurações.

Em 1990 EIDELMAN et al. ${ }^{56}$ estudaram a infiltração marginal em cavidades de classe II, totalmente restauradas com resina composta ou estas combinadas aos amálgama. Com tal finalidade, 20 (vinte) dentes pré-molares recém-extraídos foram convencionalmente preparados. Em dez, a margem gengival foi estendida à região de cemento, limitando-se os demais ao esmalte, a 1-2 mm aquém da junção amelo-cementária. O 1/3 cervical de uma das caixas proximais foi preenchido com amálgama (Silmet - Gyvatayim, Israel), após aplicação de um verniz cavitário, e o restante com resina composta (Marathon - Den. Mat.). Em seguida realizou-se o condicionamento ácido das paredes cavitárias e superfície do amálgama, aplicação do agente adesivo e preenchimento de toda a cavidade com resina composta. Todas as cavidades foram restauradas através da técnica incremental. Após submetidos a 1000 ciclos térmicos, nas temperaturas de $4^{\circ} \mathrm{C}$ e $60^{\circ} \mathrm{C}$, os dentes eram armazenados em solução corante de azul de metileno a $2 \%$ e solução de bórax por 24 horas e então seccionados no sentido longitudinal. As amostras foram observadas em um microscópio binocular (Model XT, Olympus, Tokyo, Japan ), avaliando-se a infiltração marginal pela profundidade de penetração do corante nas interfaces material restaurador/cemento, material restaurador/esmalte e entre os materiais restauradores e a formação de "gaps" nestas interfaces, sendo os resultados da microscopia estatisticamente analisados. Os autores observaram que o grau de infiltração na interface compósito-cemento foi significantemente 
maior que na interface compósito-esmalte e concluíram que a combinação resina compostaamálgama apresentou sucesso no controle da microinfiltração em cavidades em cavidades de classe II com término cervical em cemento.

Em 1990, CHAIN; BARATIERI; ARCARI ${ }^{31}$ publicaram um trabalho de atualização científica, abordando as conclusões oriundas de recentes pesquisas, focalizando os progressos de maior importância e de significado imediato na técnica do "sanduíche". Segundo os autores, esta técnica de modo geral está indicada para todas as cavidades que apresentam dentina exposta, inclusive nas de classe II, especialmente quando inexiste esmalte na margem cervical, desde que as restaurações de resina composta apresentando tais condições são caracterizadas por pobre adaptação marginal, originando sérias consequências, como por exemplo a recidiva de cárie. A ineficiência dos adesivos dentinários em bloquear a infiltração marginal enfatizou a necessidade do surgimento de uma técnica tal qual a do "sanduíche", que fosse capaz de resolver esse problema, minimizando ou eliminando a infiltração marginal. Essa técnica associa as vantagens inerentes aos cimentos ionoméricos às propriedades positivas das resinas à estrutura dental. Mas, por outro lado, é questionado se os ionômeros fotopolimerizáveis sofreriam o fenômeno de contração de polimerização, deslocando-se das paredes dentais, propiciando a infiltração marginal e consequentemente prejudicando sensivelmente o mecanismo de adesão. Concluindo, os autores relataram que as restaurações envolvendo o uso dos cimentos de ionômero de vidro associados às resinas compostas (técnica do "sanduíche"), mesmo possuidoras de certas desvantagens que dificultam a sua praticidade, ainda se apresentam como a melhor alternativa para bloquear a infiltração marginal em cavidades onde inexiste esmalte na margem cervical ou, quando esta for pobre em qualidade, representando a médio e longo prazo um benefício para a restauração. 
Ainda no ano de 1990 e com a mesma preocupação de uma série de outros pesquisadores, ou seja, tentar minimizar a microinfiltração e a formação de "gap" na margem cervical em cemento, resultantes da contração de polimerização da resina composta em cavidades esteticamente restauradas, TJAN; DUNN ${ }^{190}$ desenvolveram um estudo comparativo entre cimentos ionoméricos quimicamente ativados e cimentos ionoméricos modificados por resina (fotopolimerizáveis), aplicados em associação às resinas compostas, através da técnica do "sanduíche". Dois cimentos ionoméricos fotopolimerizáveis (XR-Ionomer e o Vitrebond ), um cimento ionomérico convencional ( Ketac-Bond ) e três resinas compostas ( Visio-Molar, Herculite XR e P-50) foram testados neste estudo. Cavidades de classe V padronizadas foram confeccionadas nas faces $\mathrm{M}$ e D de dentes molares recém-extraídos, totalizando 80 cavidades, distribuídas em 4 grupos experimentais: Grupo I (controle) - ácido poliacrílico 10\% / KetacBond / Visiomolar; Grupo II - XR-Ionomer / Herculite XR; Grupo III - ácido poliacrílico / XR-Ionomer / Herculite XR; Grupo IV - Vitrabond / P-50. O cimento ionomérico foi aplicado por toda a superfície dentinária, incluindo a margem gengival, formando uma camada de aproximadamente $0,5 \mathrm{~mm}$. Após restaurados, os dentes eram armazenados por 24 horas, sendo então as restaurações polidas com discos Sof-Lex. Cada forame apical foi obstruído com amálgama e a superfície externa do dente, com exceção de $1 \mathrm{~mm}$ na periferia da restauração, coberta por duas camadas de esmalte de unha. Por conseguinte, os dentes foram termociclados em solução de fucsina $0,5 \%$ nas temperaturas de $4^{\circ} \mathrm{C}$ e $55^{\circ} \mathrm{C}$, num total de 300 ciclos. Posteriormente, os espécimes foram seccionados longitudinalmente, sendo a extensão da microinfiltração avaliada microscopicamente em aumento de 100X. Um grau severo de microinfiltração foi observado em todos os espécimes do grupo I, minimizando-se significantemente nos demais grupos ( II , III e IV ), não ocorrendo diferença estatística entre 
estes. Com relação à microinfiltração, os autores concluiram que a remoção da smear layer pela aplicação do ácido poliacrílico não influenciou a ${ }^{*}$ performance ${ }^{*}$ dos cimentos de ionômero de vidro fotopólimerizáveis.

RUEGGEBERG $^{172}$, em 1991, realizou uma revisão de literatura reportando os fatores relevantes no que concerne ao substrato para testes de adesão à estrutura dentária. Foram discutidos aspectos como o substrato mais adequado para os testes, o efeito do tempo e da solução de armazenagem pós-extração dos dentes, o potencial de infecção destes dentes, o preparo da superfície anteriormente à aplicação do sistema adesivo e o efeito da profundidade do substrato dentinário. $\mathrm{O}$ autor conclui que há necessidade de um maior número de estudos para recomendar a substituição da utilização de dentes humanos pelos bovinos nos testes de adesão. Também afirma que não há evidências que provem de um tempo de armazenagem ideal dos dentes extraídos, mas recomenda um tempo máximo de 6 meses até mesmo por um motivo de padronização dos estudos.

MANDRAS; RETIEF; RUSSEL ${ }^{122}$ em 1991, avaliaram os efeitos dos estresses mecânico e térmico na microinfiltração de restaurações de classe $\mathrm{V}$ feitas com resina composta. Os espécimes foram divididos em quatro grupos, de acordo com os procedimentos empregados: grupo 1 - termociclado em corante $\left(250\right.$ ciclos, $\left.8-55^{\circ} \mathrm{C}\right)$; grupo $2-1000$ ciclos (duas séries de 500 ciclos com intervalo de 24 horas entre ambas); grupo 3 - termociclado em água (500 ciclos) e depois imerso na solução corante; grupo 4 - submetido a 66.000 aplicações de uma carga oclusal de $8 \mathrm{MPa}$ e posterior imersão em corante. Os resultados não mostraram diferenças significativas na microinfiltração entre os grupos termociclados, porém as amostras submetidas ao carregamento oclusal exibiram maior infiltração. 
STRATMANN; DONLY ${ }^{186}$, em 1991, avaliaram a microinfiltração em cavidades de classe II (MO e OD) restauradas com cermet e resina composta, cimento de ionômero de vidro convencional e resina composta ou apenas com cermet. Em metade dos preparos a parede gengival foi localizada em esmalte e na outra metade em dentina. Ambas as restaurações de cada dente foram submetidas a aplicações de cargas de $17 \mathrm{~kg}$ por períodos de 5 segundos, alternando com intervalos livres de igual tempo, totalizando 12 aplicações. Logo após, todas as amostras foram termocicladas a $5^{\circ} \mathrm{C}$ e $55^{\circ} \mathrm{C}, 20$ vezes por dia e durante 30 dias. Decorrido este prazo, foram novamente forçadas no sentido axial da mesma maneira descrita anteriormente e imersas em fucsina básica a $2 \%$ por 24 horas. Os resultados demonstraram que as restaurações combinadas exibiram menor microinfiltração.

No ano de 1991, LUNDIN; NORÉN ${ }^{116}$ estudaram a microinfiltração em restaurações de cavidades de classe II MO e OD em pré-molares humanos extraídos. As cavidades foram preparadas com as margens em esmalte apresentando profundidade, largura e altura médias de $2 \mathrm{~mm}$. Após os preparos, os dentes foram divididos em dois grupos, no primeiro grupo foi usado um cimento de hidróxido de cálcio como forramento e no segundo apenas um sistema adesivo de terceira geração. Metade das cavidades de cada grupo foi restaurada com uma marca de resina composta com $71 \%$ de carga e a outra com uma resina de $45 \%$ de carga em volume. Uma parte dos dentes restaurados foi submetida a um ciclo de aplicação de cargas com uma máquina especial para este fim. Cada restaurações foi submetida a 82 aplicações de 350 g de carga por minuto, durante 100 minutos em solução corante. A outra metade das restaurações (controle) permaneceu pelos mesmos 100 minutos imersa em corante sem sofrer esforço. Em seguida, todas as amostras foram seccionadas e a avaliação demonstrou uma 
considerável diferença na penetração do corante entre as restaurações submetidas a cargas (61\%) e as do grupo controle (30\%), os demais aspectos analisados ( material restaurador e forramento ) não demonstraram correlação direta significativa. Os autores concluíram que repetidas cargas aplicadas sobre restaurações de resina em dentes posteriores aumentam consideravelmente o risco de infiltração marginal.

Atentando-se à importância dos testes laboratoriais em se avaliar o desempenho dos materiais ou em se predizer o seu comportamento clínico, apesar de não ser possível extrapolar os resultados laboratoriais à prática clínica, RETIEF $^{165}$, em 1991, numa revisão da literatura analisou diversos fatores relevantes nos testes de adesão. Isto por que os testes variavam grandemente em suas metodologias, sem haver uma padronização que pudesse levar a comparações dos resultados. Segundo o autor, nem os testes de tração nem os de cisalhamento seriam capazes de simular as forças intrabucais. Preferencialmente, nos testes adesivos, deveriam ser utilizados dentes humanos extraídos armazenados adequadamente até 6 meses após a extração. Os dentes mais indicados para os testes seriam os primeiros e segundos molares permanentes superiores e inferiores totalmente irrompidos. Para testes de avaliação da microinfiltração, segundo o Acceptance Program for Dentin Adhesive Materials da American Dental Association, foi estipulado que, para materiais adesivos dentinários ( tipo 1), as cavidades deveriam localizar-se exclusivamente em dentina sem a confecção de retenções adicionais. Os procedimentos restauradores deveriam seguir as instruções dos fabricantes e a resina deveria ser inserida segundo a técnica incremental em dois incrementos oblíquos e os dentes deveriam ficar armazenados em água durante $24 \mathrm{~h}$ antes da termociclagem. Esta termociclagem deveria ser realizada em banhos de imersão em corante por, no mínimo 500 ciclos em temperatura entre +/- 8 graus Celcius e +/- 50 graus Celcius; e 
o tempo entre os banhos deveria ser de 2 minutos a 15 segundos. No entanto, quando da utilização da solução de nitrato de prata como agente traçador, o procedimento mais indicado seria o de termociclagem em água e posterior imersão.

MOMOI et al. ${ }^{130}$ em 1991 verificaram a infiltração marginal em espécimes restaurados com resina composta e submetidos a dois diferentes tipos de ciclagem térmica, o primeiro promovendo elevações de temperatura de $37^{\circ} \mathrm{C}$ para $60^{\circ} \mathrm{C}$ e outro, decréscimos de $37^{\circ} \mathrm{C}$ para $14^{\circ}$ C. A microinfiltração foi avaliada periodicamente, por um condutor elétrico, durante 10.000 ciclos térmicos. A infiltração ocorrida no primeiro teste foi maior que a registrada na segunda modalidade, levando os autores a concluir que repetidos estresse com elevação da temperatura podem provocar histerese da resina e consequentemente induzir o rompimento na interface dente-resina composta.

O trabalho publicado por BERTOLOTTI ${ }^{13}$, em 1991 relata que a contração de polimerização das resinas compostas consiste em fator limitante para a sua utilização em restaurações de classe II e que o emprego da técnica direcionada seria a solução para minimizar o estresse gerado por esta contração. Assim, este estudo apresentou como principal objetivo induzir a contração de polimerização mais em direção às paredes cavitárias do que para o centro da massa do material. Pelo exposto, a técnica restauradora sugerida para cavidades de classe II consiste no condicionamento ácido do esmalte e dentina, aplicação do sistema adesivo, inserção de uma resina química no terço cervical e, antes de sua completa polimerização, a complementação da restauração, com uma resina fotopolimerizável. Segundo o autor, esta técnica combina as vantagens de ser a resina composta quimicamente ativada inserida na região interna da cavidade com as vantagens oferecidas pelas resinas 
fotopolimerizáveis quando aplicadas na superfície externa. O direcionamento da contração de polimerização das resinas junto às paredes cavitárias resultaria em uma restauração com melhor adaptação marginal e mínima sensibilidade pós-operatória.

Ainda em 1992, um novo estudo foi realizado por FUSAYAMA ${ }^{72}$, vindo a confirmar o fato das resinas compostas quimicamente ativadas se polimerizarem inicialmente junto às paredes cavitárias, onde o maior aquecimento é promovido pela temperatura corpórea, ocasionando consequentemente a contração das mesmas em direção à estas paredes, aderindose a elas . As resinas fotopolimerizáveis, por sua vez, iniciam a polimerização junto às paredes cavitárias, contraindo-se em direção à camada superficial, tendendo à desadaptação. O autor cita trabalhos testando duas marcas de resinas de resinas auto e fotopolimerizáveis fabricadas pela Kuraray Co. e 3M (Clearfil, Silar, Photo-Clearfil e Silux), cujos resultados evidenciaram uma maior separação das paredes cavitárias quando da utilização das resinas fotopolimerizáveis, em função da irradiação oclusal, causando contração horizontal da camada superficial. O autor relata que em cavidades de classe III ou V com margem incisal ou oclusal em esmalte e margem gengival em dentina há maior tendência do material separar-se da margem dentinária. Isto porque a contração de polimerização da camada superficial mantida pela forte união do esmalte condicionado tende a ampliar ainda mais a separação da margem gengival dentinária e, consequentemente, a resina composta torna-se incapaz de prover um satisfatório selamento na margem gengival. Complementando, o autor sugeriu o uso de resinas fotopolimerizáveis apenas em cavidades pequenas e superficiais, confeccionadas nas faces vestibulares dos dentes, enquanto as cavidades profundas deveriam ser melhor restauradas com resinas compostas autopolimerizáveis aplicadas nas porções mais internas, assegurando adesão às paredes, em associação às resinas fotopolimerizáveis, 
preenchendo a porção mais externa, a fim de garantir estabilidade e estética. As resinas autopolimerizáveis devem ser preferidas ainda em cavidades cervicais, com margens em dentina ou cemento. Outras técnicas alternativas para vencer a contração de polimerização e a tendência de desadaptação da resina, são propostas neste estudo: a técnica incremental de inserção da resina, cujo método poderia amenizar tais problemas, mas não eliminá-los, ou o emprego do cimento de ionômero de vidro, aplicado nas paredes dentinárias, constituindo uma base para a resina composta.

O estudo “in vitro" desenvolvido por SIDHU; HENDERSON ${ }^{180}$, em 1992, apresentou por objetivo avaliar o grau de infiltração marginal em cavidades cervicais restauradas unicamente com resina composta ou pela técnica do "sanduíche". Cavidades de classe V padronizadas, com margens cervicais em cemento, foram confeccionadas na face vestibular de sessenta dentes molares humanos extraídos. Os dentes foram divididos em três grupos de vinte elementos cada, constituindo as seguintes condições experimentais: Grupo 1 - controle: Scotchbond 2 (3M) / Silux Plus (3M); Grupo 2 - Vitrabond (3M) / Scotchbond 2 / Silux Plus; Grupo 3 - Vitrabond (3M). Todas as restaurações foram submetidas aos procedimentos de polimento, com discos de granulações finas (Shofu Super-Snap Rainbow). Em seguida, os espécimes eram armazenados em água destilada por 24 horas. Após este período, metade dos espécimes de cada grupo foram termociclados (200 ciclos), nas temperaturas de $5^{\circ} \mathrm{C}$ e $55^{\circ} \mathrm{C}$, com permanência de 10 segundos em cada temperatura. Posteriormente todos os espécimes foram selados com cera utilidade e verniz, com exceção da restauração e $2 \mathrm{~mm}$ ao seu redor e armazenados por 24 horas em solução de fucsina básica a $0,5 \%$, em temperatura ambiente. Os espécimes foram seccionados longitudinalmente, sendo os cortes analisados em um microscópio de dissecção com aumento de 40 vezes. O grau de penetração do corante foi 
registrado através da atribuição de escores. Foi observada com maior frequência a ocorrência de microinfiltração nas margens gengivais para todos os tipos de restaurações, tendo sido, porém, significantemente menor para os grupos contendo cimento de ionômero de vidro modificado por resina.

Através de seus estudos, HIRSCHFELD et al. ${ }^{93}$, em 1992, verificaram a qualidade do selamento marginal em cavidades de classe II restauradas pela técnica do "sanduíche", utilizando dois tipos de cimento de ionômero de vidro reforçado por metal. Dentes molares extraídos foram convencionalmente preparados, possuindo a parede gengival de uma das caixas proximais margem em cemento, limitando-se a outra ao esmalte. Os dentes preparados foram restaurados com a resina composta Estilux Posterior ( $3 \mathrm{M}$ ), sendo as bases cervicais confeccionadas com o Ketac-Silver e com a Mistura Milagrosa. Após termociclagem e imersão em solução de fucsina $2 \%$, os dentes eram seccionados e a profundidade de penetração do corante avaliada nas interfaces ionômero-esmalte, ionômero-cemento e ionômero-resina composta. Após submetidos à análise estatística. os resultados evidenciaram um índice significante de infiltração entre as regiões de cemento e de esmalte, com maior ocorrência em cemento e maior grau de severidade para o Ketac-Silver. A infiltração marginal observada para a Mistura Milagrosa nas três interfaces não apresentou diferença estatística significante, sendo considerada suave. Os autores aprovaram as propriedades de selamento da Mistura Milagrosa empregada para restaurar cavidades de classe II pela técnica do "sanduíche".

PALMER; BARCO; BILLY ${ }^{150}$ em 1992, determinaram as temperaturas extremas que podem ser alcançadas, dentro de um limite de tolerância, nas superfícies dos dentes pela 
ingestão de substâncias quentes e frias. As temperaturas foram registradas com auxílio de um condutor ( colocado junto às superfícies de molares e incisivos inferiores de 13 indivíduos) o qual foi acoplado a um termômetro digital. Pela análise dos resultados, estes autores sugeriram o uso das temperaturas de $0^{\circ} \mathrm{C}$ e $67^{\circ} \mathrm{C}$ como limites para os testes de termociclagem com materiais odontológicos.

WENDT; McINNIES; DICKINSON ${ }^{200}$, em 1992, desenvolveram estudo para avaliar o efeito da termociclagem, em temperaturas clinicamente relevantes, sobre a análise da microinfiltração de restaurações em resina composta. Foram confeccionadas restaurações MOD em molares humanos hígidos extraídos, com uma margem cervical em esmalte e outra em cemento. As cavidades foram divididas em 5 grupos: GA - espécimes não termociclados e armazenados em fucsina básica a 5\% durante 24 horas a 37 graus Celcius; GA - espécimes não termociclados e armazenados em fucsina básica a $0.5 \%$ durante 4 horas; GB - espécimes termociclados e imersos em fucsina por 24 horas; GB - espécimes termociclados e imersos em fucsina por 4 horas; GC - espécimes termociclados em fucsina básica a 0,5\%. A termociclagem consistiu de 250 ciclos com banhos de 15 s cada em temperaturas de 5 graus a 55 graus Celcius. De modo geral, todas as restaurações demonstraram infiltração. O GB apresentou diferença estatisticamente significante comparado aos demais grupos, em relação à infiltração marginal do esmalte oclusal. Não houve diferença entre GA e GC. Não houve diferença entre os grupos quando da análise das margens em cemento. Quando os dados foram comparados de modo geral entre os dentes ( infiltração total de cada dente ), GB demonstrou um maior grau de infiltração do que os demais grupos. Pode-se notar que não houve diferença entre termociclagem em imersão em corante ou água. Desta maneira, os resultados sugerem que termociclar os espécimes para teste de microinfiltração, com o 
propósito de analisar os efeitos do coeficiente de expansão térmica em resina composta, não tem relevância. O número de ciclos deveria ser determinado de acordo com o número de variáveis a serem analisadas.

RIGSBY et al. ${ }^{169}$, no ano de 1992, determinaram a microinfiltração em restaurações de classe V, usando um sistema adesivo de terceira geração (XR Bonding System ) e uma resina composta ( Herculite XR ), em molares humanos extraídos com as margens oclusais em esmalte e as cervicais em cemento. Os dentes restaurados foram armazenados em solução fisiológica por 24 horas, quando as restaurações foram polidas e os espécimes novamente imersos na mesma solução por 7 dias. Logo após este período, foram divididos em 3 grupos de acordo com a condição experimental aplicada, assim um primeiro grupo de amostras foi termociclado em fucsina básica a $0,5 \%$ por 500 vezes com banhos de 15 segundos a $8^{\circ} \mathrm{C}$ e $50^{\circ}$ C; um segundo grupo foi submetido à aplicação de 60000 cargas oclusais de $34 \mathrm{MPa}$ em corante à temperatura de $37^{\circ} \mathrm{C}$ e o último grupo foi submetido às cargas oclusais e à termociclagem logo em seguida. $\mathrm{Na}$ avaliação dos resultados, nenhuma restauração demonstrou microinfiltração nas margens em esmalte; nas margens em cemento, a infiltração marginal foi similar nos grupos submetidos a apenas um tipo de estresse e foi significativamente aumentada nos dentes que receberam aplicação de cargas e também a termociclagem. Após, os espécimes foram imersos em fucsina básica a 0,5\% por 24 horas e seccionados ao centro para avaliação. A microinfiltração em esmalte foi praticamente nula. Nas margens em cemento/dentina, o grupo controle exibiu o menor grau de infiltração e não houve diferenças significativas entre os espécimes ciclados e não ciclados de um mesmo grupo. 
Nesse mesmo ano, RETIEF; McCAGHREN; RUSSEL ${ }^{168}$ realizaram um estudo "in vitro”, com a finalidade de determinar a microinfiltração cervical em restaurações classe II estéticas de resina composta, associada ao emprego de um cimento de ionômero de vidro modificado por resina (Vitrebond). Trinta cavidades tipo MOD foram confeccionadas em dentes pré-molares extraídos, com extensão cervical a aproximadamente $1 \mathrm{~mm}$ aquém da junção amelocementária na caixa mesial e, a $1 \mathrm{~mm}$ aquém na caixa distal. Em quinze preparos, toda a superfície dentinária foi coberta por uma fina camada de Vitrebond, até as proximidades da margem gengival, e para uma fina camada de Vitrebond, até as proximidades da margem gengival, e para as demais, a camada do ionômero estendeu-se ao ângulo cavosuperficial. Os passos seguintes para todas as amostras consistiram no condicionamento com ácido fosfórico à 37\%, inclusive da superfície ionomérica, seguido pela aplicação do sistema adesivo Scothbond 2, e preenchimento da cavidade com a resina composta P-50 por meio da técnica incremental. Os espécimes eram armazenados em solução fisiológica à $37^{\circ} \mathrm{C}$ por uma semana. Para os procedimentos seguintes, os dentes foram envolvidos por duas camadas de esmalte de unha, com exceção da restauração e $1 \mathrm{~mm}$ ao seu redor. Assim, sucedeu-se o tratamento térmico e em seguida imersão em solução de fucsina básica a 0,5\%. Cinco cortes correspondentes a cada espécime foram microscopicamente analisados a magnitude de $50 \mathrm{X}$. Desta maneira, a profundidade de penetração do corante nas margens gengivais foi avaliada através de escores, relevando um índice significantemente menor de infiltração cervical na região de esmalte, o qual reduziu-se consideravelmente, apresentando diferença estatística significante, quando a camada de cimento ionomérico estendia-se ao ângulo cavosuperficial, tanto na interface ionômero / esmalte quanto na interface ionômero / cemento. 
No ano de 1992, PACHECO; CONCEIÇÃO; SUFFERT ${ }^{148}$ avaliaram a influência dos ionômeros de vidro fotopolimerizável e convencional na infiltração marginal de restaurações de classe V com um sistema adesivo de terceira geração ( Scotchbond 2 ) e uma resina composta ( Silux Plus ). Foram utilizados 15 molares humanos extraídos, os quais foram divididos em 3 grupos de acordo com o material empregado. No primeiro grupo (controle) utilizou-se apenas o adesivo; no segundo um cimento de ionômero de vidro convencional ( Vidrion F ) e no terceiro um ionômero fotopolimerizável ( Vitrebond) antes da aplicação do sistema adesivo e da resina composta. Após restaurados, os dentes foram submetidos a 100 ciclos térmicos com banhos de 60 segundos a $5^{\circ} \mathrm{C}, 37^{\circ} \mathrm{C}$ e $60^{\circ} \mathrm{C}$ e, então imersos em azul de metileno a $0,5 \%$ a $37^{\circ} \mathrm{C}$ por 72 horas. Os autores concluíram que nenhum dos materiais foi capaz de eliminar totalmente a microinfiltração na parede cervical; as associações ionômero de vidro/resina composta promoveram um melhor vedamento marginal com resultado superior para o ionômero convencional.

Em 1992 MOUNT; PAPAGEORGIOU; MAKINSON ${ }^{141}$ pesquisaram “in vitro” o desempenho da técnica do "sanduíche", proposta por Mc Lean et al em 1985, quanto ao selamento marginal, utilizando novos materiais. Cavidades de classe V com margem oclusal em esmalte e gengival em dentina foram preparadas nas superfícies vestibular e lingual de vinte e quatro dentes molares extraídos e somente na face vestibular de dez dentes correspondentes aos espécimes-controle. Os vinte e quatro dentes foram divididos em dois grupos de estudo: 1 - cavidades restauradas com Ketac-Bond, superficialmente desgastadas para receber uma faceta de resina composta; 2 - cavidades restauradas após a confecção de uma base de cimento ionomérico ( Vitrebond). Dos dez dentes mantidos como controle, cinco foram restaurados com o Chemfil e cinco com Fuji II. Para todas as restaurações, utilizou-se a 
resina composta Superlux Solar, com a inserção de dois incrementos, iniciando pela margem oclusal. Após restaurados, os espécimes foram estocados em água por um período de duas semanas e posteriormente termociclados nas temperaturas de $5^{\circ} \mathrm{C}$ e $55^{\circ} \mathrm{C}$, com permanência de 30 segundos em cada uma, totalizando 500 ciclos. Antes de serem inseridos na solução de vermelho de preceína, na qual permaneceriam por trinta minutos, os dentes foram protegidos com duas camadas de esmalte de unha, exceto a área restaurada. Após seccionados, os espécimes foram avaliados quanto à microinfiltração, através da atribuição de escores aos diferentes índices de penetração do corante. Das vinte e quatro restaurações do primeiro em regiões onde a espessura de material era fina e este acabou sendo removido da superfície dentinária, pela contração de polimerização da resina. Resultados semelhantes aos do grupo 1 foram observados no grupo 2 , e ao serem examinadas as áreas infiltradas, verificou-se penetração do corante somente em regiões bem próximas às margens das restaurações.

TAYLOR; LINCH $^{189}$, em 1992, discutiram os diversos métodos de estudo da microinfiltração através de uma revisão de literatura. Comentaram sobre o método de ar comprimido, estudos através da utilização de bactérias, uso de radioisótopos, análise através de nêutrons, estudos eletroquímicos, microscopia eletrônica de varredura, ciclagem térmica e mecânica, utilização de traçadores químicos e da penetração de corantes. Comentaram que os ciclos térmicos utilizados na termociclagem variam bastante entre os autores, porém não existia muitos estudos relatando a variação térmica normal no ambiente bucal, e que esta variação seria, provavelmente, menor do que a difusão da temperatura no interior dos materiais estudados. Com relação à utilização dos traçadores químicos, comentou-se que sua diferença e dos outros corantes reside no fato de que os agentes traçadores são substâncias que reagem entre si, e ambas penetram nas fendas entre a restauração e o dente. Geralmente é 
utilizado uma solução de nitrato de prata a 50\%, na qual é imerso o espécime a ser estudado, e subseqüentemente este é colocado numa solução reveladora. Esta técnica foi relatada como sendo a segunda mais utilizada após o uso de corantes. Reportaram que a imersão em nitrato de prata é precisa uma vez que o íon tem um diâmetro extremamente pequeno ( $0,059 \mathrm{~nm})$ se comparado ao tamanho de uma bactéria padrão ( 0,5 - 1,0 um ). Por fim, relataram o uso de corantes como sendo o método mais popular no estudo da microinfiltração. No entanto, tratase de um método altamente sensível e a interpretação de seus resultados deve ser feito de forma padronizada, a qual é feita, normalmente, através de um sistema de escores, o que é muito subjetivo. Os corantes mais frequentes utilizados são as soluções de fucsina básica, particularmente aquelas em propileno glicol. Logo, pode-se notar que existem diversos métodos para demonstrar a microinfiltração dos materiais, cada qual com suas vantagens e desvantagens. Esta gama de opções conduz a uma falta de padronização entre os estudiosos, tornando-se difícil comparar técnicas semelhantes. Tentativas foram realizadas para desenvolver um sistema de medição padrão, pois este ainda é muito subjetivo.

Considerando a ineficiência das restaurações de resina composta em selar eficazmente as regiões de dentina e cemento e na tentativa de solucionar esse problema, MELLO; CUNHA; CONCEIÇÃO ${ }^{126}$ em 1992 desenvolveram um estudo com o objetivo de avaliar "in vitro" a microinfiltração nas associações ionômero fotopolimerizável / resina composta e amálgama / resina composta, comparativamente a restaurações somente de resina composta. Cavidades de classe II próximo-oclusais padronizadas, apresentando a margem gengival estendida além da junção amelocementária, foram preparadas em trinta dentes molares permanentes extraídos. Os dentes preparados foram divididos em três grupos de dez elementos cada, conforme os materiais restauradores utilizados: Grupo I ( controle ) - Prisma 
Universal Bond 3 / Prisma APH; Grupo II - Vitrebond / Prisma Universal Bond 3 / Prisma APH; Grupo III - True Dentalloy II / Prisma Universal Bond 3 / Prisma APH. Para todos os grupos, a resina foi inserida pela técnica incremental. Logo após a confecção de cada grupo de restaurações, foi realizado o acabamento com pontas diamantadas ultra-finas e tiras de lixa e posteriormente os espécimes foram submetidos a 100 ciclos térmicos, de um minuto cada, nas temperaturas de $5^{\circ} \mathrm{C}, 37^{\circ} \mathrm{C}$ e $60^{\circ} \mathrm{C}$. Os dentes foram então protegidos com esmalte de unha, deixando livre a restauração e uma faixa de $1 \mathrm{~mm}$ ao redor desta, e em seguida imersos em solução corante azul de metileno a $0,5 \%$ e mantidos durante 72 horas, numa estufa à $37^{\circ} \mathrm{C}$. Os dentes eram seccionados no sentido mésiodistal, sendo os cortes avaliados em uma lupa estereoscópica com aumento de $25 \mathrm{X}$. A leitura da penetração do corante foi realizada através da atribuição de escores. Todas as restaurações apresentaram microinfiltração na margem cervical, não havendo diferenças estatisticamente significantes entre as condições experimentai .

PERETI NETO ${ }^{154}$, em 1992, verificou “in vitro” a deformação elástica e a infiltração marginal de restaurações MOD, com as resinas compostas P-50, Adaptic II P, Estilux P e Isosit SR, submetidas à força de compressão. Foram realizados preparos cavitários padronizados em 80 molares humanos extraídos, os quais foram divididos em 4 grupos de acordo com o material restaurador utilizado. Dez amostras de cada grupo foram armazenadas em água destilada a $37^{\circ} \mathrm{C}$, por 7 dias, em seguida foram imersas em fucsina básica a $0,5 \%$ por 10 minutos, lavadas e seccionadas para avaliação. Outros 10 dentes restaurados de cada grupo foram submetidos à força de compressão de $17 \mathrm{~kg}$ e $1 \mathrm{~kg}$ alternadamente, por 30 segundos, 10 vezes, durante 6 dias. A cada aplicação de carga foram feitas medidas de deformação das restaurações, com um microscópio comparador. No sétimo dia as cargas foram aplicadas com 
os espécimes imersos em corante, os quais foram lavados e seccionados para avaliação da microinfiltração. Os resultados demonstraram aumento da infiltração no grupo restaurado com P-50/Scotchbond II após a aplicação das cargas.

DAVIDSON; ABDALLA ${ }^{41}$, já no ano de 1993, avaliaram “in vitro” a microinfiltração, pela penetração de corante, e a integridade marginal, por observação em microscopia eletrônica de varredura, de restaurações de resina composta em cavidades de classe II. Foram utilizados 96 dentes humanos extraídos, os quais foram divididos em 6 grupos, usando 3 sistemas adesivos ( Heliobond, Scothbond 2 e Clearfil Photo Bond ) e a combinação de cada um destes com um ionômero de vidro ( Vitrebond ). Metade das amostras de cada grupo foi submetida a termociclagem ( 500 ciclos de banhos a $5^{\circ} \mathrm{C}$ e $55^{\circ} \mathrm{C}$ ) e a cargas axiais ( 4000 aplicações de 12,5 kg ) com imersão simultânea em azul de metileno. As demais amostras foram imersas por 24 horas neste corante. A aplicação de estresse térmico e mecânico aumentou a infiltração nos espécimes restaurados com resina composta e sistema adesivo, nos grupos que receberam o forramento com Vitrebond a aplicação dos dois tipos de estresse não provocou alteração na integridade marginal das restaurações.

BARNES et $\mathrm{al}^{7}$ em 1993 avaliaram a microinfiltração marginal em restaurações de resina composta classe $\mathrm{V}$, comparando dois sistemas adesivos empregados ( Prisma Universal Bond 2 e 3 ) e o comportamento das restaurações realizadas "in vivo" e "in vitro". As amostras testadas "in vivo" foram extraídas em torno de 6 semanas após a realização das restaurações. Para o estudo “in vitro”, os espécimes foram termociclados 540 vezes com banhos a $5^{\circ} \mathrm{C}$ e $55^{\circ} \mathrm{C}$. Após a extração e a termociclagem, todas as amostras foram imersas em nitrato de prata, seccionadas e examinadas ao microscópio. Os resultados demonstraram 
não haver diferenças significativas entre os sistemas adesivos empregados e que as restaurações testadas "in vitro" exibiram significantemente mais infiltração que as testadas "in vivo".

PRATI et al. ${ }^{160}$, em 1994, avaliaram longitudinalmente a microinfiltração em restaurações de classe II realizadas com 3 diferentes combinações de sistemas adesivos e resinas compostas $($ Tripton + Occlusin, Vitrebond + Scotchbond $2+$ P-50 e Clearfil Photo Bond + Clearfil Photo Posterior ) em vários intervalos de tempo ( imediatamente à inserção até 10 meses após ), submetendo as amostras à aplicação de carga oclusal. Uma segunda proposição do trabalho foi a comparação entre a infiltração determinada por fluído sob pressão com determinada pela penetração de uma substância através de interface. Para tal, utilizaram 36 terceiros molares humanos extraídos, os quais tiveram as raízes seccionadas 2 mm abaixo da junção cemento-esmalte e todo o tecido pulpar foi removido. Os segmentos coronários resultantes foram fixados sobre uma placa e conectados a um aparato de pressão. A câmara pulpar de cada dente foi preenchida com uma solução fisiológica fosfatada para os testes de infiltração. Preparos cavitários MOD foram realizados com as paredes gengivais de ambas caixas proximais em dentina. Após os preparos, o fluido foi acionado e a permeabilidade da dentina foi registrada. As cavidades foram, então, restauradas seguindo as especificações dos fabricantes de cada material empregado. Após as restaurações, a permeabilidade foi medida em intervalos de 15, 45 e 150 minutos; 1 e 2 dias; 1 e 2 semanas; 1,2,3 e 10 meses. No período de 3 meses, todos os espécimes foram termociclados por 240 vezes entre $4^{\circ} \mathrm{C}$ e $55^{\circ} \mathrm{C}$ com 30 segundos de imersão em cada banho. Em seguida foram novamente conectados ao aparelho e a permeabilidade foi registrada. As amostras foram, então, submetidas a 1.440 ciclos térmicos e uma segunda avaliação da permeabilidade foi 
realizada. Ao final de 10 meses de armazenamento, os espécimes foram submetidos a um ciclo de aplicação de carga oclusal, com 100 aplicações de 17 kg por 10 segundos cada. Após as cargas, as amostras foram imersas em nitrato de prata a $50 \%$ e seccionadas para avaliação ao microscópio óptico. Os resultados demonstraram um alto índice de microinfiltração imediatamente após a confecção das restaurações comparando com períodos de 1 e 2 dias. Após 1 e 2 meses, todas as restaurações exibiram aumento da permeabilidade, sugerindo que a expansão higroscópica não foi suficiente para acompanhar os passos da degradação hidrolítica. Nem a termociclagem e nem o estresse oclusal aumentou a microinfiltração na metodologia aplicada. Os autores destacaram, ainda, que a microinfiltração pode ser detectada por ambos os métodos empregados, fluido sob pressão e penetração de nitrato de prata, com as vantagens e limitações inerentes a cada técnica.

Uma avaliação da microinfiltração em restaurações de resina composta de classe V utilizando dois sistemas adesivos de quarta geração foi realizada por LINDEN; SWIFT JUNIOR $^{114}$, em 1994. Outros dois grupos de dentes foram avaliados, um sem utilização de agente de união e outro com um sistema adesivo de terceira geração, para efeito comparativo. Neste estudo foram utilizados 40 pré-molares humanos recentemente extraídos, nos quais foram preparadas cavidades de classe $\mathrm{V}$ com as margens cervicais em cemento/dentina. No grupo controle as margens de esmalte foram condicionadas com ácido fosfórico a 37\%, lavadas, secadas e as restaurações realizadas sem a utilização de agente de união; no segundo grupo foi utilizado o Scothbond 2 (terceira geração); no terceiro utilizou-se o Scothbond Multi-Uso e no último o All-Bond 2 ( ambos de quarta geração). Metade das cavidades de cada grupo foi preenchida com incremento único da resina Silux Plus e a outra metade com dois incrementos. Todas as restaurações foram acabadas e polidas 30 minutos após concluídas 
e armazenadas por 24 horas . Em seguida as amostras foram submetidas a 300 ciclos térmicos com banhos de 30 segundos a $5^{\circ} \mathrm{C}$ e $55^{\circ} \mathrm{C}$. Estas foram, então, imersas em uma solução de nitrato de alumínio a $50 \%$ por 2 horas, lavadas com água destilada por 5 minutos e colocadas em solução fotorreveladora sob luz fluorescente por 6 horas. A microinfiltração foi avaliada ao microscópio ótico após seccionamento dos espécimes. Nenhuma infiltração foi detectada nas margens de esmalte; as restaurações realizadas pela técnica incremental e em incremento único foram equivalentes, exceto no grupo controle onde a primeira exibiu menos infiltração; o All-Bond 2 demonstrou significativamente menor infiltração que o Scothbond 2 e o grupo controle.

RETIEF $^{166}$, também em 1994, elaborou uma revisão a respeito da capacidade de vedamento marginal das restaurações de resina composta realizadas em associação com sistemas adesivos. Abordando os principais fatores que podem influenciar este vedamento, o autor destacou que: a contração de polimerização sofrida pelas resinas compostas produz forças capazes de alterar a união adesiva entre o material restaurador e as paredes cavitárias permitindo infiltração pela interface; a absorção de água pela restauração exposta ao ambiente bucal melhora a adaptação, mas não é capaz de restabelecer a união; a diferença do coeficiente de expansão térmica entre o dente e o material restaurador é um importante fator coadjuvante para a formação de fendas marginais; nenhum sistema adesivo é capaz de eliminar completamente a microinfiltração em paredes desprovidas de esmalte; a exposição dos dentes ao estresse mastigatório “in vivo" ou a aplicação de carga oclusal nos testes "in vitro" promovem aumento da microinfiltração e o retardo do acabamento e polimento colaboram consideravelmente para a redução das dimensões das fendas marginais. 
DAVIDSON; ABDALLA ${ }^{41}$, neste mesmo ano, avaliaram o efeito da aplicação de carga oclusal na integridade marginal de restaurações adesivas cervicais em molares humanos extraídos. Para tal, cavidades de classe V com paredes gengivais em cemento/dentina foram preparadas nas faces linguais ou vestibulares dos dentes e restauradas com um dos seguintes produtos ou associações a seguir: 1 -Ketac-Fil; 2- Fuji II LC; 3- Ketac-Bond/Pertac; 4Photac-Bond/Pertac; 5- Scothbond 2/P-50; 6- Scothbond Multi-Uso/P-50; 7- Clearfil Liner Bond/Clearfil Photo Posterior e 8- Optibond/Herculite XR. As amostras de todos os grupos foram divididas de acordo com os procedimentos empregados, assim o procedimento A (controle) constou de imersão dos espécimes em azul de metileno a 2\% por 24 horas; o procedimento B compreendeu 5000 ciclos de aplicações de uma carga de $125 \mathrm{~N}$ e o procedimento C 5000 aplicações de $250 \mathrm{~N}$ ( somente nos grupos que não foram afetados pela carga de 125 N.) Durante as aplicações das cargas, as amostras foram mantidas em azul de metileno, permanecendo neste por 24 horas após a realização do teste. Todos os dentes foram seccionados e a penetração do corante na parede gengival foi avaliada por escores. Os resultados revelaram que : no procedimento controle apenas os grupos $2,6,7$ e 8 demonstraram perfeita integridade marginal; após as cargas de $125 \mathrm{~N}$ os grupos 1,3 e 5 mostraram um significativo aumento da infiltração e o aumento do valor da carga não foi capaz de afetar apenas os grupos 6 e 7.

ELIADES $^{57}$ realizou, no ano de 1994, uma revisão a respeito da importância clínica da formulação dos sistemas adesivos e dos testes “in vitro" propostos para avaliação destes sistemas. Segundo o autor, os vários protocolos experimentais podem servir de base no estudo dos materiais, mas sua revelância para o desempenho clínico é desconhecida. Com relação à microinfiltração especificamente, o mesmo afirmou não haver correlação direta entre 
trabalhos "in vitro" e o desempenho clínico e que os resultados devem ser analisados em um "nível teórico de infiltração" que pode ( ou não ) ocorrer "in vivo". Aceitando o teste de infiltração como um parâmetro importante para o uso clínico dos sistemas adesivos, o autor advertiu para a necessidade de uniformização das diversas variáveis envolvidas como os tipos e as dimensões das cavidades, técnica de restauração, tipo de material restaurador, procedimentos de acabamento e polimento, tipo de demarcador, dentre outras.

Também em 1994 FUTATSUKI; NAKATA ${ }^{73}$, desenvolveram um estudo "in vitro", avaliando a microinfiltração marginal em restaurações classe II de resina composta. As cavidades foram preparadas em quarenta dentes pré-molares humanos extraídos, livres de cáries, as quais foram restauradas com diferentes materiais, constituindo quatro grupos experimentais: 1 - Occlusin / Bonding Agent; 2 - Palfique Light-S / Light Bond; 3 - P-50 / Dentin Primer / Scotchbond 2; 4 - P-50 / Vitrabond /Scothbond 2. Durante os procedimentos restauradores, além dos dentes preparados um outro pré-molar foi utilizado para reproduzir o contato proximal, com o objetivo de simular uma condição clínica. Para a inserção dos materiais, foram empregadas matrizes e cunhas refletivas. Doze horas após o término das restaurações, estas foram submetidas aos procedimentos de acabamento e polimento, sofrendo imediatamente após um tratamento térmico correspondente a 100 ciclos, nas temperaturas de $4^{\circ} \mathrm{C}$ e $60^{\circ} \mathrm{C}$. Em seguida, os dentes foram imersos em solução de fucsina básica a $0,5 \%$, por 24 horas a $37^{\circ} \mathrm{C}$. Após o seccionamento dos dentes, os cortes foram analisados em um microscópio óptico com aumento de 30-40 vezes. A avaliação da profundidade de penetração do corante foi realizada através do critério numérico de escores. Os autores observaram a ocorrência de um maior grau de microinfiltração na margem cervical em comparação à margem oclusal. Entretanto, notou-se uma melhora significante do selamento marginal 
gengival, com o uso do adesivo dentinário bem como dos demais métodos testados, em relação ao adesivo convencional para esmalte (Bonding Agent ). Os resultados indicaram, ainda, que o cimento de ionômero de vidro modificado por resina, utilizado como base forradora, impediu a penetração do corante na dentina, embora tenha ocorrido infiltração ao nível do esmalte em todos os elementos componentes deste grupo.

A afinidade micromorfológica entre a dentina e dois sistemas adesivos "in vivo" e "in vitro" foi avaliada por FERRARI ${ }^{65}$ em 1994. Para avaliação "in vivo" foram utilizados 10 incisivos com extração indicada por doença periodontal severa, nos quais foram preparadas cavidades de classe V com margens cervicais em cemento/dentina. Metade dos preparos foi restaurada com Gluma 2000 e Pekafil e a outra metade com Scothbond Multi-Uso e Z-100. Vinte e quatro horas após a confecção das restaurações os dentes foram extraídos e armazenados em cloramina a $1 \%$ à temperatura ambiente. Para o estudo "in vitro" foram utilizados 10 incisivos recentemente extraídos que foram preparados e restaurados seguindo os mesmos passos citados anteriormente. Todos os dentes foram imersos em uma solução de ácido hidroclorídrico a $30 \%$ por 2 dias para eliminar a estrutura mineral e permitir a observação. A superfície remanescente foi coberta com ouro e observada ao microscópio eletrônico de varredura. Não houve diferenças morfológicas entre os espécimes restaurados "in vivo" com os restaurados "in vitro", bem como não houve diferenças ente os sistemas adesivos empregados. $\mathrm{O}$ autor enfatizou a necessidade de futuras pesquisas usando um maior número de dentes e diferentes sistemas adesivos para validar a correlação entre os estudos "in vivo" e "in vitro". 
CHAN; GLYN JONES ${ }^{29}$, em 1994, realizaram um estudo a fim de determinar o significado da ciclagem térmica na microinfiltração em 4 diferentes técnicas de restauração de cavidades radiculares. Para o trabalho, cavidades de classe V foram preparadas nas superfícies mesiais, distais, vestibulares e linguais das raízes de pré-molares humanos extraídos. Cada cavidade de um mesmo dente foi restaurada com um material diferente após escolha aleatória. Nas primeiras cavidades foi utilizado amálgama; na segunda partida um cimento de ionômero de vidro ( Ketac-Fil ); na terceira utilizou-se a associação do sistema adesivo Tripton com a resina híbrida Opalux e nas últimas cavidades a associação do Gluma com a resina de micropartículas Pekalux. Os dentes restaurados foram armazenados em solução fisiológica por 24 horas e então metade destes foi termociclada e a outra metade permaneceu à temperatura ambiente. Em seguida todas as amostras foram armazenadas em solução fisiológica por uma semana e imersas em eosina a 5\%. Os espécimes foram seccionados através de suas restaurações e a microinfiltração foi avaliada por escores após exames ao microscópio. Todos os materiais exibiram infiltração. Quando os espécimes ciclados e não ciclados foram comparados não houve diferenças estatisticamente significativas, levando a crer que a termociclagem não influenciou na microinfiltração.

CRIM; CHAPMAN ${ }^{34}$, em 1994, verificaram a influência na redução da microinfiltração de 4 métodos de restauração de cavidades classe II com resina composta. Neste estudo foram empregados 20 molares humanos extraídos, nos quais foram confeccionadas duas cavidades de classe II, uma MO e outra OD. Os dentes foram divididos em 4 grupos de acordo com a técnica e os materiais utilizados, assim o grupo 1 foi restaurado usando um ionômero de vidro fotopolimerizável para forramento ( Fuji II LC ), o sistema adesivo de terceira geração Prisma Universal Bond 3 e a resina APH com uma matriz metálica; no segundo grupo foram 
empregados o mesmo sistema adesivo e resina usados no grupo anterior com uma matriz transparente e polimerização direcionada; o grupo 3 foi restaurado com estes mesmos materiais, mas com uma matriz metálica e no grupo 4 o sistema adesivo foi substituído por um agente de união ao esmalte e os demais itens foram os mesmos usados no grupo 3. Após as restaurações, os dentes foram armazenados em água a $37^{\circ} \mathrm{C}$ por 24 horas e então submetidos a 100 ciclos térmicos com banhos de 23 segundos a $37^{\circ} \mathrm{C}, 4$ segundos a $12^{\circ} \mathrm{C}, 23$ segundos a $37^{\circ} \mathrm{C}$ e 4 segundos a $54^{\circ} \mathrm{C}$ em água. Em seguida as amostras foram imersas em solução aquosa de fucsina básica por 24 horas, seccionadas ao meio e a microinfiltração foi medida em milímetros sob microscopia óptica. As restaurações realizadas com o agente de união convencional demonstraram severa infiltração; o uso do cimento de ionômero de vidro proporcionou o melhor vedamento marginal e os grupos 2 e 3 não apresentaram diferenças significativas entre si.

Uma avaliação da microinfiltração marginal em restaurações de classe V com resina composta , em função dos sistemas adesivos empregados, foi realizada por FORTIN; PERDIGÃO; SWIFT JUNIOR ${ }^{68}$, no ano de 1994. Neste estudo, cavidades de classe V foram confeccionadas nas superfícies vestibulares de 40 molares humanos extraídos, com as margens oclusais em esmalte e as cervicais em cemento/dentina. Os dentes preparados foram divididos em 4 grupos de 10, de acordo com os sistemas adesivos utilizados ( Optibond/Kerr; All-Bond 2/Bisco; Scothbond Multi-Uso/3M e Scothbond Dual-Cure/3M ). Após as restaurações, os espécimes foram armazenados por uma semana, e então termociclados e imersos em fucsina básica por 24 horas. A microinfiltração foi avaliada por escores, usando uma escala ordinal, após a secção dos espécimes. O Optibond demonstrou a menor parcela de infiltração nas margens de dentina, porém não foi estatisticamente superior aos demais. All- 
Bond 2 e Scothbond Multi-Uso tiveram significativamente mais infiltração que o Optibond e o Scotchbond Dual-Cure nas margens de esmalte.

ARAÚJO et al. ${ }^{3}$ já no ano de 1995 avaliaram o grau de infiltração na interface resina composta/cimento de ionômero de vidro e nas margens dentinárias em restaurações de classe V, realizadas em molares humanos extraídos, no limite amelo-cementário, com uma base de ionômero de vidro convencional ou fotopolimerizável. As superfícies das bases forradoras forma condicionadas, em metade das amostras, com ácido fosfórico a 37\%. Após as restaurações, todos os dentes foram termociclados e seccionados para avaliação. Os autores verificaram que não houve infiltração entre a resina restauradora e o ionômero de vidro fotopolimerizável (Vitrabond-3M) quando este foi condicionado, no grupo não condicionado a infiltração ocorreu em 60\% das amostras; para o ionômero convencional (Ketac-Bond) nas duas condições experimentais, com e sem condicionamento, a infiltração marginal ocorreu em cerca de $40 \%$ e $30 \%$ das amostras, respectivamente; a frequência de infiltração marginal entre os ionômeros e a dentina foi menor com o Vitrabond; as margens em esmalte não apresentaram infiltração.

No ano de 1995 , SILVA E SOUZA JUNIOR ${ }^{183}$ elaborou uma revisão sobre os adesivos dentinários. Segundo o autor, estes materiais podem ser classificados em 4 gerações de acordo com a sua evolução. Assim, os adesivos dentinários de primeira geração eram compostos por uma solução de ataque à base de ácido cítrico, para remoção da "smear layer", facilitando o contato do agente de união com a superfície dentinária. Mas, devido à natureza hidrofóbica destes sistemas o contato com a dentina úmida ficava comprometido, não havendo ligações adequadas. As falhas ocorridas nos adesivos de primeira geração eram 
devidas, principalmente, ao aumento da permeabilidade da dentina pela remoção da "smear layer", motivando o desenvolvimento de sistemas de adesão para serem aplicados diretamente sobre esta camada ( adesivos de geração 2 ), entretanto a força de adesão limitou-se à resistência coesiva da própria camada de esfregaço, com valores relativamente baixos. Devido aos pobres resultados alcançados com os adesivos de segunda geração, foram desenvolvidos sistemas que, de certa forma, atuavam sobre a "smear-layer" para que fosse facilitada a penetração de um monômero hidrofílico antes da aplicação do agente de união propriamente dito. Estes sistemas apresentavam "primers" que podiam ou não estar associados a condicionadores ácidos. Estes adesivos, denominados de terceira geração, atuam de diferentes maneiras, de acordo com o tratamento dado à "smear layer", assim existem sistemas que removem, substituem ou modificam a camada de esfregaço . Os adesivos de quarta geração removem, inicialmente, a "smear layer" descalcificando a dentina inter e peritubular e expondo as fibras colágenas para posterior impregnação desta área descalcificada por monômeros hidrofílicos. Uma grande vantagem de sua utilização seria a formação de uma área formada pela impregnação de um monômero com a superfície dentinária desmineralizada, resultando em uma camada ácido-resistente de dentina reforçada por resina, a qual é denominada de zona ou camada híbrida, que foi descrita por NAKABAYASHI ${ }^{(W W)}$ em 1982.

Considerando a capacidade do amálgama em oxidar e formar produtos que, resultantes de sua corrosão, se depositam na interface dente / restauração, promovendo assim o seu selamento, BEN - AMAR; CARDASH; JUDES ${ }^{11}$, em 1995, revisaram a literatura referente à efetividade do verniz cavitário em prevenir a microinfiltração nas restaurações de amálgama, até que o processo de corrosão ocorra. Os autores constataram que, desde que os amálgamas 
sejam bem condensados, adequadamente brunidos e polidos, tornam-se menos porosos e consequentemente sua corrosão ocorrerá mais lentamente. Observaram ser comum a existência de uma fenda na interface dente / restauração, com extensão aproximada de 10-15 um. Durante o processo de corrosão das ligas, as restaurações tornam-se mais suscetíveis à retenção de placa dental e por conseguinte de bactérias. Estes microorganismos utilizam o oxigênio da placa e das fendas, produzindo íons que irão diminuir o pH local. Os eletrólitos formados nestes locais possuem um $\mathrm{pH}$ mais baixo e assim propiciam um meio mais corrosivo ao amálgama. Caso este processo ocorra somente na superfície da restauração, é em parte neutralizado pela liberação de íons $\mathrm{Cl}$ - e $\mathrm{OH}$ - da saliva, mas devido às dimensões reduzidas das fendas a passagem de íons salivares por estas regiões torna-se dificultada. Observaram, também, existir uma correlação entre cárie secundária e corrosão do amálgama, a qual se deve ao aumento da acidez nas adjacências da restauração e à diminuição das fendas, aumentando, então, as chances de um selamento marginal com pequenas quantidades de produtos resultantes da corrosão. Este resultado pode ser conseguido através de alguns procedimentos clínicos básicos, como adequada condensação, correta manipulação do material, brunidura, e polimento das restaurações. Por meio desta revisão literária, os autores concluíram que as ligas com alto conteúdo de cobre se oxidam mais lentamente em comparação às ligas convencionais e, ainda exigem o uso de um verniz intermediário, com o propósito de vedar precocemente a interface dente / restauração até que os produtos de corrosão o façam, reconhecendo a existência de dúvidas sobre a sua eficácia, e que a corrosão dependerá de variações individuais na química dos fluidos bucais.

Em 1995 SIDHU; WATSON ${ }^{181}$, através de uma revisão, estudaram as características dos cimentos de ionômero de vidro modificados por resina. Esclareceram que estes materiais 
são híbridos do cimento de ionômero de vidro convencional com a resina composta fotopolimerizável, os quais apresentam consequentemente propriedades intermediárias dos dois materiais, com algumas características superiores as do cimento ionomérico convencional. Geralmente, possuem as vantagens de ambos os materiais que o originaram, como estética, adesão à estrutura dentária, liberação de flúor e polimerização rápida pela exposição da luz visível. Os verdadeiros cimentos de ionômero de vidro modificados por resina possuem fundamentalmente a reação de presa ácido-base, que permite a polimerização do material na ausência de luz, com acréscimo de um processo secundário de presa, o qual é fotoiniciado. Com relação à microinfiltração marginal, os autores relataram que os resultados de testes “in vitro" já realizados com estes materiais exibem resultados variáveis e nem todos demonstraram uma redução significante na infiltração marginal em esmalte e cemento, quando comparados aos seus correspondentes convencionais, o que pode ser atribuído às diferenças entre o coeficiente de expansão térmica da estrutura dentária e do material. Tem sido relatado que o coeficiente de expansão térmica dos ionômeros híbridos é menor que o das resinas compostas e mais alto que dos ionômeros convencionais. Todavia, é óbvia a melhoria no selamento marginal quando estes materiais são empregados, talvez pela propriedade de expansão higroscópica, compensando em parte a contração de polimerização. Segundo os autores, existem ainda outros fatores que podem ser coadjuvantes na redução ou inibição da microinfiltração: a capacidade de molhar adequadamente a superfície dentária em função de sua viscosidade; o tamanho das partículas de pó de vidro; o condicionamento da superfície; os diluentes adicionados ao líquido, assim como a proporção pó / líquido. Uma outra explicação seria a capacidade de adesão imediata destes materiais à dentina, uma vez que os cimento ionoméricos convencionais desenvolvem adesão com o tempo. 
MICHAILESCO et al. ${ }^{127}$ realizaram um estudo piloto, no ano de 1995, para registrar as alterações de temperatura durante a alimentação em 3 sítios da cavidade bucal. Para o registro, foram instalados "receptores térmicos" na base de uma restauração de amálgama, na superfície vestibular de uma restauração no primeiro molar inferior direito e dentro do canal radicular de um segundo molar inferior. Os registros foram realizados em pacientes distintos e as variações máximas registradas foram de $19,6^{\circ} \mathrm{C}$ na base da restauração, $27,1^{\circ} \mathrm{C}$ na superfície e $11,8^{\circ} \mathrm{C}$ no interior do canal radicular. Os autores defenderam uma padronização dos testes, afirmando que na maioria dos estudos as temperaturas empregadas e o número de ciclos térmicos são extremos e irreais, sugeriram ainda que os testes deveriam ser realizados usando temperaturas limítrofes de $17^{\circ} \mathrm{C}$ e $47^{\circ} \mathrm{C}$ com uma intermediária de $37^{\circ} \mathrm{C}$.

Em 1995 ZANATA et al. ${ }^{210}$ se propuseram, através de um trabalho laboratorial, a comparar a microinfiltração em cavidades restauradas pela técnica do "sanduíche", empregando diferentes combinações de cimentos ionoméricos / resina composta. Com esta finalidade, preparos cavitários de classe V com extensão gengival em cemento foram realizados em dentes caninos e pré-molares humanos, os quais foram restaurados representando cinco condições experimentais: A - Fuji II LC; B - Vitremer; C - GC Lining LC; D - Vitrebond / Silux Plus; E - Silux Plus ( adesivo dentinário / resina composta ). Antecedendo a realização dos testes, os dentes restaurados foram estocados por uma semana em água destilada à $37^{\circ} \mathrm{C}$. Receberam acabamento e polimento com discos Sof-Lex, tendo sido em seguida submetidos à termociclagem, correspondente a 500 ciclos, nas temperaturas de $4^{\circ} \mathrm{C}$ e $60^{\circ} \mathrm{C}$, com permanência de 1 minuto em cada banho. Antes, porém, de serem mergulhados em solução de fucsina básica a $2 \%$ para que fossem aguardadas 24 horas, a superfície dos dentes foi coberta por duas camadas de esmalte de unha, com exceção das 
margens da restauração. A análise da profundidade de penetração do corante foi realizada microscopicamente e o índice de infiltração atribuído através de escores. Os resultados não constataram diferenças significantes entre as condições testadas, nem com relação ao esmalte, nem mesmo às margens cervicais.

CAMPISTA; CHEVITARESE ${ }^{22}$ avaliaram “in vitro", no ano de 1995, a microinfiltração marginal de restaurações de classe $\mathrm{V}$, em pré-molares humanos extraídos, usando a associação Scothbond Multi-Uso/Z-100. Metade das amostras receberam acabamento imediato com lâminas de bisturi número 15 e discos Sof-Lex ( $3 \mathrm{M}$ ), a outra metade foi armazenada em água a $36+/-1^{\circ} \mathrm{C}$ por uma semana antes da realização do acabamento. Para a verificação da infiltração foi utilizado o nitrato de prata a $50 \%$. Pelos resultados obtidos, os autores concluíram que as amostras submetidas a acabamento após 7 dias exibiram menor microinfiltração e que esta foi maior nas interfaces compósito-cemento comparada à interface compósito-esmalte.

Com a preocupação em fornecer normas clínicas através das quais o profissional poderia lançar mão de condições adequadas para fotoativação dos materiais, CAUGHMAN; RUEGGEBERG; CURTIS ${ }^{28}$, em 1995, realizaram uma revisão de literatura com o intuito de estabelecer tais normas. Os autores recomendaram uma aquisição de unidades fotoativadoras de qualidade razoável e que as mesmas fossem avaliadas periodicamente para manter uma potência adequada. Os profissionais deveriam ficar atentos aos sinais de degradação do bulbo, do Trefletor e da fibra ótica das unidades. A degradação do bulbo e do refletor foi atribuída principalmente ao superaquecimento da unidade, o que pode ser minimizado caso a unidade disponha de uma ventoinha em boas condições. Um radiômetro dentário também deveria ser 
utilizado periodicamente para medir a intensidade de luz e, assim, predizer quando o bulbo deveria ser substituído. A intensidade mínima aceitável estaria entre 280 e $300 \mathrm{~mW} / \mathrm{cm}$. A resina composta também seria um fator importante para observação: partículas de carga entre 0.01 a 1 micron reduzem a penetração de luz devido ao fator dispersão, assim como matizes escuros também afetam negativamente a transmissão de luz. Cada incremento de resina composta não deveria exceder $2 \mathrm{~mm}$, e em casos de matiz escuro, $1 \mathrm{~mm}$. A distância da extremidade da ponta ativa da unidade não deveria ser superior a $6 \mathrm{~mm}$ da superfície da resina e um tempo de exposição de 60s seria recomendado.

DIETSCHI et al. ${ }^{48}$ avaliaram, no ano de 1995, a adaptação marginal e a microinfiltração em restaurações de classe II, diretas e indiretas, realizadas com Scothbond Multi-Uso/Z-100 ou com Optibond/Herculite. A influência da utilização de uma base de ionômero de vidro ( convencional ou fotopolimerizável ) também foi avaliada. Para o estudo, duas cavidades de classe II com margens cervicais em cemento foram preparadas em cada um dos molares humanos selecionados. As resinas e seus respectivos adesivos foram utilizados em duas técnicas distintas de restauração, direta pela técnica incremental e indireta. Estas restaurações foram subdivididas ainda em três grupos: sem forramento, forramento com um cimento de ionômero de vidro convencional (Ketac-Bond) ou com um fotopolimerizável (Vitrebond). Após as restaurações, as amostras foram armazenadas em solução fisiológica por 24 horas e então submetidas a 5000 ciclos térmicos a $5^{\circ} \mathrm{C}$ e $55^{\circ}$. Logo em seguida foram confeccionadas réplicas para exame ao microscópio eletrônico de varredura e os espécimes foram colocados em corante para avaliação da microinfiltração. Os resultados demonstraram superioridade para a técnica indireta de restauração. A associação Scothbond Multi-Uso/Z100 apresentou menos defeitos marginais e menor infiltração que Optibond/Herculite, 
especialmente nas restaurações diretas. O vedamento marginal e a adaptação dos inlays não foram beneficiados pela aplicação dos forramentos. Para as restaurações diretas, o desempenho da técnica sem forramento foi ligeiramente superior ao uso dos dois tipos de ionômeros.

Em 1995, YAP; LIM; NEO ${ }^{206}$, avaliaram a capacidade de selamento de três materiais restauradores, "um compômero", uma resina composta e um cimento de ionômero de vidro modificado por resina, em cavidades cervicais não cariosas. Os resultados demonstraram que não houve diferença estatisticamente significante na capacidade de selamento marginal em dentina entre os três materiais. Quando as margens localizavam-se em esmalte, as restaurações em resina composta apresentaram um menor grau de infiltração do que os demais materiais. De modo geral, a capacidade de selamento em dentina dos três materiais foi deficiente.

HOOD; BECCONSALL-JONES ${ }^{94}$ investigaram, neste mesmo ano, o efeito de um estresse mastigatório simulado na infiltração marginal em restaurações de resina composta e mistas (ionômero/resina). Para o experimento, 68 terceiros molares humanos extraídos receberam preparos padronizados de classe II ( 2 cavidades em cada dente ), os quais foram divididos em 4 grupos de acordo com a técnica de restauração empregada. Assim: o grupo 1 foi restaurado com a resina Z-100 (3M) sem agente de união; o grupo 2 foi restaurado com Scothbond Multi-Uso (3M) ; no grupo 3 utilizou-se o Vitremer (3M), preenchendo $25 \%$ da caixa proximal, associado ao Scothbond Multi-Uso (3M) e Z-100 (3M); no grupo 4 foram utilizados os mesmos produtos que no anterior, porém com Vitremer preenchendo $50 \%$ da caixa proximal. Uma das restaurações de cada dente foi submetida a 5000 ciclos de aplicações 
de uma carga de $11 \mathrm{~kg}$ à velocidade de 37 aplicações por minuto com o dente imerso em um corante. As amostras foram seccionadas e a infiltração avaliada na margem gengival. Os resultados demonstraram que: nenhuma das combinações eliminou a microinfiltração, mas as técnicas mistas reduziram-se substancialmente; a infiltração foi bem menor no grupo 3 comparado ao grupo 4, levando os autores a concluir que a utilização de uma grande massa do Vitremer pode dificultar sua polimerização completa ou acarretar em um alto grau de contração; a aplicação das cargas não provocou alteração significativa na infiltração marginal.

A infiltração marginal em restaurações classe II com margens em esmalte, em prémolares humanos extraídos foi avaliada por ROETERS; OPDAM ${ }^{170}$, em 1995. Todos os dentes foram restaurados com a resina Clearfil Ray Posterior ( Kuraray ) e divididos em grupos de acordo com os seguintes produtos empregados: grupo A - Photobond ( Kuraray ) e ácido fosfórico a 35\%; grupo B - técnica do "sanduíche" usando Vitrebond (3M) e o Photobond; grupo C - Scothbond Multi-Uso (3M) e ácido maleico a 10\%; grupo D - técnica do "sanduíche" usando Vitrebond e Scothbond Multi-Uso com ácido maleico a 10\%; grupo E - Scothbond Multi-Uso com ácido fosfórico a 35\%; grupo E - KB2000 ( Kuraray ) com "primer" auto-condicionante (self etching primer ). Após o acabamento das restaurações, os dentes foram submetidos a 500 ciclos térmicos e imersos em fucsina básica por 24 horas, em seguida foram seccionados e a microinfiltração foi avaliada pelo sistema de escores. Os autores concluíram que: o uso combinado do ácido fosfórico e um sistema adesivo dual ( Photobond - grupo A ) resultou em restaurações praticamente livres de microinfiltração; as cavidades condicionadas com ácido maleico ou com o primer auto-condicionante demonstraram maior infiltração; e a aplicação do cimento de ionômero de vidro aparentemente não influenciou na redução da microinfiltração. 
Considerando os princípios que regem e controlam as variáveis que geram os estresses desenvolvidos nas interfaces das restaurações de resina composta, CARVALHO et al. ${ }^{25}$, em 1996, através de uma revisão, descreveram os fatores que podem interferir na infiltração da resina adesiva, no interior da camada desmineralizada, e a influência desta infiltração na adesão entre o material restaurador e a estrutura dentária. A contração de polimerização sofrida pela resina poderá criar estresses que rompem a união junto às paredes cavitárias e essa competição entre o estresse mecânico sofrido pela polimerização e a união dos adesivos às paredes cavitárias consiste em uma das principais causas das falhas marginais e subsequente microinfiltração nestas restaurações. Os autores explicaram os efeitos da smear layer e a desidratação da superfície dentária desmineralizada. Relataram que o grau de estresse desenvolvido poderá ser controlado pela extensão e configuração da cavidade (fatorC), pelo emprego de bases, tamanho, forma e posição dos incrementos do material. Deve ser considerada ainda a natureza química ou fotopolimerizável das resinas compostas, considerando que o tipo de polimerização influencia a capacidade de escoamento do material. As resinas fotopolimerizáveis apresentam polimerização rápida ou imediata, o que permite menor escoamento, maior será o estresse gerado durante a contração de polimerização, resultantes de alguns estudos, cujas cavidades possuem configurações específicas, superaram a força adesiva da resina à dentina, esclarecendo talvez o alto e frequente índice de falhas e de formação de “gap" observados em vários estudos utilizando sistemas adesivos . Por outro lado, existem vários fenômenos e procedimentos relacionados à configuração, ao emprego de resinas quimicamente ativadas, baixo módulo linear e tempo de sorpção de água, os quais, caso bem entendidos e aplicados, contribuem para reduzir a contração de polimerização, oferecendo às restaurações melhor qualidade e longevidade. 
O efeito das técnicas de adesão seca e molhada na microinfiltração de restaurações de resina composta usando 3 diferentes sistemas adesivos foi estudado por SAUNDERS; SAUNDERS ${ }^{178}$ em 1996. Para avaliação foram utilizados 80 pré-molares humanos extraídos, os quais receberam preparos cavitários de classe $\mathrm{V}$ por vestibular e por lingual, com as margens cervicais em cemento/dentina. Os sistemas adesivos utilizados foram o Primer \& Bond ( Dentsply ), o Scothbond Multi-Uso Plus ( 3M ) e o Dentastic (Puldent Corp ). O Scothbond Multi-Uso Plus foi usado com ácido maleico a $10 \%$ e ácido fosfórico a 37\%. Os dentes foram divididos em 4 grupos de 10 e subdivididos de acordo com as técnicas aplicadas. Para a adesão "molhada", após o condicionamento as superfícies foram gentilmente jateadas com ar por 2 segundos e para a técnica "seca" as cavidades foram secadas por 15 segundos. Todos os dentes foram restaurados com a resina Z-100 ( 3M ) e as restaurações foram polidas imediatamente após a conclusão das mesmas. As amostras foram armazenadas por 2 semanas e então termocicladas por 1.500 vezes com banhos de 10 segundos em água às temperaturas de $5^{\circ} \mathrm{C}, 37^{\circ} \mathrm{C}, 55^{\circ} \mathrm{C}$ e $37^{\circ} \mathrm{C}$. Em seguida foram imersas em azul de metileno a $2 \%$ e seccionadas para avaliação por escores. Os resultados demonstraram que com o Primer \& Bond e o Dentastic a técnica molhada reduziu a infiltração na parede gengival. Não houve diferenças estatisticamente significativas entre as duas técnicas e os dois tipos de condicionadores utilizados com o Scothbond Multi-Uso Plus nas margens em cemento/dentina.

Ainda em 1996, FERRARI; DAVIDSON ${ }^{66}$ avaliaram “in vivo" a capacidade de selamento marginal de um cimento de ionômero de vidro modificado por resina e de um 
agente de união associado à resina composta, em cavidades de classe $\mathrm{V}$, preparadas em vinte dentes anteriores hígidos de dezessete pacientes adultos, apresentando grave envolvimento periodontal, indicados para exodontia. As cavidades foram confeccionadas na face vestibular, atingindo a junção esmalte-cemento, sob isolamento absoluto do campo operatório. Em um grupo de pacientes, utilizou-se o cimento ionomérico Fuji II LC, após o tratamento dentinário com o ácido poliacrílico. Os materiais de escolha para o segundo grupo foram: a resina composta Z-100 associada ao sistema adesivo dentinário Scothbond MP. Imediatamente após a polimerização do material, procedeu-se ao acabamento e polimento para todas as restaurações, utilizando-se discos Sof-Lex. Decorrido um período clínico de 75-90 dias, os dentes foram extraídos e estocados em solução de cloramina a 1\%, a temperatura ambiente por sete dias e em seguida, imersos em solução de azul de metileno por 24 horas. Os espécimes foram então seccionados inciso-apicalmente, inspecionados em um estereomicroscópio com aumento de 20 vezes e a profundidade de penetração do corante foi registrada, através da atribuição de escores. Apesar de não mais que 30\% das restaurações de cada grupo terem exibido microinfiltração, nenhum dos sistemas restauradores foi capaz de selar efetivamente as margens das restaurações e prevenir a penetração da solução corante. A análise estatística dos resultados não constatou existência de diferença significante entre os dois grupos estudados.

Em 1996, TRUSHOWSKY; GWINNET ${ }^{193}$ estudaram “in vitro” o comportamento dos cimentos de ionômero de vidro modificados por resina, utilizados em restaurações de classe $\mathrm{V}$ com o término cervical em cemento, associando o uso destes materiais à redução de microinfiltração marginal. As cavidades foram preparadas nas faces vestibular e lingual de trinta e cinco molares recém-extraídos e quatro cimentos ionoméricos foram pesquisados, 
variando as condições experimentais: Grupo 1 (grupo controle) - Scothbond MP / resina composta Z-100; Grupo 2 - Ionômero Fuji Lining (na parede axial) / Scothbond MP / Z-100; Grupo 3 - ácido poliacrílico 10\% / Fuji II LC / Scothbond MP / Z-100; Grupo 4 - Vitrebond / Scothbond MP / Z-100; Grupo 5 - Vitremer / Scothbond MP / Z-100. Para todos os grupos até então mencionados, a resina composta foi inserida através da técnica incremental. Para os demais grupos, 6 e 7, as cavidades foram totalmente restauradas com os cimentos ionoméricos Fuji II LC e Vitremer respectivamente. Imediatamente após a polimerização, as restaurações foram polidas com discos Sof-Lex, sendo posteriormente submetidas à termociclagem a $5^{\circ} \mathrm{C} \mathrm{e}$ $55^{\circ} \mathrm{C}$. As superfícies externas dos dentes eram seladas com esmalte de unha até a $1 \mathrm{~mm}$ aquém da periferia da restauração, sendo os mesmos armazenados em solução de nitrato de prata $50 \%$ e posteriormente seccionados para avaliação. O grau da microinfiltração em cada corte foi determinado pela penetração dos íons prata através das interfaces esmalte / material restaurador na parede oclusal e cemento / material restaurador na parede gengival. Os resultados evidenciaram um índice moderado de infiltração apenas em 1 espécime do grupo 6 (Fuji II LC) em esmalte, apresentando 69 dos 70 espécimes isentos de infiltração nesta região. Com relação à margem gengival, 1 a 2 espécimes dos grupos 1 (Z-100), 4 ( Vitrebond / Z100), 6 (Fuji II LC) e 7 (Vitremer) apresentaram uma suave penetração da solução e aproximadamente 64 dos 70 espécimes demonstraram isenção de microinfiltração. Os resultados estatísticos não exibiram valores significantes entre as condições experimentais testadas. Neste estudo, os autores relataram como sendo de relevância clínica o fato da base de cimento de ionômero de vidro modificado por resina não ter interferido significantemente na habilidade das restaurações em resistir à microinfiltração. 
A influência do uso de resinas de baixas viscosidade na redução da microinfiltração de restaurações adesivas foi avaliada por SWIFT JUNIOR et al. ${ }^{188}$, em 1996. Neste estudo, cavidades de classe $\mathrm{V}$, com margens cervicais em cemento/dentina, foram preparadas nas faces vestibulares e linguais de 132 molares humanos extraídos. Um dos 5 sistemas adesivos (All-Bond 2, Clearfil Liner Bond 2, Optibon, Primer \& Bond e Scothbond Multi-Uso ) foi utilizado em uma das cavidades de cada grupo, seguindo as instruções do fabricante e na outra cavidade o sistema selecionado foi associado a uma resina de baixa viscosidade ( Optibond FL Adhesive ou Protect Liner F ).Todos os dentes foram restaurados com Z-100 e as restaurações foram submetidas a acabamento 10 minutos após a conclusão. Os espécimes foram armazenados em água a $37^{\circ} \mathrm{C}$ por 24 horas e então termociclados por 800 vezes entre $5^{\circ} \mathrm{C}$ e $55^{\circ} \mathrm{C}$ com banhos de 30 segundos. Em seguida, foram imersos em solução de nitrato de prata a $50 \%$ e seccionados para avaliação por escores . Dos sistemas adesivos testados, o Optibond e o Clearfil Liner Bond 2 foram mais efetivos na redução da microinfiltração nas margens cervicais. O uso da resina de baixa viscosidade como All-Bond 2 e Prime \& Bond exerceu pequeno efeito no padrão de infiltração, mas o uso do Protect Liner F reduziu significativamente a microinfiltração do Scotchbond Multi-Uso.

SHORTALL; HARRINGTON ${ }^{179}$, em 1996, propuseram-se a revisar o desenvolvimento das unidades fotoativadoras e do perfil de cada um dos componentes destas unidades. Os autores concluíram que uma unidade fotoativadora adequada deveria apresentar uma saída de luz estável ao redor de $300 \mathrm{~mW} / \mathrm{cm}^{2}$ dentro do comprimento de onda desejado, a ponta ativada deveria ser autoclavável, a unidade não deveria apresentar um aquecimento excessivo, o ventilador deveria ser silencioso, os dispositivos de regulagem dos tempos de 
fotoativação deveriam propiciar repetição imediata, com sons audíveis e deveria ser passível de interrupção.

O vedamento marginal de restaurações de resina composta classe II em função da localização das margens cervicais foi avaliado por SCHUCKAR; GEURTSEN ${ }^{176}$, em 1996. Para o estudo foram utilizados 60 molares humanos extraídos, nos quais foram realizados preparos de classe II MOD. Os dentes foram divididos em grupos de acordo com a localização das margens cervicais, assim: no grupo I a parede gengival foi localizada $1 \mathrm{~mm}$ acima da junção amelo-cementária; o grupo II 5 mm acima desta junção; o grupo III a e b na junção amelo-cementária; o grupo IV a e b 5 mm abaixo da junção. Cada grupo compreendeu 10 amostras. Todas as cavidades foram forradas com um cimento de ionômero de vidro e restauradas com a resina Tetric. Nos grupos IIIb e IVb o adesivo Syntac foi utilizado. Metade das amostras de cada grupo foi termociclada ( 2000 ciclos entre $5^{\circ} \mathrm{C}$ e $55^{\circ} \mathrm{C}$ ) e a outra metade serviu como controle. $\mathrm{O}$ vedamento marginal foi verificado pela penetração de corante. Os resultados demonstraram que a termociclagem deteriorou a adaptação marginal apenas nos grupos II, IVa e IVb. Os autores concluíram que a aplicação de um sistema adesivo deve melhorar o vedamento marginal em restaurações de resina localizadas próximas ao limite amelo-cementário.

GONÇALVES $^{75}$, em 1996, avaliou “in vitro” o efeito dos estresses mecânico e térmico e do forramento com ionômero de vidro fotopolimerizável (Vitrebond - 3M) na microinfiltração marginal de restaurações de classe II feitas com resina composta, usando dois sistemas adesivos (Scotchbond Multi-uso - Z-100 e Optibond - Herculite XRV). Cavidades M.O.D. padronizadas foram realizadas em 60 pré-molares com as margens cervicais 
localizadas a $1 \mathrm{~mm}$ acima do limite amelo-cementário; a parede gengival de uma das caixas proximais recebeu uma cobertura com Vitrebond e os dentes foram divididos em dois grupos, de acordo com o material utilizado. Depois de restaurados, os espécimes foram armazenados em solução fisiológica por 24 horas e divididos em três grupos: grupo 1 - 10 amostras de cada material foram submetidas a estresse mecânico com 10 ciclos diários de aplicação de cargas de $1 \mathrm{~kg}$ e $17 \mathrm{~kg}$ durante 7 dias; grupo 2 - 10 espécimes de cada material foram termociclados (500 ciclos, 5-55 $\mathrm{C}$, 15 segundos); no grupo 3 - as amostras não foram submetidas a nenhum tipo de estresse, servindo como controle. Os dentes foram imersos em solução corante (fucsina básica a 0,5\%), lavados e seccionados. Os resultados revelaram que, independentemente do estresse aplicado, nenhum sistema foi capaz de bloquear totalmente a infiltração marginal. Com base nos resultados, o autor concluiu que: os dentes restaurados com o conjunto Optibond - Herculite XRV exibiram significativamente menos infiltração que os dentes restaurados com o conjunto Scotchbond Multi-uso - Z-100; as amostras submetidas ao estresse térmico não apresentaram aumento nos níveis de infiltração quando comparadas às do grupo controle, para ambos os sistemas avaliados, e o uso do ionômero diminuiu significantemente a infiltração nas amostras do grupo em que o conjunto Optibond - Herculite XRV foi submetido ao estresse mecânico.

O estudo desenvolvido por SJODIN; UUSITALO; DIJKEN ${ }^{184}$, em 1996, teve por finalidade estudar a microinfiltração marginal em cavidades de classe V e II restauradas com cimentos ionoméricos convencionais e modificados por resina e com resinas poliácido modificadas, além da resina composta. Para as restaurações de classes $\mathrm{V}$, as cavidades foram preparadas nas faces vestibular e lingual de 50 dentes pré-molares, sendo uma com término cervical em cemento e a seguinte em esmalte. Os materiais, Fuji II LC, Vitremer, Dyract, 
Chemfil II e Herculite, manipulados de acordo com as instruções de seus fabricantes, foram utilizados nas restaurações de cada 10 dentes e, após uma semana de armazenamento em água, foram acabados e polidos . Na segunda parte do estudo, 40 das 50 cavidades de classe II MOD foram preparadas, e restauradas pela técnica do "sanduíche", utilizando, em associação com a resina composta Herculite, o Fuji II LC, o Vitremer, o Dyract e o Chemfil II (controle); o quinto grupo foi restaurado unicamente com a resina composta Herculite. Em metade dos espécimes restaurados pela técnica do "sanduíche", o cimento de ionômero de vidro foi protegido com um verniz cavitário, para evitar sua união com a resina, sendo nos demais esta mesma superfície condicionada, para permitir a união dos dois materiais através de um agente adesivo. Dando continuidade, todos os dentes foram termociclados, constituindo 180 ciclos nas temperaturas de $5^{\circ} \mathrm{C}, 37^{\circ} \mathrm{C}$ e $55^{\circ} \mathrm{C}$, com banhos de 10 segundos em cada temperatura. Após adequadamente vedados, os dentes foram estocados por 24 horas em solução de azul de metileno a $5 \%$ e posteriormente seccionados para avalição. Os cortes foram microscopicamente examinados quanto ao padrão de infiltração. Os resultados demonstraram para as restaurações de classe V a superioridade dos materiais Dyract e Fuji II LC, tanto em esmalte quanto em dentina, sendo em esmalte semelhantes à "performance" do Vitremer. Para o grupo II, com a técnica de restauração sem aplicação do verniz, com margens em esmalte, o melhor resultado foi conferido ao Dyract, seguido pelo Fuji II LC e Vitremer. Em dentina, o padrão de infiltração para estes mesmos espécimes foi muito alto, destacando-se como os melhores resultados o Dyract e o Fuji II LC, sem o contudo haver diferença estatística entre estes e os demais materiais testados. O uso do verniz não modificou o padrão de infiltração nas margens de esmalte; já em dentina houve grande variação quando comparados com as amostras sem verniz. Os resultados deste estudo sugerem que a microinfiltração marginal inicial dos materiais modificados por resina e por ionômero é maior do que a obtida pelo 
cimento de ionômero de vidro convencional testado, embora nenhuma das técnicas tenha resistido à microinfiltração tanto em esmalte quanto em cemento.

O objetivo do trabalho realizado em 1996, por SÁBIO ${ }^{175}$, foi avaliar a infiltração marginal em relação à adaptação de resinas compostas quimicamente ativadas e fotoativadas às paredes do preparo cavitário. Para tanto, cavidades mesial e distal estendidas $2 \mathrm{~mm}$ aquém da junção cemento-esmalte foram preparadas em 20 dentes molares humanos extraídos. Assim, as quarenta cavidades foram distribuídas em 4 grupos experimentais de 10 elementos cada, os quais foram restaurados com resinas compostas foto e quimicamente ativadas, com e sem o emprego de um agente de união. Concluídas as restaurações, os dentes foram protegidos por duas camadas de esmalte de unha e imersos em solução de azul de metileno a $2 \%$, permanecendo 20 horas a $37^{\circ} \mathrm{C}$. Os espécimes seccionados foram avaliados através de microscopia óptica com aumento de $40 \mathrm{X}$ e os índices de infiltração marginal foram estabelecidos segundo o critério de escores. Os resultados obtidos foram submetidos á análise estatística, permitindo chegar às seguintes conclusões: o grau de infiltração foi total para os dois tipos de resinas compostas; a resina composta quimicamente ativada, quando utilizada com o respectivo agente de união, apresentou menor grau de infiltração marginal tanto nas margens de esmalte oclusal quanto nas cervicais; os grupos restaurados com a resina composta fotopolimerizável, com e sem o emprego do agente de união, não apresentaram diferença estatisticamente significante, independente da localização da margem. Não obstante o melhor comportamento da resina composta quimicamente ativada, observou-se que nenhum sistema restaurador conseguiu impedir totalmente a infiltração do corante nas margens das restaurações. 
ALANI; TOH $^{1}$ em 1997, discutiram os principais métodos para detecção da microinfiltração ao redor das restaurações, como infiltração de corantes orgânicos, agentes traçadores químicos, traçadores radioativos, utilização de bactérias, uso de ar comprimido, produção de cáries artificias, análises em microscópio eletrônico de varredura, análise através de ativação de nêutrons e condutividade elétrica. Também foi discutida a influência da termociclagem nos resultados da avaliação da microinfiltração. Observou-se grande variedade no que se refere às temperaturas utilizadas nos ciclos, a duração de cada banho e no número de ciclos, verificando-se que não existe um consenso a respeito destes fatores devido à deversidade de trabalhos com resultados contraditórios. A influência da ciclagem mecânica também foi sugerida como mais um fator de importância ao simular as condições intrabucais. Os autores concluíram que não há nenhum método ideal para detecção de microinfiltração. Sugerem a utilização de agentes traçadores como um método com um grau de confiabilidade razoável, considerando-se suas desvantagens.

Em 1997, DAVIDSON; FEILZER ${ }^{44}$, em revisão da literatura, discutiram os métodos de determinação da contração de polimerização e do estresse gerado por esta contração, juntamente com os efeitos clínicos desta contração dos materiais adesivos. A contração estaria diretamente relacionada com as próprias características e composição do material, consistindo num fenômeno intrínseco ao mesmo. O estresse da contração ocorreria quando a contração fosse obstruída e o material seria rígido o bastante para resistir ao escoamento plástico, o qual compensaria o volume original. O alívio deste estresse seria dependente da configuração cavitária e da modulação do início da reação de polimerização. Mas pensou-se que a contração pudesse ser, em parte, compensada pela expansão higroscópica da resina, porém este consistiria num complexo processo. Os autores concluíram que, apesar dos avanços dos 
materiais, o profissional deveria conviver com o problema da contração de polimerização e seu estresse, tentando entender todo o processo e buscar técnicas para minimizar seu efeito.

No encontro da IADR, de 1997, FRANCI; SANTOS ${ }^{69}$ apresentaram um trabalho de pesquisa relacionado à microinfiltração em restaurações estéticas de classe II MOD, combinando amálgama e resina composta. As cavidades foram preparadas apresentando uma caixa com o término cervical em cemento e a outra ao nível de esmalte. Em metade dos espécimes, as caixas proximais foram restauradas com amálgama (Dispersalloy), até a altura do ângulo áxiopulpar, com e sem a aplicação de um sistema adesivo (All-Bond 2 ou Optibond) e, o restante da cavidade, assim como toda a cavidade para os demais espécimes foram preenchidas alternadamente com as resinas compostas Z-100, Charisma e Heliomar. Durante a termociclagem das restaurações, houve incidências de cargas oclusais e posterior imersão em solução corante de azul de metileno 0,5\%. Após seccionados, os espécimes foram microscopicamente avaliados e estisticamente analisados. Os resultados indicaram a ocorrência de microinfiltração nas interfaces tanto de esmalte quanto de cemento, apresentando-se superior para a última: Os autores, observando a significante redução da microinfiltração pelo emprego do amálgama, indicaram a restauração combinada amálgama / adesivo / resina composta para restaurar esteticamente cavidades convencionais tipo classe II.

A Dissertação apresentada à FOB-USP, em 1997, por PIN ${ }^{158}$, partiu do princípio que a eliminação da infiltração marginal ao redor de restaurações dentárias constitui um sério desafio para a Odontologia. Na tentativa de minimizar este problema, a autora avaliou "in vitro" a infiltração marginal decorrente do emprego de um cimento ionomérico convencional (Fuji IX), dois cimentos ionoméricos modificados por resina (Fuji II LC - Vitremer ) e de 
uma resina composta poliácido modificada (Dyract). Cavidades de classe II tipo slot vertical, estendendo-se $1 \mathrm{~mm}$ além da junção cemento-esmalte, foram preparadas nas faces mesial e distal de 40 pré-molares humanos livres de cáries, extraídos por indicação ortodôntica. Após restaurados com os materiais acima citados, os dentes eram adequadamente selados, submetidos à ciclagem térmica nas temperaturas de $5^{\circ} \mathrm{C}$ e $55^{\circ} \mathrm{C}$, com o tempo de imersão de 15 segundos durante 500 ciclos e, em seguida, armazenados em solução de fucsina básica a $0,5 \%$ a $37^{\circ} \mathrm{C}$ por 24 horas, antes de serem seccionados para avalição microscópica. Verificouse a penetração do corante ao longo da parede gengival, na interface dente / restauração para cada face dos cortes, registrando-se a medida linear em micrômetros. Pela análise dos resultados, nenhum dos materiais testados foi capaz de impedir totalmente a infiltração marginal. As restaurações de Vitremer apresentam um índice de penetração do corante significantemente menor, comparado aos demais materiais, e o uso do cimento ionomérico convencional ocasionou os piores resultados, os quais foram estatiscamente significantes em relação a todos os outros materiais. Os valores intermediários foram correspondentes ao Fuji II LC e o Dyract, demonstrando os mesmos um padrão semelhante de infiltração marginal.

Em 1998, FERRACANE; MITCHEM; $\mathrm{ADEY}^{64}$ avaliaram a liberação de flúor e a microinfiltração "in vitro" de um dos três novos sistemas adesivos contendo flúor e demonstraram evidência da liberação de flúor destes sistemas e sua penetração na dentina ao redor de restaurações de cavidades de classe V. Foram utilizados o sistema restaurador FB/Litefil, o qual consistia num sistema de três componentes, e o sistema Scothbond MP/Z100, de acordo com as instruções dos fabricantes. Para a verificação de liberação de flúor, os espécimes cilíndricos em resina foram armazenados em água deionizada a 27 graus Celcius por 1, 7, 14, 21, 35, 77 e 112 dias; todas as análises foram feitas com um eletrodo 
específico para a medição. Para os testes de microinfiltração, foram confeccionadas cavidades de classe V nas superfícies vestibular e lingual de terceiros molares humanos extraídos, com metade da cavidade acima a JCE. Os dentes foram armazenados em água deionizada a 37 graus Celcius por 1 mês e não foi realizada a termociclagem. Então, os dentes foram imersos em solução $3 \mathrm{M}$ de nitrato de prata por $24 \mathrm{~h}$, lavados e colocados em solução reveladora sob luz fluorescente por $24 \mathrm{~h}$. O acúmulo de flúor na água, provindo do sistema adesivo FB aumentou continuamente ao longo do tempo, havendo um declínio na taxa de liberação do elemento; a taxa inicial de liberação foi de $0.096 \mathrm{ppm} / \mathrm{dia}$, atingindo taxas de $0.021 \mathrm{ppm} / \mathrm{dia}$ nos últimos dois períodos de medição. Os resultados da análise de microinfiltração demonstraram que não houve diferença estatisticamente significante entre os dois sistemas adesivos nas margens de esmalte e cemento, sendo que o grau de infiltração foi mais alto na margem gengival. A concentração de flúor foi mais evidente na base da camada híbrida e na dentina subjacente a ela.

VERSLUIS; TANTIBIROJN; DOUGLAS ${ }^{196}$, em 1998, analisaram o vetor de contração para as resinas compostas quimicamente ativadas e fotoativadas e, em particular, examinaram a afirmação de que as resinas compostas contraíram em direção à luz. Para tanto, foi utilizada a análise do elemento finito para estudar a direção de polimerização das resinas. Segundo os autores, o processo de polimerização pode ser caracterizado pelas fases pré e pósgel. Os estresses residuais surgem após esta geleificação. Nas resinas fotoativadas, o ponte gel varia através do material de acordo com a intensidade de 1 . Neste estudo também foram determinados o grau de conversão das resinas e as propriedades de contração tempodependentes. A análise demonstrou que a direção de contração não foi significantemente afetada pelo direcionamento da aplicação da luz, mas foi determinada pelas superfícies da 
restauração aderidas ao dente e pelas superfícies livres. Consequentemente, diferenças entre os padrões de contração das resinas auto e fotoativadas foram semelhantes. Concluiu-se que as resinas compostas não contraíram em direção à luz, mas esta direção foi predominantemente determinada pela forma cavitária e pela qualidade adesiva. Dever-se-ia buscar propriedades marginais adequadas para otimizar outros fatores, como o processo de polimerização, o procedimento de fotoativação e a qualidade adesiva . A direção dos vetores de contração em relação à posição da luz não parece ser um critério apropriado para otimizar a qualidade marginal das restaurações.

MIYAZAKI et al. ${ }^{129}$, em 1998, propuseram-se a avaliar a influência da ciclagem térmica na resistência adesiva à dentina de sistemas adesivos que utilizavam dois passos operatórios. Os sistemas utilizados foram 3 sistemas adesivos com "primers" autocondicionantes - Fluoro Bond/Lite-Fil II A, Liner Bond II /Clearfil Ap-X e Mac Bond II /Palfique Estelite; e 4 sistemas monocomponentes - One-Step /Aelitefil, OptiBond Solo/ Prodigy, Prime \& Bond 2.0 / Spectrum e Single Bond / Z100. Todos os sistemas foram utilizados de acordo com as instruções do fabricante e foi empregada a unidade fotoativadora Optilux 401 a uma intensidade de $600 \mathrm{~mW} / \mathrm{cm}$. Para os testes de resistência adesiva com cisalhamento foram utilizados dentes bovinos sobre os quais foram preparados os espécimes cilíndricos em resina composta. Após o preparo dos espécimes, cada grupo foi subdividido em 4 com tratamentos distintos: 1 - Os dentes ficaram imersos em água a 37 graus Celcius por 24 horas, sem termociclagem; 2 - Imersão em água por 24 horas, em seguida os dentes sofreram termociclagem em banhos a 5 graus Celcius e 60 graus Celcius por 3000 ciclos; 3 - Imersão em água a 37 graus Celcius por 24 horas e termociclagem em banhos a 5 graus Celcius por 1000 ciclos; 4 - Imersão em água a 37 graus Celcius em banhos a 5 graus e 60 graus Celcius 
por 3000 ciclos. Cada banho teve a duração de 30 s e o tempo de transferência entre um e outro foi de 5 s. Após estes procedimentos, os espécimes foram submetidos ao teste de cisalhamento e, então, foram observados em microscópio eletrônico de varredura para análise do modo de fratura. De modo geral, a média de resistência de todos os sistemas adesivos decaíram com o número de ciclos. Para os sistemas adesivos monocomponentes, a média de resistência adesiva à dentina decaiu significantemente com o tratamento térmico utilizando 30000 ciclos, enquanto que não houve diferença estatisticamente entre os sistemas adesivos auto-condicionantes. Observando-se o modo de fratura, houve uma tendência à diferença entre os grupos termociclados. Nos grupos termociclados por 3000 ciclos, foram observadas pequenas rupturas abaixo da zona de interdifusão resina-dentina nos sistemas adesivos monocomponentes, mas estas não foram observadas nos sistemas adesivos autocondicionantes.

Aspectos sobre o alívio do estresse, principalmente dos métodos para controle deste, quando causado pela contração de polimerização, foram abordados por DAVIDSON ${ }^{40}$, em 1998. O controle de estresse pelo fluxo, segundo o autor, poderia ser feito pela escolha adequada dos materiais, pelo manuseio criativo e pela manutenção de um fator-C o mais baixo possível. Esse fluxo é limitado e ocorre principalmente na fase pré-gel; já na fase pósgel, a capacidade de fluxo diminui e a dureza continua a aumentar até que é alcançado um platô e então, quanto mais o processo demorar, mais a restauração conseguirá se adaptar à contração. O autor abordou também outras formas de controle do estresse, como: pela elasticidade adicional, onde a utilização de materiais de baixo módulo (como forradores) reduzem o estresse durante a contração do material restaurador; compensação por mudanças de volume, onde a presença de porosidades (criadas durante a espatulação das resinas 
quimicamente ativadas) no material pode contribuir para o alívio de estresse; controle pela variação da energia irradiada. Diminuir a velocidade de conversão através da variação da energia de irradiação é outro mecanismo interessante para reduzir o estresse primário, dessa forma promove-se a união, mantendo a integridade marginal, desde que isso não influencie as propriedades mecânicas finais. Finalizando, o autor comenta que essas táticas são métodos efetivos no controle dos estresses gerados durante a contração do material restaurador.

RUSSEL; MAZER ${ }^{173}$, em 1998, avaliaram a infiltração marginal quando uma resina composta de baixo módulo de elasticidade foi utilizada como base, em molares com cavidades de classe II M.O. ou O.D., restauradas com resina composta Z-100. Os grupos foram divididos segundo a técnica restauradora: grupo A - sistema adesivo, resina de baixo módulo e resina Z-100; grupo B - sistema adesivo e resina Z-100. Depois de restaurados, os dentes foram sujeitos à ciclagem mecânica (70N por 100.000 ciclos) e à ciclagem térmica (250 ciclos entre $5^{\circ}-55^{\circ} \mathrm{C}$, em solução de fucsina básica a $0,5 \%$ ). Os resultados mostraram uma diferença significante na infiltração ao longo das paredes da caixa oclusal, mas essa diferença não foi observada na parede gengival da caixa proximal. Os autores concluíram então que a resina de baixo módulo não influenciou na infiltração da parede gengival, porém a infiltração nas paredes laterais da caixa oclusal exibiram menor infiltração do corante.

No mesmo ano GORACCI ${ }^{76}$ discutiu trabalhos a respeito da qualidade da camada híbrida, abordando alguns pontos como: a necessidade de uma dentina úmida; a importância de um ácido em concentração adequada e um tempo específico de aplicação; uma polimerização que permita um bom escoamento da resina composta nas paredes da cavidade, com perfeita saturação das correntes resinosas. $\mathrm{O}$ autor atenta também para a influência das 
variações existentes nos substratos dentais, principalmente quando estes, neste caso a dentina, são acometidos pelo processo carioso, o qual se ativo por tempo suficiente pode provocar uma esclerose dos tecidos dentinários subjacentes e, assim, não existindo os túbulos para penetração da resina líquida, todo processo de adesão dependerá somente da camada híbrida. Essas diferenças nos substratos dentinários (tubulares com poucos ou muitos túbulos ou esclerosados sem túbulos), podem afetar consideravelmente o tipo de união, tornando necessária a escolha correta de um dos vários sistemas adesivos (mais ou menos fluidos, densos ou até mesmo com carga) disponíveis até o momento. Isto, juntamente com a adoção das técnicas descritas previamente, são táticas valiosas no campo da dentística estética conservadora.

Em 1999, LOESCHE $^{115}$ investigou as razões para os bons resultados alcançados com técnica de polimerização em 3 incrementos, preconizada por Lutz em 1986, procurando saber se poderiam ser atribuídos somente aos efeitos do direcionamento da polimerização ou à redução da intensidade de luz. Foram confeccionadas cavidades de classe II em molares humanos extraídos, montados de forma a reproduzir a situação clínica de fotoativação. Para avaliação da técnica de polimerização, foram adaptadas matrizes de poliéster com cunhas reflexivas e matrizes metálicas com cunhas de madeira. Foram inseridos fotodetectores para medir e regular as intensidades de luz, as quais foram utilizadas em intensidades baixas ( 150 $\mathrm{Mw} / \mathrm{cm}^{2}$ ) e altas ( $450 \mathrm{~mW} / \mathrm{cm}^{2}$ ). A resina composta foi inserida segundo a técnica de Lutz e fotoativada de duas formas: por oclusal e seguindo a técnica preconizada pelo mesmo autor. Os dentes forma imersos em água à temperatura ambiente durante 21 dias e, então, foram submetidos à termociclagem ( $2000 \mathrm{x}, 5^{\circ} \mathrm{C}$ a $55^{\circ} \mathrm{C}$ ). Também foi avaliada a adaptação marginal das restaurações através da análise dos espécimes em MEV. Nas margens oclusais e 
verticais, a adaptação foi considerada satisfatória e não houve diferença estatisticamente significante entre os grupos. Os resultados nas margens cervicais demonstraram a influência de uma contração de polimerização rápida e de grande magnitude com altas intensidades de luz. Houve um aumento de defeitos marginais após a termociclagem para os dois grupos fotoativados com uma intensidade baixa de luz, justificados pelo autor como função da polimerização pós-irradiação. O autor conclui que os bons resultados da técnica incremental de Lutz não deveriam ser atribuídos ao efeito da fotoativação guiada, mas à fotoativação com baixas intensidades de luz.

O propósito do estudado desenvolvido em 1999 por DIETRICH et al. ${ }^{47}$, foi avaliar “in vitro" a adaptação marginal em cavidades MOD extensas, com margens cervicais em dentina, restauradas pela técnica do "sanduíche", utilizando cimentos de ionômeros de vidro modificados por resina e compômeros, comparando-os às restaurações de resina composta associada ou não à base de cimento ionomérico. Com tal finalidade, as cavidades foram confeccionadas em 120 dentes molares humanos extraídos, distribuídos em 15 grupos experimentais de 8 elementos cada, restaurados através de três diferentes técnicas: 1 - técnica do "sanduíche": Vitremer / Z-100, Compoglass / Tetric, Dyract / Prisma TPH, resina experimental ( De Trey ) / Prisma TPH , Photac-Fill / Prisma TPH, Vivaglass Liner / Tetric, Fuji II LC / Tetric; 2 - Restauração de resina composta - Z-100, Prisma TPH, Pertac Hybrib, Tetric; 3 - Base de ionômero de vidro associada à resina composta - Vitrebond / Z-100. As restaurações foram realizadas pela técnica incremental, utilizando-se matrizes transparentes e cunhas refletivas. Para a associação Vitremer / Z-100, avaliou-se ainda a influência de diferentes técnicas de polimerização, polimerização oclusal ou polimerização através das paredes cavitárias por meio da qual reduz-se a intensidade inicial de luz, variando também as 
matrizes (transparentes e metálica) utilizadas durante os procedimentos restauradores. Durante o período de 21 dias, os espécimes permaneceram armazenados em água destilada. As restaurações foram então polidas e submetidas à termociclagem correspondentes a 500 ciclos nas temperaturas de $5^{\circ} \mathrm{C}$ e $55^{\circ} \mathrm{C}$. Posteriormente os espécimes foram moldados para a avaliação das condições marginais. Raras fraturas foram observadas nas margens verticais em esmalte não tendo sido a adaptação marginal nessa região atribuída à técnica de restauração. Com relação às margens em dentina, o resultado da adaptação foi significantemente melhor para as restaurações "sanduíche" em comparação às demais. O melhor desempenho foi correspondente à associação Vitremer / Z-100, embora não tenha diferenciado do ponto de vista estatístico em relação à associação compômeros / resinas compostas. A combinação Vitremer / Z-100 associada ao emprego da matriz metálica e técnica oclusal de polimerização foi a condição experimental que se sobressaiu com a maior porcentagem de margens excelentes. Os autores concluíram que tanto os cimentos ionoméricos modificados por resina quanto os compômeros, favorecem a qualidade marginal das restaurações quando empregados através da técnica do "sanduíche", sendo imprescidível o desenvolvimento de novas pesquisas no sentido de determinar com precisão qual a melhor combinação de materiais para esse tipo de restauração.

HASEGAWA et al. ${ }^{88}$, em 1999, avaliaram a eficácia do sistema adesivo Single Bond através da medição das fendas oriundas da contração de polimerização. Foram preparadas cavidades cilíndricas em superfícies de dentina nas faces proximais de molares humanos extraídos. As cavidades foram condicionadas por 15 s, lavadas por 10 s e foi retirado o excesso de umidade. Então, foram restauradas com Silux Plus ou Z100, mediante aplicação de uma camada do adesivo, como preconiza o fabricante, ou em duas camadas. Também foi 
confeccionado um grupo controle, cujas cavidades foram condicionadas com EDTA $0.5 \mathrm{M}$ por 60s, lavadas por 10s, secas, aplicado o "primer" e o adesivo Clearfil /Silux Plus foram significantemente menores do que Single Bond / Silux Plus com uma camada de adesivo; e as fendas de Single Bond / Z100 com duas camadas de adesivo foram menores do que Single Bond / Z100 com uma camada e Clearfil / Z100. O autor conclui que , para prevenir a formação de fendas de Silux Plus e Z100, em cavidades dentinárias cilíndricas, a aplicação do adesivo Single Bond em duas camadas foi significantemente eficaz.

Avaliando a extensão da infiltração em restaurações de classe II com resina composta (Z-100), MAZER; RUSSELL ${ }^{124}$, em 1999, utilizaram 48 molares humanos extraídos (12 por grupo). Os grupos foram divididos de acordo com os materiais empregados: grupo 1 - adesivo + Z-100 (controle); grupo 2 - adesivo + AeliteFlo + Z-100; grupo 3 - adesivo + Florestone + Z-100; grupo 4 - adesivo + Tetric Flow + Z-100. A resina foi inserida incrementalmente e depois realizado o acabamento com brocas de 12 lâminas. Os dentes foram submetidos ao carregamento oclusal $(100.000$ ciclos, $70 \mathrm{~N})$, à termociclagem $(250$ ciclos, 5-55 $)$ e depois seccionados no sentido M-D e V-L. Os resultados mostraram uma diferença significante no grau de infiltração ao longo da caixa oclusal $(\mathrm{p}=.001)$ entre o grupo controle e os outros grupos, porém nenhuma diferença significante $(\mathrm{p}=.82)$ foi encontrada na parede gengival entre os grupos. Os autores concluíram que as resinas de baixo módulo de elasticidade testadas reduziram a infiltração ao longo das paredes da caixa oclusal, porém na caixa proximal não houve diferença de uso ou não desses materiais na prevenção da microinfiltração. 
Em 1999, LALSINGH et al ${ }^{107}$, compararam o grau de microinfiltração em cavidades de classe $\mathrm{V}$ em resina composta, a qual foi fotoativada com 4 diferentes unidades fotoativadoras. As cavidades de classe V ( 4 x 2x 1.5mm) foram preparadas em molares e prémolares humanos extraídos, com a margem gengival acima de JCE. Todos os dentes foram restaurados com o sistema Single Bond/Z100 de acordo com as instruções do fabricante. Os dentes foram divididos em 4 grupos de 2 dentes cada: G1 - controle, Optilux 500 por 40s; G2 - Elipar Highlight, por 10s com baixa intensidade e 30s com alta intensidade de luz; G3 Kreativ Kuring Light com polimerização gradual por 40s; G4 - argon laser por 10 s. Os dentes foram termociclados por 500 ciclos a $5^{0}$ a $55^{\circ} \mathrm{C}$, com 30 s por ciclo. Após a termociclagem, os dentes foram imersos em solução de azul de metileno a $1 \%$ por $24 \mathrm{~h}$. Os dentes foram seccionados, analisados em estereomicroscópio e a microinfiltração foi medida linearmente de acordo com a porcentagem da infiltração do corante ao longo da margem gengival. Houve diferença estatisticamente significante entre as proporções dos escores de microinfiltração entre os grupos. A técnica de polimerização com baixas intensidades iniciais, utilizada pelo G2, resultou em menor microinfiltração do que o grupo que utilizou o argon laser.

YOSHIKAWA et al. ${ }^{209}$, em 1999, avaliaram o efeito do método empregado para fotopolimerização (polimerização gradual) no selamento e adaptação marginal nas restaurações de resina composta com diferentes valores de fator-C (formas). Cavidades cilíndricas com $1 \mathrm{~mm}$ profundidade por $3 \mathrm{~mm}$ de diâmetro (fator-C $=2.3$ ) ou $1 \mathrm{~mm}$ profundidade por $2 \mathrm{~mm}$ de diâmetro (fator-C $=3$ ) foram preparadas em dentes bovinos (dentina) e restauradas. Os grupos foram divididos de acordo com o material (sistemas adesivos - Photo Bond, Liner Bond II e Super-Bond D Liner; resina composta - Photo 
Clearfil Bright) e a técnica de polimerização utilizada. As restaurações foram polimerizadas da seguinte maneira: $600 \mathrm{~mW} / \mathrm{cm}^{2}$ (distância da fonte-resina de $0 \mathrm{~mm}$ ) por 60 segundos; $270 \mathrm{~mW} / \mathrm{cm}^{2}$ (distância da fonte-resina de $1 \mathrm{~mm}$ ) por 10 segundos, intervalo de 5 segundos e complementação com a aproximação máxima da fonte polimerizadora por mais 50 segundos. Obtidos 10 espécimes para cada grupo, os mesmos foram termociclados e imersos em solução corante. Os resultados mostraram uma relação do aumento nas fendas marginais com o aumento do fator-C e o método de polimerização gradual tendeu a melhorar o selamento e adaptação marginal indiferentemente do sistema adesivo ou tipo de polimerização utilizada.

Em 1999, YOSHIKAWA et al. ${ }^{208}$ avaliaram a influência do fator de configuração cavitária (fator-C) e da diferença na profundidade dentinária na resistência adesiva de resinas compostas em cavidades com diferentes valores para o fator-C. Molares humanos extraídos foram planificados, até a remoção total do esmalte e obtenção de uma superfície dentinária plana: grupo 1 (dentina superficial - fator-C =1), na qual foi realizado um preparo de classe I medindo: $3 \mathrm{~mm}$ de largura $\mathrm{x} 4 \mathrm{~mm}$ de comprimento $\mathrm{x} 2 \mathrm{~mm}$ de profundidade; grupo 2 (dentina profunda - fator- $\mathrm{C}=3$ ). Para a obtenção do grupo 3 (dentina profunda - fator- $\mathrm{C}=1$ ), as paredes laterais do preparo acima descrito foram removidas, obetndo-se uma situação similar à do grupo 1, porém numa profundidade diferente. Os dentes foram então restaurados (aleatoriamente) utilizando três sistemas adesivos (Clearfil Liner Bond II, One Step e SuperBond D Liner) e uma resina composta fotopolimerizável (Clearfil Photo Posterior), obtendo assim 4 espécimes para cada situação (fator-C/profundidade/sistema adesivo). Após 24 horas de armazenamento em água, os espécimes foram seccionados verticalmente em 3 ou 4 fatias, para o teste de micro-tração, a fim de determinar a resistência adesiva do material à parede pulpar nas três situações. Os resultados mostraram alta resistência adesiva na dentina 
superficial (fator-C $=1$ ) para os três sistemas adesivos, porém tanto o One Step quanto o Super-Bond D Liner mostraram decréscimo na resistência adesiva para a situação dentina profunda/fator- $\mathrm{C}=1$. Quando o fator-C foi aumentado para 3 (grupo 2), a resistência adesiva de todos os materiais caiu em média de 21 a 35\%. A análise de microscopia eletrônica de varredura mostrou que os espécimes que exibiram altos índices de resistência adesiva tenderam a exibir falhas coesivas dentro da camada híbrida, enquanto aqueles que exibiram baixa resistência de união mostraram falhas no topo da camada híbrida. Os autores confirmaram nessas condições a redução na resistência adesiva em função do fator-C e da profundidade cavitária.

Em 1999, BOTELHO ${ }^{17}$ realizou um estudo experimental, onde avaliou a microinfiltração marginal em restaurações classe II M.O.D., em pré-molares humanos, utilizando a técnica do "sanduíche". Os materiais testados foram: uma resina composta (Z100) que foi o grupo controle em todas restaurações; o amálgama (Dispersalloy); um cimento de Ionômero de vidro modificado por resina (Vitremer); três resinas compostas modificadas por poliácidos (Dyract e Dyract-AP) e outra possuindo capacidade de liberar flúor (Freedom); e uma resina composta híbrida, radiopaca de ativação química e com baixa viscosidade (Bisfil-2B). Os dentes depois de restaurados foram submetidos a termociclagem e depois imersos em solução traçadora de azul de metileno e análisados depois de seccionados. A infiltração foi medida qualitativamente nas interfaces cervicais cemento/material restaurador e entre os materiais. As conclusões foram as seguintes: O Dispersalloy, Z-100, Freedom e Dyract apresentaram maiores índices de penetração. O Dyract-AP e o Vitremer possuíram um índice considerado reduzido de infiltração e a Bisfil-2B ocupou uma posição intermediária entre os demais. 
Nas pesquisas “in vitro”, muitos testes são realizados na tentativa de similar as constantes variações ocorridas no meio bucal. A termociclagem é utilizada por muitos pesquisadores com esta finalidade. O objetivo do trabalho realizado em 1999 por LAMOSA et $\mathrm{al}^{109}$, foi avaliar o efeito da termociclagem na adesão de um adesivo dentinário de Quinta Geração ( Prime \& Bond 2.1 ) à dentina de dentes humanos, avaliada através da resistência ao cisalhamento e da infiltração marginal. Para os testes de resistência ao cisalhamento 20 corpos-de-prova foram preparados a partir de dentes humanos pré-molares extraídos, incluídos em resina epóxica e divididos aleatoriamente em 2 grupos, por sua vez subdivididos em outros dois. Para os grupos A e 1B, os espécimes foram desgastados com lixa d’água n 400 a 600 até a exposição da dentina. A superfície dentinária previamente demarcada, foi condicionada com ácido fosfórico por 15 segundos, sendo aplicado o Prime \& Bond 2.1 e sobre este, a resina composta fotopolimerizável TPH Spectrum, com o auxílio de uma matriz de teflon. Os grupos 2A e 2B corresponderam aos testes de infiltração marginal. Cavidades de classe $\mathrm{V}$ padronizadas apresentando os bordos incisal em esmalte e cervical em cemento, foram confeccionadas e restauradas com os mesmos materiais citados utilizando-se a técnica incremental. Após a polimerização da resina, os corpos-de-prova foram estocados por sete dias em água destilada à temperatura ambiente. Os sub-grupos $\mathrm{A}$ e $1 \mathrm{~B}$, foram submetidos à termociclagem correspondente a 500 ciclos. Nos demais, a força adesiva foi testada em máquina de ensaios mecânicos. Os corpos-de-pprova do grupo 2 (2 A e 2B ) foram corados por solução de nitrato de prata a $50 \%$ sendo a infiltração marginal avaliada por 2 examinadores, utilizando-se escores de 0 a 3 . Os resultados foram tratados estatisticamente, não se observando-se diferenças significantes entre os grupos termociclados ou não. Os 
autores concluíram que a termociclagem não alterou a força de adesão do sistema adesivo à dentina humana.

O propósito do trabalho desenvolvido por LEÃO et al $^{110}$ apresentando no XIII encontro do Grupo Brasileiro dos Professores de Dentística em 1999, consistiu em avaliar “in vitro" a habilidade do selamento marginal à dentina e ao esmalte, com a utilização de um compômero. Oitenta dentes (caninos e pré-molares) extraídos foram preparados, apresentando as cavidades margens em esmalte e cemento e restaurados com o Dyract AP. Os dentes foram submetidos à termociclagem com variação de temperatura entre $5^{\circ} \mathrm{C}$ e $55^{\circ} \mathrm{C}$ totalizando 500 ciclos. Posteriormente foram seccionados no seu longo eixo, avaliando-se o grau de infiltração marginal. O teste estatístico de Mann-Whitney foi aplicado para verificar a ocorrência ou não de diferença significativa entre os grupos estudados. O nível de significância utilizado nas decisões de todos os testes estatísticos foi de 5\%. A melhor "performance" do Dyract AP, foi observada quando do não condicionamento ácido em dentina seca. Em vista dos resultados, os autores concluíram que a infiltração marginal ocorreu em todos os espécimes em maior ou menor grau, com ligeira vantagem percentual para o substrato seco em relação ao úmido e melhor desempenho do vedamento marginal sem o emprego do condicionamento ácido.

O objetivo do trabalho de DEMARCO et al. ${ }^{46}$, também apresentando ao Grupo Brasileiro Dos Professores de Dentística em 1999, foi avaliar a microinfiltração em cavidades de classe II possuindo paredes cervicais em cemento e restauradas com diferentes técnicas e materiais. Foram preparadas cavidades padronizadas, estritamente proximais utilizando-se terceiros molares humanos recentemente extraídos. A parede cervical foi estabelecida em 
cemento. Todas as cavidades foram condicionadas com ácido fosfórico a 37\% por 20 segundos. As cavidades foram aleatoriamente restauradas em três grupos como se segue: 1 Scothbond MP / resina composta fotopolimerizável Z-100; 2 - Scothbond MP / resina quimicamente ativada Bisfil 2B / resina fotopolimerizável Z-100; 3 - Scothbond MP dual / amálgama / ácido / Scothbond MP dual / resina Z-100. Os dentes restaurados foram armazenados em água destilada por uma semana. Os ápices radiculares foram selados com resina composta e a superfície dos dentes isoladas com esmalte de unha, exceptuando-se as restaurações e $2 \mathrm{~mm}$ ao redor destas, sendo então submetidos à ciclagem térmica nas temperaturas de $5^{\circ} \mathrm{C}$ e $55^{\circ} \mathrm{C}$. Após a termociclagem os dentes foram imersos em solução de azul de metileno a $2 \%$ por 24 horas. Posteriormente os dentes foram seccionados e o grau de infiltração avaliado por dois observadores, com base em escores pré-estabelecidos. Não foram encontradas diferenças estatísticas significantes entre os grupos estudados. 
3 PROPOSIÇÃO 


\section{3 - PROPOSIÇÃO}

Tendo em vista as hipóteses aventadas na introdução e com base na consulta feita na literatura especializada com relação ao aperfeiçoamento do vedamento marginal, especialmente nas áreas localizadas em cemento das restaurações de resina composta de classe II, utilizando a técnica mista, ou seja, associando-a a outros materiais, a presente pesquisa teve como objetivo avaliar :

Qualitativamente, a microinfiltração marginal na interface cemento/material restaurador, empregando a ciclagem mecânica e ciclagem térmica, nas seguintes condições experimentais demonstradas na figura 3.1:

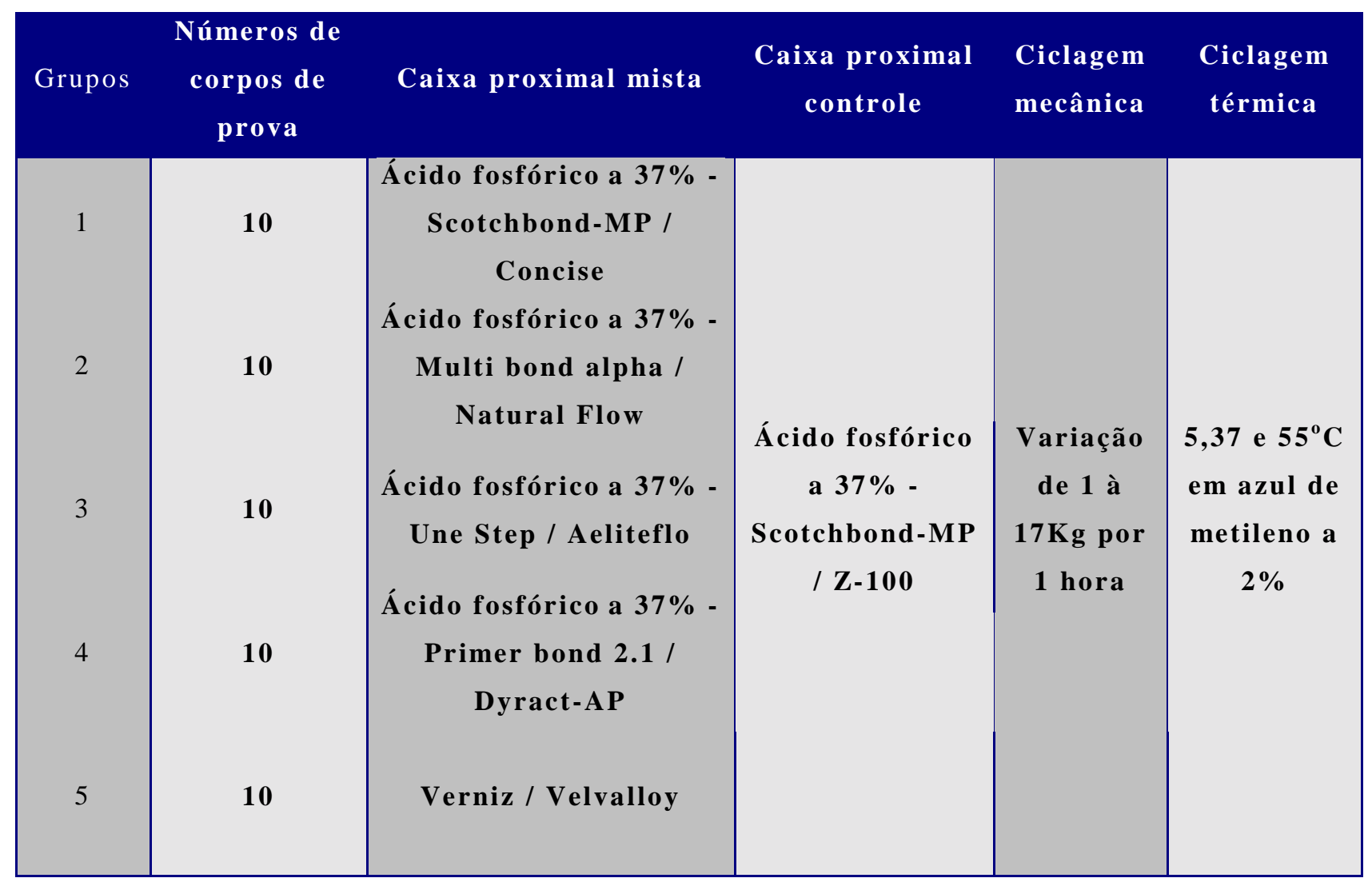

FIGURA 3.1 - Quadro representativo dos grupos experimentais com seus respectivos valores numéricos de corpos de provas, tipo de condicionamento, materiais utilizados nas caixas proximais e os tipos de testes que foram submetidos os grupos experimentais. 
4 MATERIAL E MÉTODOS 


\section{4 - MATERIAL E MÉTODOS}

\section{Planejamento operatório}

Foram realizados experimentos preliminares que tiveram como objetivo auxiliar a sistematização dos passos laboratoriais, ordenando condições experimentais e manobras específicas, englobando o tempo relativo a cada fase operatória, que seriam empregadas nos ensaios definitivos. Isto possibilitou padronizar com precisão a confecção dos corpos de prova de cada grupo experimental e estabelecer uma metodologia cientificamente controlada. Dessa maneira, as fases laboratoriais da pesquisa foram assim distribuídas:

$1^{\underline{a}}$ Fase PRÉ-OPERATÓRIA

$2^{-a}$ Fase TÉCNICA OPERATORIA DE PREPARO DAS CAVIDADES, RESTAURAÇÕES , ACABAMENTO E POLIMENTO

$3^{\text {a }}$ Fase CICLAGEM MECÂNICA POR CARREGAMENTO OCLUSAL

$4^{-a}$ Fase CICLAGEM TÉRMICA

$5^{\text {a }}$ Fase INCLUSÃO E SECCIONAMENTO DOS ESPÉCIMES

$6^{\mathrm{a}}$ Fase AVALIAÇÃO DA INFILTRAÇÃO MARGINAL. 
- $1^{\text {A }}$ FASE - PRÉ-OPERATÓRIA -

A - Seleção dos dentes

B - Preparo dos dentes

\section{A - Seleção dos dentes}

Para o desenvolvimento desta pesquisa, foram utilizados 50 pré-molares superiores humanos, cuja morfologia estrutural apresentava-se isenta de qualquer tipo de fator que pudesse influir nos procedimentos laboratoriais bem como nos resultados. Os dentes foram submetidos à criteriosa seqüência seletiva:

- Deveriam ser recém extraídos por indicação ortodôntica ou periodontal;

- após a extração, deveriam ser armazenados em solução de Formalina 10 \%;

- exame visual, com o auxílio de uma lupa com 4X de aumento, para selecionar os dentes livres de cáries, restaurações, trincas e defeitos estruturais.

Desse modo, foram selecionados 50 pré-molares, apresentando coroas clínicas de forma e tamanho semelhantes, distribuídos em cinco grupos de dez dentes, de acordo com as diferentes condições experimentais descrita na proposição. 
B - Preparo dos dentes

Antecedendo a confecção das cavidades, foram realizados inicialmente a raspagem e o alisamento radicular com instrumentos manuais e a profilaxia das coroas dos dentes com pedra pomes e água, aplicada com escova Robson acoplada a um contra-ângulo, girando a baixa velocidade.

No sentido de impedir posteriormente uma indesejável infiltração de corante pelo forame radicular, este foi vedado com resina composta Z100. Após o vedamento dos ápices radiculares, os dentes foram incluídos com gesso pedra Tipo III em anéis de borracha obtidos de mangueira de alta pressão, previamente seccionados com altura de $6 \mathrm{~cm}$ e 3,8 $\mathrm{cm}$ de diâmetro. Apenas a raiz ficava incluída, deixando a coroa cerca de $2 \mathrm{~mm}$ do colo ou terço cervical, livre de contato com o gesso, possibilitando acesso e visibilidade dessa área (forma de conveniência) para as fases subseqüêntes. 


\section{- ${ }^{\text {A }}$ FASE - PREPARO DAS CAVIDADES, RESTAURAÇÕES, ACABAMENTO E POLIMENTO -}

\section{A - Preparo das cavidades}

Em cada dente selecionado foi confeccionada uma cavidade de Classe II, envolvendo as faces: mesial, oclusal e distal. Por serem as resinas compostas consideradas materiais restauradores temporários e por apresentarem características adesivas, os preparos mésio-ocluso-distais (M.O.D.) foram instrumentados de forma conservadora, seguindo a geometria cavitária sugerida por MONDELLI ${ }^{133,134,135}$ para lesões incipientes, a qual deve apresentar as seguintes características:

\section{- CAIXA OCLUSAL -}

Abertura vestíbulo-lingual estreita, com $1 / 4$ da distância entre os vértices das cúspides;

Paredes vestibular e lingual convergentes para oclusal;

Parede pulpar perpendicular ao eixo longitudinal do dente;

Ângulos diedros e triedros arredondados;

Ângulo cavo-superficial nítido e sem bisel.

\section{- CAIXA PROXIMAL -}

Paredes vestibular e lingual convergentes para oclusal no sentido gengivo-oclusal e ligeiramente divergentes entre si no sentido áxio-proximal, formando ângulo de $110^{\circ} \mathrm{C}$ com a superfície externa dos dentes;

Parede gengival côncava vestíbulo-lingualmente..

Parede axial plana vestíbulo-lingualmente e ligeiramente expulsiva no sentido gengivooclusal; 
Ângulo cavo-superficial nítido e sem bisel;

Ângulos internos arredondados, inclusive o áxio-pulpar;

Contorno externo em forma de "sino" ou de "gota d'agua".

Para que todos os espécimes apresentassem conformação cavitária semelhante em forma e tamanho, evitando que tais diferenças viessem a constituir uma variável possível de influir nos resultados, algumas precauções foram tomadas e pré-estabelecidas. A padronização das dimensões (profundidade, largura e extensão) cavitárias foi alcançada com o auxílio de uma sonda milimetrada; para a sua obtenção, foi utilizada uma broca carbide cone invertido longo de extremo arredondado, \#331 L, girando em alta velocidade sob intensa refrigeração ar/água, sendo substituída a cada cinco dentes. Os preparos apresentaram as dimensões: caixa oclusal - distância vestíbulo-lingual: na altura do istmo, abertura de $1 / 4$ da distância intercuspídea e de $2 \mathrm{~mm}$ na região das cristas marginais; caixa proximal - distância vestíbulo-lingual : $2 \mathrm{~mm}$ de largura na altura da crista marginal e 3 mm de largura na altura do $1 / 3$ cervical; a parede de fundo pulpar tinha $1,5 \mathrm{~mm}$ de profundidade. O segmento proximal de todas as cavidades foi estendido de tal forma que o término da parede gengival ficasse localizado $1,5 \mathrm{~mm}$ além da junção cemento esmalte (em cemento), por ser esta uma área crítica à infiltração marginal, atendendo, assim, aos objetivos propostos na pesquisa. 


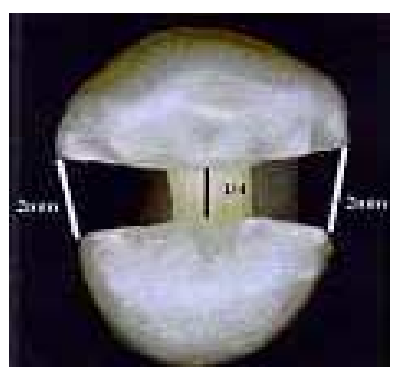

FIGURA 4.1 - Caixa oclusal - distância vestíbulo-lingual: na altura do istmo abertura de 1/4 da distância intercuspídea e de $2 \mathrm{~mm}$ na região das cristas marginais .

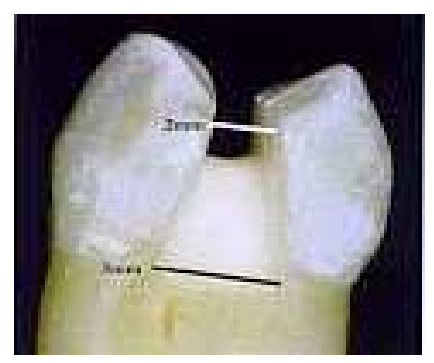

FIGURA 4.2 - Caixa proximal - Distância vestíbulo-lingual : 2 mm de largura na altura da crista marginal e $3 \mathrm{~mm}$ de largura na altura do $1 / 3$ cervical.

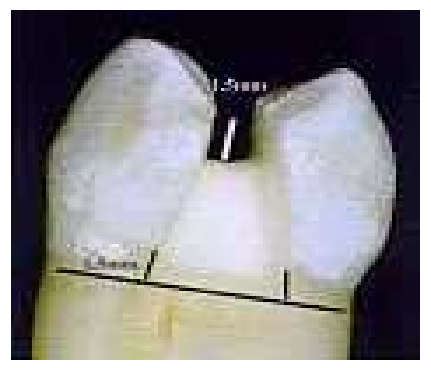

FIGURA 4.3 - A parede de fundo pulpar tinha $1,5 \mathrm{~mm}$ de profundidade. O segmento proximal de todas as cavidades foi estendido de tal forma que o término da parede gengival ficasse localizado $1,5 \mathrm{~mm}$ além da junção cemento esmalte (em cemento), por ser esta uma área crítica à infiltração marginal, atendendo, assim, aos objetivos propostos na pesquisa. 


\section{Acabamento:}

Para o acabamento das paredes circundantes, a mesma broca $331 \mathrm{~L}$ foi utilizada, desta vez adaptada para girar a baixa velocidade. Um recortador de margem cervical \# 27 foi também utilizado para remover prismas de esmalte friáveis, na margem da parede gengival, bem como no arredondamento do ângulo áxio-pulpar. 


\section{B - Restaurações dos dentes}

Para a confecção das restaurações, foram utilizados os materiais discriminados na figura 4.4:

\begin{tabular}{|c|c|c|c|c|}
\hline Marca comercial & Fabricante & Lote & Característica & Ativação \\
\hline Z-100 & 3M Dental Products & $6 \mathrm{AT}$ & Resina híbrida & Foto \\
\hline Scotchbond MP & 3M Dental Products & $7 \mathrm{JB}$ & Adesivo dentinário & Foto \\
\hline Concise & 3M Dental Products & RJ 1 & Resina de macropartículas & Química \\
\hline Scotchbond MP & 3M Dental Products & RJ1 & Adesivo dentinário & Química \\
\hline Natural Flow & DFL & 9706599 & $\begin{array}{c}\text { Resina composta de micropartícula de } \\
\text { baixa viscosidade }\end{array}$ & Foto \\
\hline Mult bond alpha & DFL & 9607144 & Sistema adesivo & Dual \\
\hline Aeliteflo & Bisco & 069266 & $\begin{array}{c}\text { Resina composta de micropartícula de } \\
\text { baixa viscosidade }\end{array}$ & Foto \\
\hline One Step & Bisco & 129195 & Adesivo esmalte / dentina & Foto \\
\hline Dyract AP & Dentsply & 1999-06 & Resina modificada por poliácido & Foto \\
\hline Prime \& Bond 2.1 & Dentsply & 35838 & Adesivo esmalte / dentina & Foto \\
\hline Velvalloy & S.S. White & OUC & Amálgama convencional & - \\
\hline Tanari Mercúrio & Dental Brand Ltda & - & Mercúrio tri-destilado & - \\
\hline Copalite & Hager \& Meinsinger & $3972 \mathrm{Cx} 127$ & Resina copal e sintética & - \\
\hline
\end{tabular}

FIGURA 4.4 - Quadro demonstrativo dos materiais utilizados, fabricantes, lotes, características e ativação. 


\section{Técnica de restauração de cada grupo.}

A fase restauradora foi realizada em duas etapas: primeiramente, em um dos segmentos proximais dos preparos foram na porção gengival os materiais escolhidos para serem testados pela técnica mista; numa segunda etapa, foi inserida nas caixas oclusal e proximal do lado oposto e na porção restante do segmento experimental a resina fotopolimerizada Z100. Assim, o segmento proximal oposto da restauração constituía o controle em relação ao segmento experimental composto de materiais diferentes.

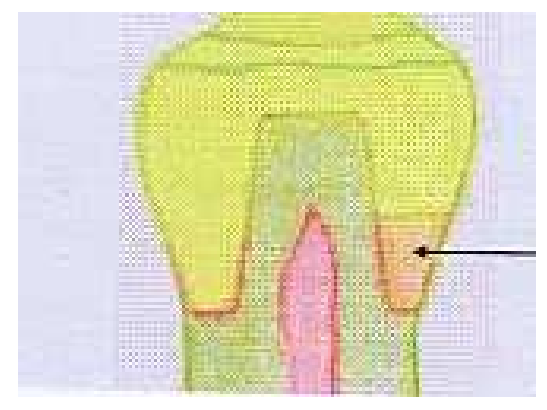

FIGURA 4.5 - Esquema ilustrativo de uma secção mesio-distal do dente depois de restaurado. Notar, numa das caixas proximais, a associação de materiais restauradores (seta). 
- "Grupo controle" -

- Sistemas restauradores utilizados -

Sistema restaurador adesivo Scothbond-MP / Z-100 fotopolimerizável

Este grupo não existiu individualmente, porque esta condição estava presente em todas restaurações, mais particularmente em todos os espécimes que constituiam os grupos experimentais. Isto porque, em todos eles, uma das caixas proximais e oclusal foram restauradas convencionalmente, com adesivo Scotchbond-MP e resina composta Z-100, enquanto o outro segmento proximal foi restaurado pela técnica mista, isto é, associando outros materiais restauradores, que eram inseridos ou condensados na porção gengival e, o restante, com a mesma resina composta fotopolimerizada Z100.

Materiais utilizados:

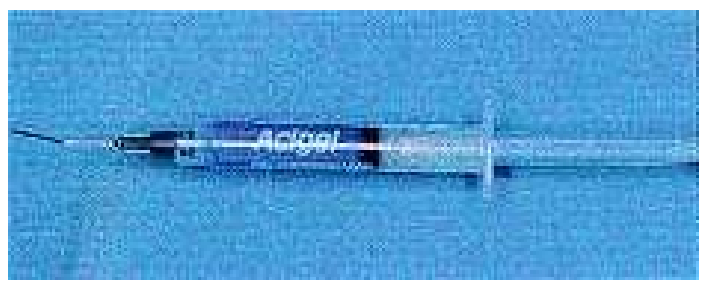

FIGURA 4.6 - Ácido fosfórico a 37\% 


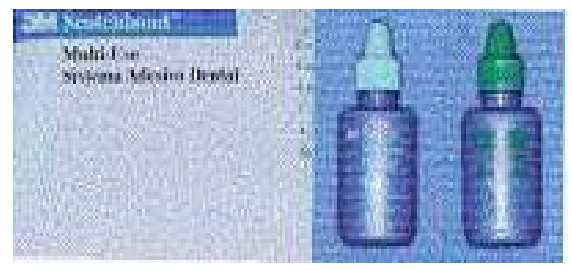

FIGURA 4.7 - Sistema Adesivo Dental Multi-uso - Scothbond Primer: é composto de uma solução aquosa de HEMA e copolímero de ácido polialquenóico. Possui um $\mathrm{pH}$ de aproximadamente 3,3. Segundo o fabricante, a incorporação do copolímero reduz significantemente a sensibilidade à umidade Scotchbond Adesivo: consiste uma resina fotopolimerizável, composta por Bis-GMA, HEMA e Fotoiniciadores.

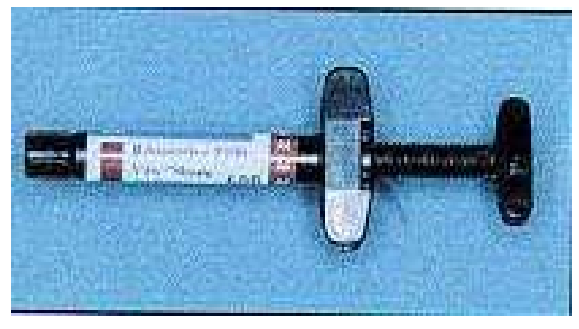

FIGURA 4.8 - Resina Composta Z-100: resina composta híbrida fotopolimerizável. A resina deste sistema restaurador consiste de um bisphenol-A glicidilmetacrilato (Bis-GMA) e trietileno glicol dimetilcrilato (TEGMA). Este produto apresenta um sistema inovador patenteado, tratando-se de um material sintético de zircônia/sílica. A polimerização do material inicia-se pela exposição à luz visível (especificamente na faixa de 400 a 500 nanômetros de espectro visível). 
Pelo fato da cavidade ser considerada de média profundidade, a limpeza foi realizada simultaneamente com a hibridização, pois, segundo MONDELLI ${ }^{134}$, em cavidades superficiais, rasas e de média profundidade, para resina composta, a limpeza cavitária é realizada com o ataque ácido total (ácido fosfórico a 37\%) e a proteção do complexo dentinopulpar pela hibridização pelo sistema adesivo.

Em seguida, deu-se sequiência à técnica restauradora, de acordo com as exigências previstas para cada condição experimental. É conveniente salientar que todos os materiais foram utilizados seguindo rigorosamente as recomendações dos respectivos fabricantes.

Após a inserção do material escolhido na porção gengival da caixa proximal, a resina composta Z-100 foi colocada seguindo a técnica incremental sugerida por LUTZ et $\mathrm{al}^{119}$

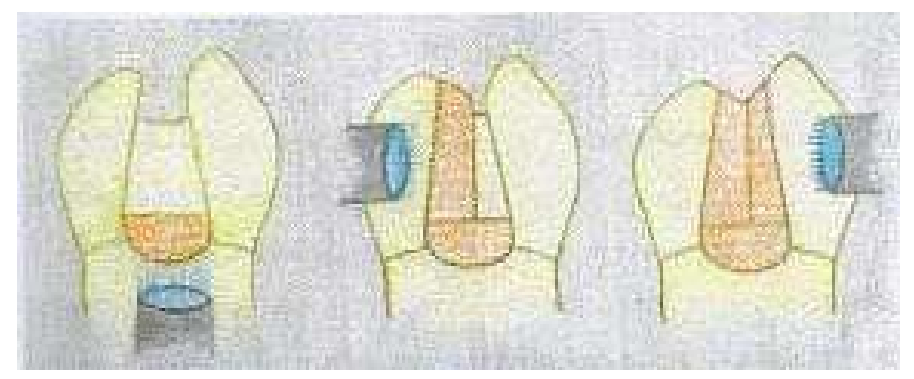

FIGURA 4.9 - Direção de polimerização, por camadas de acordo com a técnica incremental LUTZ et al ${ }^{119}$. 


\section{- Grupo 1 -}

\section{- Sistemas restauradores utilizados -}

Condicionamento ácido + sistema adesivo polimerizado quimicamente Scotchbond-MP Concise + resina composta quimicamente polimerizada Concise + sistema adesivo Scotchbond-MP + resina composta Z-100;(figura 4.10)

Além dos materiais utilizados no grupo controle, foram empregados:

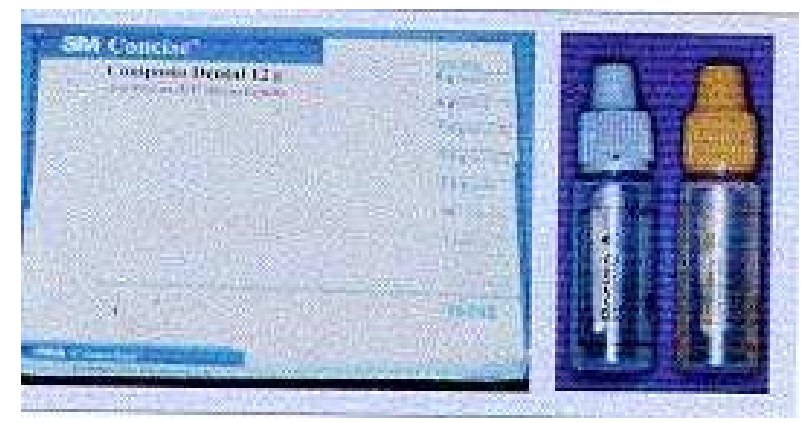

FIGURA 4.10 - Sistema adesivo Scotchbond-MP da resina Concise. Scotchbond Adesivo: consiste numa resina ativada quimicamente, composta por Bis-GMA, HEMA. Resina composta Concise. A parte orgânica é o bis-GMA (BisGlicidilmetacrilato) ou resina de Bowen, a parte inorgânica ou a carga são partículas de quartzo. O quartzo está presente na proporção de $74 \%$ com tamanho médio de 8 micrômetros. 
Esta resina é ativada quimicamente e dividida em duas pastas: (figura 4.11)

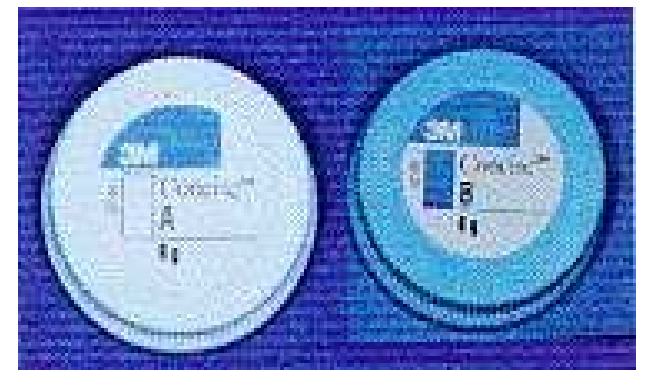

FIGURA 4.11 - Pasta A - é conhecida como Universal, além dos constituintes resina e carga, destaca-se também o Dimetil p-toluidina, que é o acelerador da reação. Pasta B - Contém o Peróxido de Benzoila que é o catalizador, além dos constituintes mencionados. 


\section{Procedimentos restauradores para o grupo 1}

$1^{1}$ etapa: Inicialmente, foi realizado o condicionamento ácido apenas na parede gengival, com o ácido fosfórico a 37\%, aplicado por 30 segundos. As superfícies condicionadas foram lavadas com jatos de ar/água por 30 segundos, recebendo em seguida leves jatos de ar durante 5 segundos. O sistema adesivo empregado para esta condição experimental foi o Sctchbond-MP ativado quimicamente (Concise), que se apresenta em dois tubos A e B, tendo como característica principal o sistema de polimerização química. Após o condicionamento, o adesivo foi dispensado nos casulos do conjunto, uma gota do tubo A e uma gota do tubo B como recomenda o fabricante; com pontas infusoras ou aplicadores descartáveis as gotas do adesivo foram misturadas, manipuladas e pinceladas sobre as paredes cavitárias proximais em questão, obtendo-se uma superfície brilhante.

A partir deste momento, a cavidade foi contornada por uma matriz de poliéster, a qual foi corretamente adaptada na área cervical, para evitar extravasamento e conseqüente excesso de material nessa região. A resina composta quimicamente polimerizável foi então inserida, preenchendo até a altura da junção amelo-cementária com o auxílio de uma espátula especial para resina composta.

$2^{\mathrm{a}}$ etapa: Depois da polimerização química da resina Concise na região cervical, foi feito o condicionamento ácido das paredes cavitárias remanescentes com o ácido fosfórico a $37 \%$ por 30 segundos, sobre a superfície dentinária, resina química e esmalte, ultrapassando ligeiramente o ângulo cavo-superficial em esmalte. As superfícies condicionadas foram então lavadas com jatos de ar/água por 30 segundos, recebendo em seguida leves jatos de ar durante 5 segundos, sem entretanto desidratar a superfície dentinária. O sistema adesivo empregado para esta segunda etapa foi o Sctchbond- 
MP.(Fotoativado) Após o condicionamento, lançando mão dos aplicadores descartáveis pincelou-se sobre as paredes cavitárias a primeira camada de Scothbond primer, aguardando-se 30 segundos; em seguida efetuou-se uma suave secagem com jatos de ar, correspondente a 5 segundos, para que a nova camada deste produto fosse aplicada, obtendo-se imprescindivelmente uma superfície brilhante. O segundo passo constituiu-se na aplicação de uma nova camada do adesivo Scotchbond, sobre o qual foi aplicado um leve jato de ar, espalhando-o de maneira a conseguir uma fina película e uniforme, sendo o mesmo fotopolimerizado por 20 segundos, com o aparelho de luz halógena, empregado em todos os grupos. A resina composta fotopolimerizável Z-100 foi inserida como descrito previamente no grupo controle.

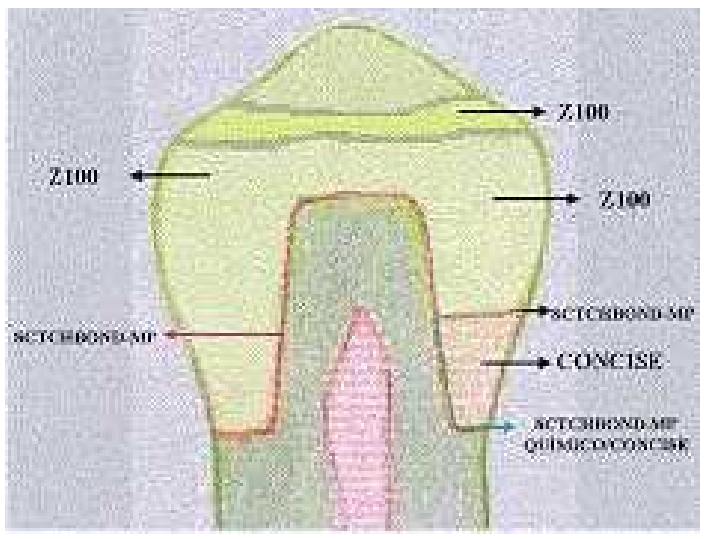

FIGURA 4.12 - Esquema representativo de um corte mésio-distal de um dente restaurado, demonstrando a disposição dos materiais utilizados do grupo 1. 


\section{- Grupo 2 -}

\section{- Sistemas restauradores utilizados -}

Condicionamento ácido + sistema adesivo Multi Bond Alpha + resina composta fotopolimerizável de baixa viscosidade Natural Flow + sistema adesivo Scotchbond MP + resina composta Z-100; (figuras 4.13 e 4.14).

Além dos materiais utilizados no grupo controle, foram empregados:

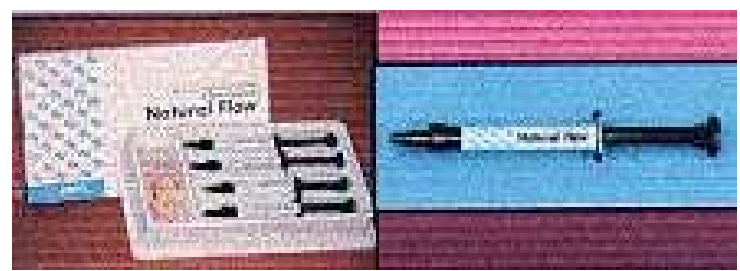

FIGURA 4.13 - Natural Flow - resina composta fotopolimerizável de micropartícula com baixa viscosidade

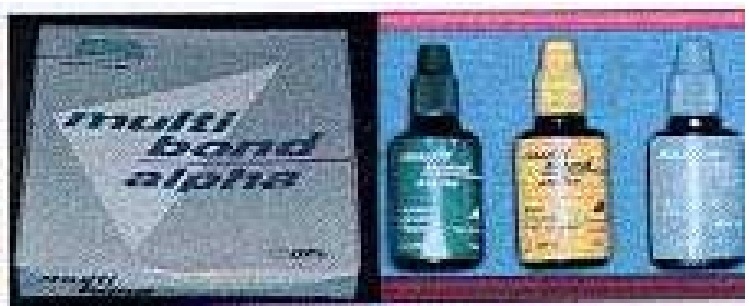

FIGURA 4.14 - Sistema adesivo Multi Bond Alpha - sistema adesivo dental multi uso Hidrofílico - Cura dual composto de PMGDM com sal de magnésio do NTG-GMA 


\section{Procedimentos restauradores para o grupo 2}

$1^{\text {a }}$ etapa: $\mathrm{O}$ primeiro passo constituiu-se no condicionamento ácido de toda a cavidade, exatamente como descrito para grupo 1. Foram pincelados cincos camadas (A+B) do Multi Bond Alpha, com os aplicadores descartáveis, mantendo-o em repouso por 30 segundos, realizando-se em seguida ligeira secagem por 5 segundos. Foi pincelada em seguida uma fina camada do adesivo resinoso Bond Base parte 1 e em seguida inserida a resina Natural Flow, na porção gengival, com o auxílio de uma espátula especial para resina composta, preenchendo até a altura da junção amelo-cementária e, por fim, fotopolimerizada por 60 segundos.

$2^{\mathrm{a}}$ etapa: Posteriormente foi realizado o complemento da restauração da cavidade com resina composta Z100, como descrito no grupo 1 .

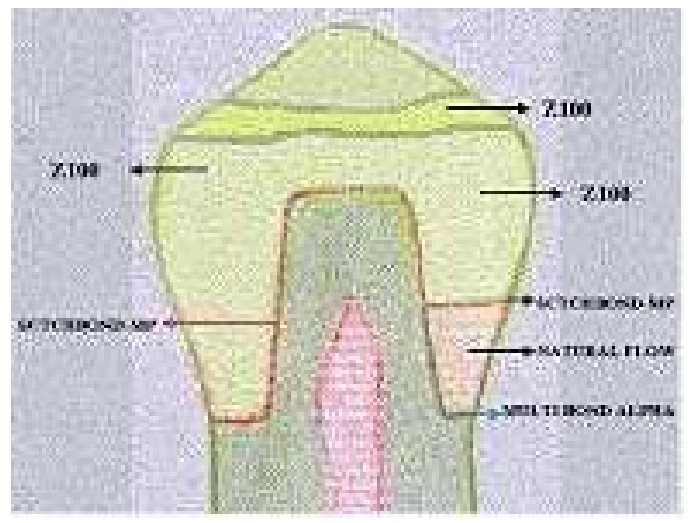

FIGURA 4.15 - Esquema representativo de um corte mésio-distal de um dente restaurado, demonstrando a disposição dos materiais utilizados do grupo 2 . 


\section{- Grupo 3 -}

\section{- Sistemas restauradores utilizados -}

Condicionamento ácido + sistema adesivo One Step + resina composta fotopolimerizável de baixa viscosidade Aeliteflo + sistema adesivo Scotchbond MP + resina composta Z-100. (figuras 4.16 e 4.17 )

Além dos materiais utilizados no grupo controle, foram empregados:

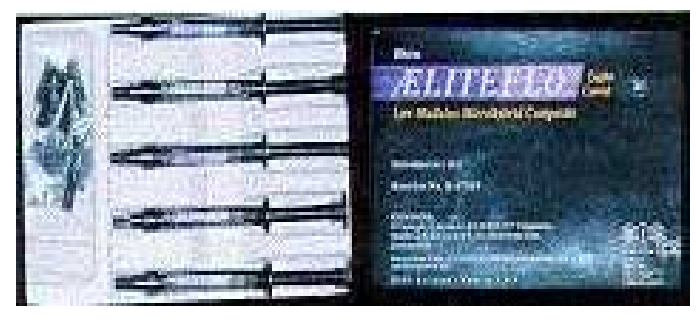

FIGURA 4.16 -Aeliteflo. Resina composta fotopolimerizável de micropartícula com baixa viscosidade

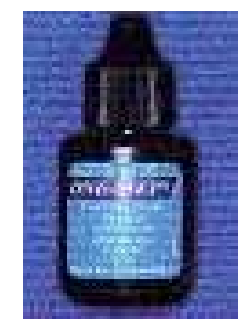

FIGURA 4.17 - Sistema adesivo universal One Step. Possui um sistema adesivo simplificado pelo método de união dos componentes primer e adesivo em um único frasco, One Step Adesivo, contendo monômeros BPDM patenteados pela Bisco e monômeros hidrofílicos em um solvente à base de acetona. 


\section{Procedimentos restauradores para o grupo 3}

$1^{\text {a }}$ etapa: $\mathrm{O}$ primeiro passo constituiu-se no condicionamento ácido de toda a cavidade, exatamente como descrito para grupo 1 . Foi pincelada uma fina camada do One Step, com os aplicadores descartáveis, mantendo-a em repouso por 30 segundos, realizando-se em seguida ligeira secagem por 5 segundos. Aplicação de uma nova camada do adesivo, sendo esta imediatamente espalhada com um leve jato de ar e, em seguida, fotopolimerizada por 10 segundos. A resina Aeliteflo foi então inserida, na porção gengival, com o auxílio de uma espátula especial para resina composta (número), preenchendo até a altura da junção amelo-cementária e, por fim, fotopolimerizada por 60 segundos.

$2^{\mathrm{a}}$ etapa: Posteriormente foi realizado o complemento da restauração da cavidade com resina composta Z100, como descrito no grupo 1 .

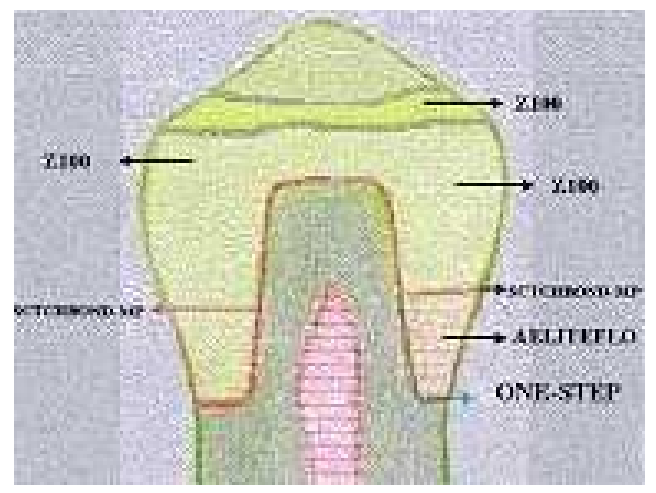

FIGURA 4.18 - Esquema representativo de um corte mésio-distal de um dente restaurado, demonstrando a disposição dos materiais utilizados do grupo 3 . 


\section{- Grupo 4 -}

\section{- Sistemas restauradores utilizados -}

Condicionamento ácido + sistema adesivo Prime \& Bond $2.1+$ resina composta modificada por poliácido Dyract-AP + sistema adesivo Scotchbond-MP + resina composta Z-100; (figura 4.19)

Além dos materiais utilizados no grupo controle, foram empregados:
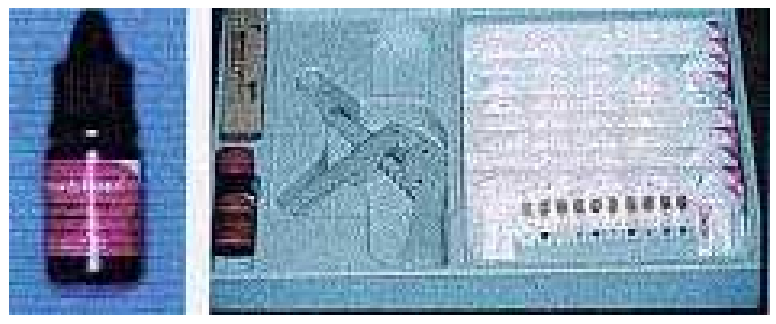

FIGURA 4.19 - Prime \& Bond 2.1. Agente de união multiuso fotopolimerizável, com flúor monocomponente para esmalte e dentina, composto por resinas dimetacrilato. Elastoméricas (monofosfato de dipentaleritritol pentacrilato), UDMA, fotoiniciadores, estabilizadores, hidrofluoreto de cetilamina e acetona. Este sistema combina primer e adesivo em um único frasco.

Dyract-AP : resina composta modificada por poliácido. Para restaurações anteriores e posteriores. Este sistema restaurador, é composto por resinas polimerizáveis, resina TCB, iniciadores foto sensíveis e estabilizadores ${ }^{52}$. 


\section{Procedimentos restauradores para o grupo 4}

$1^{1}$ etapa: $\mathrm{O}$ primeiro passo constituiu-se no condicionamento ácido na porção cervical, exatamente como descrito para grupo 1. Foi pincelada uma fina camada do Prime \& Bond 2.1, com os aplicadores que acompanham o conjunto do material, mantendo-a em repouso por 30 segundos, realizando-se em seguida ligeira secagem por 5 segundos. Aplicação de uma nova camada do adesivo, sendo esta imediatamente espalhada com um leve jato de ar e, em seguida, fotopolimerizada por 10 segundos. O Dyract-AP foi então inserido, na porção gengival, com o auxílio da seringa tipo Centrix, que também acompanha o conjunto, preenchendo até a altura da junção amelo-cementária e, por fim, fotopolimerizado por 40 segundos.

$2^{\underline{a}}$ etapa: Posteriormente foi realizado o complemento da restauração da cavidade com resina composta Z100, como descrito no grupo 1.

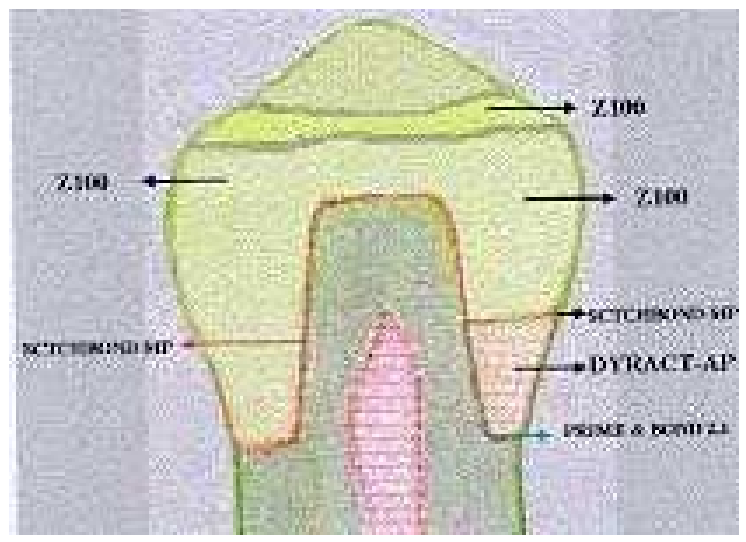

FIGURA 4.20 - Esquema representativo de um corte mésio-distal de um dente restaurado, demonstrando a disposição dos materiais utilizados do grupo 4 . 


\section{- Grupo 5 -}

\section{- Sistemas restauradores utilizados -}

Verniz cavitário Copalite + amálgama convencional Velvalloy + condicionamento ácido + sistema adesivo Scotchbond-MP + resina composta Z-100. (figura 4.21)

Além dos materiais utilizados no grupo controle, foram empregados:

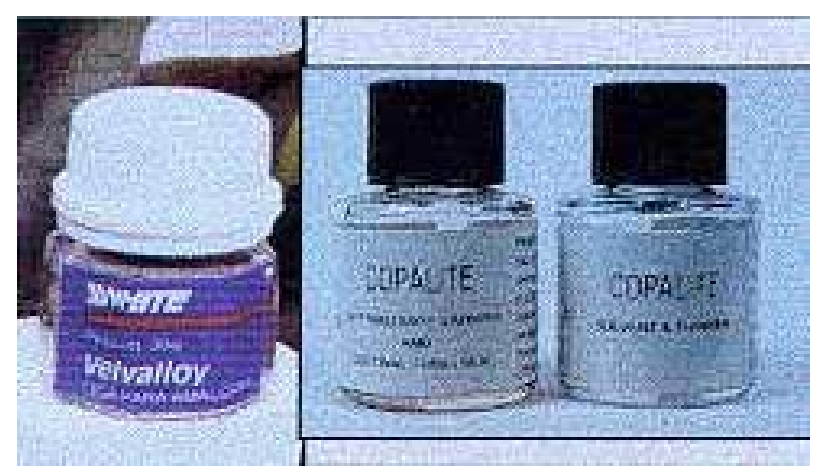

FIGURA 4.21 -Amálgama convenvional Velvalloy e Copalite: verniz cavitário à base de verniz de copal, constituído por resina natural de copal, dissolvida em solvente orgânico. 


\section{Procedimentos restauradores para o grupo 5}

Neste grupo, as cavidades tiveram o $1 / 3$ cervical de sua caixa proximal restaurado com o amálgama Velvalloy.

$1^{1}$ etapa: Inicialmente foi feita a limpeza da porção gengival como sugerido por MONDELLI ${ }^{131}$ com uma solução à base de clorexidina Posteriormente foi realizada a aplicação de duas camadas do verniz Copalite, por meio de aplicadores descartáveis. Para a secagem da primeira camada de verniz, leves jatos de ar foram dispensados sobre esta, enquanto deixou-se secar espontaneamente a segunda camada. Procedeu-se em seguida a dosagem e trituração do amálgama; para essa finalidade, a limalha e o mercúrio foram pesados na proporção 1:1, numa balança Crandall, e depois colocados em uma cápsula plástica contendo um pequeno pistilo metálico triturados em um amalgamador eletrônico por período de 7 segundos. A inserção do amálgama na cavidade foi realizada com o auxílio de um porta-amálgama de uso odontopediátrico, posicionado na caixa proximal e manualmente condensado por meio de um calcador $\mathrm{n}^{\mathrm{o}} 1$ de Ward, ocupando terço gengival de $2 \mathrm{~mm}$ das caixas proximais. Os excessos de material foram removidos com uma espátula Hollenback \# 3S.

$2^{\underline{a}}$ etapa: Posteriormente foi realizado o complemento da restauração da cavidade com resina composta Z100, como descrito no grupo 1. 


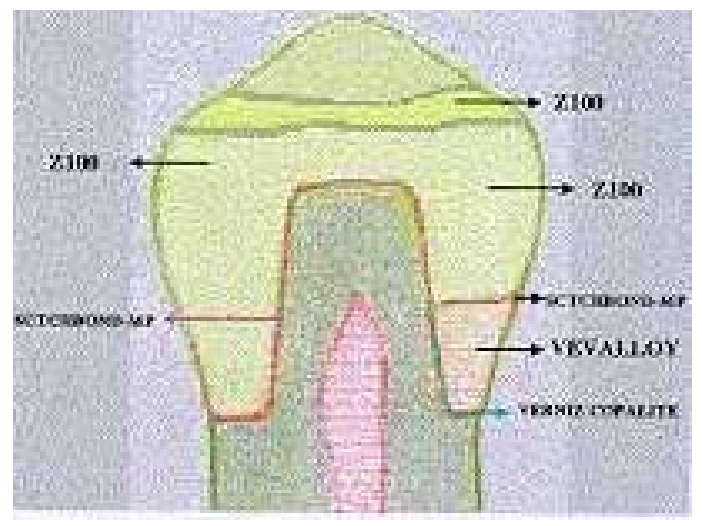

FIGURA 2.22 - Esquema representativo de um corte mésio-distal de um dente restaurado, demonstrando a disposição dos materiais utilizados do grupo 5. 


\section{C- Acabamento e polimento das restaurações}

Para todos os grupos, logo após a polimerização do último incremento de resina composta realizou-se o acabamento das margens da restauração, com uma lâmina \# 15, adaptada ao cabo do bisturi, com a finalidade de remover eventuais excessos de material, principalmente na região cervical. Após restaurados, os espécimes foram armazenados em água destilada e mantidos a uma temperatura de $37^{\circ} \mathrm{C}$ em estufa por um período correspondente a 48 horas.

Decorrido o intervalo, as restaurações foram polidas com discos Sof-Lex de granulometria seqüêncial, deixando as restaurações completamente lisas e livres de excessos. No grupo 5, a restauração de amálgama foi finalizada com o auxílio de brocas multilaminadas para acabamento de amálgama e polidas com borrachas abrasivas especiais para polimento de amálgama em pedra-pomes e água. 


\section{- ${ }^{\text {A }}$ FASE - CICLAGEM MECÂNICA POR CARREGAMENTO OCLUSAL -}

Imediatamente após o polimento, com o uso de uma máquina de ensaios universal Kratos, foram aplicadas alternadamente cargas de $1 \mathrm{~kg}$ e $17 \mathrm{~kg} . \mathrm{com}$ uma velocidade regulada a $5 \mathrm{~mm} / \mathrm{min}$;; para essa finalidade regularam-se os índices das seguintes maneiras:

- Comparadores de carga na chave seletora de leitura do display (indicador digital de força). O índice do comparador 1 da máquina foi regulado em $1 \mathrm{~kg}$ (COMP1 =1) e o índice do comparador $2 \mathrm{em} 17 \mathrm{~kg}($ COMP $2=17)$;

- Com as duas chaves referentes a cada COMP negativas ;

- A chave de tração no positivo ;

- Na escala 1 da célula de carga número dois ;

- Botão de ciclagem acionado.

Este recurso permitiu à máquina de ensaios aplicar estes índices de carga alternadamente, num ciclo que durava 18 segundos. O conjunto anel/gesso/dente foi então colocado sobre a plataforma fixa inferior da máquina de ensaios; na plataforma superior móvel da máquina, foi acoplada a célula de carga $\mathrm{n}^{\mathrm{0}} 2$, onde um pino metálico foi preso por rosqueamento. A extremidade inferior do pino, torneada de forma cônica alojava uma esfera de aço ( $2 \mathrm{~mm}$ de diâmetro) que era posicionada na fosseta mesial e posteriormente na distal. Iniciou-se o ciclo de carregamento de compressão por 30 minutos na fosseta mesial e depois, mais 30 na fosseta distal, totalizando 200 ciclos. Sobre a superfície externa 
do dente era colocado um algodão embebido em água destilada, para amenizar a desidratação do dente durante o processo de ciclagem mecânica.

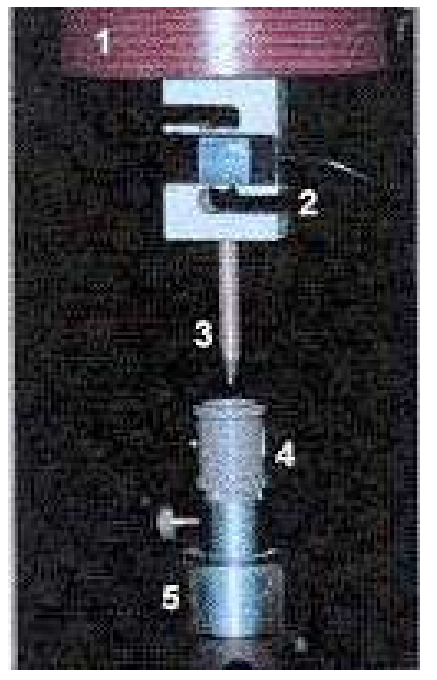

FIGURA 4.23 - Posição do carregamento de ciclagem-mecânica espécime posicionado corretamente

Após a ciclagem mecânica, os espécimes foram armazenados em água destilada e mantidos à temperatura de $37^{\circ} \mathrm{C}$ em estufa por período correspondente à 24 horas. 


\section{- $4^{\text {A }}$ FASE -CICLAGEM TÉRMICA -}

Decorrido o intervalo de 24 horas do término da ciclagem mecânica, os dentes já removidos do cilindro de gesso foram cobertos por duas camadas de esmalte para unha com exceção de $1 \mathrm{~mm}$ aquém e além da interface entre dente/restauração. Este procedimento tem a mesma finalidade já relatada com relação ao forame apical, ou seja, evitar a penetração do corante em áreas indesejáveis recobertas pelo esmalte.

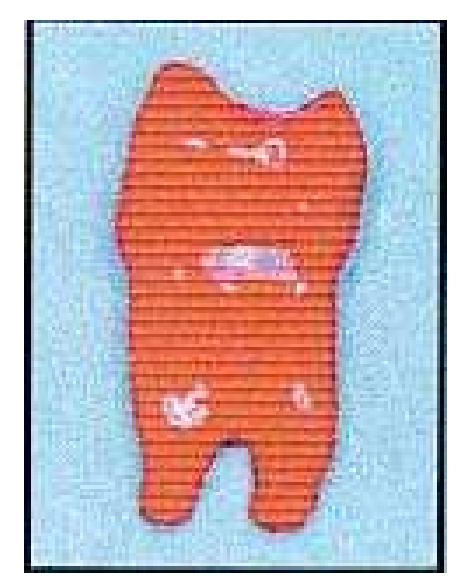

FIGURA 4.24 - Dente coberto com esmalte, com exceção de $1 \mathrm{~mm}$ aquém e além da interface entre dente/restauração.

Imediatamente após a completa secagem do esmalte, o equipamento de ciclagem foi preparado, sendo os espécimes submetidos à termociclagem a $\left(5^{\circ} \mathrm{C}, 37^{\circ} \mathrm{C}\right.$ e $\left.55^{\circ} \mathrm{C}\right)$ em azul de metileno a $2 \%$, sendo que as temperaturas eram mantidas com o auxílio de plastificador de godiva e uma tigela com gelo, correspondendo a 180 ciclos, com banhos de 15 segundos na solução, em cada temperatura, as quais eram checadas durante o experimento com um termômetro de mercúrio, intuito de evitar diferenças nas temperaturas pré-estabelecidas. 
O processo de ciclagem térmica é comumente utilizado em estudos in vitro, com o propósito de criar uma tensão na interface dente/restauração, devido às diferenças nos valores dos coeficientes de expansão térmica linear entre a estrutura dentária e o material restaurador.

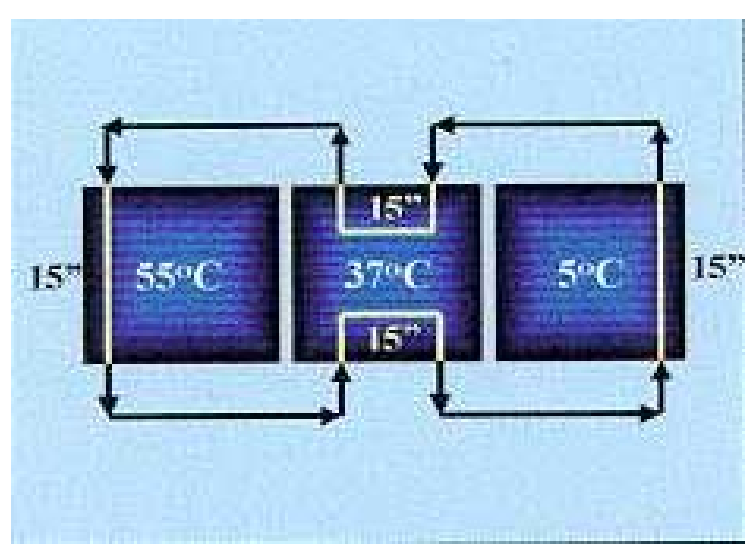

FIGURA 4.25 - Esquema demonstrativo do ciclo da ciclagem térmica

Após a ciclagem térmica, os espécimes foram armazenados em azul de metileno a $2 \%$ mantidos à temperatura de $37^{\circ} \mathrm{C}$ em estufa por período correspondente a 24 horas. 


\section{- $5^{\mathrm{A}}$ FASE - INCLUSÃO E SECCIONAMENTO DOS ESPÉCIMES -}

Concluído o período desejado de imersão no corante, os espécimes foram copiosamente lavados em água corrente pelo mesmo período. Os dentes foram numa base cilíndrica de resina poliestirênica autopolimerizável, obtida de um molde pré-fabricado de silicona, com medidas apropriadas para a adaptação na máquina de corte. Para a inclusão empregou-se uma resina ativada quimicamente. Depois de manipulada, essa resina foi inicialmente vertida em pequenas quantidade no interior das bases, onde os espécimes foram previamente posicionados com a face vestibular ou lingual da coroa dentária voltada para o fundo da base de resina plástica, para que as secções pudessem ser longitudinalmente realizadas no sentido mésio-distal.

\section{Seccionamento dos espécimes}

Cada base acrílica contendo os dentes incluídos foi posicionada e presa à máquina de corte Extec Labcut 1010, o mais perpendicular possível a lâmina do disco diamantado (Extec XL 2205-4”X”012X1/2 HIGH CNCNTRN), para que secções mésio-distais fossem obtidas.

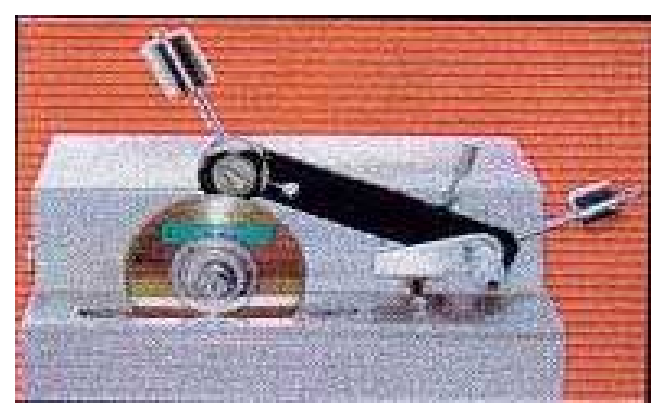

FIGURA 4.26 - Máquina de corte Extec Labcut 1010 (Excel Technologies, Inc. - USA). 
Foram conseguidas para cada espécime cerca de três secções, com espessura de 1 mm. Esta espessura era previamente determinada, com o auxílio de um dispositivo específico da máquina de corte. Os cortes foram realizados em uma velocidade de $300 \mathrm{rpm}$, sob refrigeração a água. Cada grupo foi codificado com uma etiqueta adesiva, para que pudesse ser identificado após a avaliação.

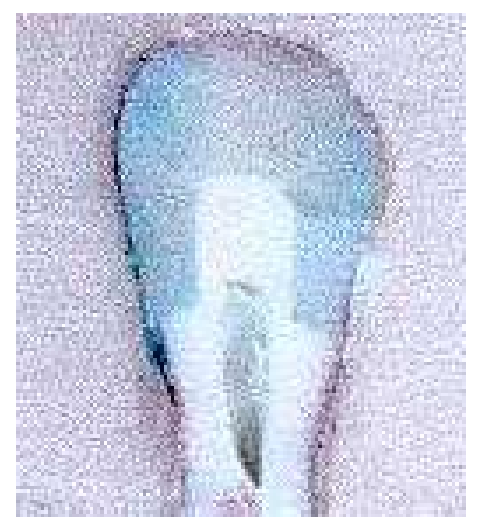

FIGURA 4.27 - Exemplo de secção obtida com a máquina de corte. 


\section{- $6{ }^{\mathrm{a}}$ FASE -AVALIAÇÃO DA INFILTRAÇÃO MARGINAL -}

\section{Método de avaliação}

A microinfiltração na interface restauração/cemento foi avaliada de forma qualitativa. O índice de penetração do corante foi atribuído, adotando-se o critério de escores diversos, previamente determinados segundo BASSIOUNY ${ }^{8}$ :

0 - Nenhuma infiltração

1 - Infiltração do corante até metade da parede gengival

2 - Infiltração em toda parede gengival atingindo a parede axial

3 - Infiltração na parede axial e em direção a polpa

Para os passos seguintes, o corte representativo do maior grau de infiltração, correspondente a cada espécime, foi selecionado, codificado e observado por dois examinadores devidamente calibrados, os quais não participaram das etapas anteriores desta pesquisa nem conheciam o código para identificação dos corpos-de-prova. Os cortes codificados foram então avaliados quanto ao grau de infiltração da solução de azul de metileno a $2 \%$, como pré-determinado, com o auxílio de um fotomicroscópio ótico (Carl Zeiss-Obelochen, Alemanha), utilizando-se uma objetiva de 4x, sendo o aumento resultante correspondente a 62,5 vezes. A análise dos espécimes foi realizada individualmente e, em caso de discordância entre os examinadores, estes se reuniam para nova avaliação, até a obtenção em comum acordo do resultado,. 
Os resultados obtidos foram organizados, para que pudessem ser submetidos ao tratamento estatístico, com o objetivo de verificar a existência de diferenças significantes entre os diversos grupos avaliados.

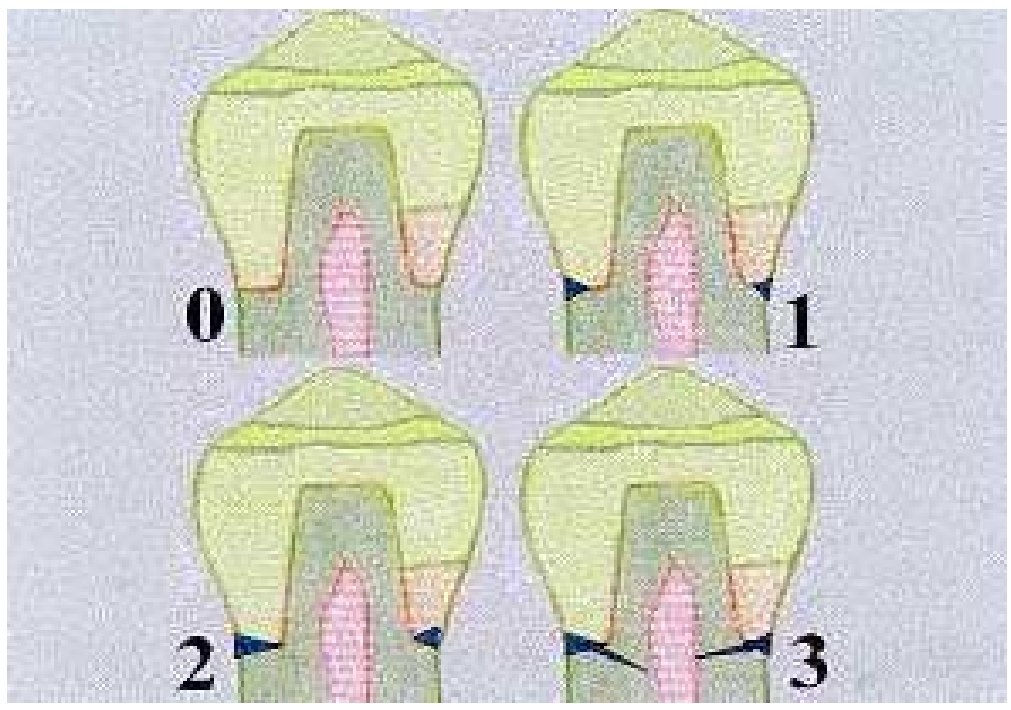

FIGURA 4.28 - Figuras representativas dos escores obtidos. 
5 RESULTADOS E DISCUSSÃO 


\section{5 - RESULTADOS E DISCUSSÃO}

\subsection{Metodologia adotada}

A realização dos experimentos preliminares baseou-se em resultados de estudos divulgados por inúmeros autores constantes na literatura especializada 1, 3, 11, 25, 28, 31, 57, 74, 103, 164, 165, 166, 179, 181, 189, 198 . Esses resultados são representativos da interação entre materiais e técnicas empregados para verificar e avaliar a eficiência de restaurações quanto à infiltração marginal. Segundo KIDD ${ }^{103}$ em 1976, a microinfiltração pode ser definida como a passagem de bactérias, fluídos, moléculas, ou íons na interface estrutura dentária/material restaurador. Problemas como cáries secundárias, descoloração marginal, hipersensibilidade, e a biocompatibilidade dos materiais, caracterizado por alterações pulpares ou não, são fatores diretamente relacionados com a microinfiltração.

Para esse tipo de teste a maioria das investigações utilizam restaurações diretas e "in vitro”, sendo poucas as pesquisas que avaliaram restaurações indiretas como a de DIETSCHI et $\mathrm{al}^{48}$,em 1995. O estudo da infiltração em restaurações “in vivo” é ainda mais difícil de se encontrar na literatura ${ }^{67,103}$, porém existe alguns estudos longitudinais ${ }^{66,126}$ que apresentam dados comparativos de microinfiltração em restaurações "in vitro" e "in vivo”.

Os dentes utilizados nas pesquisas “in vitro" em grande maioria são dentes humanos

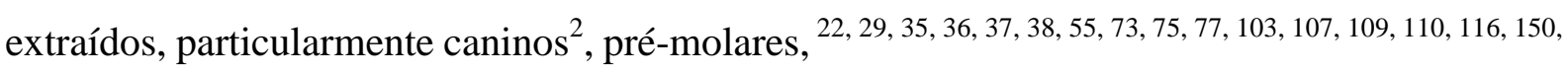
160, 162, 168, 170, 184, 185, 186, 199 e molares $3,33,34,42,46,48,49,50,58,64,68,71,78,82,93,94,103,119,124,141,148$, 154, 165, 169, 173, 175, 176, 180, 188, 190, 193, 200, 208. . A menor dificuldade em conseguir pré-molares extraídos por razões ortodônticas foi decisiva, na opção de escolha por esse dente. 
As característica e o tipo de cavidades testadas variam assim como os dentes, pois não há um consenso ou um protocolo padronizado para este tipo de avaliação. Assim é comum encontrar na literatura essas variações para dentes (posterior ou anterior) ou cavidades (classe V e II) amplas ou não. Alguns autores 3, 6, 19, 22, 29, 33, 35, 36, 37, 42, 49, 64, 65, 66, 68, 107, 104, 122, 136, 138, $141,145,148,154,161,165,180,185,188,190,193,190$, utilizaram cavidades de classe V e outros ${ }^{158}$ classe II tipo slot proximal e cavidades de classe II estritamente proximal ${ }^{50,82,94,160,173}$ A cavidade de classe II tipo M.O.D. selecionada para esta investigação foi a empregada pela maioria das pesquisas nessa área, apesar de algumas delas terem utilizado 34, 48, 58, 122, 154, 160, 169, 107, 176, 186. dois tipos de cavidades de classe II a estritamente proximal e a M.O.D..

Outra variação importante neste tipo de teste de infiltração diz respeito a localização do término cervical. Alguns autores empregam cavidades com a parede gengival em esmalte ou dentina/cemento. ${ }^{22,58,78,93,107,141,167, .169,176,180,186}$, enquanto outros utilizaram apenas cavidades com término cervical apenas em esmalte ${ }^{162,185,190}$. Por outro lado a grande maioria dos autores de pesquisas mais recentes, como neste trabalho, utilizaram cavidades com término cervical além da junção cemento-esmalte $29,33,46,48,49,66,68,82,188,193$.

Um outro fator que tem direcionado as pesquisas atuais relaciona-se com a inerente contração de polimerização das resinas compostas e os fenômenos nela envolvidos (tipo de resina foto ou quimicamente ativada, fator relacionando a configuração cavitária, coeficiente de expansão térmica, intensidade de luz do aparelho, distância do foco de luz, técnica de inserção. Estes fatores podem conduzir a fendas "gaps" as interfaces e consequentemente infiltração marginal. Em razão disso, várias pesquisas ${ }^{58,}$ 93, 94, 141, 148, 167, 180, 190 propuseram observar a utilização de mais de um tipo de material restaurador, ou seja, técnicas restauradoras mistas ou associadas conhecidas como "sanduíche". Devido a esse fator 
utilizou-se nesta pesquisa este tipo de técnica restauradora como descrito em 1993 por DAVIDSON, C.L.; ABDALLA, A.I. ${ }^{41}$.

Os materiais estéticos foram e continuam sendo amplamente testados em restaurações diretas ${ }^{19,103}$, especificamente as resinas compostas químicas ou fotopolimerizaveis conforme atestam as dezenas ou até centenas de estudos encontrados na literatura especializada 3, 6, 19, 22, $33,34,36,46,48,50,58,62,65,68,78,80,82,93,94,99,103,119,104,124,136,145,167,173,175,180,185,186,188,190,193,200$, ${ }^{208}$.Convém salientar que alguns desses trabalhos avaliaram comparativamente a contração de polimerização entre a resina composta fotopolimerizada e a ativada quimicamente $46,78,80,103$, 175 .

Outro aspecto que alguns autores ${ }^{68,119}$ verificaram e relataram foi o bom desempenho, quanto a infiltração marginal, das restaurações de resina composta associado a uma base de ionômero de vidro. Algumas informações importantes para o planejamento e formulação desta pesquisa foram obtidas de estudos que avaliaram materiais similares aos utilizados

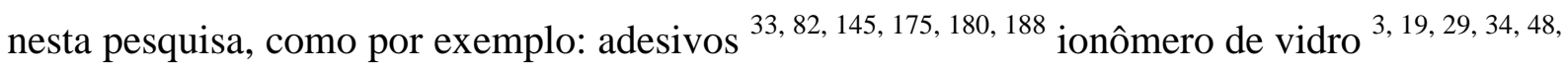
49, 50, 58, 93, 94, 145, 148, 168, 180, 190, 193 resina composta modificada por poliácidos ${ }^{69,71,158}$; ionômero modificado por resina $66,71,82,180,193$.

Algumas marcas comerciais de materiais restauradores utilizados nesta pesquisa foram também utilizados em testes “in vivo" e "in vitro”, como: adesivo dentinário ScotchbondMP (3M) 22, 46, 48, 58, 64, 65, 66, 68, 77, 94, 188, 190, 193. a resina composta Z-100 (3M) 22, 46, 66, 82, 124, 173, 190, 193, 208; concise (3M) ${ }^{6,62,161}$; Dyract-AP (Dentsply) ${ }^{110}$; Prime \& Bond 2.1 (Dentsply) ${ }^{109}$; Aeliteflo (Bisco) ${ }^{124}$; One step (Bisco) ${ }^{208,}$; Velvalloy (S.S. White) ${ }^{2}$ e vernizes cavitários de marcas variadas ${ }^{77}$. 
Vários fatores influenciam na longevidade das restaurações provocando a microinfiltração marginal $19,99,119,208$ tais como a contração de polimerização, coeficiente de expansão térmica, qualidade da camada híbrida, técnica de inserção, fator $\mathrm{C}$ das paredes cavitárias. Enquanto isso, outras variáveis ${ }^{19,39,165}$, como as propriedades mecânicas (módulo de elasticidade, resistência a tração, à compressão e ao cizalhamento) influenciaram na resistência á fratura e ao desgaste durante a vida clínica das restaurações confeccionadas pelo sistema restaurador adesivo.

ALANI; TOH ${ }^{1}$ em 1997, discutiram os principais métodos quantitativos e qualitativos para detectar e avaliar a microinfiltração ao redor das restaurações, como infiltração de corantes orgânicos, agentes traçadores químicos, traçadores radioativos, utilização de bactérias, pressão positiva pelo uso de ar comprimido, produção de cáries artificiais, análises em microscópio eletrônico de varredura, análise através de ativação de nêutrons e condução eletroquímica. Dessa maneira este estudo foi realizado com uma seqüência técnica coerente com alguns trabalhos $42,46,49,58,66,175$, e empregando o corante azul de Metileno com agente

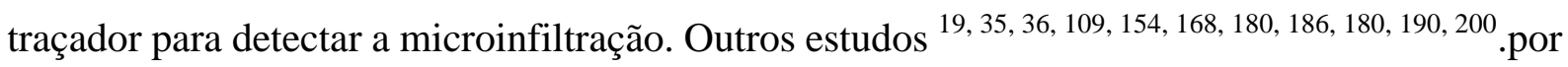
sua vez utilizaram como substância traçadora a fuccina básica, a Rhodamina B e ou Fluorceína sódica.

O mesmo problema de consenso a respeito do emprego da ciclagem térmica ocorrem com o teste de ciclagem mecânica no que se refere a carga, tempo e freqüência de cada ciclo. Alguns autores ${ }^{42,94,99,136,154}$ realizaram somente a ciclagem mecânica em seus testes, outros ${ }^{3,}$ $6,19,29,33,34,35,36,37,48,48,58,78,82,103,104,107,141,148,165,176,188,190,193$, realizaram somente a ciclagem térmica, enquanto outros ${ }^{119,137,145,173,186}$ associaram as duas metodologias. Ainda alguns autores 42, 75, 122, 160, 169 preconizaram essas ciclagens com o corpo de prova 
mergulhados no corante. Em função disso, e tendo em vista uma simulação de laboratório mais aproximada possível das condições clínicas, optou-se por submeter os corpos de prova (dente/restauração) desta pesquisa aos dois tipos de ciclagem imersos na solução traçadora.

Assim esta investigação baseou-se fundamentalmente no trabalho de RAADAL ${ }^{162}$ que em 1975 utilizou a ciclagem mecânica e ciclagem térmica em solução de azul de metileno. As temperaturas utilizadas na ciclagem térmica foram iguais a outros trabalhos $130,150,182,200$.

É muito grande a influência da termociclagem nos resultados de avaliação da microinfiltração conforme chamou a atenção ALANI; TOH ${ }^{1}$ em 1997 . De fato existe uma grande variação nos resultados obtidos pelos mais diferentes autores $3,29,33,34,35,36,37,46,48,49$, 82, 103, 104,107, 114, 141, 148, 176, 193 talvez devido às diferentes temperaturas utilizadas na ciclagem térmica, à duração de cada banho, número de ciclos e, em qual substância os corpos de prova foram ciclados, em algumas pesquisas $19,35,58,78,165,173,190$ as ciclagens térmicas foram realizadas com corante e até mesmo em saliva artificial ${ }^{6}$. Verificando-se que não existe um consenso a respeito destes fatores devido à diversidade de metodologia e resultados contraditórios . 


\section{2 - Condições experimentais}

Por meio da metodologia descrita para o desenvolvimento deste estudo, os espécimes referentes a cada condição experimental foram avaliados qualitativamente por exames microscópico, sendo o índice de penetração do corante na região cervical, estabelecido através da atribuição de escores, por dois examinadores, havendo concordância de aproximadamente $95 \%$ entre os mesmos.

Os valores (escores) individuais de penetração do corante, na interface cemento/material restaurador, atribuídos aos espécimes referente às cinco condições experimentais, encontram-se registrados na figura 5.2.1.

\begin{tabular}{|c|c|c|c|c|c|c|c|c|c|c|}
\hline & \multicolumn{2}{|c|}{ Grupo1 } & \multicolumn{2}{|c|}{ Grupo 2} & \multicolumn{2}{|c|}{ Grupo 3} & \multicolumn{2}{|c|}{ Grupo 4} & \multicolumn{2}{|c|}{ Grupo 5} \\
\hline $\begin{array}{l}1 \\
2 \\
3 \\
4 \\
5 \\
6 \\
7 \\
8 \\
9 \\
10\end{array}$ & $\begin{array}{l}\text { Concise } \\
\text { Z-100 } \\
1 \\
2 \\
1 \\
2 \\
1 \\
2 \\
1 \\
2 \\
1 \\
1\end{array}$ & $\begin{array}{l}\text { Z-100 } \\
\text { controle } \\
2 \\
2 \\
2 \\
3 \\
2 \\
2 \\
2 \\
2 \\
2 \\
2\end{array}$ & $\begin{array}{l}\text { Natural flow } \\
+Z-100 \\
2 \\
1 \\
2 \\
2 \\
1 \\
1 \\
2 \\
1 \\
2 \\
2\end{array}$ & $\begin{array}{l}\text { Z-100 } \\
\text { controle } \\
2 \\
2 \\
2 \\
2 \\
2 \\
2 \\
2 \\
2 \\
3 \\
3\end{array}$ & $\begin{array}{l}\text { Aeliteflo }+ \text { Z- } \\
100 \\
1 \\
2 \\
2 \\
1 \\
1 \\
2 \\
1 \\
1 \\
2\end{array}$ & $\begin{array}{l}\mathrm{Z}-100 \\
\text { controle } \\
2 \\
3 \\
2 \\
2 \\
2 \\
2 \\
2 \\
2 \\
2 \\
2\end{array}$ & $\begin{array}{l}\text { Dyract } \\
\text { Z-100 } \\
0 \\
1 \\
1 \\
0 \\
1 \\
1 \\
1 \\
0 \\
1 \\
0\end{array}$ & $\begin{array}{l}\text { Z-100 } \\
\text { controle } \\
2 \\
2 \\
2 \\
2 \\
2 \\
3 \\
2 \\
2 \\
2 \\
2\end{array}$ & $\begin{array}{l}\text { Velvalloy } \\
+Z-100 \\
3 \\
3 \\
3 \\
2 \\
2 \\
3 \\
3 \\
3 \\
3 \\
3\end{array}$ & $\begin{array}{l}\text { Z-100 } \\
\text { controle } \\
3 \\
3 \\
2 \\
2 \\
2 \\
2 \\
2 \\
2 \\
2 \\
3\end{array}$ \\
\hline
\end{tabular}

FIGURA 5.2.1 - Quadro dos valores individuais (escores) do índice de penetração do corante na interface cemento/material restaurador para as duas condições (controle e experimental) dentro de cada um dos cincos grupos. 
$\mathrm{Na}$ figura 5.2.2., encontra-se registrados o número e a porcentagem de espécimes nos quais não ocorreram penetração do corante nas interface cemento/material restauradores e, que receberam escores zero, correspondentes aos materiais específicos, que foram aplicados em uma das paredes gengivais das restaurações M.O.D. associadas ao Z-100 (condição experimental)

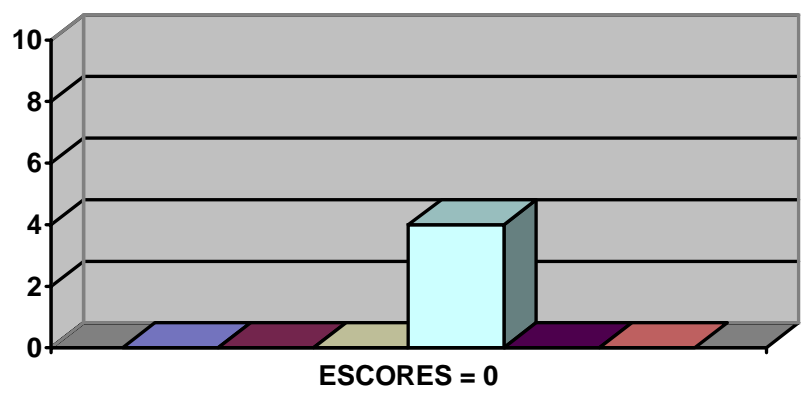

\begin{tabular}{|l|}
$\square 0 \%-$ CONCISE + Z100 \\
$\square 0 \%-$ NATURAL FLOW + Z100 \\
$\square 0 \%$ - AELIT FLO + Z100 \\
$\square 40 \%$ - DYRACT-AP + Z100 \\
$\square 0 \%$ - VELVALLOY + Z100 \\
$\square 0 \%$ - CONTROLES
\end{tabular}

FIGURA 5.2.2 - Gráfico representativo dos números e porcentagem de espécimes livres de infiltração do corante na região cervical, aonde esses materiais específicos foram associados à resina Z 100 (condição experimental) ou não (condição controle)

Pode-se observar que os espécimes relativos ao grupo 4 (Dyract-AP) apresentou, de maneira geral, maior \% de escores zero, correspondendo a um índice menor de penetração do corante na região cervical, enquanto os valores em números e/ou \% de escores maiores que zero foram encontrados na maioria dos grupos 1,2,3 e 5 e nos controles (Concise, Natural flow, Aeliteflo, Velvalloy e Z-100-controles) são indicativos de uma maior magnitude de infiltração.

Uma análise geral dos valores em escores demonstra haver diferença aritmética entre as médias obtidas para os diferentes grupos estudados, tanto na condição experimental (figura 5.2.3) quanto para a condição controle (figura 5.2.4). Assim, com a finalidade de determinar 
se as diferenças aritméticas observadas eram estatisticamente significante, os valores obtidos foram submetidos ao tratamento estatístico. Através do teste não paramétrico de KruskalWallis, foi detectada diferença estatisticamente significante ao nível de $1 \%(\mathrm{p} \leq 0,001)$ entre os grupos experimentais, com relação à infiltração ocorrida na interface cemento/material restaurador da condição experimental quanto na interface cemento/material na condição controle, onde se empregou apenas a resina Z-100 não se detectou diferença estatística.

\begin{tabular}{|l|l|l|l|l|l|}
\hline \multicolumn{2}{|c|}{ Concise + Z-100 } & Natural flow + Z-100 & Aeliteflo + Z-100 & Dyract + Z-100 & Velvalloy + Z-100 \\
\hline Mediana & $\mathbf{1}$ & $\mathbf{2}$ & $\mathbf{1 , 5}$ & $\mathbf{1}$ & $\mathbf{3}$ \\
D.P. & $\mathbf{0 , 5 1 6}$ & $\mathbf{0 , 5 1 6}$ & $\mathbf{0 , 5 2 7}$ & $\mathbf{0 , 5 1 6}$ & $\mathbf{0 , 4 2 2}$ \\
Média & $\mathbf{1 , 4}$ & $\mathbf{1 , 6}$ & $\mathbf{1 , 5}$ & $\mathbf{0 , 6}$ & $\mathbf{2 , 8}$ \\
\hline
\end{tabular}

FIGURA 5.2.3 - Quadro demonstrativo da Mediana e Média do teste de Kruskall-Wallis relativos à infiltração marginal na interface cemento/material restaurador, do grupo ou condição experimental das restaurações.

\begin{tabular}{|c|c|c|c|c|c|}
\hline & Z-100/GRUPO 1 & Z-100 / GRUPO 2 & Z-100 / GRUPO 3 & Z-100/ GRUPO 4 & Z-100 / GRUPO 5 \\
\hline \begin{tabular}{|l} 
Mediana \\
D.P. \\
Média
\end{tabular} & $\begin{array}{l}2 \\
0,316 \\
2,1\end{array}$ & $\begin{array}{l}2 \\
0,422\end{array}$ & \begin{tabular}{|l|}
2 \\
0,316 \\
2,1
\end{tabular} & \begin{tabular}{|l|}
2 \\
0,316 \\
2,1
\end{tabular} & \begin{tabular}{|l|}
2 \\
0,483 \\
2,3
\end{tabular} \\
\hline
\end{tabular}

FIGURA 5.2.4 - Quadro demonstrativo da Mediana e Média do teste de Kruskall-Wallis relativos à infiltração marginal na interface cemento/material restaurador Z-100 respectivo para cada condição controle das restaurações.

Para uma comparação entre os materiais e outra comparação entre as condições controles o teste de Kruskall-Wallis foi realizado. 


\begin{tabular}{|l|l|l|}
\hline Comparação & H & P \\
\hline Entre materiais & $\mathbf{3 1 , 6 1}$ & $<\mathbf{0 , 0 0 1} *$ \\
Entre - Controles - Z 100 & $\mathbf{2 , 3 3}$ & $\mathbf{0 , 6 7 5} \mathbf{~ n s}$ \\
\hline
\end{tabular}

* - Diferença estatisticamente significante $(\alpha<5 \%)$

ns - Diferença estatística não significante $(\mathrm{p}<0,05)$

FIGURA 5.2.5 - Quadro demonstrativo do Teste de Kruskall-Wallis para comparação entre os materiais experimentais.

Para a comparação entre os materiais testados avaliados por escores e pareados e seus respectivo controles foi então realizado o teste de Wilcoxon (figura 5.2.6)

\begin{tabular}{|l|c|l|}
\hline Material & $\mathbf{W}$ & $\mathbf{P}$ \\
\hline Concise & $\mathbf{2 8}$ & $\mathbf{0 , 0 1 6} *$ \\
Velvalloy & $\mathbf{- 1 5}$ & $\mathbf{0 , 0 6 3} \mathbf{~ n s}$ \\
Dyract & $\mathbf{5 5}$ & $\mathbf{0 , 0 0 2} *$ \\
Natural flow & $\mathbf{2 1}$ & $\mathbf{0 , 0 3 1} *$ \\
Aeliteflo & $\mathbf{2 1}$ & $\mathbf{0 , 0 3 1}$ \\
\hline \multicolumn{2}{|c|}{ * - Diferença estatisticamente significante $(\alpha<5 \%)$} \\
N.S. - Diferença estatística não significante $(\mathrm{p}<0,05)$
\end{tabular}

FIGURA 5.2.6 - Quadro demonstrativo do Teste de Wilcoxon utilizando para comparação de 2 grupos avaliados por escores e pareados para comparação entre materiais testados e seus respectivos controles (Z-100) 
Com a finalidade de facilitar a comparação entre os diversos grupos estudados, as médias referente aos escores alcançados para cada condição experimental foram transportadas para gráficos de barras (figuras 5.2.7 e 5.2.8)

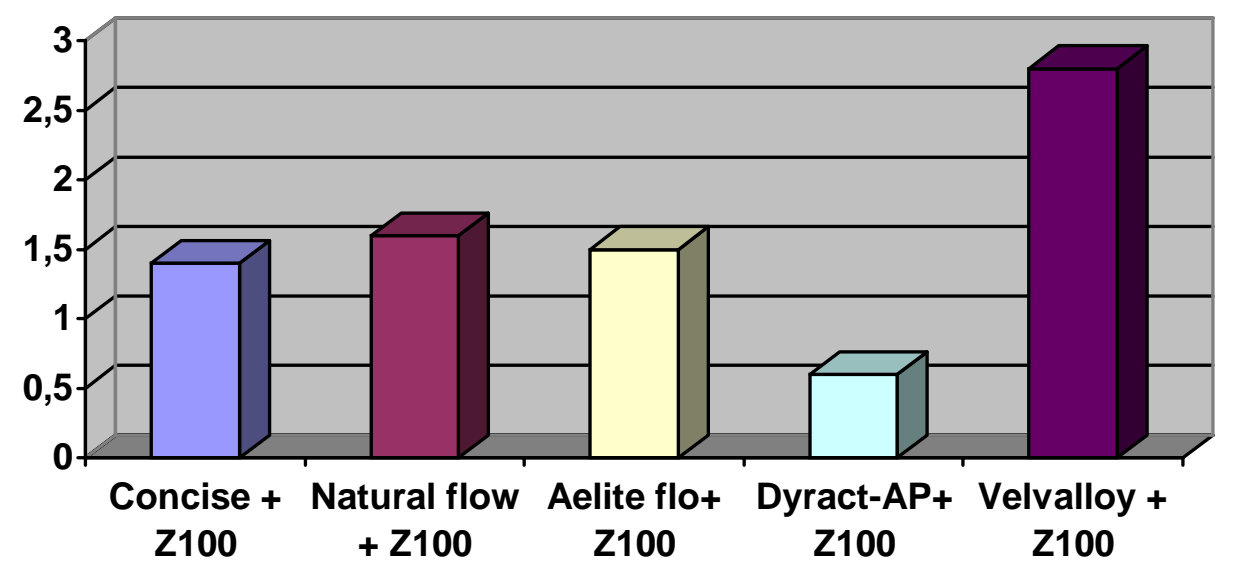

FIGURA 5.2.7 - Gráfico comparativo dos escores médios obtidos nos testes de avaliação da infiltração na interface cemento/material restaurador na condição experimental.

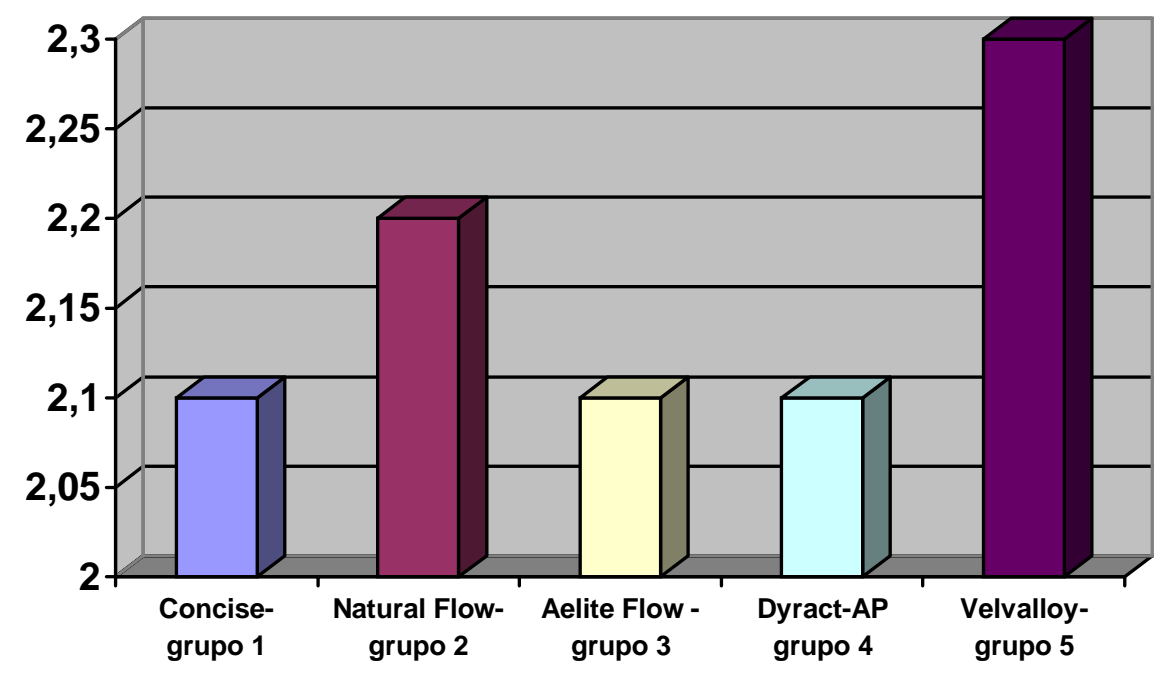

FIGURA 5.2.8 - Gráfico comparativo dos escores médios obtidos nos testes de avaliação da infiltração na interface cemento/material restaurador Z-100 referente a cada condição controle. 
Para que as comparações individuais entre os grupos pudessem ser analisadas, foi aplicado o teste pelo método de Student-Newman-Keuls (figura 5.2.9).

\begin{tabular}{|l|c|c|c|}
\hline \multicolumn{1}{|c}{ GRUPOS } & DIFERENÇA ENTRE POSTOS & P $\leq \mathbf{0 , 0 5}$ \\
\hline Velvalloy Vs. Dyract-AP & $\mathbf{3 4 0 , 0}$ & $\mathbf{7 , 3 7 6}$ & $*$ \\
Velvalloy Vs. Concise & $\mathbf{2 1 4 , 0}$ & $\mathbf{5 , 7 8 9}$ & $*$ \\
Velvalloy Vs. Aeliteflo & $\mathbf{1 9 5 , 0}$ & $\mathbf{7 , 0 0 5}$ & $*$ \\
Velvalloy Vs. Natural flow & $\mathbf{1 7 6 , 0}$ & $\mathbf{9 , 4 0 8}$ & $*$ \\
Natural flow Vs. Dyract-AP & $\mathbf{1 6 4 , 0}$ & $\mathbf{4 , 4 3 6}$ & $*$ \\
Natural flow Vs. Concise & $\mathbf{3 8 , 0}$ & $\mathbf{1 , 3 6 5}$ & N.S. \\
Natural flow Vs. Aeliteflo & $\mathbf{1 9 , 0}$ & $\mathbf{1 , 0 1 6}$ & N.S. \\
Aeliteflo Vs. Dyract-AP & $\mathbf{1 4 5 , 0}$ & $\mathbf{5 , 2 0 9}$ & $*$ \\
Aeliteflo Vs. Concise & $\mathbf{1 9 , 0}$ & $\mathbf{1 , 0 1 6}$ & N.S. \\
Concise Vs. Dyract-AP & $\mathbf{1 2 6 , 0}$ & $\mathbf{6 , 7 3 5}$ & $*$ \\
\hline
\end{tabular}

* Diferença estatisticamente significante $(\mathrm{P} \leq 0,05)$.

N.S. - Diferença estatisticamente não significante.

FIGURA 5.2.9 - Quadro demonstrativo do Teste de Student-Newman-keuls, aplicado na avaliação da infiltração na interface cemento/material experimental.

\section{3 - Condição controle: Z-100}

A não ocorrência de significância estatística da condição controle (figura 5.2.5) onde 100 segmentos próximais foram restaurados com Z-100, indica que os ensaios foram bem realizados, controlados e protegidos de valores discrepantes.

Não existiu preocupação nesta investigação em avaliar a penetração do corante na interface entre os materiais dos grupos experimentais onde um dos segmentos próximais foi restaurado com resina 
composta Z-100 associada a um segundo material restaurador. Os resultados obtidos por $\mathrm{BOTELHO}^{17}$, em recente trabalho realizado no laboratório de pesquisa da disciplina de Dentística da FOB-USP, eliminou a necessidade dessa verificação. Esta investigação indicou um índice de infiltração severo apenas nas interfaces resinas Z100/Velvalloy, ocorrendo isenção de infiltração em $99 \%$ dos espécimes com interfaces da resina Z-100 com resinas ativadas quimicamente, ionômero de vidro e compômeros.

Já era de se esperar um resultado desfavorável relacionado ao grupo ou condição controle em função da aplicação da resina composta na parede gengival sem margem de esmalte, mesmo lançando-se mão de um adesivo dentinário de última geração, uma vez que estes materiais não apresentam boa capacidade de união com o cemento. Aproximadamente $90 \%$ dos espécimes deste grupo apresentaram escore 2, como caracterizado na figura 5.3.1. 


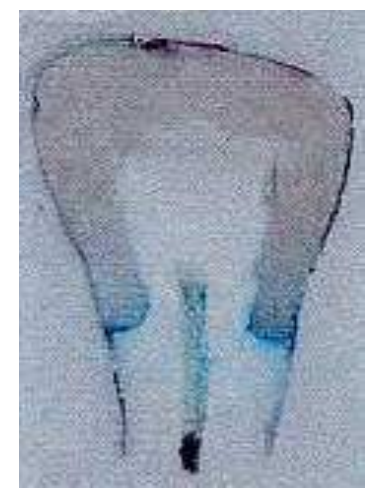

FIGURA 5.3.1 - Ilustração fotográfica característica da microinfiltração cervical severa atingindo a parede axial do lado esquerdo (Z-100), escore 2 e, do lado direito (Natural Flow), escore 3 , resultante na condição ou grupo controle, cujas cavidades foram restauradas com a resina composta Z-100.

Os resultados obtidos vem de encontro aos achados de MARTIN; BRYANT $^{18}$ e PEREIRA ${ }^{153}$, ao observarem que a margem cervical de uma restauração é o local onde aparecem as maiores falhas devido à direção longitudinal dos prismas e à fina camada de esmalte. Portanto, o problema se agrava quando inexiste esmalte nessa região. Por esse motivo, optou-se no presente estudo pela avaliação da infiltração marginal na parede gengival localizada em cemento e/ou dentina, por ser comum uma situação clínica onde a remoção do tecido cariado ou de uma restauração preexistente resulte em uma parede gengival situada abaixo da junção amelocementária. Estudos recentemente realizados na disciplina de Dentística da FOB $\left(\right.$ BOTELHO $^{17}$; E PEREIRA $^{153}$ ) tem demonstrado ser uma área crítica, particularmente mais propensa à infiltração marginal. 
Talvez o mal comportamento apresentado pelos espécimes do grupo controle esteja associado à complexidade de composição e heterogeneidade do substrato dentinário e/ou cementário, assim como à distribuição de suas estruturas, o que desfavorece a adesão da resina composta na região cervical, permanecendo este fator um sério problema para os cirurgiões dentistas, enquanto o esmalte apresenta-se como uma estrutura naturalmente mais homogênea, o que possibilita uma melhor qualidade adesiva.

Apesar do grande desenvolvimento das resinas compostas, estas permanecem ainda com algumas deficiências, principalmente o fato de não haver uma união perfeita com as paredes cavitárias e o seu hermético selamento. Em conseqüência disto, podem ser observados microespaços ou microfendas "gaps" através dos quais ocorre o processo de microinfiltração.

A introdução da técnica do condicionamento ácido do esmalte, proposta por BUONOCORE ${ }^{20}$, a qual, promove o aumento da área de superfície e a capacidade de umectação permitindo um contato mais íntimo entre a resina restauradora e o esmalte dental, melhorou sensivelmente a retenção a este substrato e reduziu substancialmente a infiltração marginal. Por outro lado, a perfeita união dos adesivos à dentina e/ou cemento continua sendo um desafio para os pesquisadores. Caso uma adesão micromecânica similar à atingida entre a resina composta e o esmalte condicionado fosse alcançada em todos os tipos de restaurações de resina, ter-se-ia um resultado efetivo quanto à adaptação e microinfiltração marginal. 
Trabalhos de avaliação clínica também comprovam os resultados aqui obtidos, os quais apresentaram-se pouco promissores já que a adesão à dentina é um processo físico-químico complexo ${ }^{4}$. A dentina é constituída por substâncias orgânicas e inorgânicas onde $55 \%$ de sua estrutura são compostos por minerais (cristais de apatita envolvidos em uma matriz de colágeno, 30\% por substâncias inorgânicas e $15 \%$ por líquido; assim, para se conseguir uma adesão a esse substrato é necessário que aconteça um embricamento dos agentes resinosos aos seus componentes orgânicos e/ou inorgânicos. A superfície dentinária apresenta natureza hidrofílica, com baixa energia de superfície, além de apresentar a smear layer e o exsudado protéico após a confecção da cavidade. Por essa razão, os sistemas adesivos foram aperfeiçoados, com a finalidade de contornar algumas das limitações das resinas compostas utilizadas como material restaurador, proporcionando um melhor vedamento marginal.

RETIEF $^{164}$ definiu o fenômeno de adesão como o estado no qual duas superfícies se mantêm unidas por forças interfaciais, podendo-se consistir em forças química e mecânica ou ambas. O adesivo é definido como a substância capaz de manter juntos os materiais por meio de uma superfície de fixação. De acordo com EIDELMAN et.al. ${ }^{56}$, o uso de um agente dentinário não diminui a microinfiltração na região de cemento quando a cavidade é totalmente restaurada com resina composta.

Presume-se que para eliminar a infiltração na interface cervical em dentina e/ou cemento seria imprescindível a existência de uma união química entre o material e a estrutura dentária para que se pudesse aproximar 
de um selamento perfeito. Por outro lado, é conhecido que a união entre as restaurações de resina às paredes cavitárias é um processo unicamente de natureza mecânica, o que aumenta a preocupação dos pesquisadores e fabricantes no sentido de eliminar o problema.

A preocupação em se conseguir adesão à estrutura dentária e diminuir o índice de infiltração marginal nas restaurações de resina restauradoras em cavidades com paredes situadas em dentina e/ou cemento data de $1956^{182}$, quando foi desenvolvido um primer ou adesivo dentinário à base de dimetacrilato-ácido-glicerofosfórico (Cavit-Seal) que era usado com as resinas acrílicas, sem entretanto obter sucesso. A partir daí, outros produtos similares foram desenvolvidos e comercializados, não correspondendo às expectativas clínicas. Durante estes últimos 20 anos, vários sistemas adesivos e métodos de aplicação foram desenvolvidos, pesquisados e introduzidos no mercado.

Atualmente, novos conceitos e procedimentos restauradores adesivos vem sendo implantados, modificando a filosofia de tratamento e ampliando as alternativas clínicas. Um dos grandes desafios da Odontologia Restauradora refere-se aos sistemas adesivos dentinários, pois mesmo com toda a evolução por eles experimentada ainda não se conseguiu para a dentina e cemento, como confirmado neste trabalho, um resultado tão eficaz quanto a união ao esmalte.

A técnica do condicionamento ácido total está indicada em cavidades que apresentam áreas esclerosadas ou suficiente estrutura remanescente de dentina no fundo da cavidade, pois, uma espessura de 0,5 
$\mathrm{mm}$ e $1 \mathrm{~mm}$ de dentina remanescente pode reduzir a toxidade dos materiais restauradores em até $75 \%$ e $90 \%$ respectivamente ${ }^{95,135}$. MONDELLI et al ${ }^{135}$. e HOVAV et al. ${ }^{95}$ esclareceram que, caso o complexo dentinopulpar venha a remineralizar a dentina condicionada em contato com o adesivo (camada híbrida), esta camada poderá tornar-se tão forte quanto uma dentina normal e não ser uma zona de desunião, como visto in vitro por NAKABAYASHI; NAKAMURA; YASUDA ${ }^{143}$. Contudo, a atuação de um adesivo dentinário tem sido um problema de difícil solução e permanece um campo aberto para a pesquisa, pois, somente recentemente se teve um real progresso a este respeito.

Evoluindo o raciocínio a respeito do extremo índice de infiltração relacionado ao uso de resinas compostas, uma outra explicação considerada bastante razoável para justificar a sua ocorrência, principalmente em regiões onde inexiste esmalte marginal, como é o caso do presente estudo, seriam os altos valores de contração sofrida por estes materiais durante sua polimerização. Este mesmo raciocínio é confirmado por PRATI et al. ${ }^{160} \mathrm{e}$ PERDIGÃO et al. ${ }^{152}$, ao alegarem que a infiltração marginal em cavidades de classe II com margens localizadas em cemento é conseqüência principalmente das mudanças dimensionais experimentadas pela resina composta. Assim sendo, a contração de polimerização sofrida por este materiais é a grande responsável pela infiltração marginal nas restaurações adesivas diretas, consistindo em uma de suas principais desvantagens, a qual poderá resultar em discrepâncias marginais, direcionando para o manchamento, 
microinfiltração marginal, sensibilidade pós-operatória e ocasionalmente o desenvolvimento de cáries secundárias.

Considerando que a contração de polimerização das resinas compostas fotoativadas deve ser controlada pelo operador afim de diminuir a severidade da infiltração marginal, muitos autores 118,119 recomendam a inserção das resinas compostas pela técnica incremental, em que pequenas porções são inseridas na cavidade e em seguida polimerizadas, conseguindose desta maneira que a contração sofrida pela porção anterior seja parcialmente compensada pela adição da porção posterior.

LUTZ et al. ${ }^{118}$ alegam que o grande problema relacionado com a formação de fendas marginais decorrentes da contração de polimerização do adesivo e da resina composta, quando aplicados na região cervical, foi minimizado com o emprego de cunhas inter-proximais reflectivas, matrizes transparentes e técnicas de aplicação incremental das resinas na caixa proximal. Com estes artifícios técnicos, consegue-se o direcionamento do vetor de contração de polimerização das resinas compostas em direção às paredes cavitárias, diminuindo consideravelmente a formação de fendas, deflexão das cúspides e conseqüentes infiltração marginal, sensibilidade pósoperatória e recidiva de cáries. Dessa maneira, baseados nas novas formas de cunhas reflectivas e com o uso de bases de cimento de ionômero de vidro, LUTZ et al. ${ }^{119}$ desenvolveram uma técnica de inserção em 3 incrementos, tendo sido a mesma aplicada neste trabalho, exatamente como exposto na descrição da metodologia. Com o emprego desta técnica, os vetores de 
contração de polimerização parecem ter sido consistentemente direcionados para as margens cavitárias durante a reação de cura.

Por outro lado, LÖSCHE ${ }^{115}$ não observou diferença estatística significante quanto à adaptação marginal, para as técnicas de polimerização oclusal ou direcionada quando da utilização para ambas, de iguais níveis de energia. O autor ${ }^{115}$ concluiu que o efeito resultante da técnica de inserção incremental não deve ser atribuído ao direcionamento dos vetores de contração e sim à redução da intensidade inicial de luz (soft-start) em função da incidência transdental ou seja, através das paredes cavitárias. Comparadas às resinas de ativação química nas fotoativadas ocorre uma rápida reação de polimerização, a qual se torna ainda mais acelerada pelo emprego de alta intensidade de luz, desejável para a ótima polimerização, restringindo portanto o escoamento do material e consequentemente o alívio dos estresses gerados ${ }^{87,115}$. Assim sendo, LÖSCHE ${ }^{115}$ recomenda que a intensidade inicial de luz seja reduzida pela polimerização dos incrementos de resina através das paredes cavitárias como sugerido por LUTZ et al. ${ }^{119}$ prolongando desta maneira a fase de escoamento do material, e para assegurar uma adequada reação de polimerização, torna-se necessário a incidência adicional de luz por oclusal pois, a espessura da estrutura dentária associada ao uso de matrizes e o rápido aumento da opacidade do esmalte causado por sua desidratação, são fatores clínicos importantes que juntos resultam em valores baixos, para assegurar completa polimerização. O emprego desta técnica segundo LÖSCHE 115 e DIETRICH et al. ${ }^{47}$, resulta em baixas forças de contração durante a 
polimerização, redução da infiltração na interface das restaurações e melhor adaptação marginal.

VERSULUIS ${ }^{196}$, por sua vez, relata que o processo de polimerização pode ser caracterizado pelas fases pré-gel e pós-gel e, o estresse desenvolvido na restauração durante a reação de polimerização pode ser rapidamente aliviado ainda na fase pré-gel, pelo escoamento do material. Nas resinas fotopolimerizáveis, o ponto gel varia no corpo da restauração, em função da intensidade de luz ${ }^{196}$. VERSULUIS ${ }^{196}$ alega que a direção da contração não é significantemente afetada pela orientação da luz e sim determinada em grande maioria pelas condições da adesão da restauração à estrutura dentária e pelas superfícies livres existentes, consequentemente, serão mínimas as diferenças entre os padrões da reação química e fotopolimerização. Este pesquisador ${ }^{196}$ acredita, que as resinas compostas não contraem em direção à luz, mas que a direção da contração é predominantemente determinada pela configuração cavitária e qualidade adesiva e, portanto, a direção dos vetores em resposta ao posicionamento da luz, não parece ser um critério apropriado para favorecer a qualidade marginal de uma restauração.

A contração de polimerização das resinas compostas é avaliada segundo BAUSCH et al. ${ }^{9}$ entre $2 \%$ a $3 \%$ em volume, o que as torna incompatíveis com a resistência de união adesiva das paredes cavitárias de dentes posteriores ${ }^{119}$. Enquanto as resinas compostas não apresentarem diminuição nos valores de contração volumétrica e das tensões de contração, será necessário que os profissionais superem este inconveniente, lançando mão de procedimentos 
técnicos que propiciem uma melhor adaptação do material restaurador às paredes cavitárias.

Dependendo do volume de resina, do número de superfícies aderidas e livres e do posicionamento da fonte polimerizadora, esta contração pode gerar tensões que ultrapassam a capacidade de união do sistema adesivo, provocando ruptura e formando a fenda marginal durante a execução da restauração ${ }^{16,35,43,108,119}$.

De acordo com DAVIDSON et al. ${ }^{42}$ e FEILZER et al. ${ }^{61}$ a força ou tensão gerada pela contração de polimerização poder ser relatado em torno de 13 a 17 Mpa, sendo maior que a força de adesão de muitos adesivos dentinários. Assim sendo, RETIEF et al. ${ }^{164}$ correlacionaram dados obtidos em testes de resistência ao cisalhamento e de microinfiltração, cujos resultados sugeriram que uma resistência adesiva ao cisalhamento de aproximadamente 21 Mpa poderia reduzir a infiltração marginal a zero.

A maioria dos sistemas adesivos dentinários não conseguem prevenir efetivamente a formação de gaps pela força de contração, na margem gengival, por causa de sua resistência adesiva ser relativamente fraca ${ }^{190}$. Talvez fosse mais correto afirmar que, nenhum sistema adesivo dentinário atualmente conhecido seja capaz de prevenir esses fatores inconvenientes.

A contração de polimerização $5,8,16,20,119$, o coeficiente de expansão térmica linear 19,24, 51,103,171 e o módulo de elasticidade, diferentes daqueles da estrutura dentária, são algumas características das resinas compostas que desempenham um papel importante na microinfiltração marginal. Pode-se considerar, portanto, a força de contração de polimerização 
das resinas compostas como um fator de partida explicar e o precário vedamento marginal destas restaurações em se tratando de estrutura dentinária ou cementária.

\section{4 - Condição 1: Concise/Z-100}

Uma outra alternativa considerada na proposição desta pesquisa, na tentativa de assegurar melhor adesão às paredes cavitárias e de controlar a microinfiltração marginal em restaurações estéticas de classe II, consiste na utilização de uma resina composta quimicamente ativada, para restaurar o terço cervical das caixas proximais, com término em cemento.

Resina composta híbrida concise ativada quimicamente foi o material selecionado para esta finalidade, o qual, segundo BERTOLOTTI ${ }^{13}$ e FUSAYAMA $^{72}$ tem como objetivo minimizar a microinfiltração nesta região, coadjuvando desta forma o sucesso das restaurações posteriores de resina composta pela técnica do "sanduíche".

Baseando-se na possibilidade de ser a resina química coadjuvante das resinas fotopolimerizáveis na redução da infiltração marginal nas restaurações estéticas de classe II, este procedimento restaurador foi incluído na proposição do presente estudo, correspondendo ao grupo 1 (Concise/Z-100). Os resultados obtidos vieram confirmar que a resina composta quimicamente ativada foi menos suscetível à penetração do corante nas margens das restaurações, quando comparada com a resina composta fotopolimerizável (condição controle - figura 5.4.1). 
Este grupo experimental ocupa uma posição intermediária, a semelhança do grupo 2 (natural Flow + Z-100) e grupo 3 (Aeliteflo+ Z-100), apresentando resultado estatisticamente diferente do grupo 5 (figura5.2.5) e do grupo controle (figura5.2.6). Desse modo, essa condição experimental apresentou índice de infiltração marginal inferior ao observado para a condição Velwaloy/Z-100 igual ao grupo 2 e o grupo 3, mas inferior estatisticamente ao grupo 4 (Dyract/Z-100).

Já é de conhecimento que as resinas compostas, ao serem inseridas no interior de cavidades preparadas, conduz a uma competição entre as forças de contração de polimerização e a resistência de união à estrutura dentária. A contração resultante da polimerização da resina composta cria forças que podem romper a união com as paredes cavitárias. Assim sendo, essa competição entre o estresse mecânico na polimerização e a união das resinas às paredes da cavidade representa uma das principais causas que acarreta em falhas e subsequientemente em microinfiltrações. A microinfiltração, sendo responsável pela indução de cárie secundária, é a principal razão para a substituição de restaurações com resina composta. Caso uma pequena fração de união for quebrada durante a contração de polimerização, a retenção da resina pode não ser significantemente afetada, contudo, o selamento da restauração será comprometido e poderá ocasionar sérios problemas. Em se tratando de cavidades de classe II, a adaptação do material às paredes cavitárias torna-se ainda mais críticas, porque a quantidade de resina utilizada é maior e o acesso para a polimerização por luz é dificultado, pois, uma vez que a superfície oclusal, mais próxima ä fonte de luz, polimeriza primeiro, os vetores de contração são dirigidos para essa região, provocando o afastamento da resina da parede cervical.

BERTOLOTTI ${ }^{13}$, em 1991, também considerando ser a contração de polimerização das resinas compostas um fator limitante para a sua utilização, principalmente em se tratando 
de cavidades de classe II, empregou a técnica direcionada como uma solução para minimizar o estresse gerado por esta contração, induzindo desta forma a contração de polimerização mais em direção às paredes cavitárias do que em direção ao centro da massa material. Embora exista na literatura uma série de trabalhos, como o de LAMBRECHTS et al. ${ }^{108}$ confirmando que a fotopolimerização se inicia na superfície e depois se irradia através de todo o material, enquanto na polimerização química a reação acontece ao mesmo tempo em todo o material e a contração orienta-se para o centro da massa, afastando o material igualmente de todas as paredes cavitárias, para BERTOLOTTI ${ }^{13}$ e FUSAYAMA ${ }^{72}$ a polimerização das resinas compostas fotoativadas ocorrem inicialmente na superfície oclusal da restauração, havendo tendência do material separar-se inicialmente das margens cavitárias, polimerizando-se seqüencialmente em direção ao centro da restauração. Contraditoriamente a este comportamento, as resinas quimicamente ativadas polimerizam-se inicialmente nas áreas mais profundas, uma vez que a polimerização é acelerada pela temperatura do corpo e inibida pela presença de oxigênio. Desta forma, nas áreas cavitárias mais profundas, há maior aquecimento e o mínimo de exposição ao ar. Com o progresso da polimerização, o material passa a ser atraído para a periferia. Pelo Exposto, BERTOLOTTI ${ }^{13}$ sugeriu para restaurações de classe II o emprego de uma resina química na restauração do terço cervical das caixas proximais, após a realização do condicionamento ácido total e aplicação do sistema adesivo, e recomenda, antes de sua completa polimerização, preencher o restante da cavidade com uma resina fotopolimerizável, resultando assim no direcionamento da contração junto às paredes cavitárias, o que favorecerá a adaptação marginal. Esta técnica combina as vantagens da resina composta quimicamente ativada ser inserida na região interna da cavidade com as vantagens oferecidas pelas resinas fotoativadas quando aplicadas na região mais externa: 
maior resistência ao desgaste, maior estabilidade de cor, maior dureza, além de permitir o prolongamento do tempo de trabalho.

Segundo FEILZER et al. ${ }^{61}$, tem sido demonstrado que as resinas fotopolimerizáveis geram maiores estresses durante a contração de polimerização que as análogas resinas químicas, e essa contração interfere progressivamente na adesão do material às paredes cavitárias.

As resinas fotoativadas, por serem submetidas à rápida e imediata reação de polimerização, permitem um menor escoamento, pois durante esta reação não existe um estágio gel por muito tempo. SAKAGUCHI et al. ${ }^{177}$ explicaram que a resina composta é capaz de escoar durante a fase pré-gel e aliviar o estresse interno, contudo, na fase de endurecimento do material, o escoamento é limitado e incapaz de compensar as forças de contração. Portanto, a polimerização pós-gel tem significância clínica na união resina/dente, podendo causar falhas de união e conseqüente microinfiltração marginal. Quanto menor a capacidade de escoar, maior será o estresse de contração de polimerização, o qual pode ser decisivo para o sucesso dos procedimentos adesivos.

Autores como KEMP-SCHOLTE; DAVIDSON ${ }^{102}$ observaram uma relação inversamente proporcional entre a qualidade da margem e o módulo de elasticidade da resina composta, ou seja, um maior módulo de elasticidade implica em margens inadequadas. Observaram, portanto, que as resinas compostas quimicamente ativadas obtiveram melhor adaptação marginal quando comparadas com as resinas fotopolimerizáveis, resultado atribuído pelos autores ${ }^{5}$ à melhor capacidade de fluxo ou de escoamento das resinas quimiopolimerizáveis. HANSEN; ASMUSSEN $^{86}$ também avaliaram a adaptação marginal das resinas compostas e observaram que, quando adesivos dentinários eram utilizados, o 
comportamento frente à contração de polimerização da mesma forma dependeu de variáveis tais como fluxo e módulo de elasticidade. BAUSCH et al. ${ }^{9}$ descreveram que a contração de polimerização com maior significado clínico é a que ocorre a partir da transformação gradual do líquido viscoso em um material rígido, que irá gerar tensões só compensadas pelo fluxo do material.

As resinas fotopolimerizáveis resultam em maior separação das margens que as resinas quimicamente ativadas, quando a irradiação acontecer perpendicularmente ao longo eixo da restauração, causando contração horizontal da camada superficial.

Quando uma resina é inserida em uma cavidade e aderida às suas paredes, pouco se conhece sobre o fluxo do material, entretanto, quando este for polimerizado livremente, a resina composta contrairá em direção à fonte de luz ou em direção ao centro da restauração, dependendo do sistema de ativação empregado. Por outro lado, caso exista adesão às paredes cavitárias, poderá acontecer que a resina ceda sem gerar tensões nas paredes ou desadapte dessas paredes, podendo ainda gerar tensões internas no material. Caso a resina composta possua flexibilidade suficiente, as tensões geradas durante a polimerização poderão ser compensadas, porém, em resinas com alto módulo de elasticidade não ocorre essa compensação, acontecendo em consequiência rachaduras e degradação do material, além de sua desunião das paredes cavitárias.

HEDGAHL; GJERDET ${ }^{91}$ verificaram que os dados referente às forças de contração linear de algumas resinas quimicamente ativadas indicaram que, quanto mais a resina se contrai durante a polimerização, maior será o estresse desenvolvido quando a mesma for contida. $\mathrm{O}$ estresse dependerá da resiliência da estrutura na qual a resida estará aderida.

Parecem ser grandes as diferenças entre as medidas das forças de contração e de tensão que ocorrem no esmalte sadio, podendo-se concluir que o estresse atuante nessa 
estrutura é baixo comparado às forças de tensão que ali ocorrem o que provavelmente não acontecem em se tratando de dentina.

Ainda com relação aos estresses gerados durante a contração de polimerização, ASMUSSEN $^{5}$ correlaciona a largura da fenda com a quantidade de monômero diluído observando que, quanto maior o conteúdo deste, menor será a viscosidade e maior a contração volumétrica.

KEMP-SCHOLTE; DAVIDSON ${ }^{102}$ esclarecem que o aumento das partículas de carga na composição da resina composta, assim como a diminuição de monômeros diluentes, não reduzem a formação de fendas marginais, mesmo porque estas modificações aumentam o módulo de elasticidade e a viscosidade do material, promovendo maiores tensões durante a contração de polimerização.

Pelos resultados de seus estudos, TORSTENSON; BRÄNNSTRÖM ${ }^{192}$ constataram que as duas resinas químicas de micropartículas testadas, associadas ao scotchbond reduziram consideravelmente a largura dos "gaps", mas as cavidades restauradas com as resinas híbridas apresentaram somente um ligeiro decréscimo na largura destes. As mudanças dimensionadas dos "gaps" variaram de acordo com a baixa temperatura, aumentando em aproximadamente $5 \mathrm{um}$. Uma alta temperatura, por outro lado, não alterou a largura dos mesmos.

Na Dentística Restauradora, a adesão é apontada como responsável pela redução de fendas criadas na interface entre os materiais restauradores e a estrutura dentária remanescente, consequentemente, uma ótima adesão estaria relacionada com a redução da microinfiltração junto a estas interfaces ${ }^{51}$. Em seus estudos, MONDELLI et al. ${ }^{131}$ relataram que a característica da superfície atacada é de fundamental importância para a resistência da união, por ser no interior dessa superfície rugosa que a resina escoa formando os tags, os 
quais constituem prolongamentos filamentosos responsáveis em aumentar a magnitude da ligação mecânica do adesivo à estrutura dentária, correspondendo à base da retenção. A qualidade da adesão pode ser atribuída à capacidade do sistema adesivo umectar a superfície e penetrar nos microespaços criados pela ação da solução condicionadora, formando um íntima relação, inicialmente com as substâncias inorgânicas do tecido dental, ao mesmo tempo que se liga quimicamente com a resina restauradora ${ }^{131}$.

Assim como pode ser observado no presente estudo e no de BOTELHO $^{17}$, a resina química reduz a microinfiltração marginal na interface dente/restauração em comparação às resinas compostas fotopolimerizáveis. De maneira semelhante, os resultados do estudo de LÜSCHER et al. ${ }^{117}$, avaliando a microinfiltração marginal e a adaptação das restaurações de resinas compostas, indicaram que a combinação de um selante adesivo de baixa viscosidade em associação ä resina composta quimicamente ativada, melhora consideravelmente a adaptação marginal e inibe a microinfiltração em cavidades preparadas de acordo com os princípios de restauração adesiva. Supõe-se que, nestes casos, as forças geradas durante a contração de polimerização não excedem a força de adesão mecânica entre o material, margens e paredes cavitárias.

Existem, por outro lado, estudos que apresentam resultados diferentes. ARAÚJO et $\mathrm{al}^{3}$. verificaram que, tanto a resina fotoativada quanto a quimioativada, permitem aproximadamente o mesmo índice de infiltração em restaurações de classe II, empregando-se as resinas P-10 e P-30 associadas ao Schotchbond, observando-se para as restaurações com resina fotoativada uma porcentagem ligeiramente inferior de microinfiltração, sendo que a maior porcentagem desta, independente dos fatores em estudo, ocorreu sempre ao nível 3, ou seja, com infiltração atingindo ou ultrapassando a parede axial. O condicionamento reduziu de $70 \%$ para $55 \%$ o percentual de infiltração observado. As duas resinas empregadas propiciaram 
exatamente a mesma infiltração, como demonstrado no trabalho de GROSS et al. ${ }^{78}$, cujos resultados também não indicaram haver diferença significante quanto à infiltração marginal ao utilizarem os mesmos materiais (P-10 e P-30), observando porém ter ocorrido infiltração do agente corante na região cervical de todas as restaurações. Talvez estes resultados possam ser explicados tomando por base a composição da fase orgânica das duas resinas, uma vez que ambas apresentam o sistema monomérico Bis-GMA e 48\% do monômero TEGMA, conforme informam RUYTER; YSAED ${ }^{174}$.

Pelo exposto, observa-se que vários são os fenômenos e procedimentos relacionados à configuração cavitária, ao emprego de resinas quimicamente ativadas, de baixo módulo de elasticidade, ao tempo de sorpção de água, às técnicas restauradoras, os quais, caso bem entendidos e aplicados, contribuem para minimizar clinicamente os efeitos da contração de polimerização, oferecendo às restaurações melhor qualidade e longevidade.

A tendência atual está voltada para o aprimoramento das resinas compostas quimicamente ativadas que, até então estavam sendo pouco usadas, uma vez que a técnica restauradora realizada através da combinação destes materiais com as resinas fotoativadas passou a ser recomendada com o objetivo de direcionar a contração de polimerização mais para a estrutura dentária do que para o centro da massa do material restaurador, combinando assim as vantagens das resinas fotopolimerizáveis inseridas nas áreas superficiais com a contração direcionada das resinas químicas inseridas nas áreas internas das restaurações. 


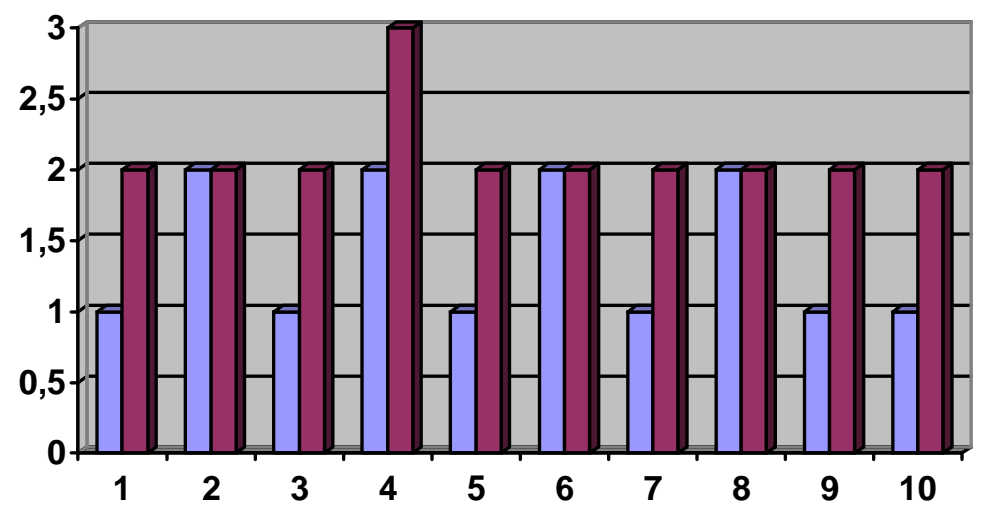

FIGURA 5.4.1 - Gráfico representativo individual em escores do índice de penetração do corante na interface cemento/Concise e cemento/Z-100-Concise controle.

\section{5 - Condição experimental grupo 2 (Natural Flow/Z-100) e grupo 3}

\section{(Aeliteflo/Z-100)}

Os valores individuais (figura 5.2.1) e a mediana (figura 5.2.3) apresentados pelas resinas fluídas Natural-Flow e Aeliteflo, demonstraram, que elas se comportaram de modo similar a resina convencional Concise ativada quimicamente e inferior ao Dyract. Todavia, essas duas resinas apresentaram capacidade de vedamento estatisticamente superior à resina convencional Z-100 e ao amálgama. Apesar de apresentarem escores de penetração do corante inferior ou mais satisfatórios do que uma resina de baixa viscosidade como as Z-100, ainda assim não impediram totalmente a infiltração marginal. É difícil apontar qual o fator ou fatores que influíram nesta tendência de melhorar o vedamento cervical: a condição física de 
maior fluidez, direcionamento da contração pela técnica de inserção e polimerização, à distância do foco de luz ou a intensidade da mesma. Pode-se inferir que todos esses aspectos contribuíram para uma melhor desempenho das resinas fluídas comparadas a resinas convencional Z-100, senão vejamos:

A resina não se contrai em direção à fonte de luz; de fato, nunca se contraiu. Esta afirmação exige necessariamente uma explicação, porque é contrária aos princípios fundamentais que dirigiram as técnicas restauradoras diretas nos últimos quinze anos e que, em grande parte, poderia explicar porque muitas, para não dizer quase todas, não funcionaram. Em 1982, HANSEN $^{84}$ escreveu na introdução de um artigo científico o seguinte: "Os vetores de contração das resinas são dirigidos até a fonte de luz", e desenvolvem uma metodologia que comprovaria esta hipótese. Surpreendentemente na discussão desse mesmo artigo, HANSEN ${ }^{84}$ comenta que não haveria sido possível comprovar a hipótese e que a resina havia seguido um padrão de contração diferente ao proposto e agrega: "Aparentemente existem outros fatores, não conhecidos até agora, que modificam o comportamento da resina ao polimerizar".

A partir deste artigo, não se sabe porque estranha razão, já que nem o autor acreditava mais na sua hipótese, todos começaram a afirmar que a resina se contraía em direção à fonte de luz. A resina composta, é inserida geralmente por incrementos, os quais são de aproximadamente $2 \mathrm{~mm}$ de espessura. O que $\mathrm{HANSEN}^{86}$ mencionava na sua hipótese era que a resina necessariamente se contraía em direção à fonte de luz, porque esta alcançava primeiro sua superfície e depois a parte profunda. Então, as cadeias de polímeros em formação sempre “devoraria" as novas moléculas até a luz. Houve somente um pequeno detalhe que esquecemos: a velocidade da luz é de $300.000 \mathrm{Km} /$ segundo. Isto eqüivale a dar 7,5 voltas ao 
redor da Terra num segundo, e que num incremento de $2 \mathrm{~mm}$ de espessura daria alguma diferença.

A luz irradia tecnicamente de forma simultânea a resina, porém pode-se questionar (mas a velocidade da luz na matéria é menor). A velocidade da luz é uma das 17 constantes físicas conhecidas pelo homem da atualidade, e por isso Einstein pode utilizá-la para demonstrar a sua Lei de Relatividade. Se bem que pode existir um atraso ao chocar os fotones (que viajam à velocidade da luz) com os átomos no interior da matéria, mas isso é insignificante num incremento de $2 \mathrm{~mm}$ de espessura. Outro argumento que se propôs (não se sabe em que momento e nem por quem, mas defendido por muitos) está relacionado ao grau de polimerização. Aqui se defende o seguinte: a luz chega com mais intensidade à superfície de restauração (o que está correto) e existe uma maior concentração nessa área que vai fazer com que o resto da restauração se desloque neste sentido o qual não é correto pelo seguinte:

A parte profunda da restauração terá um modo de elasticidade (rigidez) muito baixa, devido ao seu menor grau de polimerização por falta de intensidade luminosa, isso faz com que a resina não se desloque como foi apregoado, mas se comporta como "amortecedor" das tensões que a resina cria durante sua polimerização, isto ocorre da seguinte maneira: a luz chega com toda sua intensidade na superfície e a resina polimeriza e se contrai. A resina em profundas onde a luz é débil se estende por flexibilidade e não se desloca até a superfície, nem perde a adesão para criar um espaço (gap). Um segundo fator, mais importante ainda, está relacionado ao comportamento da resina em condições distintas e explica qual seria o real comportamento deste material durante sua polimerização no interior de uma cavidade.

Deve-se distinguir duas situações muito diferentes: na primeira uma restauração realizada sem técnicas adesivas (ataque ácido + primer + adesivo) ao se polimerizar a resina, esta se contrai. Não existe nada que evite que a resina se contraia e a faz livremente. Pergunta- 
se: quanta força gerou essa resina? Obviamente a resposta será zero, porque não precisou criar forças, já que se contraiu sem nenhum impedimento. Ao se analisar a segunda situação, onde se usou técnicas adesivas ao se polimerizar a resina, esta tratará de se contrair, mas estará aderida às paredes (superfície aderida) e, em função disto, não poderá fazê-lo (contração restrita). Nesta situação a resina começa a gerar forças que superam a força do adesivo: coloca-se ponto final na adesão com essa disputa.

Felizmente, em toda restauração existe um lugar de escape de forças onde a resina pode se contrair livremente. É a superfície livre da cavidade ou da restauração. Até onde a resina se contrai então? Até as paredes da cavidade. Bem, aqui o problema parece fácil. Se a resina se contrai até as paredes da cavidade, porque se preocupar com a perda da adesão?

Poderiam as coisas serem tão simples assim. Existe porém um pequeno detalhe que pode alterar tudo em alguns casos: uma cavidade convencional tipo caixa tem mais de uma parede e, cada parede se contrapõe à do lado oposto. A ocorrer este jogo de tensões, é óbvio que perde a parede onde existia o valor mais baixo de adesão. Cada configuração cavitária com sua respectiva restauração é uma situação particular e este é o motivo pelo qual as resinas compostas são muito sensíveis à técnica. Deve-se evitar enfrentar mais de duas paredes durante a polimerização, isto é obtido com a técnica incrementar diagonal como a utilizada nesta pesquisa. Esta pelo pequeno volume dos incrementos minimizam a magnitude das forças de contração de polimerização, responsável pelo estresse na interface entre as paredes cavitárias rígidas e o material restaurador.

Em cavidades onde a superfície livre é ampla como nas classes $\mathrm{V}$ e facetas, não é necessário a técnica incremental. 
A técnica incremental diminui o estresse gerado durante a contração de polimerização, além de favorecer à adaptação, densificação, eficácia de polimerização e a possibilidade de associar materiais restauradores diferentes, como a "técnica do sanduíche" aqui empregada.

Apesar dos incrementos neste trabalho apresentarem em algumas situações um diâmetro maior que $2 \mathrm{~mm}$, o tempo de exposição à luz polimerizadora de 60 segundos para cada incremento $\left(20 \mathrm{~s}-210 \mathrm{~mW} / \mathrm{cm}^{2}\right.$ e $\left.40 \mathrm{~s}-580 \mathrm{~mW} / \mathrm{cm}^{2}\right)$ proporcionou energia luminosa suficiente para uma conversão satisfatória do monômero em polímero, já que o único fator significante, influenciando na conversão do monômero é a duração da exposição ${ }^{66}$. HANSEN; ASMUSSEN $^{85}$ analisaram a relação entre a profundidade de polimerização e a distância de irradiação e concluíram que essa relação decresce de forma linear quando há um aumento na distância entre a saída da fonte de luz à superfície do material, ressaltando ainda, que mesmo em cavidades proximais profundas, estas resinas podem ser polimerizadas suficientemente quando forem utilizadas fontes polimerizadoras efetivas e se necessário, o tempo de polimerização prolongado. Assim, sob o ponto de vista didático e clínico pode- se simplificar o conceito de que os aparelhos fotopolimerizadores mais potentes não são melhores, como afirmam os fabricantes e/ou vendedores destes dispositivos. É importante o dentista saber que a contração de polimerização "é a conseqüência da reorganização molecular num espaço menor ao requerido durante a fase fluída". Isto é, as moléculas estão em movimento na fase líquida e, quando o material solidifica ou endurece, as moléculas se aproximam. Existe um fluxo de material em uma contração, já que é uma mudança volumétrica. As ligas metálicas quando passam do estado líquido (fundidas) para o estado sólido também se contraem. É uma contração de solidificação. A água é o único elemento que se expande ao se solidificar na forma de gelo. Como visto anteriormente, a resina ao se polimerizar segue dois caminhos: se contrai ou gera tensões. Essa contração na superfície livre necessita de tempo para se 
movimentar e, as lâmpadas mais potentes não permitem esse tempo, geram tensões pela rápida velocidade de polimerização, a qual rompe a ligação adesiva das paredes cavitárias.

Ao falar de lâmpada deve-se obter um conceito claro: é a dose de irradiação que determina a polimerização e suas consequiências. Pode-se irradiar uma resina como um lâmpada de $600 \mathrm{~mW} / \mathrm{cm}^{2}$ por 30 segundos e a polimerização será igual como se tivesse radiado a mesma resina com uma lâmpada de $300 \mathrm{~mW} / \mathrm{cm}^{2}$ por 60 segundos, mas ao se observara ambos exemplares, o segundo filtrará antes que o primeiro. A razão disto é que no primeiro exemplo, tudo aconteceu de uma maneira mais brusca geraram forças de contração.

Tão pouco não é cômodo estar polemizando a resina por minutos, por isso, desenvolveram lâmpadas que o início são fracas e depois são fortes, com as quais estão obtendo bons resultados e, diferente da lâmpada à laser com altíssimo intensidade, com as quais os resultados tem sido péssimos.

Outro fator importante é a distância, com o qual se pode de certa forma influenciar a intensidade. Inicialmente a $1 \mathrm{~cm}$ (a intensidade diminui 50\%) para logo se aproximar o mais possível. Acredita-se que a polimerização é um campo onde deve ocorrer algumas mudanças dentro de pouco tempo. Provavelmente, a propriedade mais importante na qual as forças de contração se interagem, seja o módulo de elasticidade. Quando o material possui mais carga inorgânica, geralmente o módulo de elasticidade será maior (a menos que se trabalhe com cargas de baixo módulo de elasticidade) e o material mais rígido.

Materiais rígidos não absorvem forças criadas durante a polimerização, enquanto que os materiais mais flexíveis o fazem e em consequiência sua transmissão de força até a interface adesiva será menor.

Ao aumentar a carga a resina se contrai com mais força, apesar de se contrair menos porque tem maior porcentagem de carga e menor porcentagem de resina orgânica. 
Esta é a base científica para o desenvolvimento das resinas fluídas e que segundo os fabricantes e alguns autores possuem um bom potencial para evitar perda da adesão durante a polimerização da resina composta restauradora. Estas devem ser usadas como base ou forrador cavitário e agir como "amortecedor" das forças ou tensões desenvolvidas abaixo das resinas em todas as restaurações de risco como é o caso das cavidades cuja parede gengiva localiza-se em cemento. Já que seu módulo de elasticidade é baixo, teoricamente vai gerar baixa intensidade de força durante sua contração e, em conseqüência melhor vedamento marginal. Para tanto, a camada de resina fluída precisa possuir propriedades mecânicas especiais que lhe permita contornar o problema de desadaptação, não devendo ser apenas fluída e flexível, mas também suportar as tensões geradas pela contração de polimerização.

Com relação a estes aspectos, a literatura especializada informa pelo trabalho de RUSSEL; MAZER ${ }^{173}$ em 1998, avaliaram a infiltração marginal quando uma resina com baixo módulo de elasticidade (resina flow ou de baixa viscosidade) foi utilizada como base, em molares com cavidades de classe II restauradas com Z-100; não encontrara influencia destes materiais em impedir a infiltração na parede cervical destas cavidades, não confirmando os resultados aqui obtidos. Da mesma forma, MIRANDA ${ }^{128}$ em 1999, também investigando o uso dessas resinas de baixo módulo de elasticidade, na tentativa de minimizar a infiltração em restaurações em resinas compostas condensáveis submetidos a carregamento oclusal, não encontrou nenhuma influência destes materiais em impedir a infiltração da solução corante. As dificuldades técnicas em aplicar esse material intermediário em uma camada uniforme, porém não houve diferenças entre os grupos com ou sem resina de baixo módulo como material intermediário. A diferença de comportamento das resinas fluídas nas pesquisa desse autor ${ }^{128}$ nas quais elas não influíram na porcentagem de infiltração marginal, com o comportamento aqui verificado (tendência em diminuir a infiltração) pode ser devida 
as marcas comerciais diferentes e a ciclagem mecânica e carregamento oclusal efetuado previamente à imersão na solução corante.

Em comparação, FRANCCI et al. ${ }^{69}$ avaliaram a infiltração marginal em restaurações de resina composta, comparando a eficiência de uma resina condensável e uma convencional com ou sem o uso de resina de baixo módulo de elasticidade como material intermediário. Seus resultados mostraram que a utilização de uma resina fluída (flow-it) como base formadora diminuiu a extensão da infiltração significantemente.

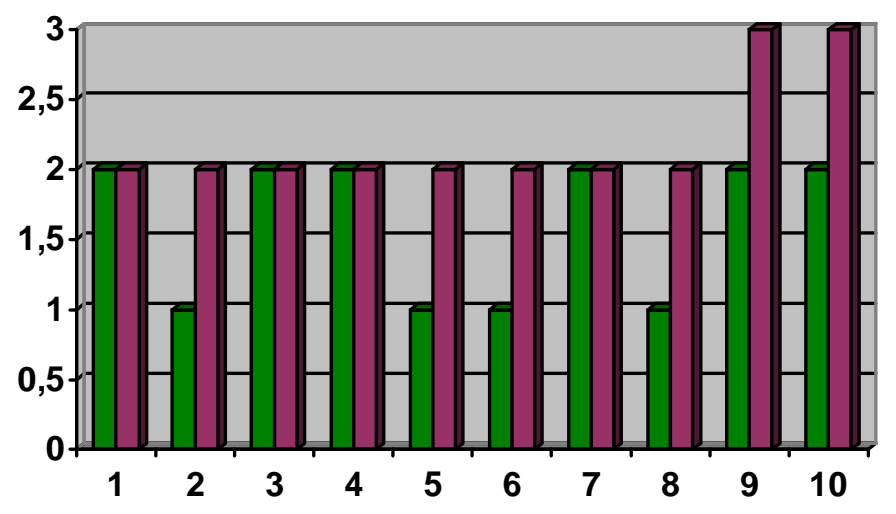

FIGURA 5.5.1 - Gráfico representativo individual em escores do índice de penetração do corante na interface cemento/Natural Flow e cemento Z-100- (controle). 


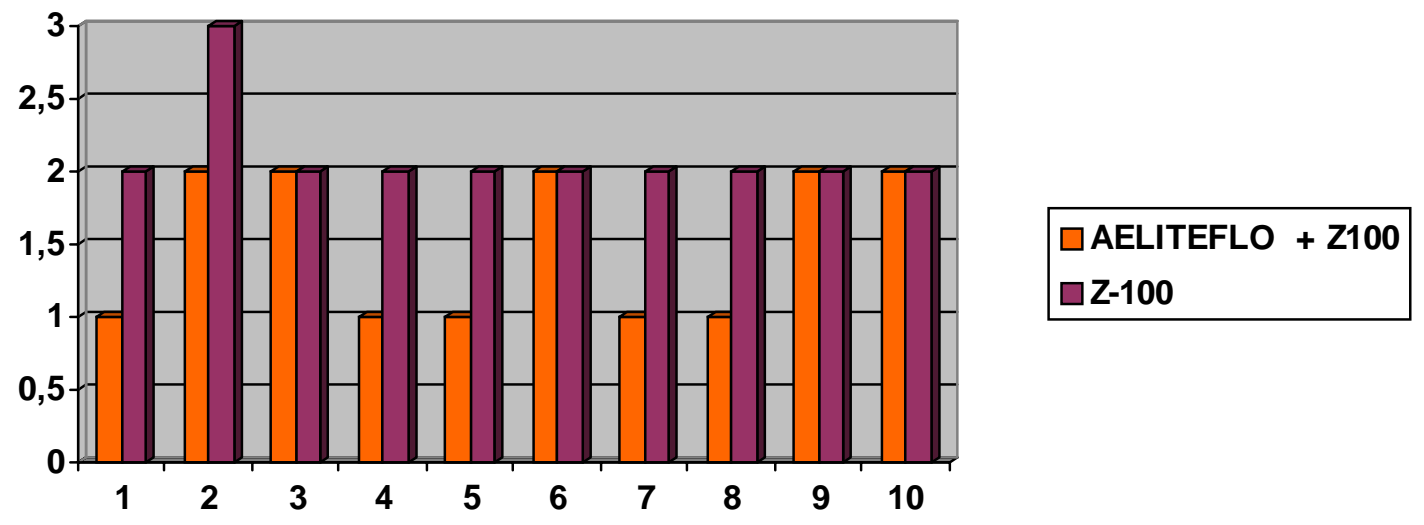

FIGURA 5.5.2 - Gráfico representativo individual em escores do índice de penetração do corante na interface cemento/Aeliteflo e cemento/Z-100 (controle).

\section{6 - Condição 4 (Dyract-AP/Z-100)}

Uma $4^{\mathrm{a}}$ alternativa clínica foi proposta para ser testada no presente estudo, considerando que os compômeros podem ser agora considerados como um dos mais versáteis materiais odontológicos utilizado sem dentística, demonstrando serem materiais promissores na prevenção de cáries (selamento de cicatrículas e fissuras), restaurações de classe II, I em função de suas características altamente favoráveis.

A habilidade do material restaurador minimizar a microinfiltração na interface material/estrutura dentária é fundamental para assegurar clinicamente o sucesso e durabilidade da restauração. Para isso, uma base de compônero tem sido sugerida como uma conveniente associação com as resinas compostas na técnica de "sanduíche", pois este material adere-se à dentina e esmalte, libera flúor e pode ser condicionado. 
A aceitação de novos produtos como os cimentos ionômericos modificados por resina, levou ao aparecimento de outra categoria de materiais de mesma natureza que os cimentos ionoméricos, também apresentando propriedades de liberação de flúor e algumas outras características destes cimentos, porém em um índice limitado; são as resinas compostas modificadas por poliácidos, também conhecidas por compômeros. A maioria destes produtos é erroneamente chamada de ionômero de vidro, uma vez que não apresentam a reação ácidobásica típica dos verdadeiros cimentos ionoméricos, sendo unicamente fotopolimerizáveis, como é o caso do Dyract, e do Dyract-AP e o Freedom. Este material, assim como as resinas fluídas (grupo 2 e 3), foram utilizados em associação à resina composta Z-100, para restaurar através da "técnica do sanduíche" as cavidades MOD dos espécimes referentes aos grupos 2, 3 e 4 na tentativa de se obter um procedimento alternativo que fosse eficaz em reduzir a infiltração marginal comumente observada nas restaurações estéticas diretas de dentes posteriores.

Os dados registrados na figura 5.2.8 comprovam que a menor média de penetração do corante na interface cervical das restaurações está relacionada com o grupo $4(0,6)$ para o qual, escores individuais apresentados na figura 5.6.2 registram para este grupo (DyractAp/Z-100) ocorrência na grande maioria dos espécimes de um índice suave de infiltração, com aproximadamente $40 \%$ dos espécimes isentos de infiltração marginal. Foi observada diferença significante do ponto de vista estatístico, entre esta condição experimental, distinguindo-se a mesma significantemente quando comparadas aos demais grupos.

Estes resultados confirmam os obtidos por BOTELHO ${ }^{17}, \mathrm{PIN}^{158}, \mathrm{FRIEDL}^{70}$ os quais foram realizados na tentativa de solucionar o sério problema da infiltração marginal em restaurações plásticas, principalmente de resina composta com margem cervical terminando 
em cemento e/ou dentina, utilizando com sucesso o Dyract e o Dyract-AP, como material intermediário destas restaurações, com a finalidade de favorecer o vedamento marginal.

Os adesivos resinosos demonstraram limitações na resistência de união à dentina, assim como muitas dúvidas permanecem sobre a longevidade dessa união. Por este motivo, a procura por agentes que propiciem menor infiltração e boa retenção direciona-se aos cimentos ionoméricos e aos compômeros reenfatizando a técnica mista ou "técnica do sanduíche" e destacando a sua importância. Esta técnica está de um modo geral indicada para a restauração de qualquer cavidade que apresente dentina exposta, inclusive em cavidades de classe II, quando inexistir esmalte na margem cervical, uma vez que as restaurações de resinas compostas realizadas em tais situações são caracterizadas por deficiente adaptação marginal. A ineficiência dos adesivos dentinários em bloquear a infiltração marginal ocasionou a necessidade do surgimento de uma técnica tal qual a técnica do "sanduíche", que fosse capaz de solucionar este grave problema, preferencialmente eliminando ou secundariamente minimizando a infiltração marginal.

O bom desempenho dos compômeros em minimizar a infiltração marginal deve-se às suas características de adesão química aos tecidos dentários, similar aos cimentos ionoméricos, favorecendo o selamento marginal; das propriedades físicas, principalmente no que diz respeito ao coeficiente de expansão térmica, semelhantes à dentina, e da propriedade de liberação de íons flúor, o que reduz o desenvolvimento de cáries secundárias. Assim sendo, esses dois fatores os tornam superiores as resinas compostas, contribuindo para a manutenção do vedamento marginal e para maior longevidade dessas restaurações em comparação com as resinas compostas usadas nos procedimentos restauradores que envolvem preparos de classe II com limite cervical localizado em cemento. 
Estes aspectos fazem com que os compômeros apresentem um ótimo vedamento marginal a curto e longo prazo, a despeito de sua resistência adesiva à dentina ser inferior àquela conseguida com os sistemas adesivos resinosos. Essa qualidade de vedamento, associada ao potencial anticariogênico e antibacteriano, colocam os compômeros como excelente opção para material de vedamento da área cervical associado às resinas compostas nas restaurações de classe II com parede gengival em cemento e/ou dentina.

No trabalho desenvolvido por PIN ${ }^{158}$, também ficou constatado a superioridade da “técnica do sanduíche”, utilizando o cimento ionomérico Vitremer e o compômero Dyract em associação à resina composta para restaurar cavidades de classe II estendidas ao cemento, tendo sido constatada isenção de penetração do corante na maioria dos espécimes, concordando com o presente estudo pelo fato de ter sido constatada para a maioria dos espécimes uma suave infiltração, restringida às margens das restaurações. Sob outro aspecto, porém, o trabalho de PIN $^{158}$, obtendo um índice suave de infiltração (Escore 1) para o grupo representado pelo tradicional Dyract, confirma totalmente esta pesquisa, a qual constatou a efetividade do mesmo material quando utilizado para vedar a margem cervical em cemento.

Contrariando os estudos acima mencionados, são encontrados na literatura, trabalhos de autores ${ }^{33,66,193 \text {, }}$ não detectaram diferença significativa do ponto de vista estatístico entre o emprego ou não de cimentos de ionômeros de vidro modificados ou resinas compostas modificadas por poliácidos utilizados como base, quanto à qualidade de adaptação marginal.

Embora em seus estudos FRIEDL et al. ${ }^{70}$ não tenham observado diferenças estatísticas significante entre as cavidades esteticamente restauradas seja pela técnica convencional ou através da "técnica do sanduíche", estes pesquisadores concluíram que os cimentos ionoméricos híbridos e os compômeros possuem ótima qualidade de selamento marginal e devem ser usados em associação à resina composta como técnica alternativa para as 
restaurações estéticas de classe II. Neste estudo $^{70}$, foi utilizada a resina TPH em associação ou não ao Dyract e a resina Z-100 em associação ou não ao Vitremer. Embora a análise estatística não tenha apresentado significância entre as quatro condições experimentais, os melhores resultados de microinfiltração marginal foram condizentes aos espécimes restaurados pela técnica do sanduíche, com valores ligeiramente menores para o Dyract em comparação ao Vitremer, resultado este que concorda com esta investigação, na qual o Dyract-AP se comportou satisfatoriamente.

Segundo PRATI et al. ${ }^{160}$ e PERDIGÃO et al. ${ }^{143}$, o grave problema da infiltração marginal em cavidades de classe II com margens localizadas em cemento se deve principalmente às mudanças dimensionais sofridas pelas resinas compostas, sendo que, a contração de polimerização ocorrentes nesses materiais pode ser reduzida com os cimentos de ionômero de vidro híbridos utilizados como base, através da técnica do sanduíche ${ }^{70}$. Embora possuindo o inconveniente de contrair-se durante a polimerização, os valores dessa contração correspondentes aos ionômeros híbridos chegam à metade dos alcançados pelas resinas compostas fotopolimerizáveis. O coeficiente de expansão térmica linear dos compômeros (resinas compostas modificadas por poliácidos) está próximo ao das resinas compostas de micropartículas (64.2 para 60.0 respectivamente).

Segundo informações do fabricante ${ }^{52}$, o Dyract-AP permite alta força de adesão e capacidade para absorver água, o que pode ser suportado pelos resultados de penetração do corante deste trabalho, no qual o Dyract-AP apresentou o menor índice de infiltração após a termociclagem.

LIN et al. ${ }^{113}$ demonstraram que a adesão dos ionômeros modificados por resina e das resinas modificadas por poliácidos (compômeros), se deve a uma associação dos mecanismos básicos de adesão química, mais uma adesão micromecânica alcançada pela penetração dos 
componentes do material na estrutura dentinária, demonstrando haver, segundo CARVALHO et al. ${ }^{24}$, uma camada de interação micromecânica semelhante à camada híbrida encontrada na interface da dentina com as resinas compostas, entre esses e a dentina. Este fenômeno é mais evidente nos materiais que apresentam um agente ácido de pré-condicionamento dentinário.

Com relação ao Dyract, $\mathrm{HALLER}^{82}$ relata que o prime\&Bond usado não remove a smear layer e sim torna esta camada infiltrada pelo agente resinoso. Esta camada elástica reduz o estresse durante a contração de polimerização causada pelo compósito associado ao Dyract na técnica mista. De acordo com as informações do fabricante, o Dyract contém UDMA (uretanodimetacrilato), a resina TCB (ácido tatrabutanocarboxílico) e o estrônciofluorsilicato-vítreo. O primer PSA contém PENTA, TEGMA e uma resina elástica. Por este motivo, o Dyract é mais parecido com uma resina de baixo módulo de elasticidade, necessitando portanto de condicionamento ácido prévio. Após sua aplicação, cria-se uma camada de smear layer infiltrada com ácido PENTA enfraquecido, facilitando a penetração da smear layer pelo monômeros hidrofílicos, que possuem afinidade aos componentes orgânicos e inorgânicos da superfície dentinária exposta sob a smear layer.

Segundo Carvalho et al. ${ }^{24}$, a possibilidade de formação da camada híbrida parece ser a melhor forma de unir as resinas poliácido modificadas ao dente, através da hibridação.

A alta umidade dentinária resultante da permeabilidade dos fluídos pulpares, principalmente em dentina profunda, tem sido reportada como causa da deficiente adesão de alguns sistemas adesivos à dentina. Por outro lado, os cimentos de ionômero de vidro e os compômeros são aparentemente menos sensíveis à umidade dentinária, oferecendo valores semelhantes de adesão em diferentes graus de permeabilidade e umidade dentinária. Esses aspectos fazem com que os cimentos ionméricos e os compômeros apresentem um ótimo vedamento marginal, a despeito de sua resistência adesiva à dentina ser inferior àquela 
conseguida com os sistemas adesivos resinosos. Essa qualidade de vedamento, associada ao potencial anticariogênico e antibacteriano, colocam os compômeros como excelente opção para material de forramento e/ou vedamento de cavidades de classe II que se estendem até o cemento dentário.

Dentre os trabalhos encontrados na literatura, direcionados no sentido de avaliar a adesão dos cimentos ionoméricos modificados por resina e resinas compostas modificadas por poliácidos, convém citar o estudo desenvolvido por FRITZ; FINGER; UNO ${ }^{71}$, através do qual os autores afirmam que qualquer sistema adesivo pode ser efetivo quando utilizado em combinação com esta nova geração de materiais, desde que tenha um maior efeito na desmineralização, para facilitar a exposição da malha de colágeno e facilitar o molhamento desta pelo monômero, possibilitando a formação da camada híbrida. Trabalho de CARVALHO et al. ${ }^{24}$ comprova esta hipótese, demonstrando através de testes de resistência de união e de fotomicrografias que realmente existe a formação da camada híbrida, tanto para as resinas modificadas por poliácidos, Variglass e FUJI LC II, quanto para o cimento ionomérico modificado por resina, Vitremer. 


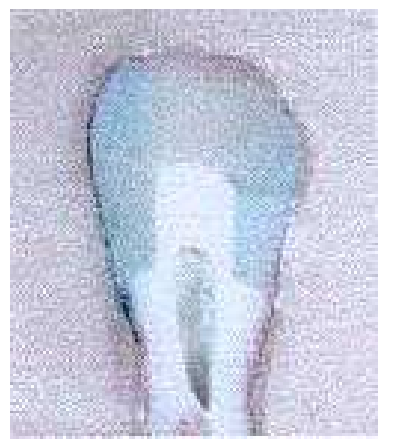

FIGURA 5.6.1 - Ilustração fotográfica característica do índice moderado de microinfiltração correspondente ao escore 1 (Dyract-AP) lado direito, resultante na interface concise/cemento em $60 \%$ dos espécimes do grupo e, escore 2 do lado esquerdo (Z-100).

A maioria dos trabalhos desenvolvidos com o intuito de testar a infiltração marginal em restaurações realizadas com os ionômeros modificados por resina e resinas modificadas por poliácidos afirmam na sua quase totalidade ${ }^{136,183}$ BOTELHO $^{17}$ que, o que ocorre, é uma substancial diminuição e não um impedimento total da infiltração marginal na interface dente/restauração.

Todavia, é óbvia a melhoria no vedamento marginal quando se emprega resina poliácido modificada, Dyract-AP comparada aos demais materiais testados no presente estudo. Contudo, espera-se que a infiltração marginal associada ao emprego desses materiais seja mascarada pela propriedade de liberação de flúor dos mesmos, evitando o desenvolvimento de cáries secundárias.

Analisando a literatura apresentada e os resultados obtidos pelo presente trabalho de pesquisa, supõe-se que as restaurações envolvendo compômeros em associação às resinas compostas (restaurações sanduíche), se apresentam como a melhor alternativa para bloquear a infiltração marginal em cavidades onde inexiste esmalte na margem cervical ou, quando esta 
for deficiente em qualidade, representando a médio e a longo prazo um benefício para a restauração. Contudo, estudos a longo prazo são requeridos no sentido de esclarecer o verdadeiro mecanismo de adesão, sensibilidade à água, estabilidade de cor e propriedades mecânicas destes novos materiais e conseqüente redução da infiltração marginal. O bom desempenho do Dyract-AP, confirma os resultados obtidos por BOTELHO ${ }^{17}$ para a mesma condição experimental.

Apesar do bom desempenho alcançado com o emprego do Dyract-AP (Grupo 4) e na pesquisa de BOTELHO $^{17}$ este material apresentou resultados superiores ao Dyract. Este resultado na pesquisa de BOTELHO $^{17}$ foi inicialmente incompreensível, por se tratar de dois produtos de mesma composição química e marca comercial. Não havendo explicação na literatura para esclarecer tal ocorrência, tornou-se necessário solicitar esclarecimentos diretamente ao fabricante. Assim sendo, a composição química do Dyract tradicional e do Dyract-AP continua a mesma; a única diferença entre estes dois produtos refere-se ao tamanho das partículas de carga. Embora a quantidade de carga seja a mesma, o tamanho das partículas no produto tradicional varia entre 1 a 5 um de diâmetro e, já no Dyract-AP, estas são correspondentes a 0,8 um, melhorando dessa forma o escoamento e o resultado do polimento das restaurações. O fabricante esclareceu que, alterando-se o tamanho das partículas de carga do material, altera-se consequentemente suas propriedades físicas, como módulo de elasticidade e flexibilidade, solubilidade e maior expansão higroscópica, propriedades essas que, como já mencionado, favorecem a qualidade da adaptação do material às paredes cavitárias. Nesta explicação embasam-se os resultados favoráveis do Dyract-AP em relação ao Dyract convencional, no que diz respeito à microinfiltração marginal na região do cemento verificada na pesquisa de BOTELHO ${ }^{17}$. 
Talvez neste momento seja conveniente mencionar o fato de existir, com relação a vários dos trabalhos revisados e discutidos, uma dúvida por muitas vezes parecer que os autores empregam resinas compostas modificadas por poliácidos referindo-se a estes produtos como se fossem cimentos ionoméricos modificados por resina, o que pode interferir na interpretação dos resultados. Esta é de certa forma uma questão polêmica, pois a nomenclatura destes novos materiais tem sido discutida entre os pesquisadores. Os fabricantes incluem muitos deles erroneamente como cimentos ionoméricos. No Brasil, alguns adotaram os termos "compômeros" ou "ionopósito", como uma maneira genérica de se referir aos "híbridos" de cimento de ionômero de vidro com monômeros resinosos. Estes termos não existem na concepção química ${ }^{23}$. Pelo $2^{\circ}$ Simpósio Internacional de Ionômero de vidro, realizado em 1994 (Philadelphia), estes materiais não foram classificados na categoria dos cimentos de ionômero de vidro modificados por resina, por não possuírem a reação ácidobase de autopolimerização, típica dos verdadeiros ionômeros, característica esta capaz de promover o endurecimento, ainda que não completo, na ausência de luz. Resinas compostas modificadas por poliácidos, parece corresponder ao termo mais apropriado para esta categoria de materiais.

No entanto, é interessante notar que o Dyract-AP o único material a apresentar resultado altamente satisfatório, destacando-se estatisticamente dos grupos 1, 2, 3 e 5 (figura 5.2.2), os quais apresentaram média de penetração do corante aproximada do grupo controle (figura 5.2.4), observando-se na maioria dos espécimes um índice suave de infiltração marginal na região de cemento. (figura 5.2.2).

Os resultados alcançados pelos espécimes restaurados com o Dyract-AP (Grupo-4) levam a crer no fato de realmente existir uma semelhança entre esses produtos e as resinas compostas de micropartículas. Nestes produtos, as propriedades mecânicas iniciais são 
normalmente altas e a liberação de flúor normalmente baixa quando comparados com os verdadeiros cimentos ionoméricos ${ }^{23,146}$ comportamento das resinas compostas modificadas por poliácidos se assemelha mais ao de uma resina composta com capacidade mensurável de liberar flúor, podendo apresentar portanto um certo potencial anticariogênico.

A estrutura do componente resinoso de alguns materiais modificados por poliácidos pode ser mais rígida e menos capaz de sofrer deformação elástica que outros, no estágio inicial de polimerização ${ }^{83}$, sugerindo talvez que o Dyract-AP seja capaz de sofrer maior deformação quando da incidência de forças geradoras de estresses tanto provenientes da contração de polimerização, das variações térmicas ou sob cargas oclusais, mantendo em conseqüência a qualidade da adaptação.

Os resultados obtidos pelo grupo 4 (Dyract-AP) permite afirmar, desde que se utilize os materiais de modo apropriado, que a técnica do "sanduíche" favorece o vedamento marginal em restaurações de classe II com margens cervicais em cemento. 


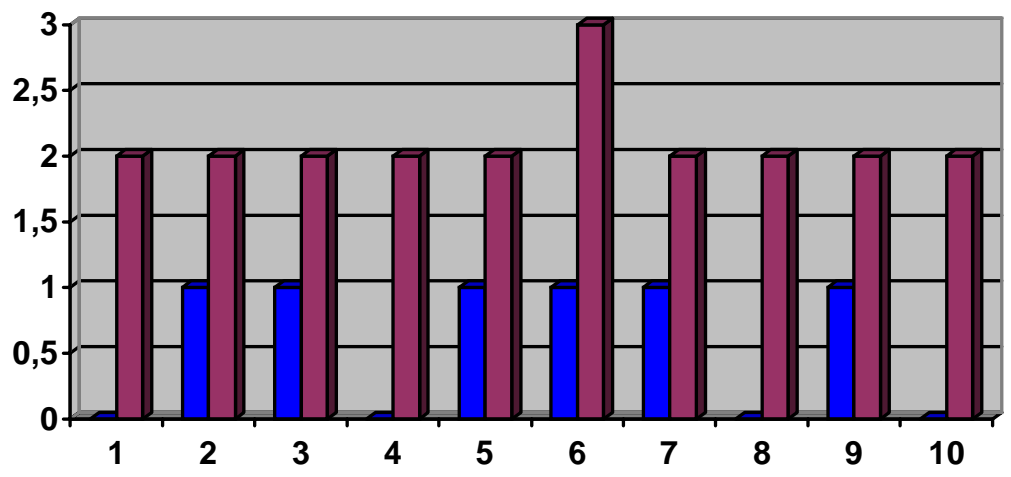

FIGURA 5.6.2 - Gráfico representativo individual em escores do índice de penetração do corante na interface cemento/Dyract e do cemento/z-100 (controle).

\section{7 - Condição: Amálgama/Z-100}

Examinando os resultados (figura 5.2.1) pelos testes de infiltração marginal observada ao nível das interfaces parede gengival/ restauração. Observou-se: Índice de penetração do corante consideravelmente maior para o grupo V (Velvaloy + Z-100), vindo a seguir em ordem decrescente, o grupo II (Natural Flow + Z-100), grupo III (Aeliteflo + Z-100), grupo I ( Concise + Z-100) e finalmente o grupo IV (Dyract + Z-100) com menor escore.

As comparações individuais pelo teste de Student-Newman-Keuls (figura 5.2.5) demonstram existir diferença estatisticamente significante do grupo 5 com os demais, devido ao maior índice de infiltração marginal (escore 3), ou seja, com penetração do corante atingindo ou ultrapassando a parede axial. Esse maior índice de infiltração observado nas restaurações de resina associada ao amálgama pode ser devido ao pequeno tempo de 
armazenamento dos corpos de prova, não tendo sido suficiente para salientar uma das propriedades mais importantes desse material restaurador, ou seja, sua propriedade autoselante. A formação dos produtos de corrosão que promovem o vedamento cavitário necessitariam de um período mais prolongado.

As restaurações de resina compostas na região posterior, sejam de classes I ou II, podem ser consideradas de maneira geral como corretamente indicadas, nas situações em que a maior parte das forças do dente antagonista recaírem sobre o esmalte remanescente sadio, sendo de responsabilidade do material apenas reconstruir e selar o tecido dentário perdido. A indicação da resina nessa região apoia-se principalmente nos problemas inerentes ao mercúrio associado às restaurações de amálgama ou simplesmente por legítima consideração estética, o que vem decrescendo a porcentagem de utilização desse material. A realidade é que muitos profissionais estão utilizando a resina composta rotineiramente, de maneira indiscriminada, para restaurar cavidades de classe II ou mesmo em substituição às restaurações de amálgama em excelente estado. A indicação da resina composta para dentes posteriores deverá ficar limitada aos casos de fundamental importância estética, pois, mesmo com toda a melhoria apresentada pelas resinas compostas no que diz respeito às suas propriedades físicas e mecânicas, estes materiais ainda não podem ser considerados substitutos para as restaurações de amálgama e sim uma alternativa a mais para a restauração de dentes posteriores.

Assim sendo, uma alternativa clínica para promover melhor adaptação, prevenindo ou diminuindo a infiltração marginal e garantindo a estética em cavidades de classe II, seria a aplicação de outros materiais na parede gengival, capazes talvez de selar efetivamente as interfaces das restaurações quando combinados com as resinas compostas, associando desta maneira as propriedades vantajosas inerentes aos diferentes materiais utilizados. 
Portanto, o amálgama, o cimento de ionômero de vidro modificado por resina, as resinas compostas modificadas por poliácidos, bem como a resina composta quimicamente ativada, foram os materiais selecionados neste estudo para, em associação à resina composta fotopolimerizável serem testados quanto ao vedamento marginal cervical das restaurações.

A técnica mista combinando amálgama e resina composta foi a Segunda condição experimental sugerida neste trabalho, objetivando associar as vantagens desses dois materiais restauradores.

Apesar de existirem várias opções restauradoras para dentes posteriores, o amálgama continua ainda sendo um dos materiais de escolha pela maioria dos cirurgiões dentistas e isto se deve primordialmente à sua durabilidade, resistência ao desgaste e aos esforços mastigatórios, facilidade de inserção e manipulação e por ser um material restaurador de emprego direto, tudo isto associado ao baixo custo e a seu efeito bacteriostático ${ }^{11}$. Além da facilidade de manipulação e inserção em fase plástica na cavidade preparada, este material permite boa adaptação às paredes cavitárias, podendo ser esculpido com facilidade, permitindo a obtenção da forma anatômica desejada.

Esperava-se, com o emprego da técnica mista, utilizando o amálgama Velvalloy com interposição de um verniz cavitário, em associação à resina composta Z-100, uma tendência de melhoria do vedamento marginal nas restaurações correspondentes ao grupo 5, Talvez, pelo fato da avaliação Ter sido realizada em período de 48 horas após os procedimentos restauradores, $80 \%$ dos espécimes apresentaram índice máximo de infiltração marginal na interface cervical, ou seja, houve penetração do corante ao nível ou além da parede axial, como caracterizado na figura 5.7.1. Apenas dois espécimes apresentaram escores 2, com penetração do corante atingindo metade da parede gengival. 


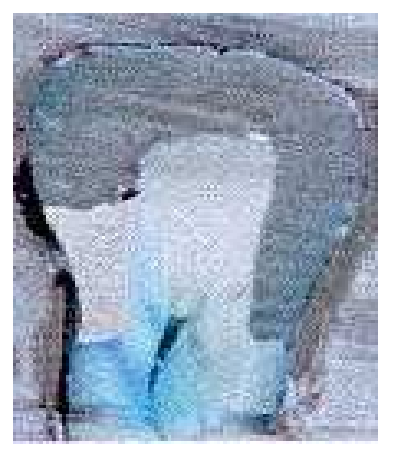

FIGURA 5.7.1- Ilustração fotográfica caracterizada da severa microinfiltração (escore 3), resultante no grupo 5 na interface cemento/amálgama.

O amálgama dental é o único material adontológico atualmente conhecido que possui a característica peculiar de reduzir com o tempo a infiltração em torno das restaurações, por sua capacidade de aumentar o vedamento marginal tardiamente, e que se deve ao depósito dos produtos resultantes de sua corrosão na interface dente/restauração ${ }^{11,21,128}$. O processo de corrosão acontece mais rapidamente com a utilização de ligas convencionais ${ }^{11}$, ocorrendo com as ligas de alto conteúdo de cobre um vedamento semelhante somente após um período de dois $\operatorname{anos}^{2}$.

Possivelmente, a explicação para o deficiente vedamento marginal observado nas restaurações recentes seja o fato de ainda não terem sido formados os produtos de corrosão, uma vez que o verniz cavitário não foi eficaz em prevenir a microinfiltração precoce nestas restaurações.

O amálgama possui uma desvantagem, que é a falta de adesão aos tecidos dentários, o que exige muitas vezes a necessidade de retenções mecânicas adicionais, com o sacrifício de tecido dentário sadio que, somando a um preparo incorreto e/ou falha na manipulação do material, podem levar a um maior risco de microinfiltração marginal e insucesso clínico. 
Com o objetivo de vedar a interface amálgama/estrutura dentária até que se formem os produtos de corrosão, o verniz cavitário tem sido aplicados nas paredes cavitárias previamente à inserção deste material, sendo sua efetividade em reduzir ou prevenir a microinfiltração precoce nestas restaurações questionada, por se tratar de um material passível de dissolução 159 , pela possibilidade de falhas na película durante sua aplicação ${ }^{101}$, agindo apenas como barreira mecânica ${ }^{11}$, criando-se assim um ambiente totalmente desfavorável ao crescimento microbiano, o que pode ser importante na prevenção de cáries secundárias. A capacidade deste produto em diminuir a microinfiltração inicial em restaurações de amálgama foi verificada por vários autores ${ }^{11,101,103}$, sendo também tradicionalmente aplicado como isolante elétrico.

A velocidade de formação dos produtos de corrosão e a conseqüente redução da infiltração marginal são aspectos difíceis de serem interpretados. MURRAY; YATERS; WILLIANS ${ }^{140}$ observaram resultados semelhantes de infiltração marginal em restaurações de amálgama com verniz Copalite, nos períodos de 1 e 7 dias, 3 e 6 meses. Por outro lado, MOORE JOHNSON; KAPLA ${ }^{139}$ observaram diferenças nos índices de infiltração marginal comparando os períodos de 1 semana e seis meses. PALAGHIAS ${ }^{149}$ e KOZONO et al $^{106}$ alegaram que o intervalo de 6 meses seria suficiente para a formação dos produtos de corrosão, mas para WRIGHT et al. ${ }^{203}$ oito semanas já seriam suficientes para a ocorrência de tal processo.

Vários trabalhos ${ }^{11,30101}$, também encontrados na literatura, demonstram, que existe controvérsia com relação à eficácia do verniz, por ser solúvel ${ }^{159}$, poderá se dissolver durante o armazenamento e/ou termociclagem, antes mesmo que ocorra o deposito dos produtos de corrosão e não prevenir a microinfiltração ${ }^{11,101}$. 
Se por um lado o amálgama associado à resina composta parece promissor no controle da microinfiltração em cavidades de classe II com margem em cemento, como afirmado por EIDELMAN $^{56}$ e FRANCCI; SANTOS ${ }^{69}$ ao observarem uma significante redução na microinfiltração nesses tipos de restaurações, indicando o seu procedimento para restaurar esteticamente cavidades de classe II, por outro lado, autores como BOTELHO ${ }^{17}$, observaram resultados semelhantes aos alcançados pelo presente estudo, encontrando para todos os espécimes um índice severo de infiltração marginal na interface amálgama/cemento, indicando que essa técnica é inefetiva em reduzir precocemente a infiltração nas margens cervicais estendidas à região de cemento, o que se deve além da precária adesividade aos tecidos dentais às diferenças no coeficiente de expansão térmica. Este problema só será superado com o passar do tempo, através da progressiva corrosão que o amálgama sofre em sua interface com a parede cavitária, promovendo uma efetiva proteção contra a microinfiltração, ao contrário do deficiente selamento proporcionando por uma restauração recente.

Pelo exposto, conclui-se que para avaliar os resultados de estudos laboratoriais é necessário considerar as diversificadas metodologias aplicadas bem como o tipo de liga empregada, da forma de suas partículas, do preparo cavitário ${ }^{11}$, dos materiais intermediários, da lama dentinária ${ }^{11}$, da forma de condensação do amálgama, do brunimento da restauração e do meio ao qual ficarão expostas as restaurações.

Apesar desse trabalho não ter avaliado o índice de penetração do corante na interface amálgama/resina composta, outros avaliaram, defendendo a existência de uma excelente interface, devido à penetração do adesivo nas irregulariedades e porosidades da superfície do amálgama, criando uma aderência com a resina composta ${ }^{81,126}$, caso a superfície do amálgama ser polida, as irregulariedades são eliminadas ${ }^{81,126}$. Possivelmente possa ter 
ocorrido um alisamento da superfície do amálgama nesta pesquisa, durante sua regularização e remoção dos excessos, os quais poderiam interferir na colocação da resina. Segundo EIDELMAN $^{56}$, o grau de infiltração na interface amálgama/resina composta chega a ser menor que na interface resina/esmalte. Embora alguns pesquisadores ${ }^{46}$ realizem o condicionamento ácido da superfície do amálgama como rotina, de acordo com HADAVI; HEY; AMBROSE ${ }^{81}$, este procedimento não deve ser realizado, pois representa a ocorrência de um índice elevado de infiltração na interface entre este material e a resina composta, em função d maior dificuldade para remover completamente o ácido em forma de gel da superfície rugosa do amálgama, fator desfavorável à boa adesão.

O fator estético consiste na grande limitação das restaurações de amálgama, sendo este o principal responsável pela busca de uma resina composta específica para restaurações posteriores que, além de ser esteticamente superior, se une micromecanicamente à estrutura dentária quando associada ao condicionamento ácido e aos sistemas adesivos, resultando num aumento da resistência do remanescente dental à fratura ${ }^{21}$.

Os resultados apresentados pelo grupo 5 contra-indicam portanto o emprego da técnica mista, amálgama/resina, no sentido de minimizar precocemente a infiltração marginal em restaurações de classe II. Mas, para que se possa predizer com certeza o comportamento clínico deste tipo de restauração, torna-se essencial o desenvolvimento de pesquisas longitudinais, "in vitro" e "in vivo", analisando e associando as diferentes propriedades do material. 


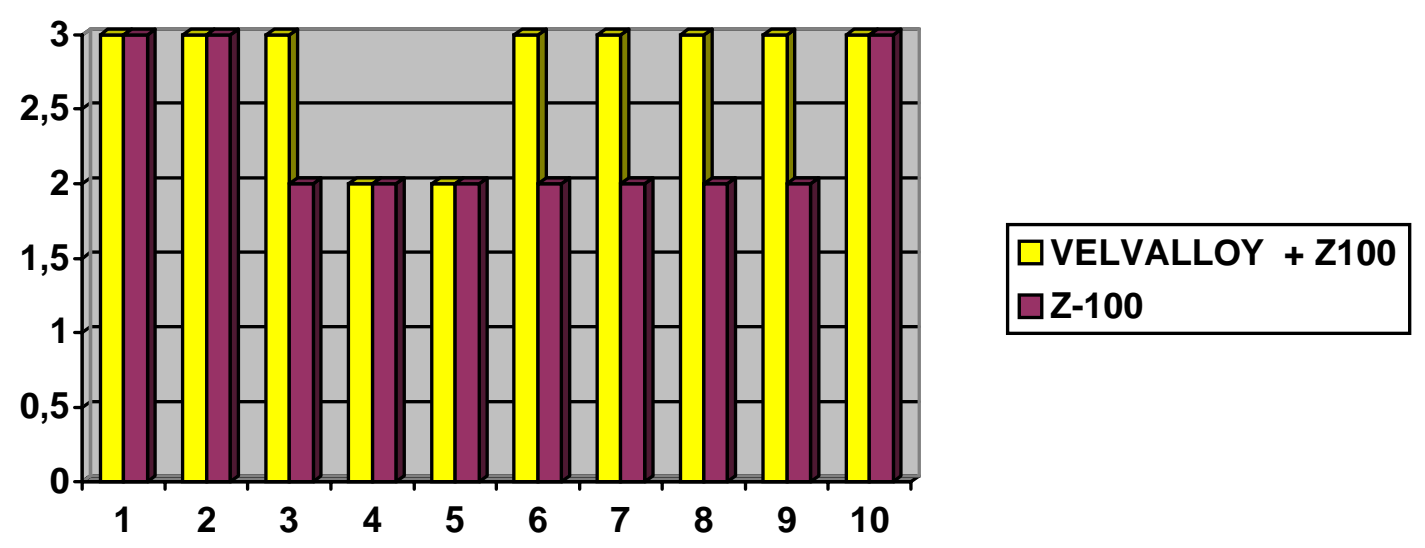

FIGURA 5.7.2 - Gráfico representativo individual em escores do índice de penetração do corante na interface cemento/Velvalloy e cemento/Z-100 (controle).

\section{8 - Considerações finais}

Os avanços nas técnicas e nos materiais restauradores levaram a uma melhora na união das resinas compostas às paredes cavitárias. Entretanto, a diversidade entre os substratos dentários, diferenças estruturais e morfológicas regionais dos mesmos, sensibilidade técnica dos materiais e vulnerabilidade frente ao ambiente bucal e esforços oclusais a que estão sujeitos indicam que os sistemas restauradores adesivos ainda necessitam de correta indicação e controle dessas variáveis para conseguir desempenhar com sucesso sua função no restabelecimento das estruturas comprometidas em dentes posteriores. $\mathrm{O}$ uso indiscriminado em cavidades extensas sujeitas a esforços mecânicos contínuos, as dificuldades do profissional em se inteirar das grandes mudanças nos sistemas adesivos, muitas vezes possibilitam a indicação e uso incorreto desses sistemas, além da utilização de procedimentos 
de inserção e polimerização inadequados, visando economia de tempo, continuam sendo fatores negativos, e os maiores responsáveis por insucessos das restaurações realizadas com resinas compostas em dentes posteriores.

Recentemente surgiram materiais indicados para restaurações posteriores chamadas "resinas condensáveis", "resinas empacotáveis", “amálgama branco", “amalgam like materials", etc. Em outras palavras, um material tão fácil de manipular e tão fiel como o amálgama de prata. Não importa como se utiliza o material os resultados serão bons, afirmam os fabricantes.

A resina composta demorou quase 30 anos para ser um excelente material, mas como os odontólogos não o puderam compreender, precisa-se de um material disponível tão benévolo como o amálgama para poder trabalhar.

Aqui há alguns pontos a esclarecer ${ }^{27}:$ 1) Estes materiais são resinas compostas, com uma viscosidade maior e mais nada; 2) contém uma alta porcentagem de carga, que nem sempre é adequada, o que torna algumas marcas comerciais altamente viscosas e difíceis de trabalhar. Por outro lado, a incorporação dentro da matriz de cargas do tipo "fibra de vidro", num tamanho que oscila entre 8 a 10 micrômetros é um fator importante sob o ponto de vista clínico. Elas se comportariam como uma séria de "microespelhos" com possibilidade de refletir a luz halógena e tornar possível a sua penetração nos lugares mais distantes da matriz orgânica; 3) uso de resinas fluídas como base, o que parece lógico, pois funcionaram relativamente bem nesta pesquisa, sendo superadas apenas pelos compômeros na técnica do sanduíche; 4) para a superfície oclusal são ótimas porque sua forma anatômica não é alterada como no caso das resinas de baixa viscosidade e a facilidade com que permitem obter pontos e/ou relação de contatos proximais apropriados. 
O que deve ficar bastante claro, é que a resina condensável não é amálgama nem se comporta como tal. É ilógico pensar que um material orgânico fundamentado em polímeros vai se comportar de maneira semelhante que uma liga metálica. A única finalidade que tem essa comparação que existe a nível mundial é o "marketing" de um produto dirigido a um setor que continua pensando que o amálgama é e será insuperável, e tentam fazer-lhes acreditar que o que estão comprando é um "amálgama branco". Se realmente se deseja ter êxito com as resinas condensáveis, é necessário tratá-las como resinas compostas, com técnica incremental diagonal e todo o exposto anteriormente, e não como se fosse amálgama, que de fato não é.

Se na prática clínica as resinas compostas apresentam complicações freqüentes, como sensibilidade pós-operatória, e ainda que se esforço para ter os últimos adesivos que não conseguem solucionar o problema, as sugestões aqui testadas e os comentários feitos ajudará ao profissional a entender um pouco melhor o complexo que é o comportamento viscoelástico dos polímeros ou resinas compostas.

Para concluir, com uma técnica clínica adequada e uma seleção também adequada de materiais e, finalmente, compreendendo que cada cavidade é uma situação particular que requer critério clínico, esses problemas irão ficando para trás e pouco a pouco o dentista se tornará mais "íntimo" de um material tão espetacular como as resinas, que tem a particularidade de não funcionar com quem não as querem entender. 
6 CONCLUSÃO 


\section{6 - CONCLUSÕES}

Com base nas diferentes condições experimentais propostas e nos resultados estatísticos dos valores obtidos concluíu-se:

- O amálgama Velvalloy e a resina composta Z-100 usada como controle apresentaram respectivamente os índices mais severos de infiltração marginal, na interface cemento/material restaurador;

- Houve diferença estatística significante entre o Dyract AP e os demais materiais testados o qual reduziu consideravelmente o índice de infiltração marginal nas interfaces das restaurações;

- A resina quimicamente ativada Concise e as fluídas Aeliteflo e Natural Flow ocuparam uma posição intermediária com relação à infiltração marginal, com desempenho estatisticamente igual entre si e desfavoravelmente em relação ao Dyract AP; por outro lado, sobressaíram-se positivamente em comparação ao amálgama;

- Não obstante o melhor comportamento apresentado pela resina composta modificada por poliácidos Dyract AP, observou-se que nenhum material restaurador utilizado foi apto em impedir $100 \%$ a penetração da solução corante nas margens cervicais em cemento. 
REFERÊNCIAS BIBLIOGRÁFICAS 


\section{REFERÊNCIAS BIBLIOGRÁFICAS}

1. ALANI, A.H.; TOH, C.G. Detection of microleakage around dental restorations; a review. Oper. Dent., v.22, n.4 , p.173-185 , July/Aug. 1997.

2. ANDREWS, J.T.; HEMBRE JÚNIOR, J.H. Marginal leakage of amalgam alloys with hight content of cooper: a laboratory study. Oper. Dent., v.5, n.1, p.7-10, Winter 1980.

3. ARAÚJO , M.A.M. et al. Avaliação da infiltração marginal na interface resina compostacimento de ionômero de vidro e deste com a dentina . Rev Odonto. UNESP, v.24, n.1, p.69-78, jan./jul. 1995.

4. ARAÚJO. R.M.; SILVA FILHO, F.P.M.; MENDES, A.J.D. Estudo da infiltração marginal em restaurações de resinas compostas para dentes posteriores, efeito do material, preparo cavitário e condicionamento do esmalte a nível cervical. Rev. Odont. UNESP, v.19, n.1, p.191-201, 1990.

5. ASMUSSEN, E. Composite restorative resins. Composition versus wall to wall polymerization contraction. Acta Odont. Scand., v.33, n.6, p.337-44, Nov,1975.

6. ÁVILA JÚNIOR, G. Estudo comparativo da infiltração marginal, com ciclagem térmica em restaurações feitas com diferentes materiais plásticos. Bauru, 1979, 74p. Dissertação (Mestrado) - Faculdade de Odontologia de Bauru, Universidade de São Paulo.

7. BARNES, D.M. et al. Microleakage of class 5 composite resin restorations: a comparison between "in vivo" and "in vitro". Oper Dent. v.18, n-6, p.237-45, Nov./Dec. 1993.

8. BASSIOUNY, M.A. A visible Light-cured Composite Restorative Material. Brit. Dent. J., v.145, n.11, p.327-30, Dec. 1978.

\footnotetext{
* Normas recomendadas para uso no âmbito da Universidade de São Paulo, com base no documento "Referências Bibliográficas: exemplos", emanado do Conselho Supervisor do Sistema integrado de bibliotecas da USP, em reunião de 20 de setembro de 1990.
} 
9. BAUSCH, J.R. et al. Clinical significance of polymerization shrinkage os composite resins J. prosth. Dent., v.48, n.1, p.59-67, July 1982.

10. BEN-AMAR, A. Reduction of microleakage around new amalgam restorations. J.Amer. dent. Ass., v.119, n.6, p.725-8, Dec. 1989.

11. BEN-AMAR.; CARDASH, H.S.; JUDES, H. The sealing of the tooth/amalgam interface by corrosion products. J. oral Rehab., v.22, n.2, p.101-4, Feb.1995.

12. BEM-AMAR, A. et al. Long-term use of dentin adhesive as na interfacial sealer under class II amalgam restorations. J. oral Reahab., v.17, n.1, p.37-42, Jan. 1990.

13. BERTOLOTTI, R.L. Posterior composite technique utilizing shrinkage and a novel matrix. Pract. Periodontics Aesthet. Dent., v.3, n.4, p.53-58, 1991.

14. BOWEN, R.L. Properties of silic reinforced polymer for dental restorations. J. Amer. dent. Ass., v.66, n.1, p.57-64, Jan. 1963.

15. BOWEN, R.L. Adhesive bonding of various materials to hard tooth tissues. Forces developing in direct felling materials during hardening. J. Amer. Dent. Ass., v.74, n.3, p.439-45, Feb. 1967.

16. BOWEN, R.L.; RAPSON, J.E.; DICKSON, G. Hardening shrinkage and hygroscopic expansion of composite resins. J. dent. Res., v.61, n.5, p.654--8, May 1982.

17. BOTELHO, A.M. Avaliação da infiltração marginal em cavidades de classe II restauradas com resina composta assocoada a outros materiais restauradores. Bauru, 1999. 263p. Tese (Doutorado) - Faculdade de Odontologia de Bauru, Universidade de São Paulo.

18. BRYANT, R.W. Direct posterior composite resin restorations: a review. 2. Clinical technique. Aust. dent. J., v.37, n.3, p.161-71, June 1992. 
19. BULLARD, R.H.; LEINFELDER, K.F.; RUSSELL, K.M. Effect of coefficient of thermal expansion on microleakage . J. Amer. dent. Ass. v.116 , n.7, p.871-4, June 1988.

20. BUONOCORE, M.G. A simple method of increasing the adhesion of acrylic materials to enamel surfaces. J. Dent. Res, v.34,n.6,p.349-353, 1955.

21. BUSATO, A.L.S.; BARBOSA, A.N.; BUENO, M. Dentística: restaurações em dentes posteriores. São Paulo, Artes Médicas, 1996.

22. CAMPISTA, C. de; CHEVITARESE, O. Permeabilidade marginal de restaurações de classe V com Scothbond Multi-Uso/Z-100, em função do momento do acabamento. Rev. Bras. Odont., v.52, n.4, p. 14-6, jul./ago. 1995.

23. CARVAlHO, RM. Ionômero de vidro. Maxi-Odonto: dentística, v.5, n.5, p.1-42, set./out. 1995.

24. CARVALHO, R.M. et al. Bonding mechanism of variglass to dentin. Amer. J. Dent., v.8, n.5, p.253-8, Oct. 1995.

25. CARVALHO, R.M. et al. A review of polymerization contraction: the influence stress development versus stress relief. Oper. Dent.,v.21, n.1, p.17-24, Jan./Feb. 1996.

26. CASTAÑEDA, J.C. Avaliação da microinfiltração em restaurações mistas de classe V.Bauru, 1991.201p.Dissertação (Mestrado). Faculdade de Odontologia de Bauru Universidade de São Paulo.

27. CASTAÑEDA, J.C. Paradigmas da la Odontologia Adesiva. Mundo Odontológico.,v.36, pag 24-8,1999.

28. CAUGHMAN , W.F., RUEGGEBERG, F.A. ; CURTIS Jr., J.W. Clinical guidelines for phtocuring restorative resins . J Amer. Dent. Ass.,v.126, n.9, p.1280-1286, Sep. 1995. 
29. CHAN, M.F. W-Y ; JONES, J.C.G. Significance of thermal cycling in microleakage analysis of root restorations. J. Dent., v.22, n.5, p.292-295, Oct/Nov. 1994.

30. CHAIN, M.C.; LEINFELDER, K.F.O estágio atual dos adesivos entinários. Rev Ass. paul. cirurg. Dent., v.47, n.6, p.1173-80, nov./dez. 1993.

31. CHAIN, M.C.; BARATIERI, L.N.; ARCARI, G. Estágio atual da técnica do sanduíche restaurações de ionômero de vidro + resina composta. Rev. Gaúcha Odont., v.38, n.5, p.341-5, set./out. 1990 .

32. COUNCIL ON DENTAL MATERIALS , INSTRUMENTS, AND EQUIPMENT Visible light-cured composites and activating units. J. Amer. dent. Ass., v.110, n.11, p.100103, Jan. 1985.

33. CRIM, G.A. Effect of immediate versus delayed thermal stress on two adhesives.

Quintessence Int. , v.20, n.7, p.517-9, July 1989.

34. CRIM, G.A.; CHAPMAN, K.W. Reduzing microleakage in class II restoration : an "in vitro" study. Quintessence Int. , v.25, n.11. p.781-5, Nov. 1994 .

35. CRIM, G.A.; GARCIA GODOY, G.F. Microleakage: the effect of storage and cycling duration. J. prosthet. Dent., v.57, n.5, p.574-6, May 1987.

36. CRIM, G.A.; MATTINGLY, S.L. Evaluation of two methods for assessing marginal leakage. J.prosth.Dent., v.45, n.2, p.160-3, Feb. 1981.

37. CRIM, G.A.; SWARTZ, M.L.; PHILLIPS, R.W. Comparison of four thermocycling techniques. J.prosth.Dent., v.53, n.1, p.50-3, Jan. 1985.

38. DARBYSHIRE, P.A.; MASSER, L.B.; DOUGLAS, W.H. Microleakage in class II composite restorations bonded to dentin using thermal and load cycling . J.dent.Res., v.67, n.3, p.585-7, Mar. 1988. 
39. DAVIDSON, C.L. Resisting the curing contraction with adhesive composites. J. prosthet. Dent., v.55, n.4, p.446-7, Apr. 1986.

40. DAVIDSON, C.L. Handling of polymerization stresses in composite restorations. In: INTERNATIONAL SYMPOSIUM "RECONSTRUCTIONS WITH CARBON FIBER SYSTEM AND THE OPTIMUM ADHESIVE SYSTEM", 2., S. Margherita Ligure, 1998. Proceedings. Milano, Hippocrates Edizioni Medico Scientificiche, 1998. p.22-5.

41. DAVIDSON, C.L.; ABDALLA, AI. Effect of thermal and mechanical load cycling on the marginal integrity of class II resin comparative restorations. Amer. J.Dent., v.6, n.1, p.39-42, Feb. 1993 .

42. DAVIDSON, C.L.; ABDALLA, ${ }^{\mathrm{a}}$ I. Effect of occlusal load cycling on the marginal integrity of adhesive class V restorations. Amer. J.Dent., v.7,n.2 , p.111-4, Apr. 1994.

43. DAVIDSON, C. L.; DE GEE, A. J. Relaxation of polymerization contraction stresses by flow in dental composites. J. dent. Res., v.63, n.2, p.146-8, Feb. 1984.

44. DAVIDSON, C.L.; FEILZER, A.J. Polymerization shrinkage and polymerization shrinkage stress in polymer-base restoratives. J. Dent., v.25, n.6, p.435-440, Nov. 1997 .

45. DEGRANGE, M apud SMITH, D.C.; VANHERLE, G. State of the art of direct posterior filing materials and detine bonding: summary of an International Simposium. J. Dent., v.22, n.2, p.123, Apr. 1994.

46. DEMARCO, F.F. et al. Avaliação da infiltração em cavidades classe II determinadas em cemento. In: Encontro do Grupo Brasileiro dos Professores de Dentística, 13, p.86, Recife, 1999. Anais./Resumo n.74/ 
47. DIETRICH, A.C. et al. Marginal adaptation of direct composite and sandwich restorations in class II with cervical margins in dentine. J. Dent., v.27 , n.2, p.119-128, Feb. 1999.

48. DIETSCHI, D et al. Influence of the restorative technique and new adhesives on the dentin marginal seal and adaptation of resin composite class II restorations : an in vitro evaluation. Quintessence Int., v.26, n.10, p.717-27, Oct. 1995.

49. DOERR, C.L; HILTON, T.J.; HERMESCH, C.B. Effect of thermocycling on the microleakage of conventional and resin-modified glass ionomers. Amer. J. Dent., v.9, n.1, p.19-21, Feb.1996 .

50. DONLY, K.S.; WILD , T.W.; JENSEN , M.E. Posterior composite class II restorations : in vitro comparison of preparation designs and restoration techniques. Dent. Mater., v.6, n.2 , p.88-93, Apr. 1990.

51. DUKE, E.S. Adhesion and is application witrh restorative materials. Dent. Clin. N. Amer., v.37, n.3, p.329-40, July 1993.

52. DYRACT AP - Advanced Performance Compomer Restorative; perfil técnico do produto.s.l., Dentsply De Trey, 1997.

53. EAKLE, W. S.; ITO, R. K. Effect of insertion technique on microleakage in mesiooccluso-distal composite resins restorations. Quint. Int., v.21, n.5, p.369-74, May 1990.

54. EAKLE, W. S.; NAKAMOTO, D. K. Microleakage in MOD resin composite with three dentin bonding agents. Dent. Mater., v.5, n.6, p.361-4, Nov. 1989.

55. EHRNFORD, L.; DERAND, T. Cervical gap formation in class II composite resin restorations. Swed. dent. J., v.8, p.15-9, 1984.

56. EIDELMAN, E. et al. A. Na Evaluation of Marginal Leakage of Class II Combined Amalgam-Composite Restorations. Oper. Dent., v.15, n.4, p.141-8, July/Aug. 1990. 
57. ELIADES, G. Clinical relevance of the formulation and testing of dentine bonding systems. J. Dent., v.22, n.2 , p.73-81, Apr. 1994.

58. FAYYAD, M.A.; SHORTALL, A.C.C. Microleakage of dentine-bonded posterior composite restorations. J. Dent., v.15, n.2, p.67-72, Apr,1987 .

59. FEILZER, A.J.; DE GEE, A. J.; DAVIDSON, C. L. Setting stress in composite resin in relation to configuration of the restoration. J. dent. Res., v.66, n.11, p.1636-9, Nov. 1987.

60. FEILZER, A.L.; DE GEE, A.J.; DAVIDSON, C.L. Quantitative determination of stress reduction by flow in composite restorations . Dent. Mater., v.6, n.3, p.167-171, July. 1990.

61. FEILZER, A.J.; DE GEE, A.J.; DAVIDSON, C.L. Setting stresses in composite for two different curing modes. Dent. Mat., v.9, n.1, p.2-5, Jan. 1993.

62. FERRACANE, J.L. Correlation between hardness and degree or conversion during the setting reaction of unfilled dental resins restorative resins. Dent. Mater., v.1, n.1, p.11-14, Feb. 1985.

63. FERRACANE, J.L. Using posterior composites appropriately J. Amer. dent. Ass., v.123, n.7, p.53-8, July 1992.

64. FERRACANE , J.L.; MITCHEM, J.C.; ADEY, J.D. Fluoride penetration into the hybrid layer from a dentin adhesive. Amer. J. Dent., v.11 , n.1, p.23-28, Feb. 1998.

65. FERRARI, M. The micromorphologic relationship between resin and dentin in class $\mathrm{V}$ restorations : an "in vivo and "in vitro" investigation. Quintessence Int., v.25, n.3, p.621-5, Sept. 1994. 
66. FERRARI, M.; DAVIDSON, C.L. Sealing capacity of a resin-modified glass-ionomer and resin composite placed in vivo in class 5 restorations. Oper. Dent., v.21, n.2, p.69-72, Apr. 1996.

67. FIELDS, H. W. et al. Variables affecting measurements of vertical occlusal force. J. dent. Res., v.65, n.2, p.135-8, Feb. 1986.

68. FORTIN, D.; PERDIGÃO , J.; SWIFT JUNIOR, E.J. Microleakage of three new dentin adhesives. Amer. J. Dent., v.7, n.6, p.315-8, Dec. 1994.

69. FRANCCI, C.E.; SANTOS, J.F.F. Microleakage in posterior teeth with "combined restorations" of Amalgam/Composite. J. dent. Res., v.76, p.419, 1997. Special issue./Abstract n.3242/

70. FRIEDL, K.H. et al. Marginal adaptation of composite Restorations. Oper. Dent., v.22, n.1, p.22-9, Jan/Feb. 1997.

71. FRITZ, U.B.; FINGER, W.J.; UNO, S. Marginal adaptation of resin-bonded light-cured glass ionomers in dentin cavities. Amer. J. Dent., v.9, n.6, p.253-8, Dec. 1996.

72. FUSAYAMA, T. Indications for self-cured and light-cured adhesive composite resins . J. prosth. Dent., v.67, n.1, p.46-51 Jan. 1992.

73. FUTATSUKI, M.; NAKATA, M. "In vitro" marginal leakage of class II composite resin restorations by thermal cycling. J. clin. pediat. Dent., v.18, n.3 , p.191-6, June,1994.

74.

75. GOING, R.E.; MASSLER, M.; DUTE, H.L. Marginal penetrations of dental restorations as studied by cristal dye. J. Amer. dent. Ass., v.61, p.285-300, Sept. 1960.

76. GONÇALVES, A. M. Influência do tipo de estresse e da interposição de ionômero de vidro para forramento na infiltração marginal de cavidades restauradas com dois 
sistemas adesivos restauradores. Bauru, 1996. 132p. Dissertação (Mestrado) Faculdade de Odontologia de Bauru, Universidade de São Paulo.

77. GORACCI, G. The latest discoveries in adhesion: recent studies. In: INTERNATIONAL SYMPOSIUM "RECONSTRUCTIONS WITH CARBON FIBER SYSTEM AND THE OPTIMUM ADHESIVE SYSTEM", 2., S. Margherita Ligure, 1998. Proceedings. Milano, Hippocrates Edizioni Medico Scientificiche, 1998. p.36-40.

78. GOTTLIEB, E.W.; RETIEF, D.H.; BRADLEY, E.L. Microleakage of conventional and high-copper amalgam restorations. J. prosth. Dent., v.53, n.3, p.355-61, Mar. 1985.

79. GROSS, J.D.; RETIEF, D.H.; BRADLEY, E.L. Microleakage of posterior composite restorations . Dent. Mater., v.1, n.1, p.7-10, Feb. 1985.

80. GROSSMAN, E.S.; MATEJKA, J.M. In vitro marginal leakage in varnished and lined amalgam restorations. J. prosth. Dent., v.69, n.5, p.469-74, May 1993.

81. GUZMAN, H.J.; SWARTZ, M.L.; PHILlIPS, R.W. Marginal leakage of dental restorations subjected to thermal stress. J. prosth. Dent., v.21, n.2, p.166-75, Feb. 1969.

82. HADAVI, F.; HEY, J.H.; AMBROSE, E.R. Assessing microleakage at the junction between amalgam and composite resin: a new method in vitro. Oper. Dent., v.16, n.1, p.6-12, 1991.

83. HALLER, B.; TROJANSKI, A.; KLAIBER, B. Marginal adaptation of direct class II composites using dentin adhesives. J. dent. Res., v.75, p.40, 1996. Special issue. /Abstract n.181/

84. HALLET, K.B.; GARCIA-GODOY, F. Microleakage of resin-modified glass ionomer cement restorations: an in vitro study. Dent. Mat., v.9, n.5/6, p.306-11, Sept. 1993. 
85. HANSEN, E.K. Visible light-cured composite resins: polymerization contraction, contraction pattern and hygroscopic expansion. Scand. J. dent. Res., v.90, n.4, p.32935, Aug. 1982.

86. HANSEN, E. K.; ASMUSSEN, E. Effect of postponed polishing on marginal adaptation of resin used with dentin-bonding agent. Scand. J. dent. Res., v.96, n.3, p.260-4, June 1988.

87. HANSEN, E.K.; ASMUSSEN, E. Marginal adaptation of posterior resins: Effect of dentin-bonding agent and hygroscopic expansion. Dent. Mat., v.5, n.2, p.122-6, Mar. 1989.

88. HANSEN, E. K.; ASMUSSEN, E. Visible light curing units: correlation between depth of cure and distance between exit window and resin surface. Acta Odont. Scand., v.55, n.3, p.162-66, June 1997.

89. HASEGAWA, T. et al. Marginal adaptation of two composites in a dentin cavity mediated with Single Bond. J dent. Res., v.78 , p.155, 1999. Special issue/Abstract n.398/

90. HASEGAWA, T.; RETIEF , D.H. Quantitative microleakage of some dentinal bonding restorative systems. Dent. Mater., v.9, n.2, p.114-117, Mar. 1993.

91. HASSAN, K. et al. A modified incremental filling technique for class II composite restorations. J. prosthet. Dent., v.58, n.2, p.153-6, Aug. 1987.

92. HEGDAHL, T.; GJERDET, N.R. Contraction stresses of composite resin filling materials. Acta Odont. Scand., v.35, n.4, p.191-5, July 1977.

93. HILTON, T. J.; SCHWARTZ, R. S.; FERRACANE, J. L. Microleakage of four class II resin composite insertion techniques at intraoral temperature. Quint. Int., v.28, n.2, p.135-44, Feb. 1997. 
94. HIRSCHFELD, Z. et al. Marginal leakage of class II glass-ionomer-composite resin restorations: an in vitro study. J. prosth. Dent., v.67,n.2,p.148-53,Feb. 1992.

95. HOOD, J.A.A.: BECCONSALL-JONES, K.M. Effect of stress on leakage of class. II glass ionomer/composite restorations. J. dent. Res., v.74, p.494, 1995. Special issue. /Abstract n.749/

96. HOVAV, S. et al. Microleakage of class II superbond lined composite restorations with and without a cervical amalgam base. Oper. Dent., v.20, p.63-5, 1995.

97. JENSEN, M. E.; CHAN, D. C. N. Polymerization shrinkage and microleakage. In: VANHERLE, G.; SMITH, D. C., eds. Posterior composite resin dental restorative materials. St. Paul, Minnesota Mining, 1985. p. 243-62.

98. JÖRGENSEN, K. D.; HISAMITSU, H. Class 2 composite restorations: prevention in vitro of contraction gaps. J. dent. Res., v.63, n.2, p.141-5, Feb. 1984.

99. JÖRGENSEN, K. D.; ASMUSSEN, E.; SHIMOKOBE, H. Enamel damages caused by contracting restorative resins. Scand. J. Dent. Res., v.83, n.2, p.120-2, 1975.

100. JORGENSEN, K.D.; MATONO, R.; SHIMOKOBE, H. Deformation of cavities and resin filings in loaded teeth. Scand. J. dent. Res., v.84, n.1, p.46-50, Jan. 1976.

101. KANCA III, J. Posterior resins: microleakage below the cementoenamel junction. Quintessence Int., v.18,n.5,p.347-49, May 1987.

102. KARAMURSEL-ULUKAPI, K. et al. Comparison of the sealing ability of four cavity varnishes: an in vitro study. Dent. Mat., v.7, n.2, p.84-7, Apr. 1991.

103. KEMP-SCHOLTE, C.M.; DAVIDSON, C.L. Complete marginal seal of class V resins composite restorations effected by increase flexibility. J. dent. Res., v.6, n.6, p.1240-3, June 1990.

104. KIDD, E.A.M. Microleakage : a review. J. Dent., v.4, n.5, p.199-206, Sep. 1976. 
105. KIDD, E. A. M.; HARRINGTON, E.; GRIEVE, A. R. The cavity sealing ability of composite restorations subjected to thermal stress. J. Oral Rehab., v.5, n.3, p.27986, July 1978.

106. KOENIGSBERG, S.; FUKS, A.; GRAJOWER, R. The effect of three filling techniques on marginal leakage around class II composite resin restorations in vitro. Quint. Int., v.20, n.2, p.117-21, Feb. 1989.

107. KOZONO, Y. et al. Dissolution of amalgam in saline solution. J. Biomed. Mater. Res., v.16, n.6, p.767-74, Nov. 1992.

108. LALSINGH, C. et al. Effect of curing lights on microleakage in class V compositive restorations. J. dent. Res., v.78, p.306, 1999. Special issue/Abstract n.1601/

109. LAMBRECHT, P. et al. BRAEN, M.; VANHERLE, G. Buonocore memorial lecture. Evalution of clinical performance for posterior composite resins and dentin adhesives. Oper.Dent., v.12, n.2, p.53-78, Spring 1987.

110. LAMOSA, A.C. et al. Avaliação do efeito da termociclagem na adesão de adesivos dentinários de $5^{\mathrm{a}}$ geração. In: Encontro do Grupo Brasileiro de Professores de Dentística, 13, p.68, Recife 1999. Anais./Resumo n.37/

111. LEÃO, S.F.S.; DA SILVA, R.B.; EMERENCIANO, N.S. Avaliação da infiltração marginal: efeito do condicionamento ácido, primer e umidade do substrato. In: Encontro do Grupo Brasileiro dos Professores de Dentística, 13, p.77, Recife1999. Anais./Resumo n.55/

112. LEINFELDER, K.F. Posterior composite resin. J. Amer. dent. Ass., v. 117, n.4, p.216, Sept. 1988. Special issue.

113. LEINFELDER, K. F. Using composite resin as a posterior restorative material. J. Amer. Dent. Ass., v.122, n.4, p.65-70, Apr. 1991. 
114. LIN, A.; MC INTYRE, N.S.; DAVIDON, R.D. Studies on the adhesion of glassionomer cements to dentin. J. dent. Res. V.71, n.11, p.1836-41, Nov. 1992.

115. LINDEN, J.J.; SWIFT JUNIOR, E.J. Microleakage of two new dentin adhesives . Amer. J. Dent., v.7, n.1, p.31-4 Feb. 1994.

116. LÖSCHE, G.M. Marginal adaptation of class II composite fillings: guided polymerization vs reduced light intensity. J. adhesive Dent., v.1, n.1, p.31-9, 1999.

117. LUNDIN, S.A.; NORÉN, J.G. Marginal leakage in occlusally loaded, etched, class-II composite resin restorations. Acta odont.scand., v.49, n.4, p.247-54, Aug. 1991.

118. LÜSCHER, B. et al. Microleakage and marginal adaptation of composite resin restorations. J. prosth. Dent., v.39, n.4, p.409-13, Apr. 1978.

119. LUTZ, F. et al. Improved proximal adaptation of class II composite resin restorations by use of light-reflecting wedges. Quint. Int., v.17, n.10, p.659-64, Oct. 1986.

120. LUTZ,F.; KREJCI,I.; OLDENBURG, T.R. Elimination of polymerization stresses at margins of posterior composite resins restorations: a new restorative technique. Quintecensse Int., v.17, n.12, p.777-84, Dec. 1986.

121. MAHLER, D.B.; NELSON, L.W. Sensitive answers sought in amalgam alloy microleakage study. J. Amer. dent. Ass., v.125, n.3, p.282-8, Mar. 1994.

122. MANDERS, C.A.; GARCIA-GODOY, F.; BARNWELL, G.M. Effect of a copal varnish, ZOE or glass-ionomer cement bases on microleakage or amalgam restorations. Amer. J. Dent., v.3, n.2, p.63-9, Apr. 1990.

123. MANDRAS, R. S.; RETIEF, D. H.; RUSSEL, C. M. The effects of thermal and occlusal stresses on the microleakage of the Scotchbond 2 dentinal bonding system. Dent. Mater., v.7, n.1, p.63-7, Jan. 1991. 
124. MARTIN, F.F.; BRYANT, R.W. Acid etching of enamel cavity walls. Aust. Dent. J., v.29, n.5, p.308-14, Oct. 1984.

125. MAZER, R. B.; RUSSELL, R. R. Should flowable composites be used as liners for class II restorations? J. dent. Res., v.78, p.389, 1999. Special issue. /Abstract n.2266/

126. McLEAN, J.W.; WILSON, A.D.; PROSSER, H.J. Development and use of waterhardening glass-ionomer luting cements. J. prosth. Dent., v.52, n.2, p.175-181, Aug. 1985.

127. MELlO, A.L.A.; CUNHA, A.V.M.; CONCEIÇÃO, E.N. Avaliação da microinfiltração em cavidades classe II utilizando as associações ionômero fotopolimerizável-resina composta e amálgama-resina composta. Rev. Fac. Odont. Porto Alegre, v.33, n.2, p.2-3, dez. 1992.

128. MICHAILESCO, P.M. et al. An vivo recording of variations in oral temperature during meals: a pilot study. J.prosth. Dent., v.73, n.2, p.214-8, Feb. 1995.

129. MIRANDA JÚNIOR, W. G. et al. Microleakage of condensable composite resins combined with a flowable composite. J. dent. Res., v.78, p.306, 1999. Special issue. /Abstract n.1603/

130. MIYAZAKI, M. et al. Influence or thermal cycling on dentin bond strenght of twostep bonding systems. Amer. J. Dent., v.11, n.3, p.118-122, June. 1998.

131. MOMOI, Y. et al. Marginal leakage of composite under thermal stress by temperature. J.dent. Res., v.70, p.388, 1991. Special issue . /Abstract n.979/

132. MONDELLI,J. Proteção do complexo dentino pulpar. São Paulo, Artes médicas, 1998. 
133. MONDELLI, J. et al. Restaurações estéticas. 2 ed. São Paulo, Sarvier. 1987. Cap.3, p.55-65.

134. MONDELLI,J. Restaurações de resina composta em dentes posteriores: sim ou não? In: BOTTINO,M.A.; FELLER,C.,Coord. Atualização na clínica odontológica. São Paulo, Artes Médicas, 1992.p.91-114

135. MONDELLI,J. et al Procedimentos pré-clínicos. São Paulo, Premier, 1998.

136. MONDELLI, R.F.L. Resina composta em dentes posteriores.Maxiodonto: Dentística, v.1, n.3, p.1-58, maio/jun. 1995.

137. MUNKSGAARD, E.C.; IRIE, M. Effect of load-cycling on bond between composite fillings and dentin established by Gluma and various resins. Scand. J. dent. Res., v.96, n.6, p.579-83, 1988.

138. MUNKSGAARD, E.C.; HANSEN, E.K.; ASMUSSEN, E. Effect of filve adhesives on adaptation of resin in dentin cavities. Scand. J. dent. Res., v.92, n.6, p.544-48, Dec. 1984.

139. MUNKSGAARD, E.C.; ITOH, K.; JORGENSSEN, K.D. Dentin-polymer bond in resin fillings tested in vitro by thermo-and load-cycling .J. prosth. Dent., v.64, n.2 , p.144-6, Feb. 1985.

140. MOORE, D.S.; JOHNSON, W.W.; KAPLAN, I. A comparison of amalgam microleakage with a 4-META liner and copal varnish. Int. J.Prosth., v.8, n.5, p.461-6, Spt./Oct. 1995.

141. MURRAY, G.A.; YATES, J.L.; WILLIANS, J.I. Effect of 4 cavity varnish and a fluoride solution on microleakage of dental amalgam restorations. Oper. Dent., v.8, n.4, p.148-51, 1983. 
142. MOUNT, G.J.; PAPAGEORGIOU, A.; MAKINSON, O.F. Microleakage in the sandwich technique. Amer. J. Dent., v.5,n.4,p.195-8, Aug. 1992.

143. NAKABAYASHI, N. Resin reinforced dentin due to infiltration of monomers into the dentin at the adhesive interface. J.Japan Dent.Mat., v.1, p.78-81, 1992 apud SILVA E SOUZA JUNIOR, M.H. p.4.

144. NAKABAYASHI, N.; KOJIMA, K.; MASUHARA, E. The promotion of adhesion by the infiltration of monomers into tooth substrates. J. Biomed Mater Res,v.16,p.265-73, 1982.

145. NAKABAYASHI, N.; NAKAMURA, M.; YASUDA, N. Hybrid layer as a dentin bonding mechanism. J. Esthet. Dent., v.3, n.4, p.133-8, July/Aug. 1991.

146. NARA, Y., KATSUYAMA, S.; DOGON, I.L. Microleakage of composite retoration under thermocycling and simultaneous repeated load. J. dent. Res., v.70, p. 388, 1991. Special issue./Abstract n. 980/

147. NAVARRO, M.F.L.; PASCOTTO, R.C. Cimentos de ionômero de vidro. In:__ Cimentos de ionômero de vidro. São Paulo, Artes Médicas 1998. Cap.1, p.1-24.

148. OSBORNE, J. W.; GALE, E. N.; FERGUSON, G. W. One-year and two-year clinical evaluation of a composite resin x amalgam. J. prosthet. Dent., v.30, n.5, p.795800, Nov. 1973.

149. PACHECO, J.F.M.; CONCEIÇÃO, E.N.; SUFFERT, L.W. Associação ionômero de vidro-resina composta: influência na infiltração marginal de restaurações classe V. Rev. Fac. Odont. Porto Alegre. V.33, n.1, p.22-5, jul. 1992.

150. PALAGHIAS, G. Corrosion of dental amalgams in solutions of sodium sulfide and ammonia. Scand. J. dent. Res., v.94, n.3, p.274-80, 1986. 
151. PALMER, D.S.; BARCO, M.T.; BILLY, E.J. Temperature extremes produced orally by hot and cold liquids. J. prosth. Dent., v.67 , n.3, p.325-7, Mar. 1992.

152. PASHLEY, D.H. Clinical considerations of microleakage. J. endod., v.16, n.2, p.70-7, Feb. 1990.

153. PERDIGÃO, J. et al. In vitro bond strengths and SEM evaluation of dentin bonding systems to different dentin substrates. J. dent. Res., v.73, n.1, p.44-55, Jan. 1994.

154. PEREIRA, M.A. Avaliação da infiltração marginal em cavidades de classe II restauradas com dois tipos de resinas compostas. Efeito do carregamento oclusal e de técnicas de inserção. Bauru, 1999. 130p. Dissertação (Mestrado) Faculdade de Odontologia de Bauru, Univresidade de São Paulo.

155. PERETI NETO, J. Avaliação da deformação e da infiltração marginal das restaurações de resinas compostas em dentes posteriores, submetidas a força de compressão. Bauru, 1992. 109p. Tese (Doutorado) - Faculdade de Odontologia de Bauru, Universidade de São Paulo.

156. PHILLIPS, R. W. et al. One-year observations on a composite resin for class II restorations. J. prosthet. Dent., v. 26, n. 1, p.68-77, Jan. 1971.

157. PHILLIPS, R. W. et al. Observations on a composite resin for class II restorations: three-year report. J. prosthet. Dent., v. 30, n. 6, p. 891-7, Dec. 1973.

158. PICKARD, H.M.; GAYFORD, J.J. Leakage at margins of amalgam restorations. Brit. dent. J., v.119, n.2, p.69-80, July 1965. 
159. PIN, M.L.G. Avaliação da microinfiltração marginal em cavidades classe II modificadas, restauradas com cimentos de ionômero de vidro, convencional, modificados por resina e com uma resina composta modificada por poliácidos: Estudos In vitro. Bauru, 1997. 124p. Dissertação (Mestrado) - Faculdade de Odontologia de Bauru, Universidade de São Paulo.

160. POWELL, L.G.; DAINES, D.T. Solubility of cavity varnish: a study in vitro. Oper. Dent., v.12, n.2, p.48-52, Spring 1987.

161. PRATI, C. et al. Permeability and microleakage of class II resin composite restorations. J. Dent., v.22, n.1, p.49-56, Feb.1994.

162. QVIST, V. The effect of mastication on marginal adaptation of composite restorations in vivo. J. dent. Res., v.62, n.8, p.904-6, Aug. 1983.

163. RAADAL, M. Microleakage around preventive composite fillings in loaded teeth. Scand. J. dent. Res., v.87, n.5, p.390-4, May 1979.

164. REES, J.S.; JACOBSEN, P.H. The current status of composite material and adhesive systems. Restorat. Dent., v.6, n.4, p.4-8, Nov. 1990.

165. RETIEF, D.H. Are Adhesive techniques suficient to prevent microleakage? Oper. Dent., v.12, n.4, p.140-5, Autumn 1987.

166. RETIEF , D.H. Standardizing laboratory adhesion tests. Amer. J. Dent., v.4, n.5, p.231-236, Oct. 1991.

167. RETIEF, D.H. Do adhesives prevent microleakage? Int. dent. J., v.44, n.1, p.19-26, Feb. 1994.

168. RETIEF, D.H.; MANDRAS, R.S.; RUSSELL, C.M. Shear bond strength required to prevent microleakage at the dentin/restoration interface. Amer. J. Dent., v.7, n.1, p.43-6, Feb. 1994. 
169. RETIEF, D.H.; McCAGHREN, R.A.; RUSSEL, C.M. Microleakage of Vitrebond/P50 class II restorations. Amer. J. Dent., v.5, n.3, p.130-2, June 1992.

170. RIGSBY, D.F. et.al. Effect of axial load and temperature cycling on microleakage of resin restorations. Amer. J. Dent., v.5, n.3, p. 155-9, June 1992.

171. ROETERS, F.J.M.; OPDAM, N.J.M. Microleakage in box-type class II resin composite retorations. J. dent. Rest., v.74, p.427, 1995. Special issue./ Abstract n.210/

172. ROTH, F. Caracterísiticas de los compositos. In: Los compositos. Madrid, Masson, 1994. Cap.1, p.1-27.

173. RUEGGEBERG, F.A. Substrate for adhesion testing to tooth structure-review of the literature. Dent. Mater., v.7, n.1, p.2-10, Jan. 1991.

174. RUSSEL, R. R.; MAZER, R. B. Microleakage of class II restorations using a flowable composite as a liner. J. dent. Res., v.77, p.131, 1998. Special issue. /Abstract n.203/

175. RUYSTER, I.E.; ØYSAED, H. Composite for use in posterior teeth: composition and conversion. J. Biomed. Mater. Res., v.21, n.1, p.11-23, Jan. 1987.

176. SÁBIO, S.S. Avaliação da infiltração marginal de restaurações com resina composta em função do tipo de ativação. Bauru, 1996. 120p. Dissertação (Mestrado) - Faculdade de Odontologia de Bauru, Universidade de São Paulo.

177. SCHUCKAR, M.; GEURTSEN, W. Proximo-cervical adaptation of class II-composite restorations after thermocycling. J. dent. Res., v.75, p.40, 1996. Speciel issue. /Abstract n. 183/

178. SAKAGUCHI. R.L. et al. Effect of polimerization contraction in composite restorations. J. Dent., v.20, n.3, p.178-82, June 1992. 
179. SAUNDERS, W.P.; SAUNDERS, E.M. Microleakage of bonding agents with wet and dry bond techniques. Amer. J. Dent., v.9, n.1, p.34-6, Feb. 1996.

180. SHORTALL, A.C.; HARRINGTON, E. Guidelines for the selection, use, and maintenance of visible light activation units. Brit. Dent. J., v.181, n.10, p.383-387, Nov. 1996.

181. SIDHU, S.K.; HENDERSON, L.J. In vitro marginal leakage of cervical composite restorations lined with a light-cured glass ionomer. Oper. Dent., v.17, n.1, p.7-12, Jan./Feb. 1992.

182. SIDHU, S.K.; WATSON, T.F. Resin-modified glass ionomer materials - a status report for the American Journal of Dentistry. Amer. J. Dent., v.8, n.1, p.59-67, Feb. 1995.

183. SILVA E SOUZA JÚNIOR, M.H. et al. Avaliação da infiltração marginal em esmalte e cemento em cavidades de classe II MOD restauradas com cinco sistemas adesivos. Ver. Odont. Univ. São Paulo, v.5, n.2, p.140-5, jul./dez. 1991.

184. SILVA E SOUZA JUNIOR, M.H. da. Adesivos dentinários: evolução, estágio atual e considerações clínicas para sua utilização. Maxi-Odonto Dentística, v.1, n.1, p.118, jan./fev. 1995.

185. SJÖDIN, L.; UUSITALO, M.; VAN DIJKEN, J. Resin modified glass ionomer cements. In vitro microleakage in direct class $\mathrm{V}$ and class II sandwich restorations. Swed. dent. J., v.20, n.3, p.77-86, 1996.

186. STEWART, G.P.; BALDA, B.A.; NORMAN, R.D. The effects of mechanical loading on marginal integrity of composite restorations. Dent. Mater., v.2, n.4, p.151-2, Aug. 1986.

187. STRATMANN, R.G.; DONLY, K.J. Microleakage of class II silver glass ionomer/composite restorations. Amer. J. Dent., v.4, n.2, p.95-8, Apr. 1991. 
188. SUH, B. Composite shrinkage stress and its relaxation by the pulse cure technique (part 2). In: INTERNATIONAL SYMPOSIUM "RECONSTRUCTIONS WITH CARBON FIBER SYSTEM AND THE OPTIMUM ADHESIVE SYSTEM”, 2., S. Margherita Ligure, 1998. Proceedings. Milano, Hippocrates Edizioni Medico Scientificiche, 1998. p.26-32.

189. SWIFT JUNIOR, E.J. et al. Effect of low-viscosity resins on the performance of dental adhesives. Amer. J. Dent., v.9, n.3, p.100, June 1996.

190. TAYLOR, M.J.; LYNCH, E. Marginal adaptation. J. Dent., v.21, n.5, p.265-273, Oct./Nov. 1992.

191. TJAN, A.H.L.; DUNN, J.R. Microleakage at gingival dentin margins of class V composite restorations lined with light-cured glass ionomer cement. J. Amer. dent. Ass., v.121, n.6, p.706-710, Dec.1990.

192. TORSTENSON, B.; ODÉN, A. Effects of bonding agent types and incremental techniques on minimizing contraction gaps around resin composites. Dent. Mater., v.5, n.4, p.218-223, July. 1989.

193. TORSTENSEN, B.; BRÄNNSTRÖM, M. Contraction gap under composite resin restorations: effect of hygroscopic expansion and thermal stress. Oper. Dent., v.13, n.1, p.24-31, Jan./Feb. 1988.

194. TRUSHKOWSKY, R.D.; GWINNET, A.J. Microleakage of class V, composite, resin sandwich, and resin-modified glass ionomers. Amer. J. Dent., v.9, n.3, p.96-9, June 1996.

195. UNIVERSIDADE DE SÃO PAULO. Orientações básicas para apresentação de dissertações e teses na FOB-USP. /Apresentado Bauru, FOB-USP, 1991/ 
196. VAN MEERBEEK, B.; INOKOSHI, S.; BRAEM, M. et al. Morphological aspects of the resin-dent interdiffusion zone with different dentin adhesive systems. J. dent. Res., v.71, n.8, p.1530-40, Aug. 1992.

197. VERSLUIS, A.; TANTBIROJN, D.; DOUGLAS, W.H. Do dental composites always shrink toward the light? J. Dent. Res., v.77, n.6, p.1435-1445, June. 1998.

198. VIEIRA, L. C. C. Avaliação da infiltração marginal nas margens de esmalte e cemento em cavidades de classe II MOD restauradas com cinco sistemas adesivos. Bauru, 1988. 108p. Dissertação (Mestrado) - Faculdade de Odontologia de Bauru, Universidade de São Paulo.

199. WARREN JÚNIOR, J. A.; CLARK, N. P. Posterior composite resin: current trends in restorative techniques. Part 2: insertion, finishing and polishing. Gen. Dent., v.35, n.6, p.497-9, Nov./Dec. 1987.

200. WELSH, E.L.; HEMBREE, J.H. Microleakage at the gingival wall with four class V anterior restorative materials. J. prosth. Dent., v.54, n.3, p.370-2, Sept. 1985.

201. WENDT JR ., S.L.; McINNES, P.M.; DICKINSON, G.L. The effect or thermocycling in microleakage analysis. Dent. Mater., v.8, n.3, p.181-184, May. 1992.

202. WIECZKOWSKI, G. et al. Leakage patterns associated with glass-ionomer-based resin restorations. Oper. Dent., v.17,n.1,p.21-5,Jan./Feb. 1992.

203. WILSON, A.D.; KENT, B.E. A new translucent cement for dentistry. The glass ionomer cement. Brit. dent. J., v.132, n.4, p.133-5, Feb. 1972.

204. WRIGHT, W. et al. Effects of cavity varnish on clinical microleakage of amalgam. J. dent. Res., v.67, p.308, 1988./ Abstract n.1561/ 
205. WRIGHT, W. et al. Clinical microleakage evaluation a cavity varnish. Amer. J. Dent., v.5, n.3, p.3, p.263-5, Oct. 1992.

206. YAMAUTI, M. Avaliação da infiltração marginal em restaurações de resina composta empregando-se diferentes técnicas de inserção e de ativação da polimerização do material. Bauru, 1999. 141p. Dissertação (Mestrado) Faculdade de Odontologia de Bauru, Universidade de São Paulo.

207. YAP , A.U.J.; LIM, C.C.; NEO, J.C.L Marginal sealing ability of three cervical restorative systems . Quintessence Int., v.26, n.11, p.817-820, Nov. 1995.

208. YEARN, J.A. Factors affecting cure of visible light activated composites. Int. dent. J., v.35, n.3, p.218-225, Sep. 1985.

209. YOSHIKAWA, T. et al. Effects of dentin depth and cavity configuration on bond strength. J. dent. Res., v.78, n.4, p.898-905, Apr. 1999.

210. YOSHIKAWA, T. et al. Relationship between light curing method for reducing stress and C-fator. J. dent. Res., v.78, p.443, 1999. Special issue. /Abstract n.2703/

211. ZANATA, R.L. et al. Marginal leakage of restorations using combinations of glass ionomer and composite. J. dent. Res., v.74, n.3, p.492, Mar. 1995. Special issue./Abstract n. 729/ 
ABSTRACT 


\section{ABSTRACT}

Marginal leakage is one of the clinical problems associated with posterior composite resin. Some clinics alternatives has been suggest, in attempt for reduce the defective of this material, specific in cementum cavities extended, where this problems could be increased. The aim of this study was to evaluated the marginal sealing effectiveness of different materials applied at the cervical third of class II cavities in association with composite resin (sandwich technique). Microleakage at the cement/material interface was measured. M.O.D. cavities with cervical margin extended below the cement-enamel-junction was made at 60 human non carie premolars, that was distributed in groups of 10 elements, ending up at 5 groups as follow:

Control group - at each tooth, Scotchbond MP / Z-100

Group 1 - Scotchbond MP (Concise) / Concise / Scotchbond MP Z-100

Group 2 - Alpha Bond / Natural Flow / Scotchbond MP Z-100

Group 3 - One step / Aeliteflo / Scotchbond MP Z-100

Group 4 - Prime \& Bond 2.1 / Dyract-AP / Scotchbond MP Z-100

Group 5 - Verniz copalite / Velvalloy / Scotchbond MP Z-100

Before the teeth were prepared and restored with the various materials, the apex were sealed with Scotchbond MP Z-100. After 48 hours the restorations were polished with SofLex and were submitted to the mechanical cycling for 200 cycles of alternated loads, from 1 up to $17 \mathrm{~kg}$. Than the teeth were stored in distilled water at $37^{\circ} \mathrm{C}$ for 24 hours. After this the teeth were termocycled in a $2 \%$ methylene blue solution, corresponding to 180 cycles of 45 seconds each, at the temperatures of $5^{\circ} \mathrm{C}, 37^{\circ} \mathrm{C}, 55^{\circ} \mathrm{C}$. The specimens were stored again in 
methylene blue solution for 24 hours at $37{ }^{\circ} \mathrm{C}$. After this period, the teeth were embedded in acrylic bases and sectioned for the evaluation of the infiltration. Microleakage was determined by a qualitative analysis as showed the following conclusions:

- The Velvalloy amalgam and the composite resin Z-100 used as the control group showed, respectively, the worst rates of the marginal leakage at the cement/restorative material margin.

- There is statically significant between Dyract - AP and the others tested materials that showed lower rates of marginal microleakage.

- Concise, Aeliteflo and Natural Flow resins has a medium position in the microleakage ranking, with the same statically performance, and, unfavorable when compared to Dyract-AP; although, it was better than the amalgam.

- Although the Dyract-AP has the better performance, none of the testing materials avoid $100 \%$ microleakage at cervical margins in cementum. 